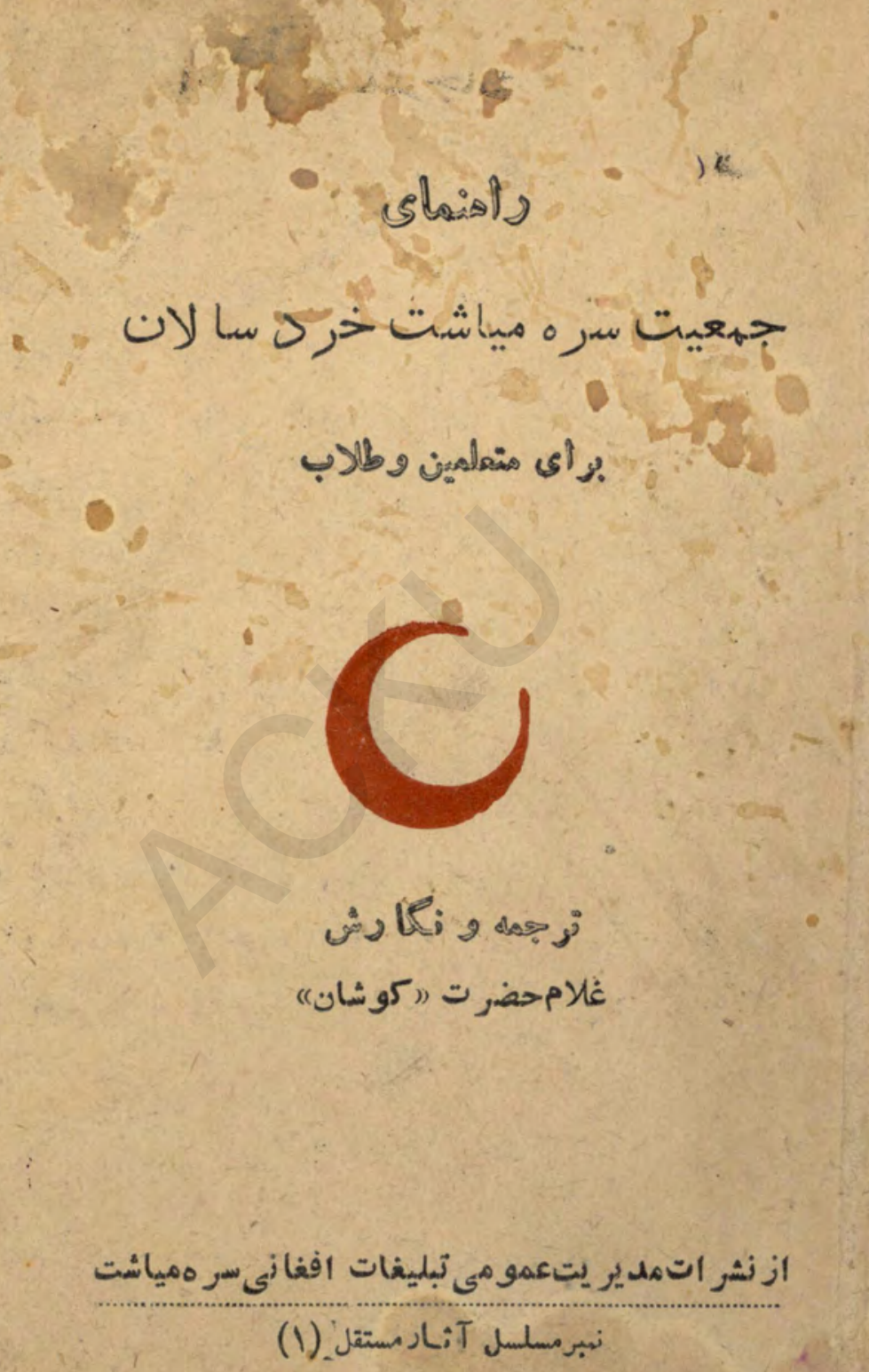

AFGHANISTAN CENTRE AT KABUL UNIVERSITY AFGHANISTAN CENTRE AT KABUL UNIVEASTY 


\section{زهرستمندرجات ,}

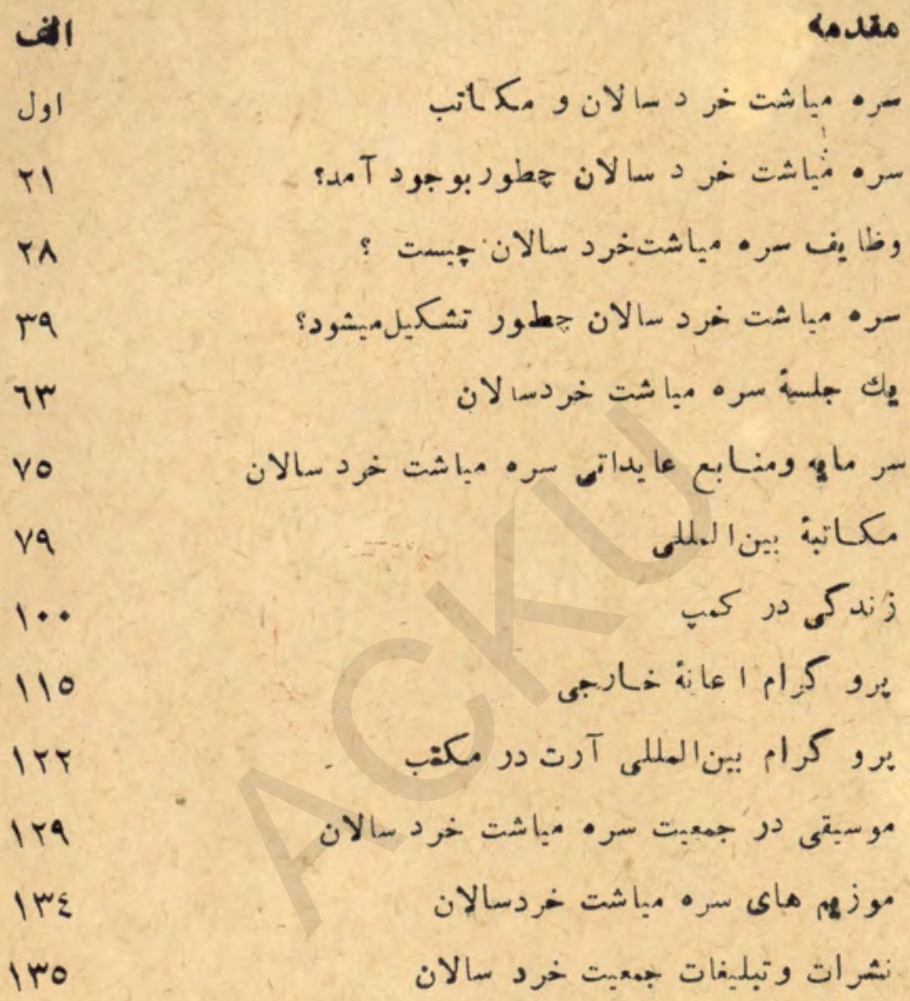

حق طبح هـحفو ظا است 


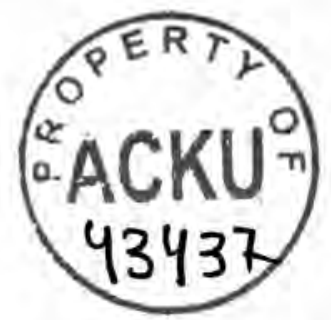

.

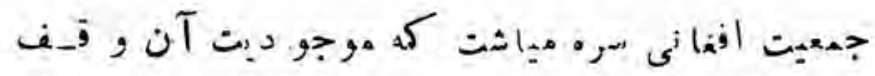

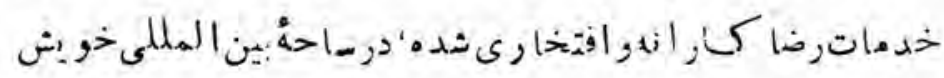

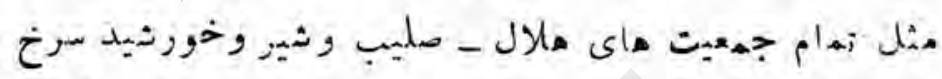

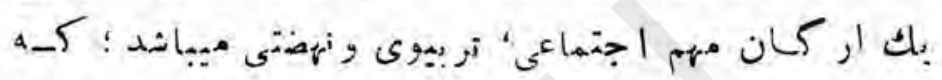

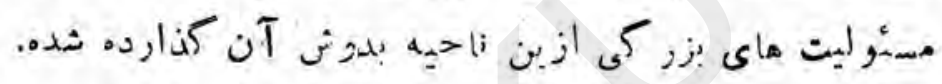

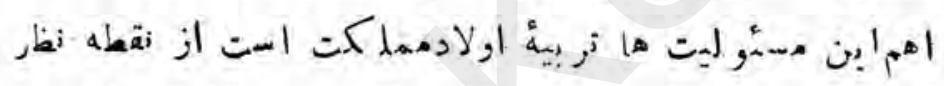

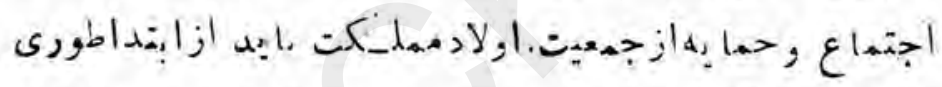

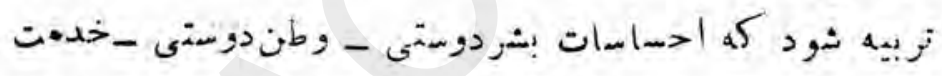

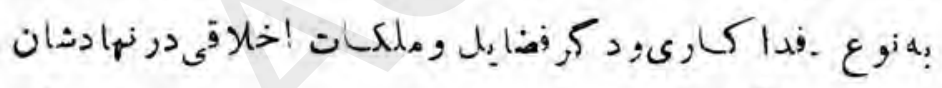

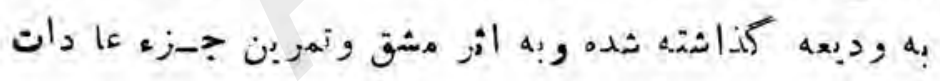

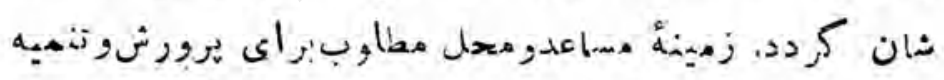

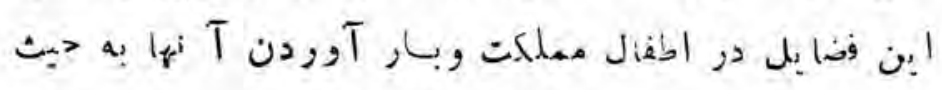

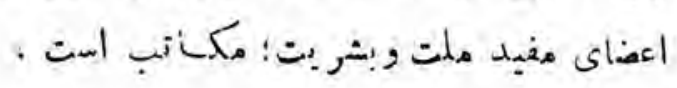

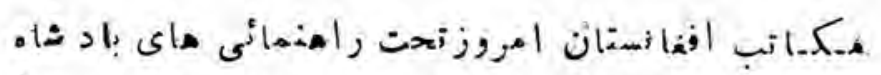

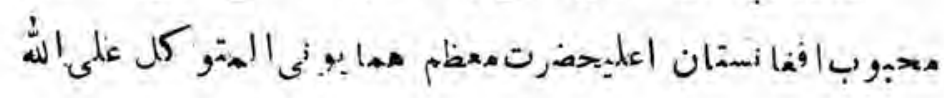


(ب)

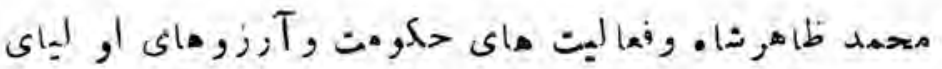

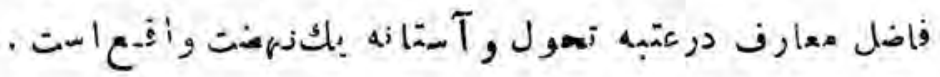

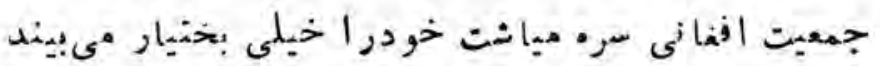

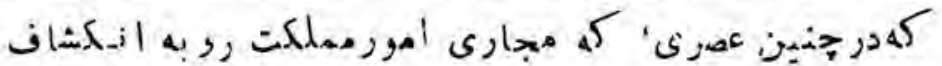

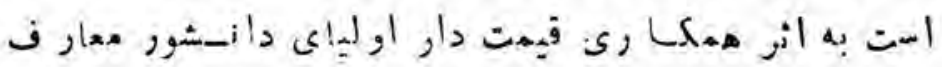

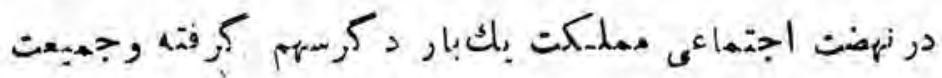

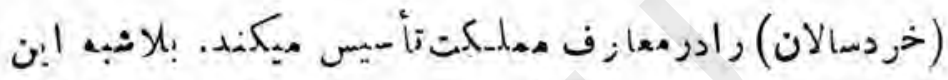

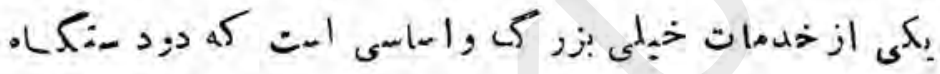

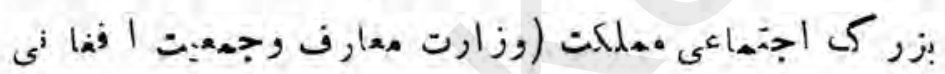

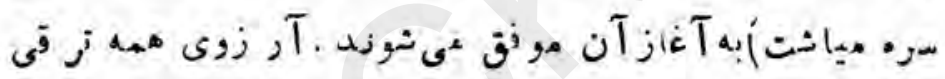

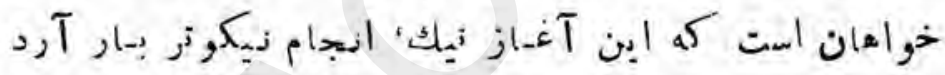

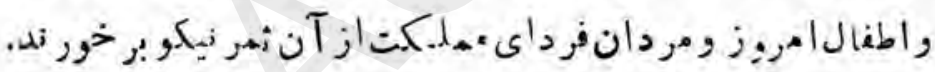

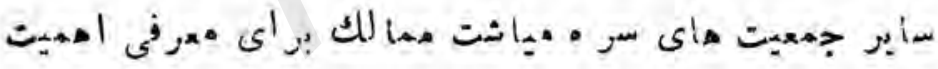

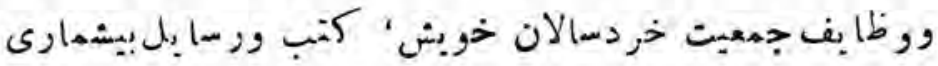

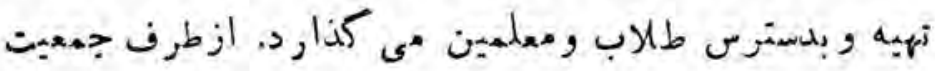

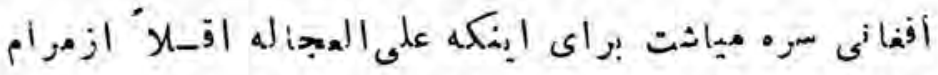

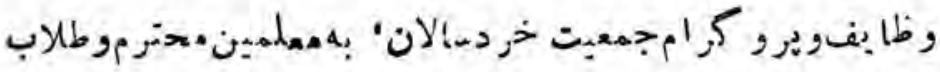

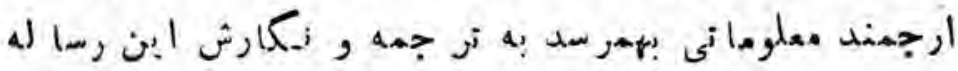


(飞)

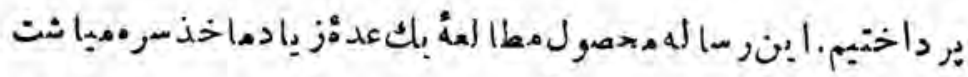

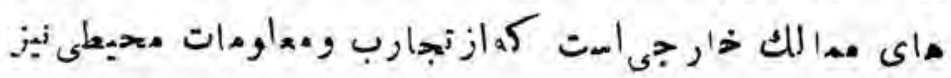

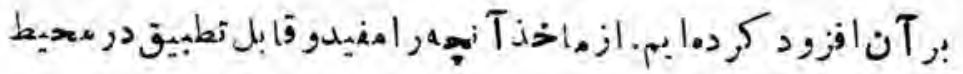

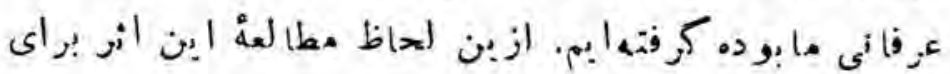

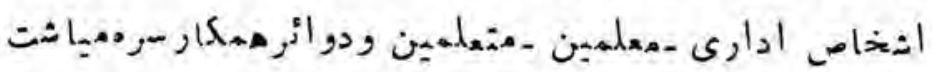

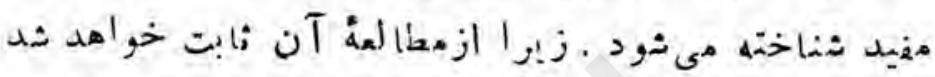

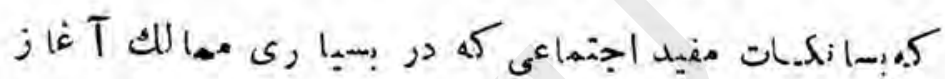

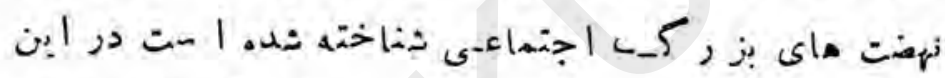

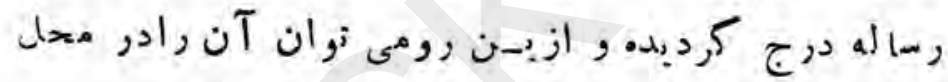

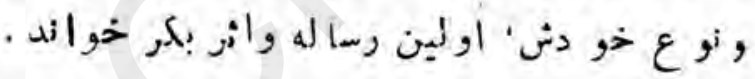

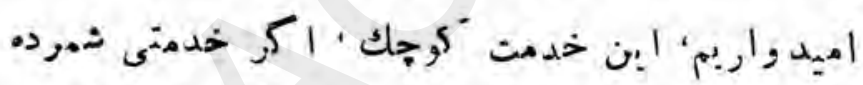

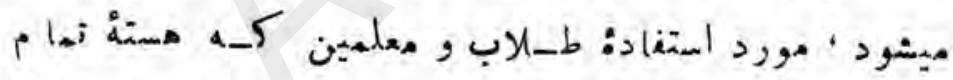

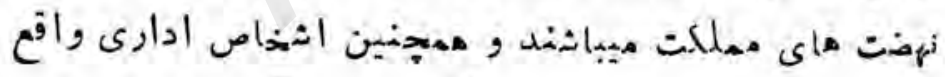

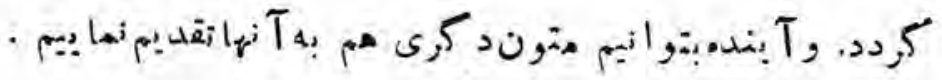

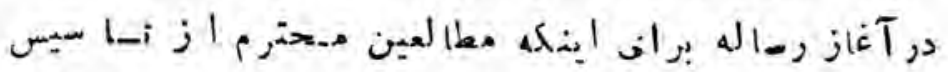

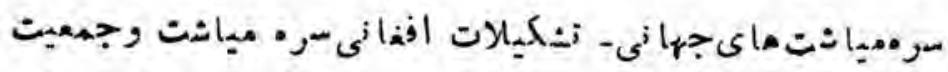

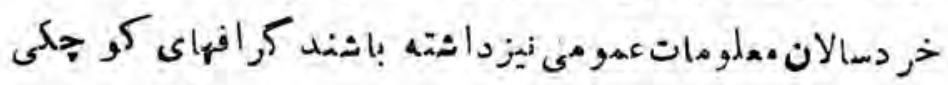

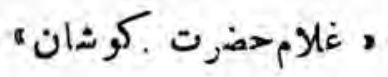
•.jon 


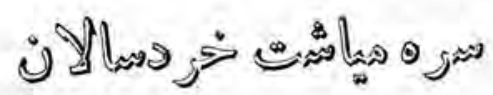

2

مكآتب

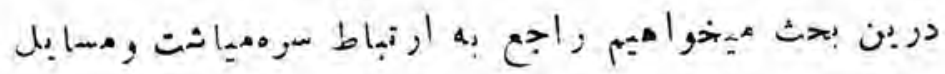

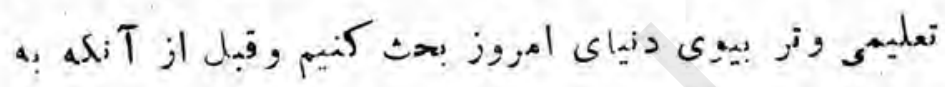

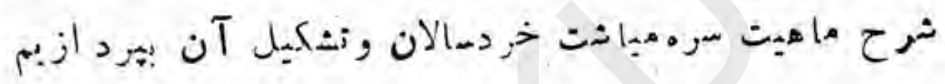

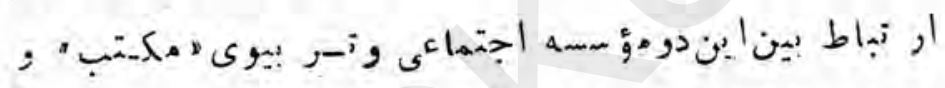

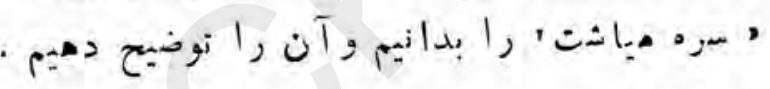

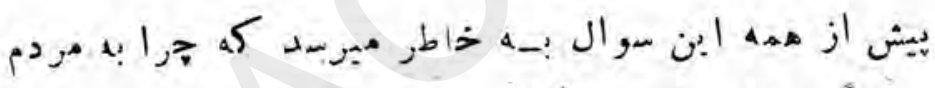

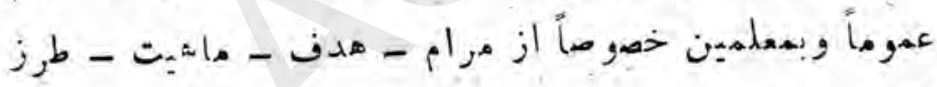

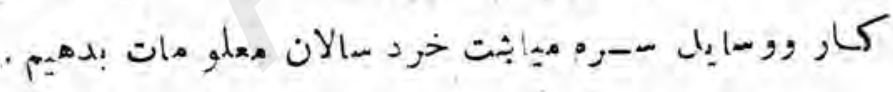

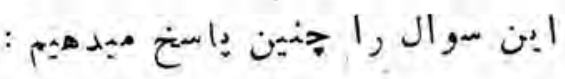

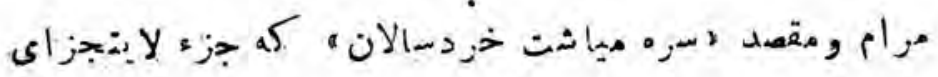

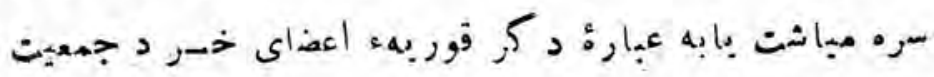

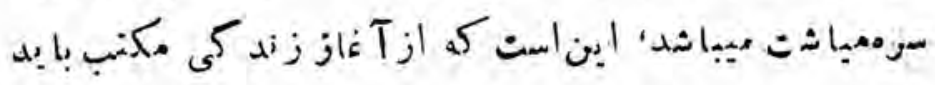

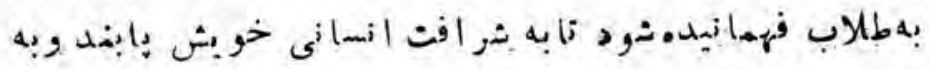


(r)

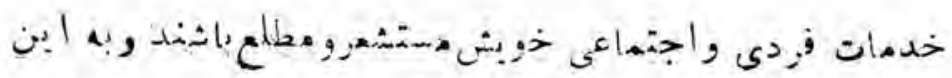

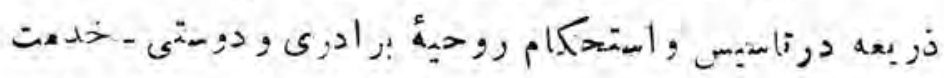

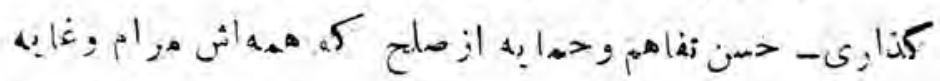

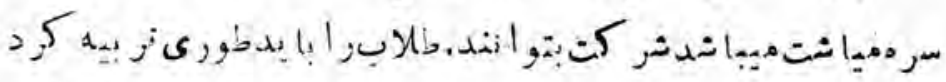

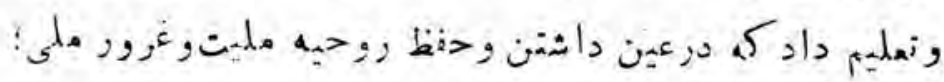

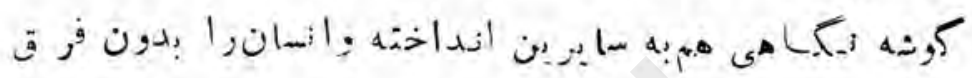

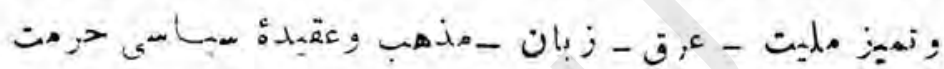
. $2,1 \lambda_{\lambda-\text {. }}$

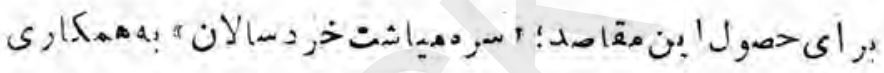
; . أ

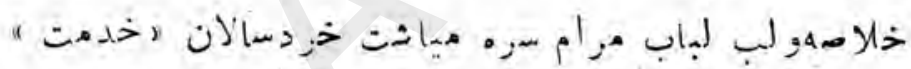

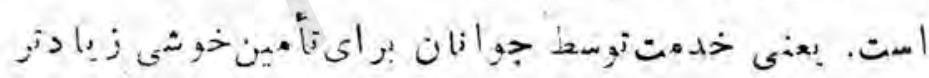

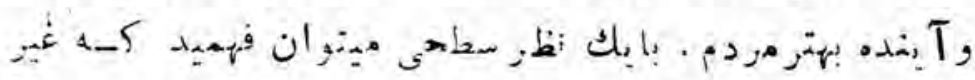

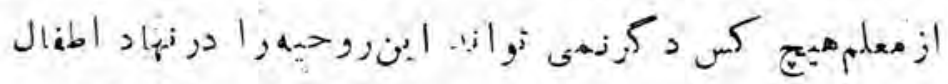

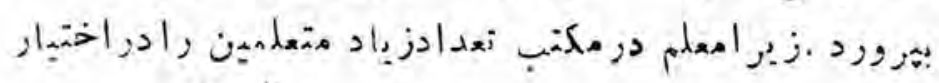

$$
\text { . } 2,1,2,
$$

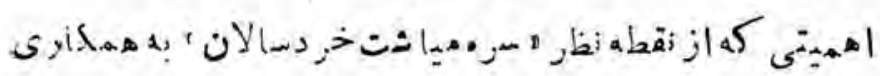


(r)

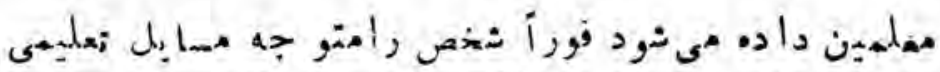

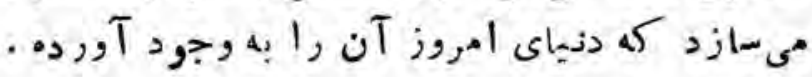

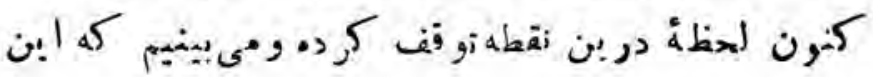

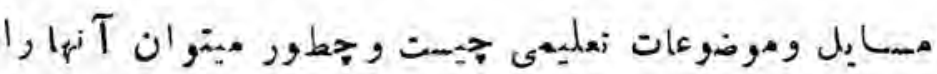
ازحيث اهـيت وضرورت دوجه بندى كرد هون

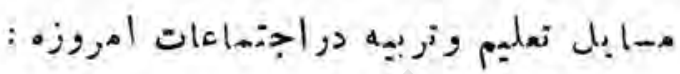

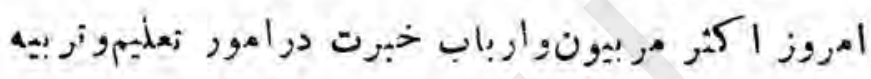

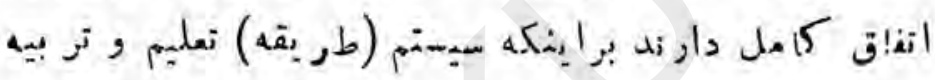

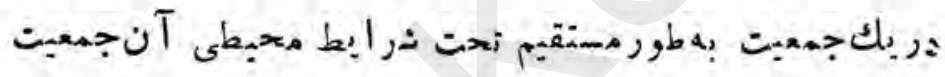

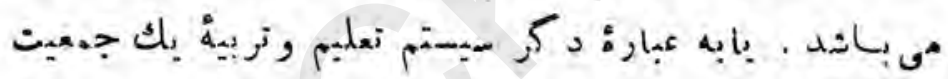

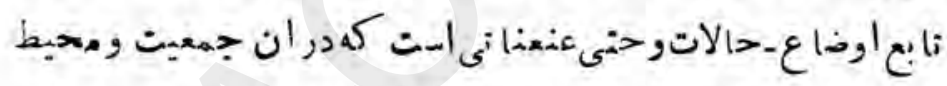

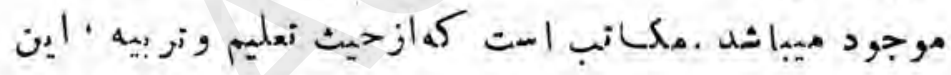

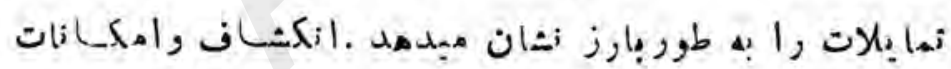

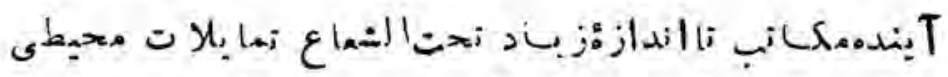

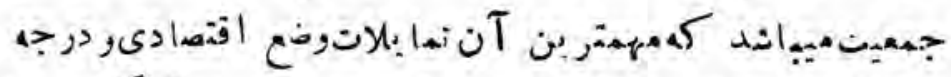

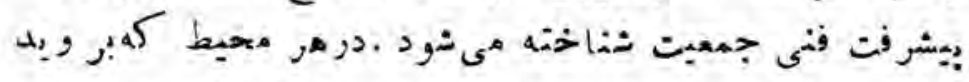

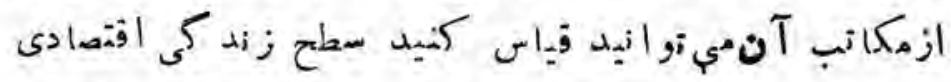

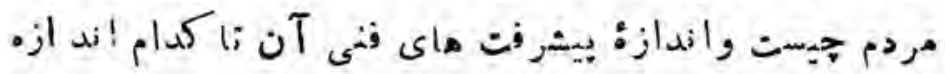

هي هرد 


\section{(z)}

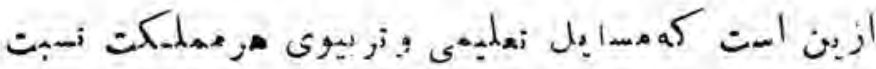

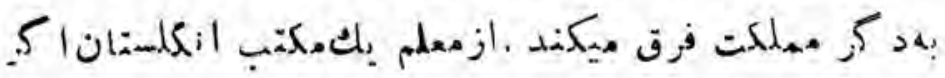

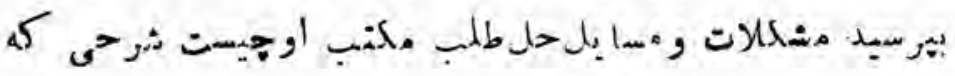

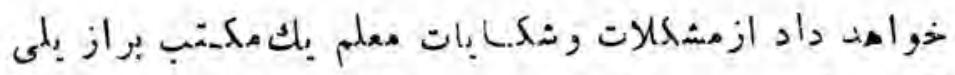

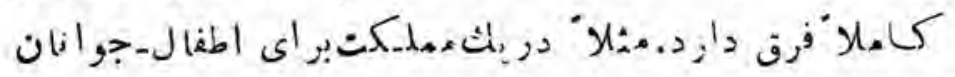

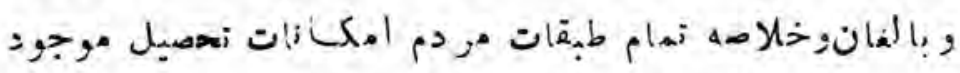

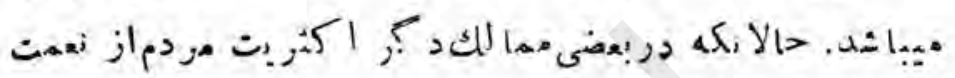

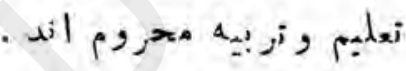

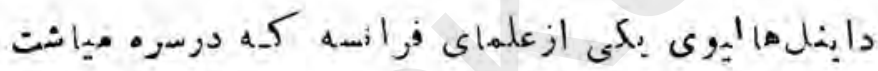

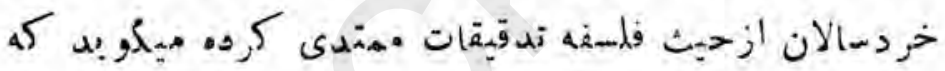

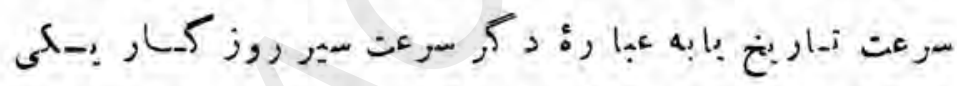

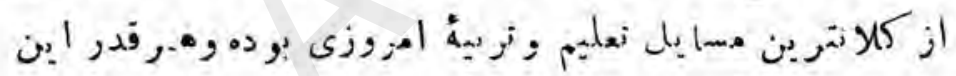

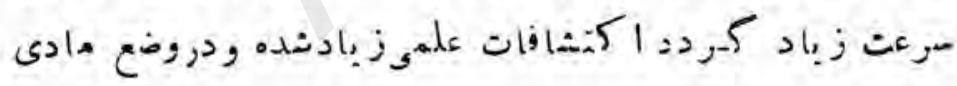

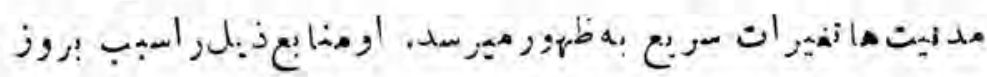

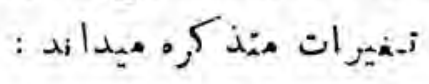

- 1

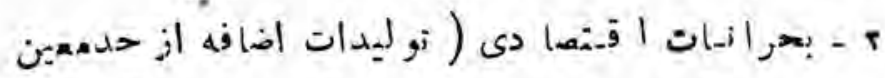

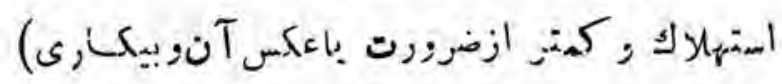


(o)

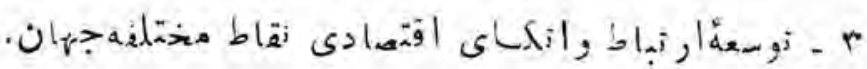

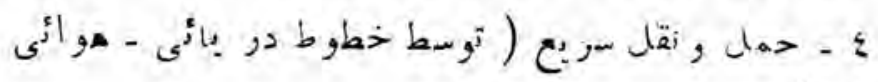

( )

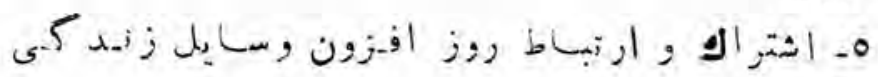

(0.

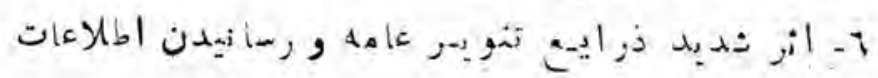

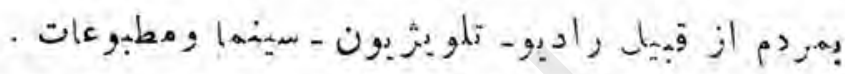

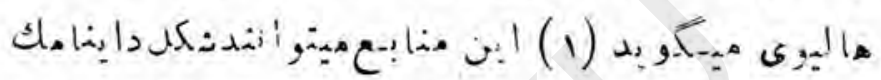

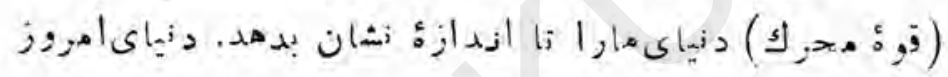

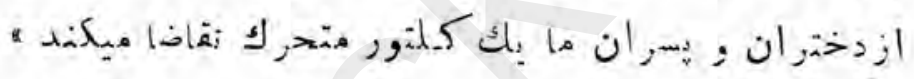

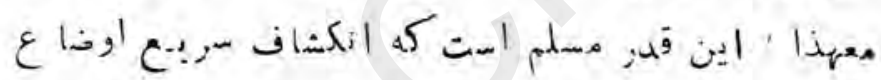

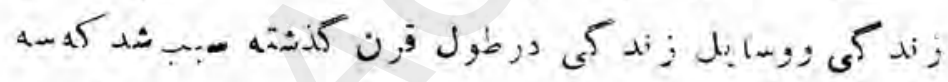

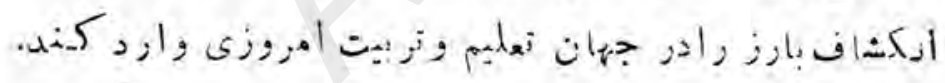

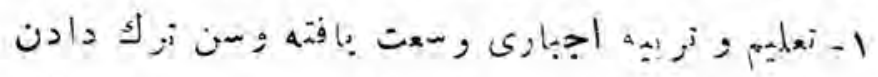

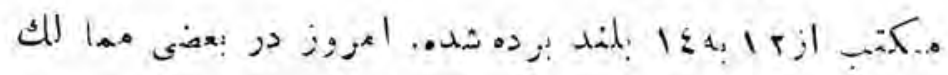

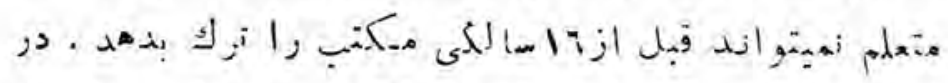

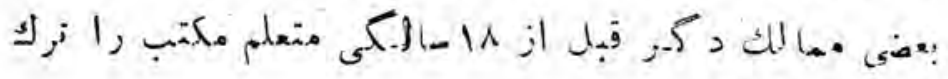

.

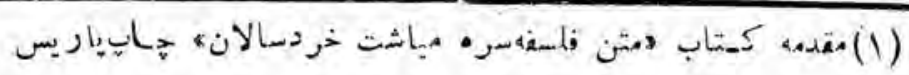


(1)

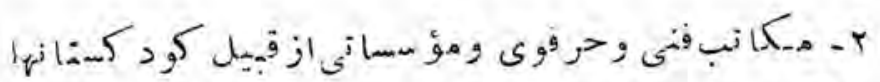

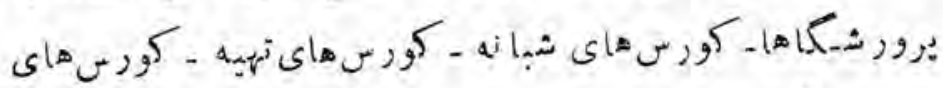

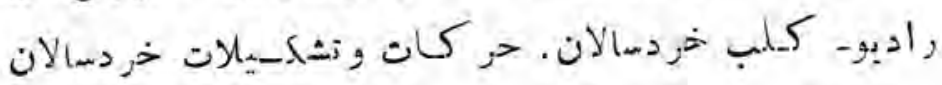

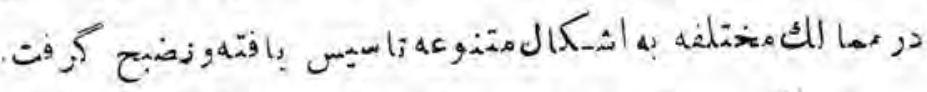

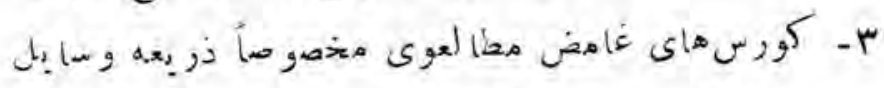

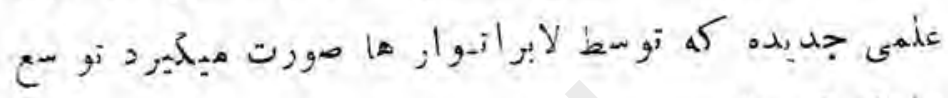
,

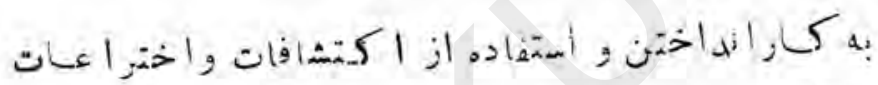

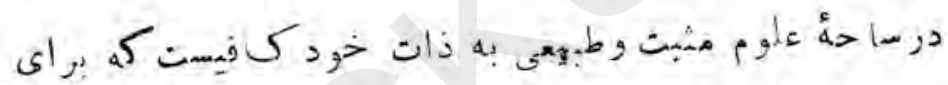

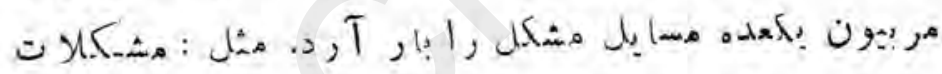

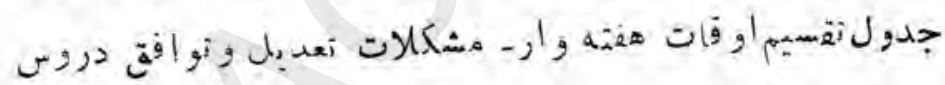

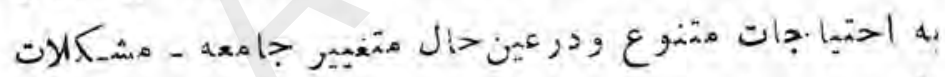

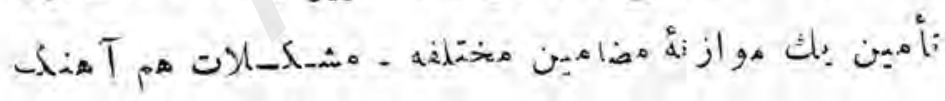

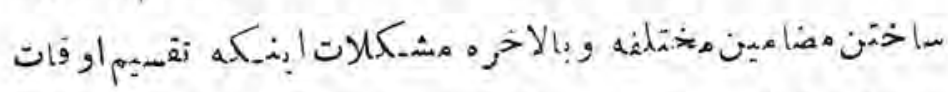

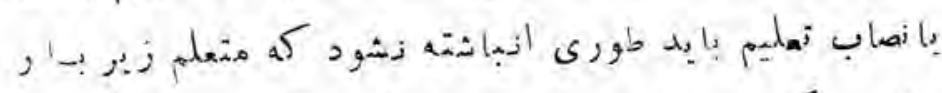

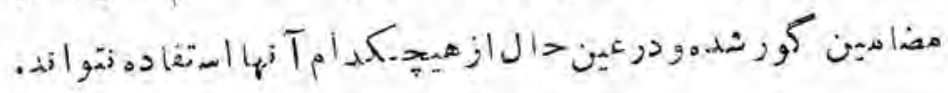

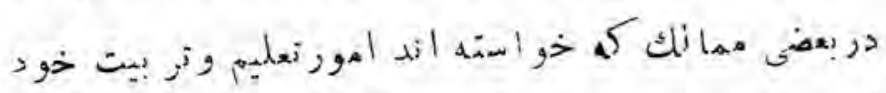

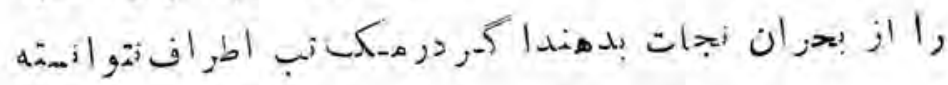


(v)

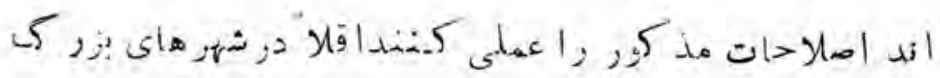

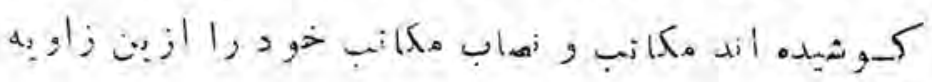

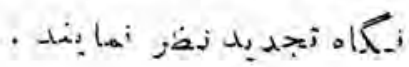

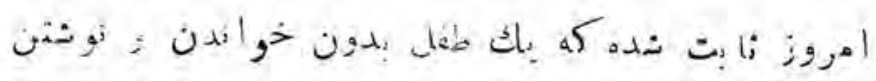

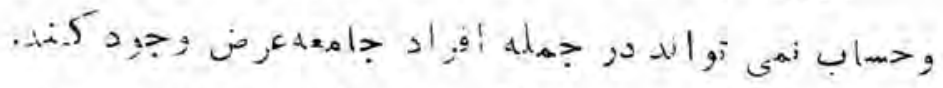

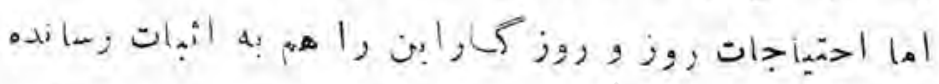

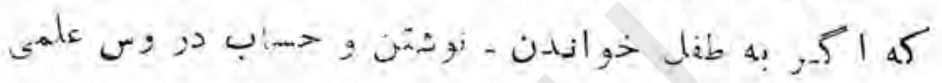

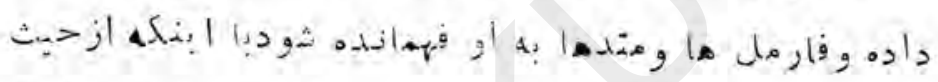

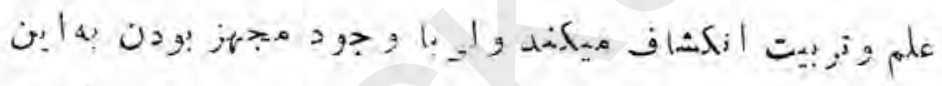

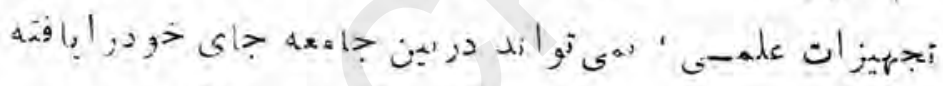

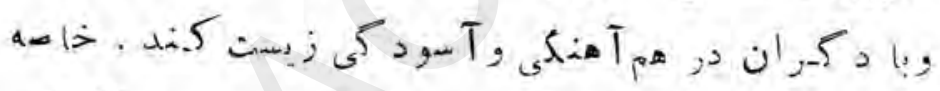

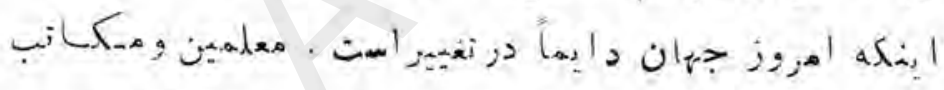

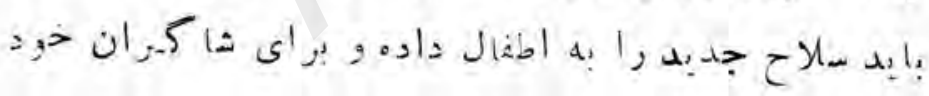

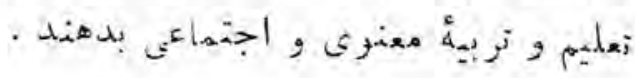

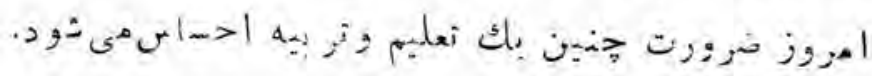

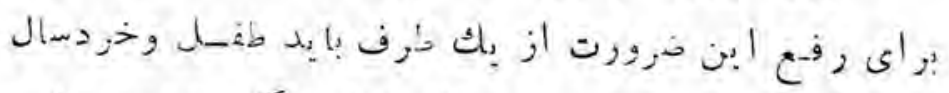

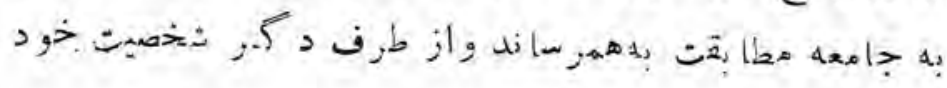

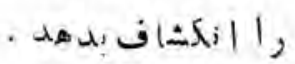


(^)

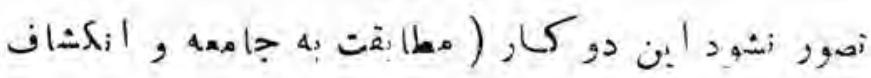

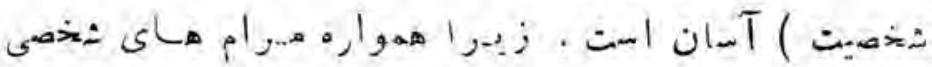

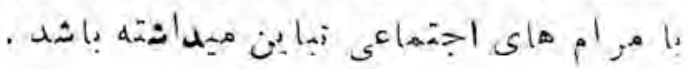

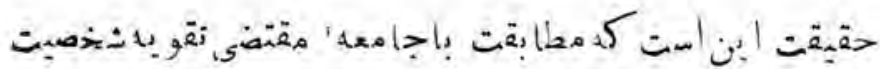

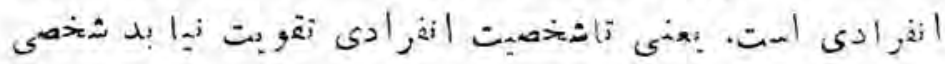

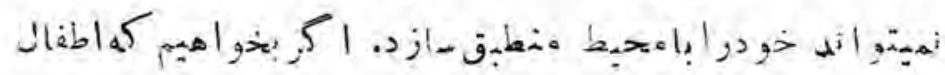

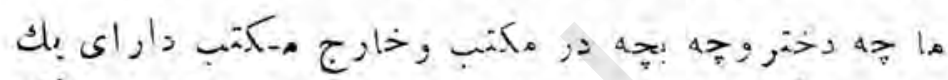

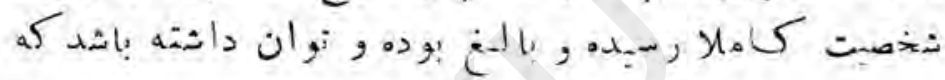

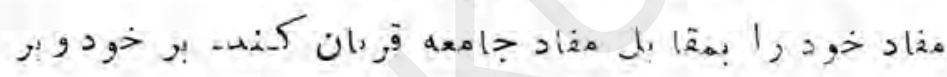

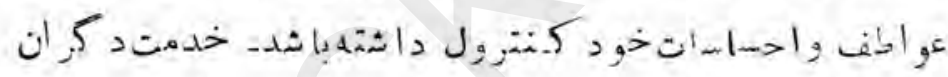

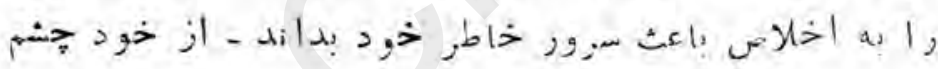

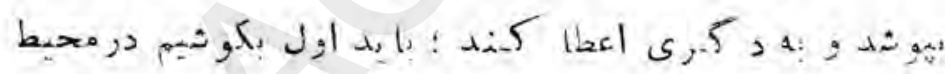

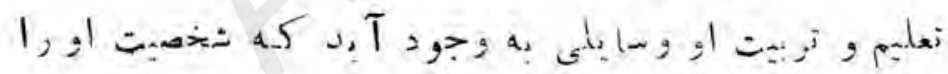

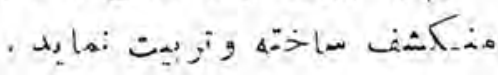

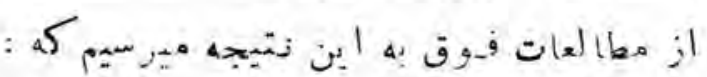

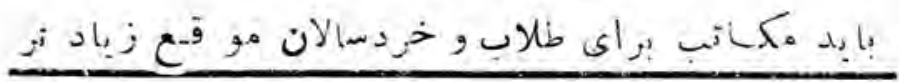

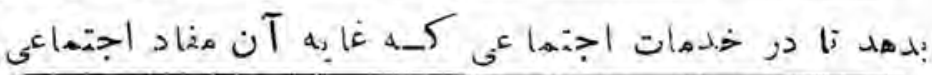

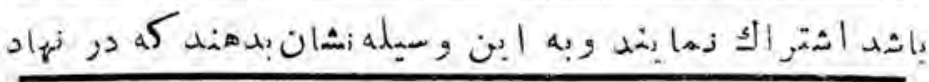

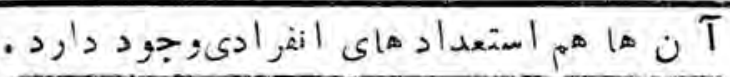


(a)

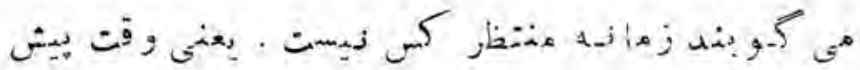

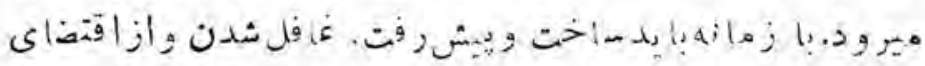

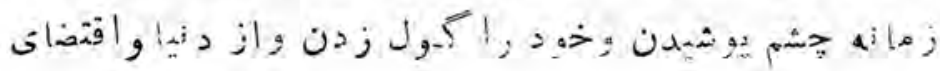

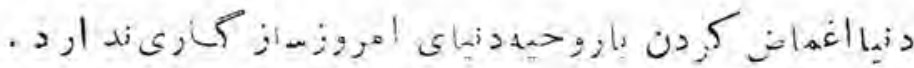

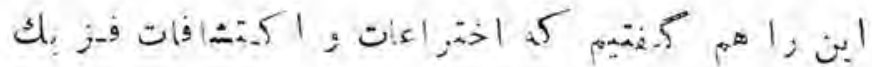

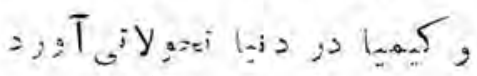

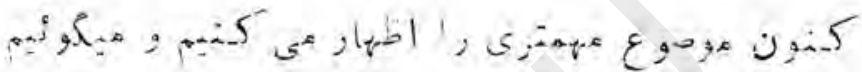

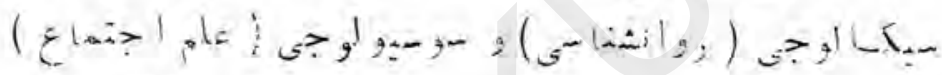

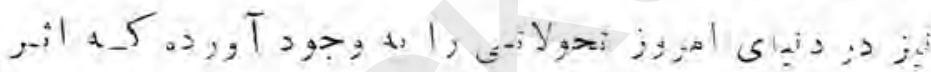

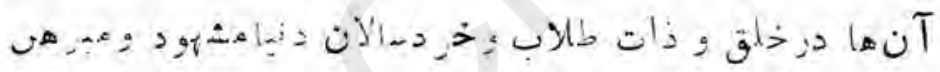

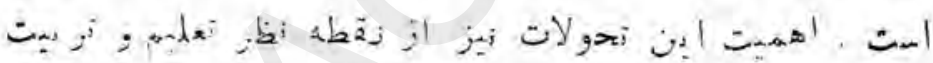

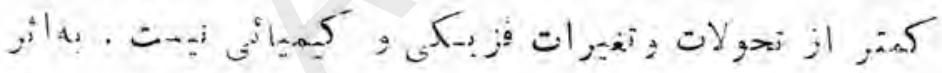

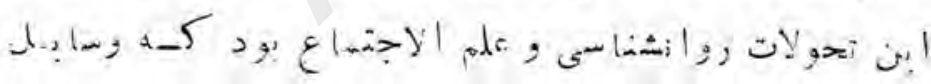

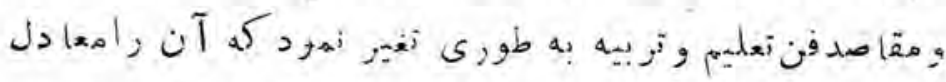

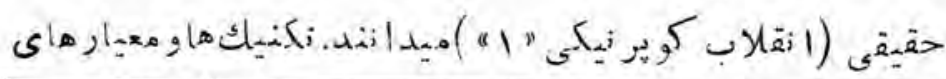

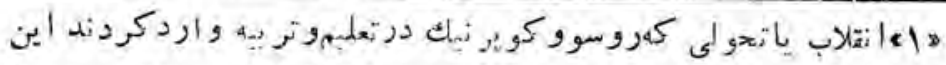

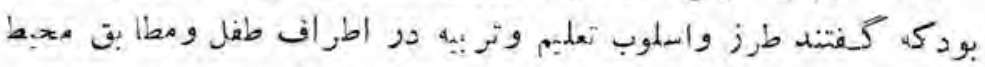

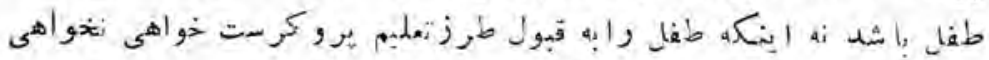

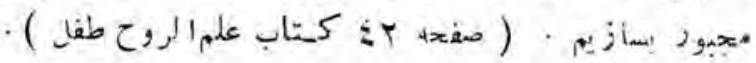


(1.)

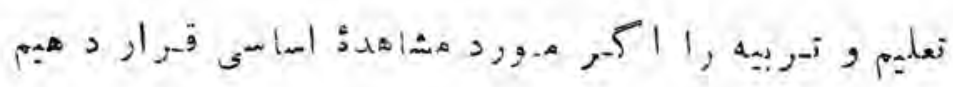
مى بsis

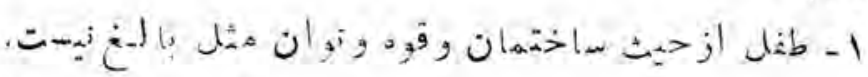

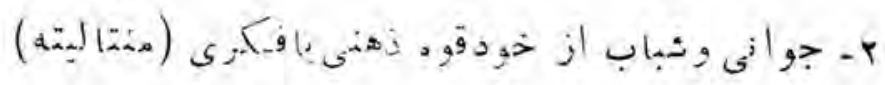

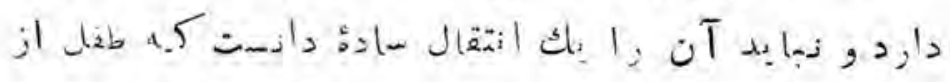

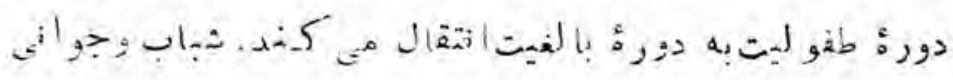

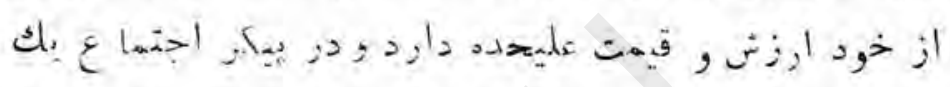

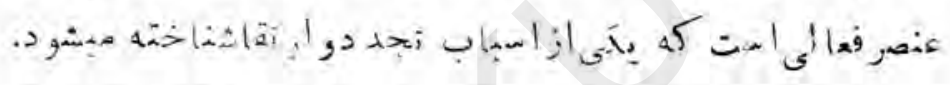

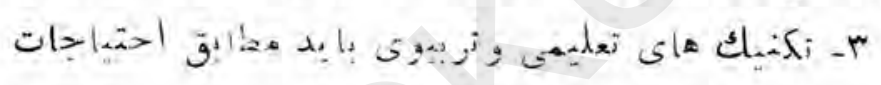

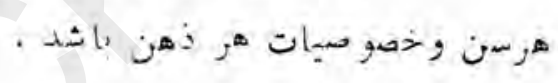

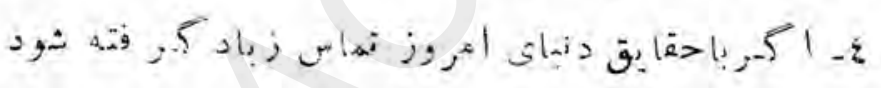

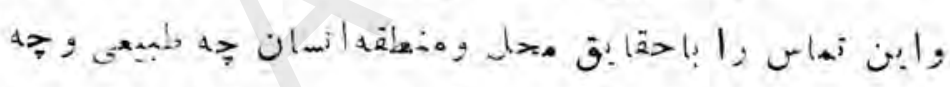

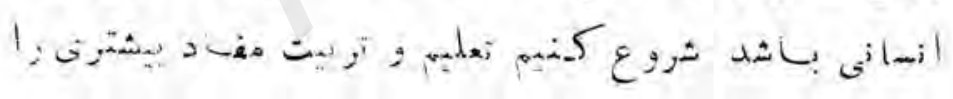

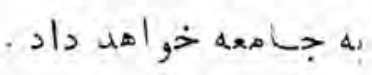

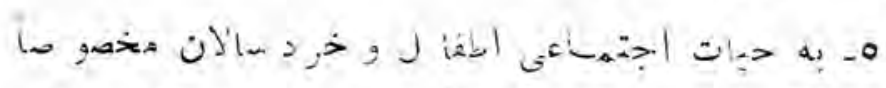

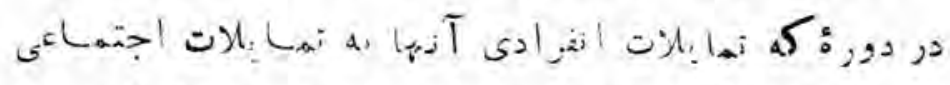

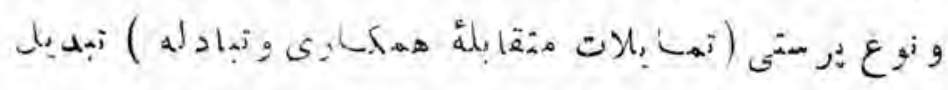

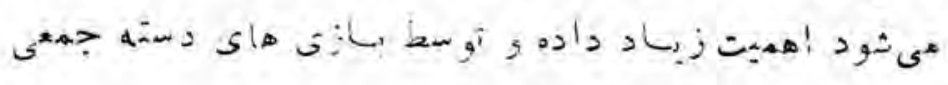


(11)

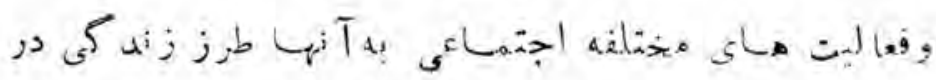

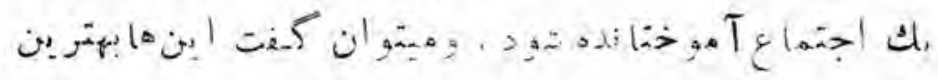

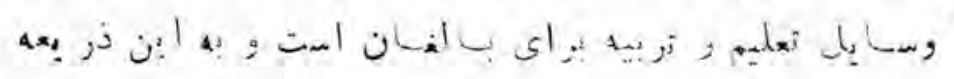
• . 42,5 is $1>,>1$.

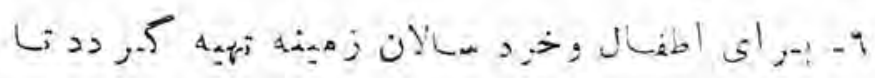
降

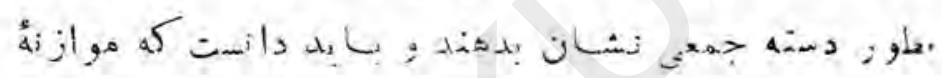

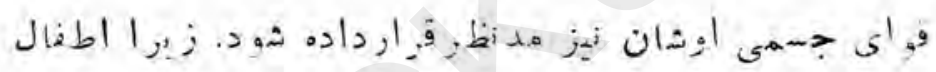

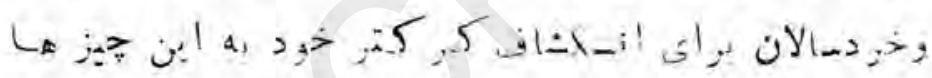
定

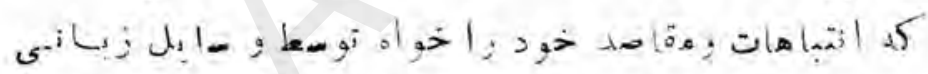

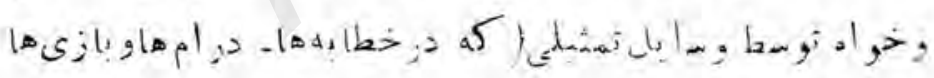
. . .

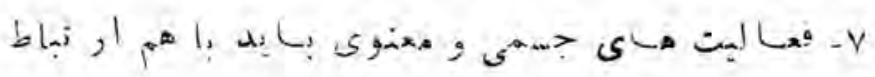
اثشه :ماشني:

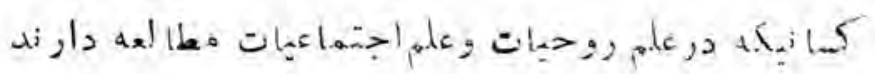
: 
(1r)

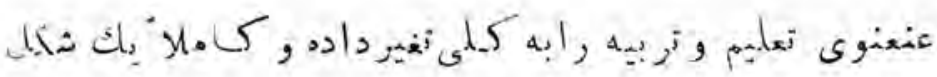

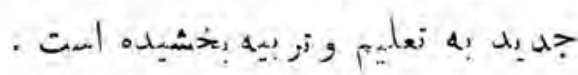

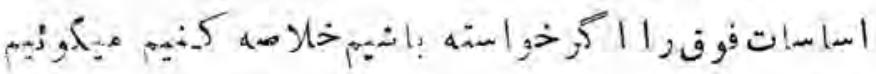

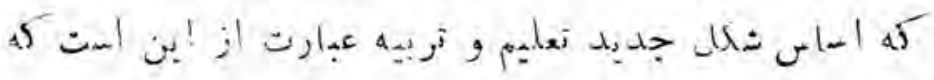

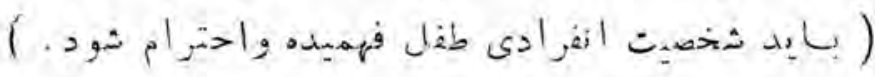

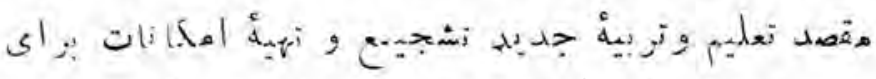

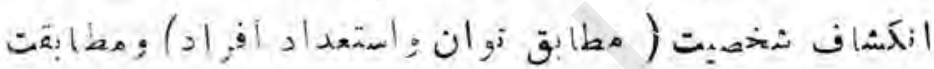

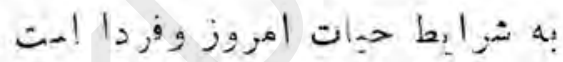

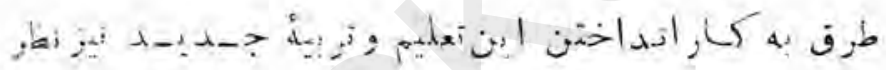

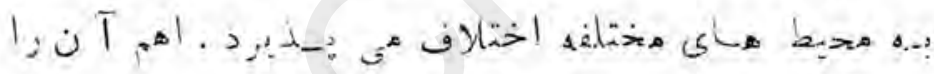

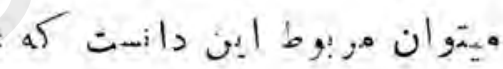

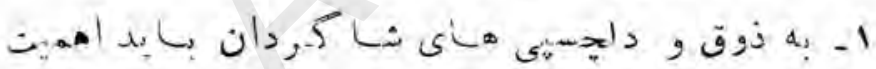

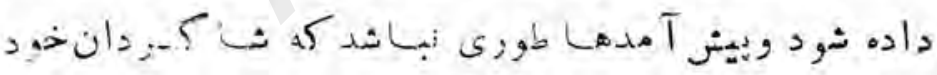

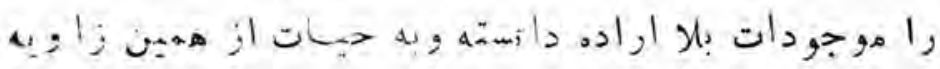

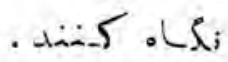

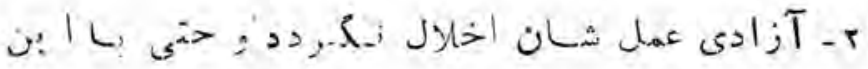

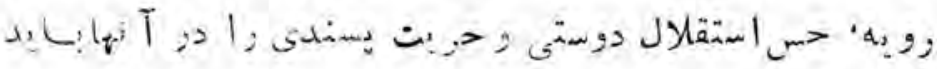

ploi tarit, 
(ir)

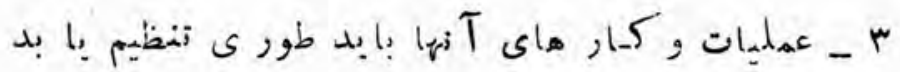

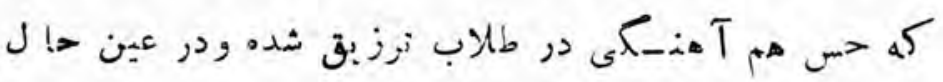

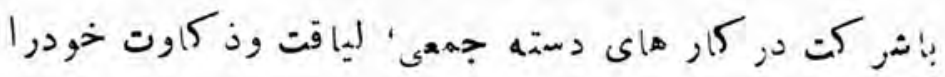

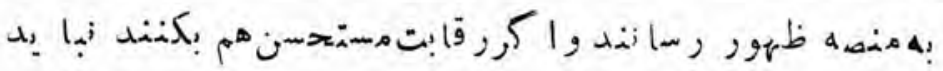

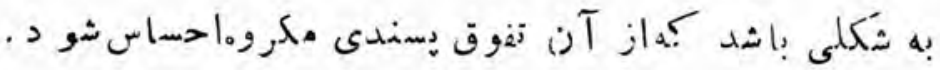

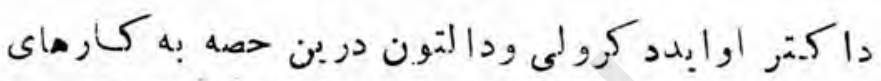

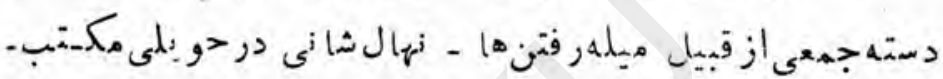

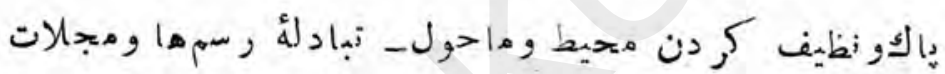

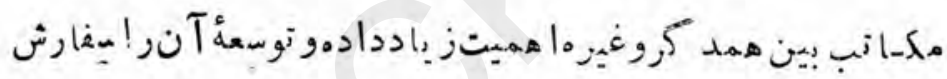

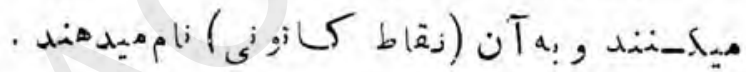

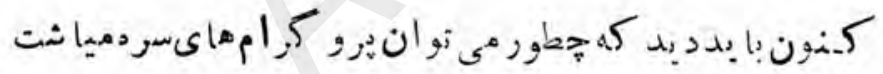

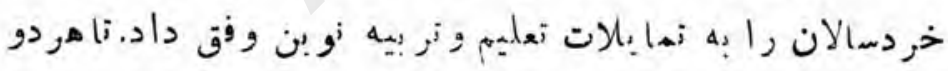

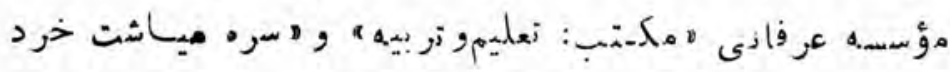

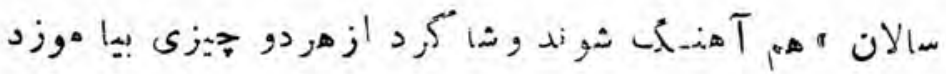

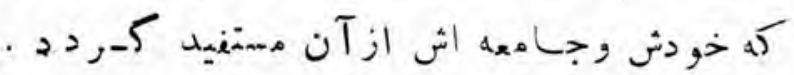

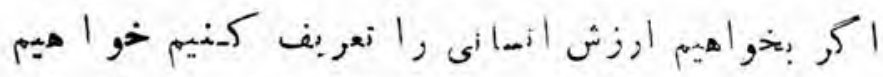

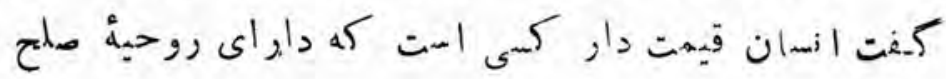


(iz)

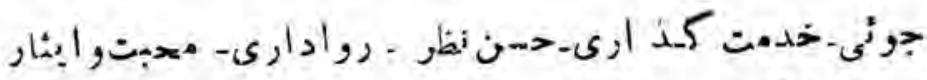

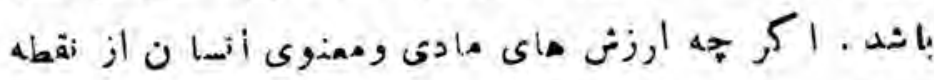

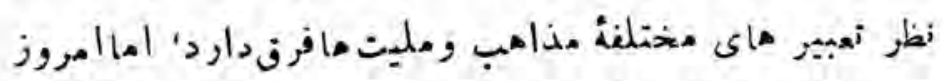

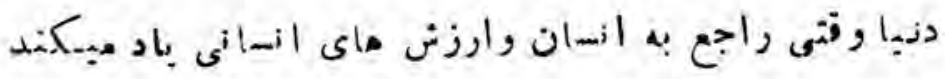

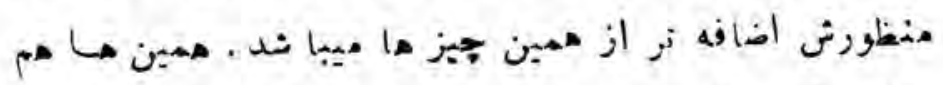

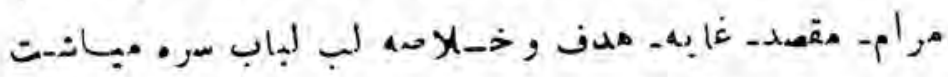

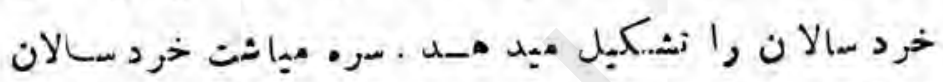

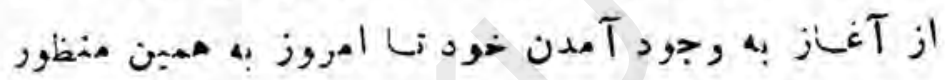

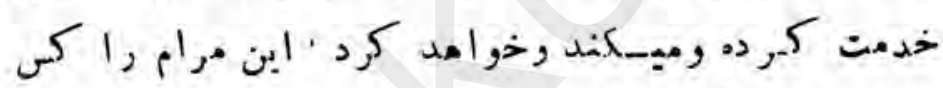

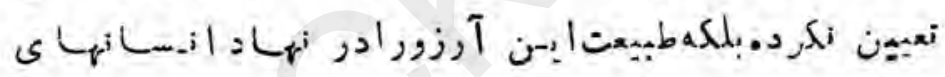

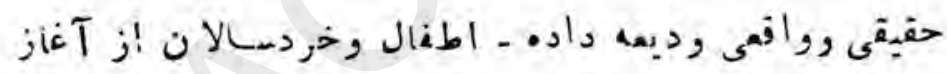

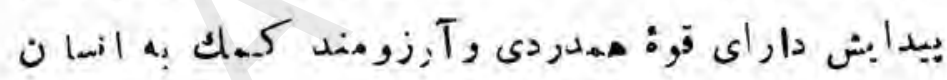

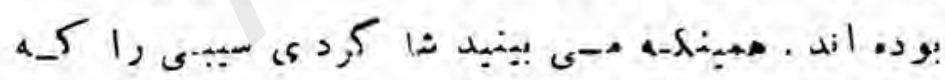

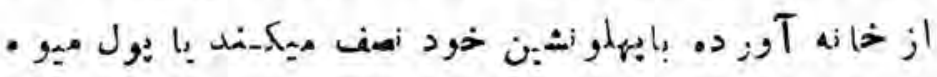

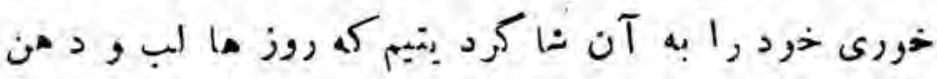

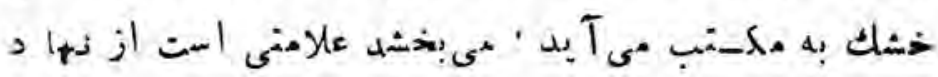

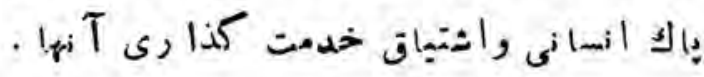

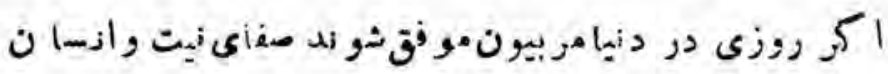


$(10)$

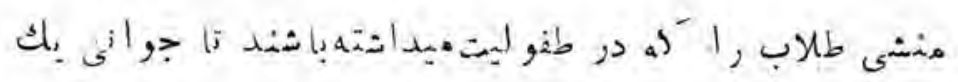

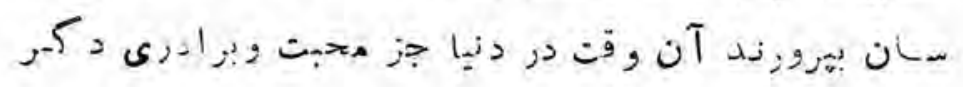

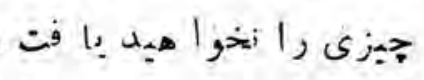

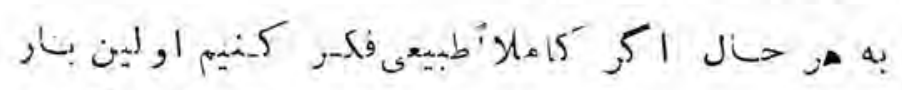

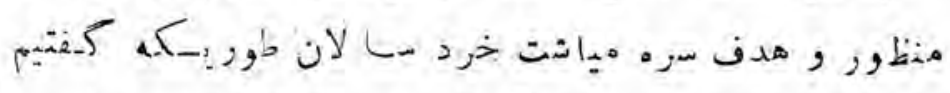

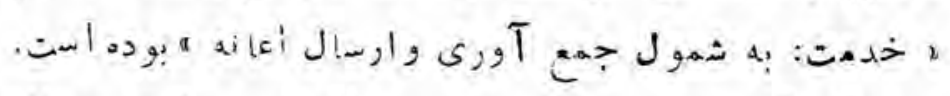

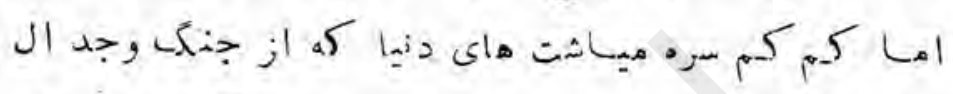

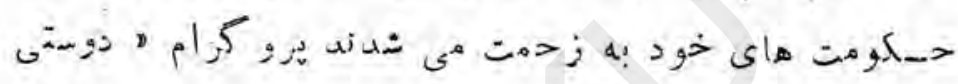

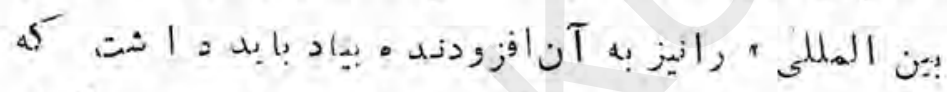

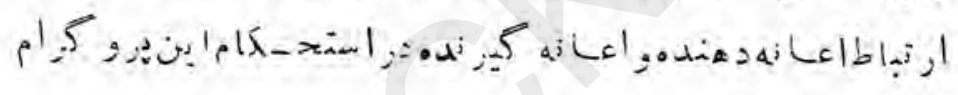

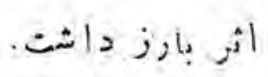

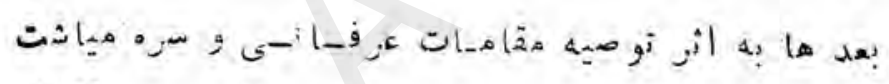

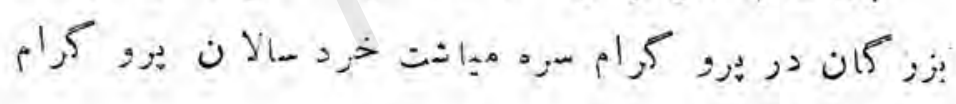

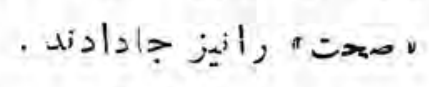

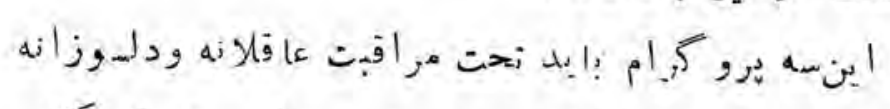

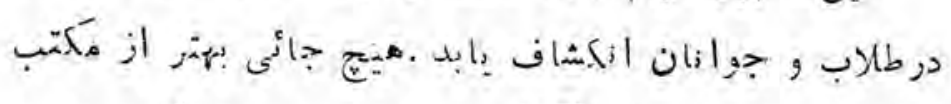

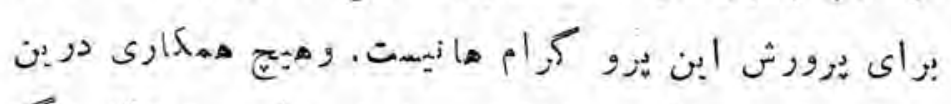

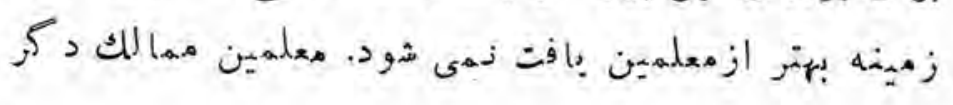




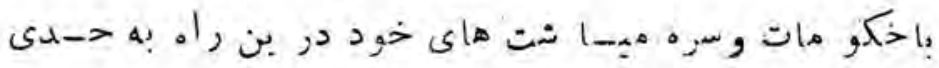

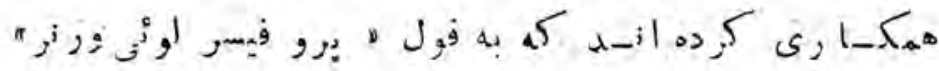

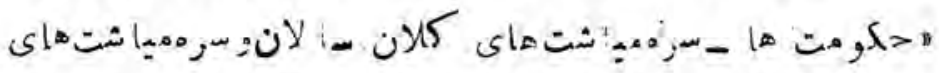

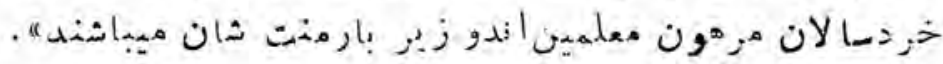

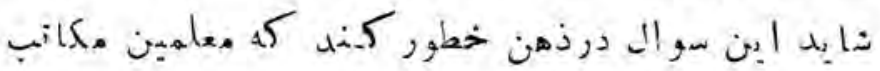

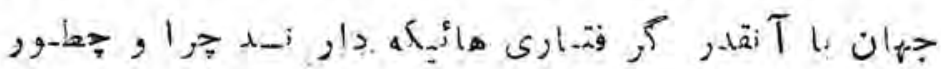

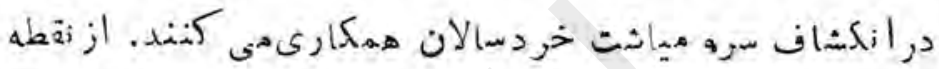

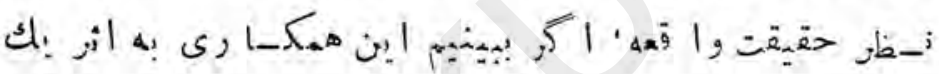

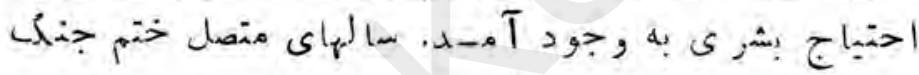

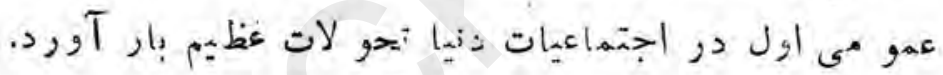

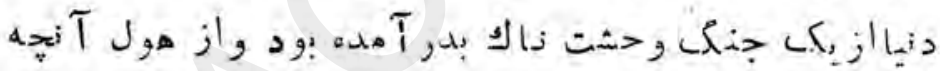

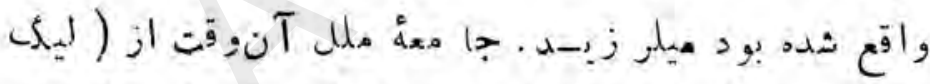

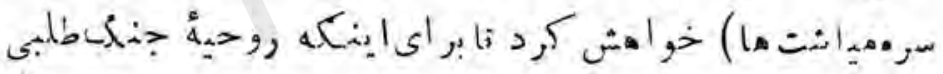

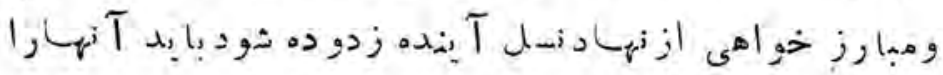

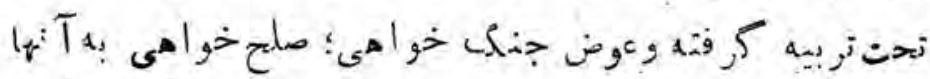

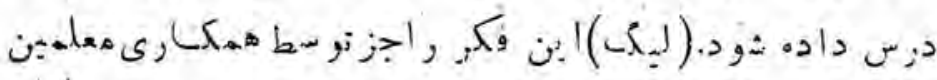

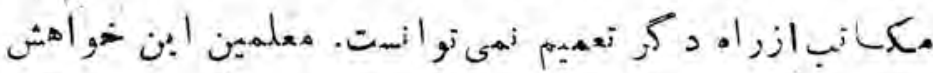

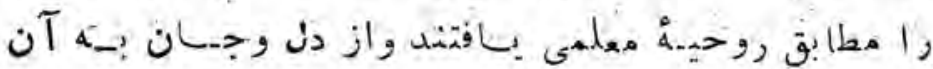
ن is 
(Iv)

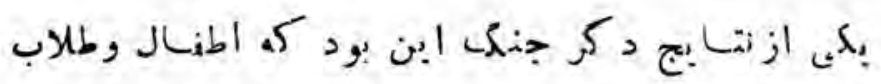

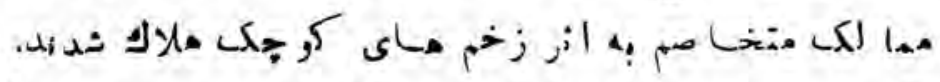

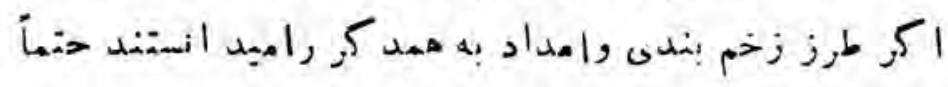

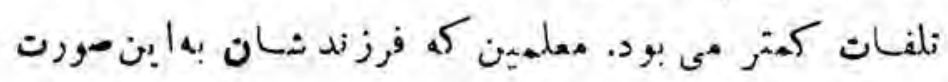

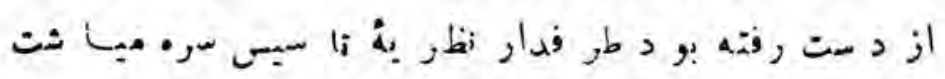

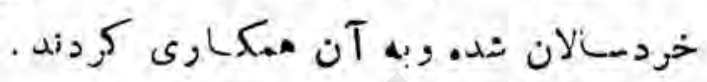

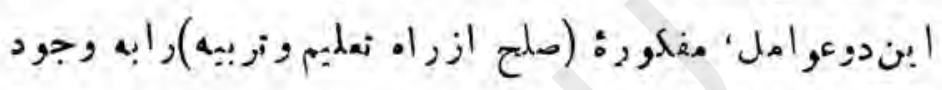
T

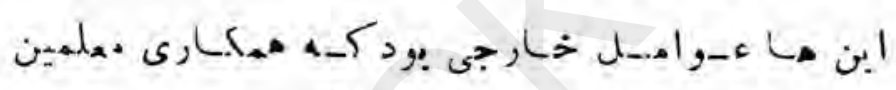

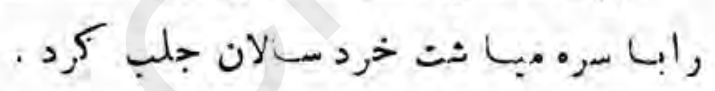

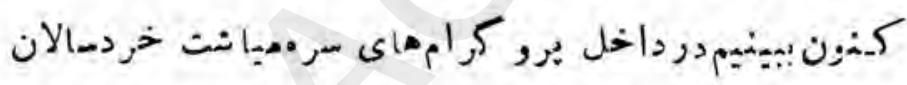

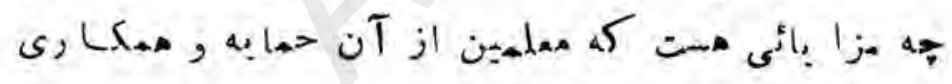

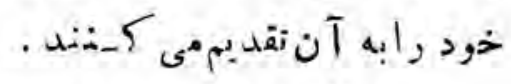

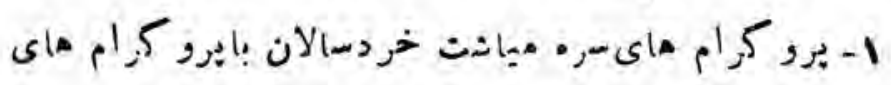

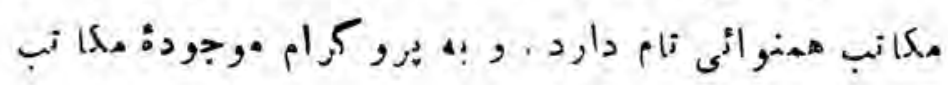

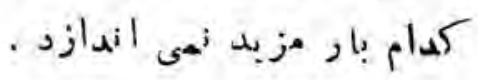

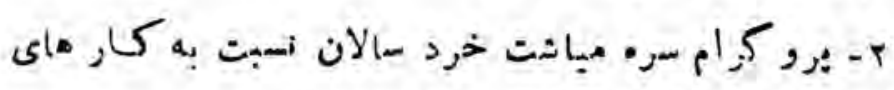

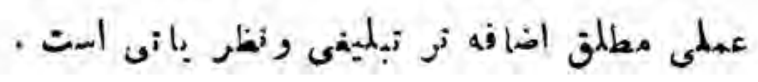


(11)

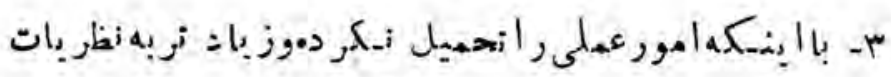

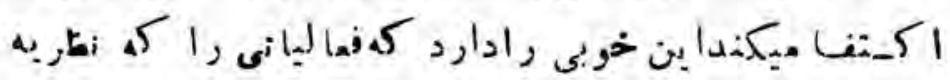

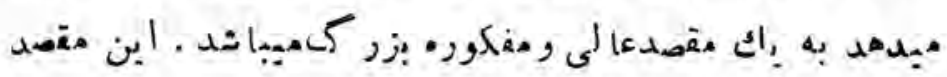

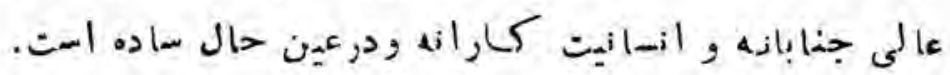

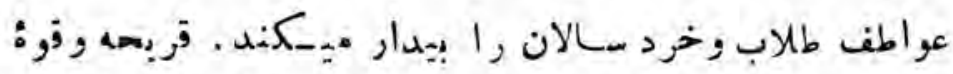

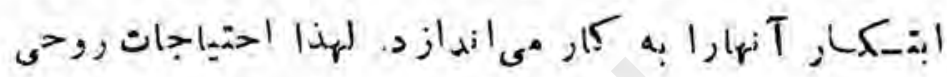

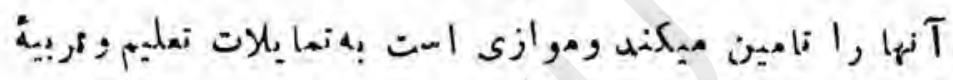

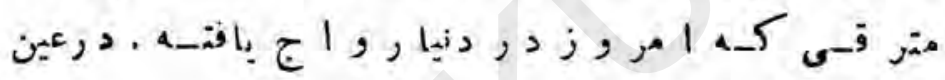

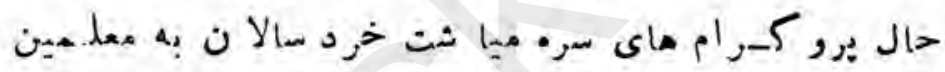

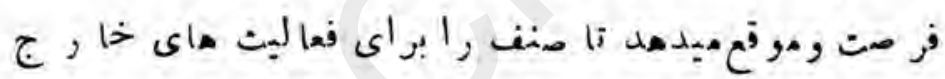

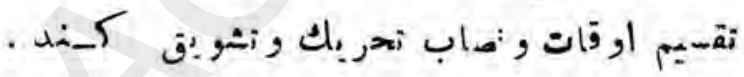

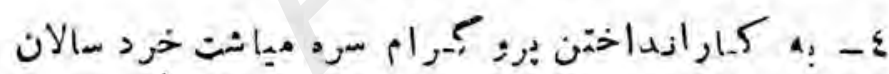

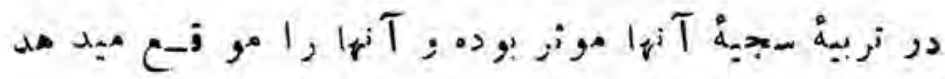

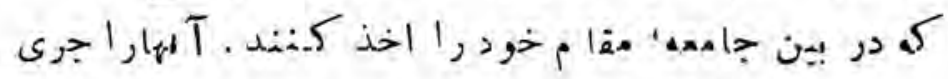

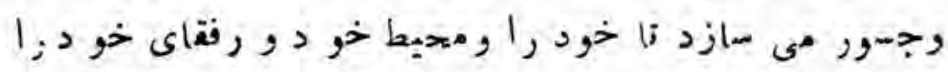

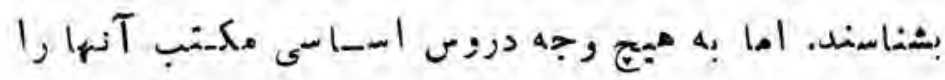
اخلال نميك-ند . به ابن صورت در يرو كرامسر. مياشت آموزش ويُرورث 
(19)

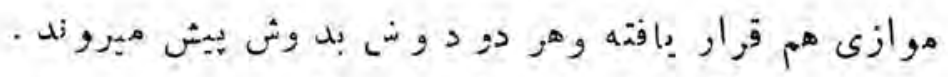

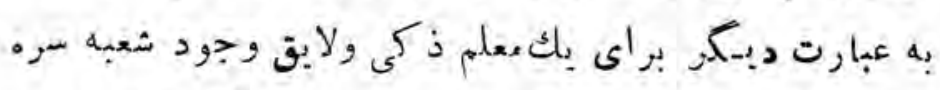

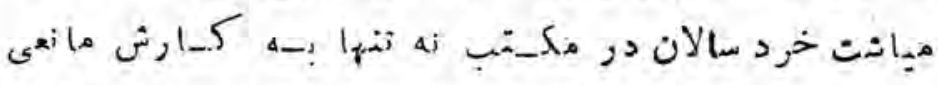

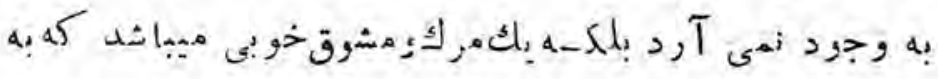

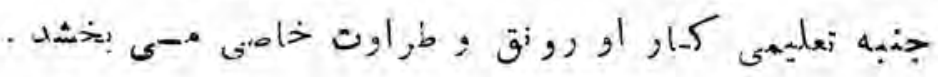

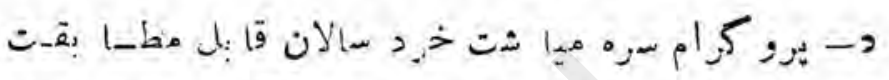

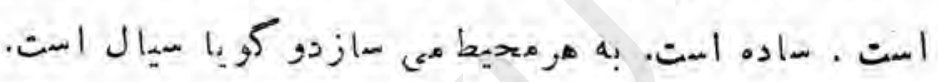

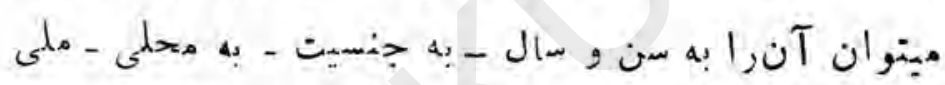

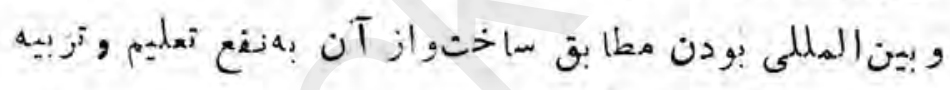
وبثر دوستى كـار, كـرفت .

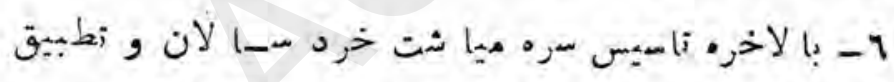

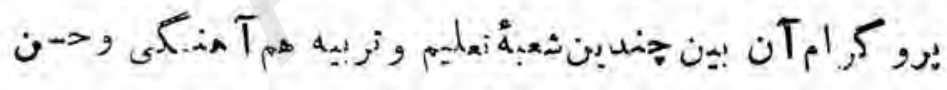

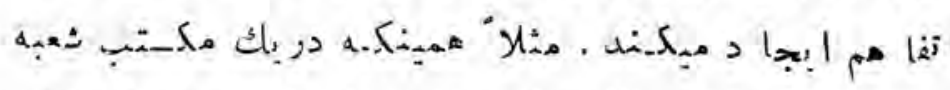

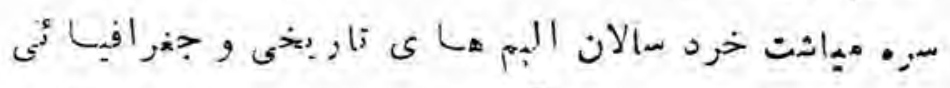

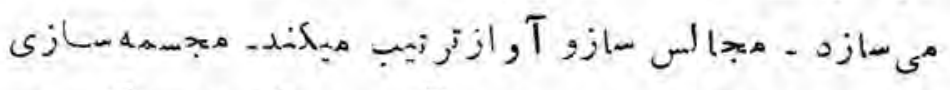

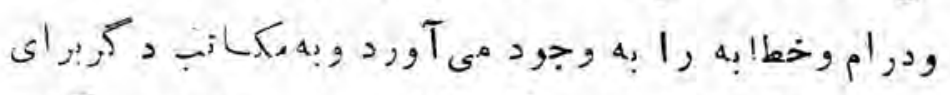

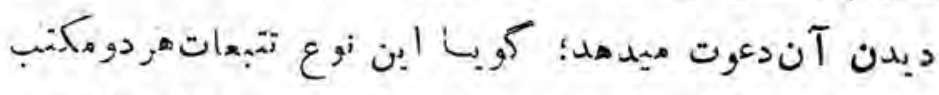

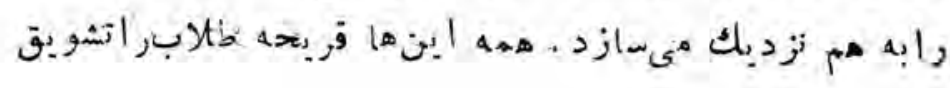


ir.)

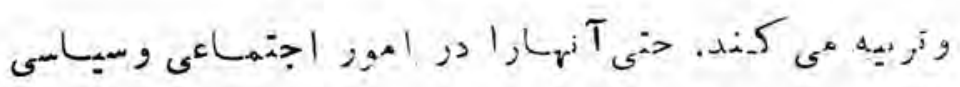

. مانس

$: 400$

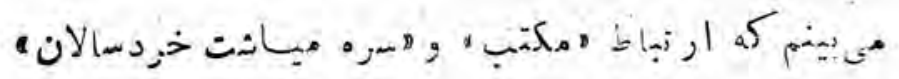

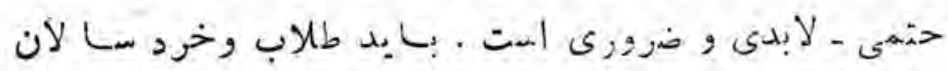

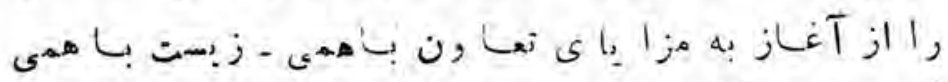

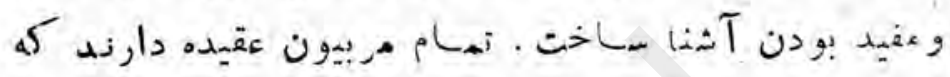

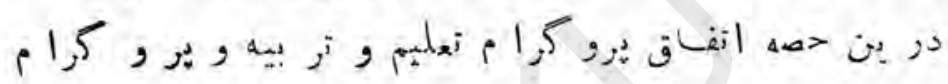

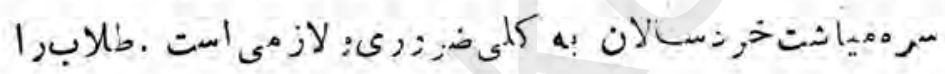

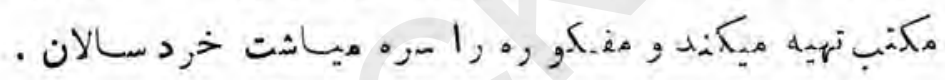

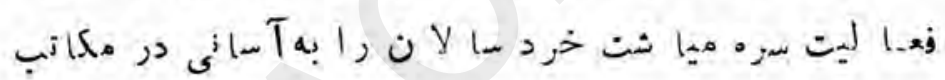

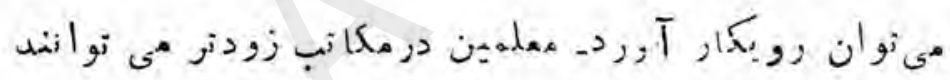

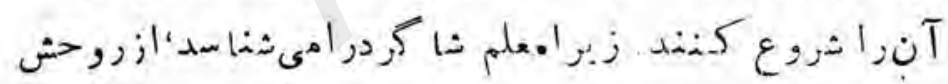

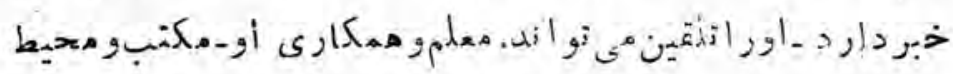

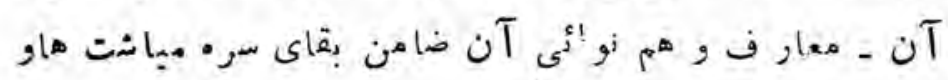

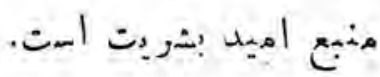

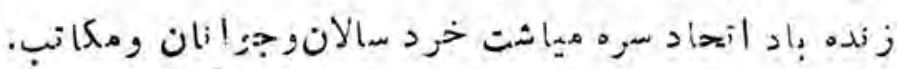




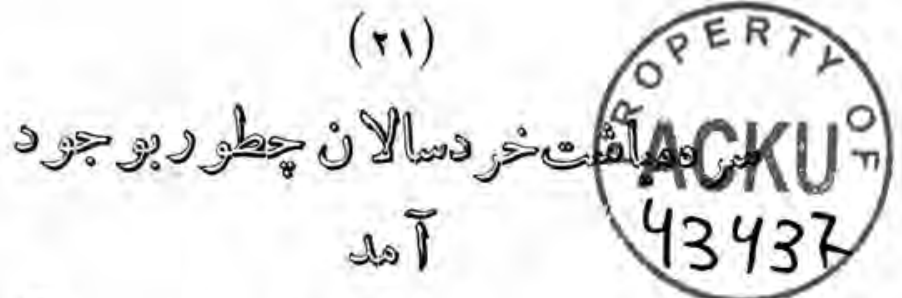

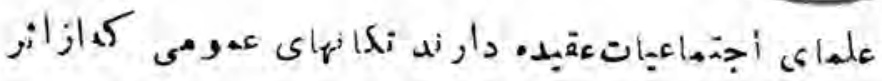

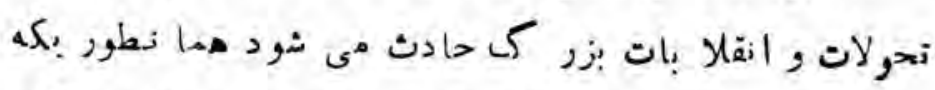

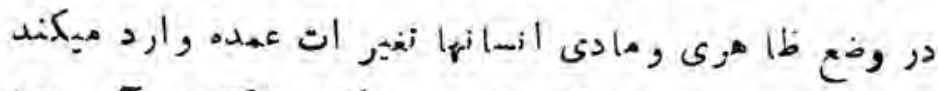

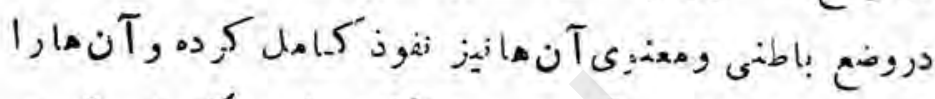

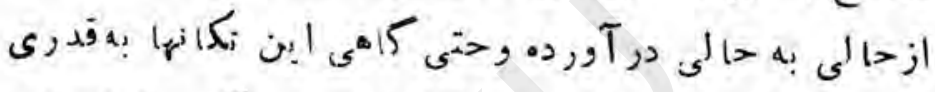

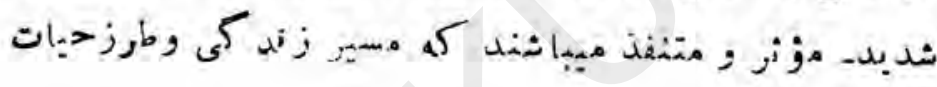

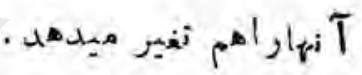

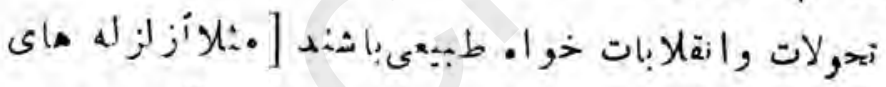

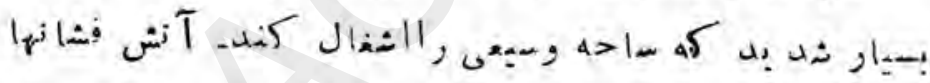

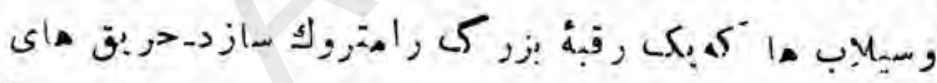

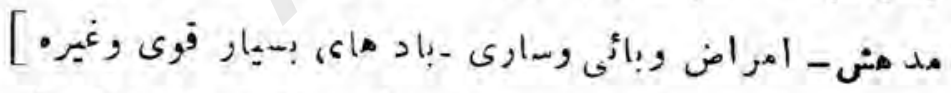

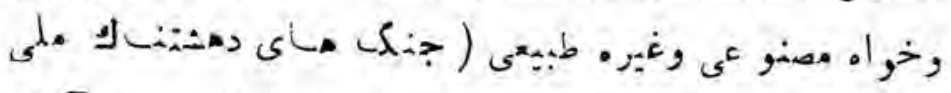

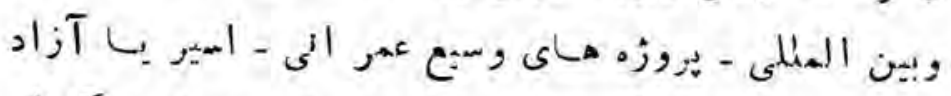

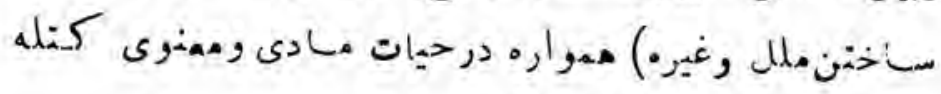

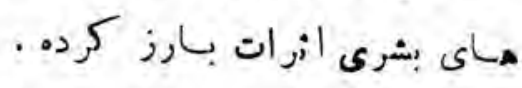

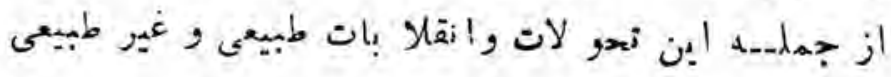


(rr)

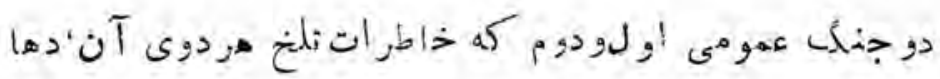

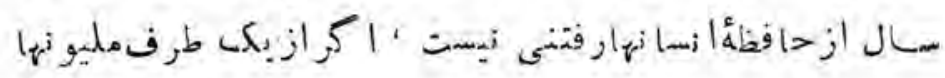

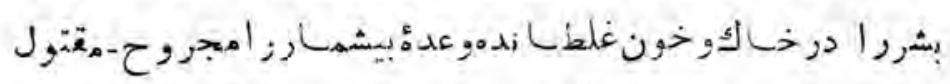

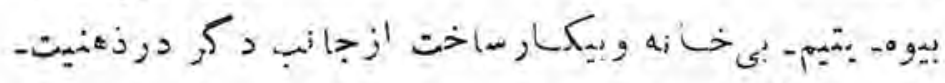

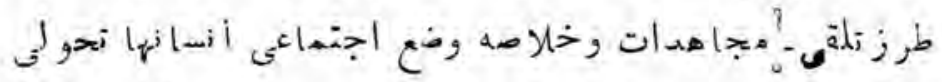

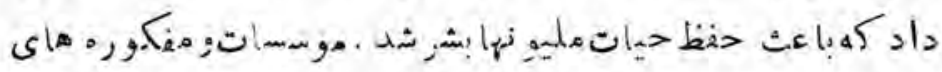

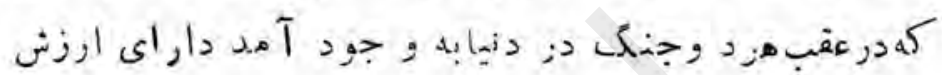

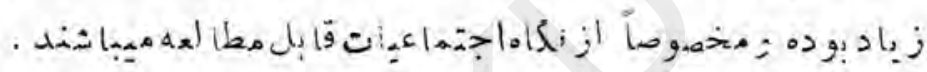

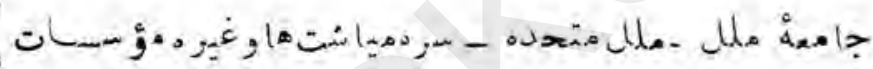

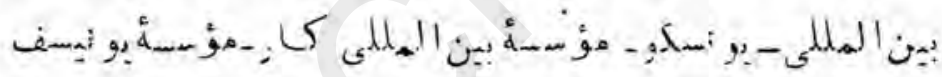

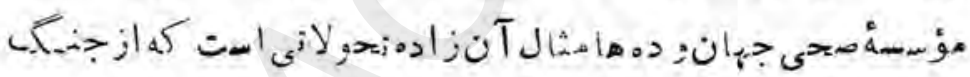

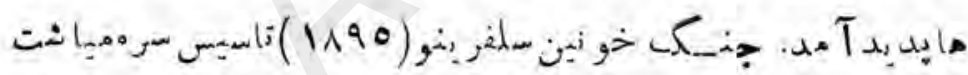

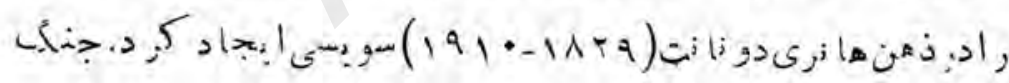

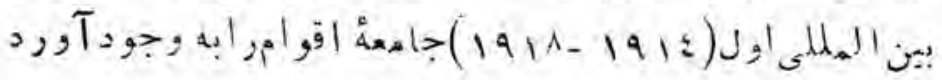

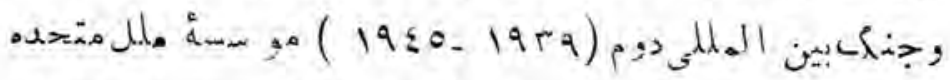

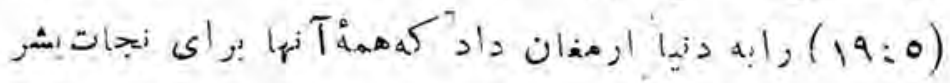

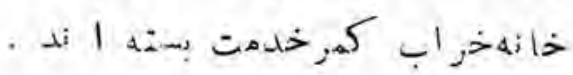

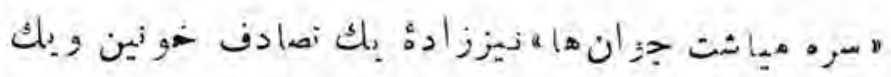


$(r r)$

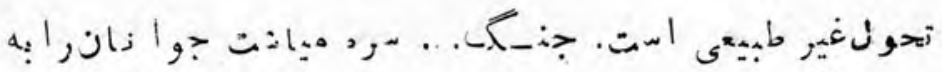

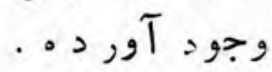

هiه

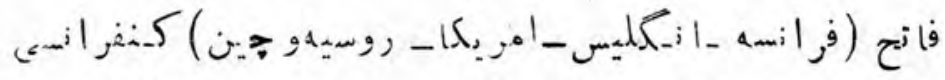

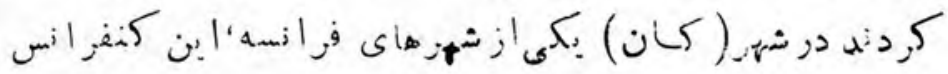

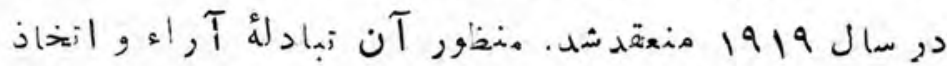

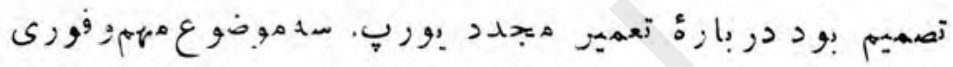

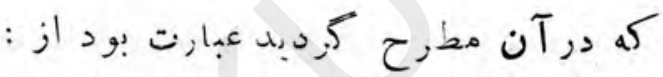

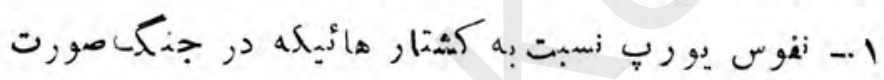
كر فته بود زقليل بأفته بود د.

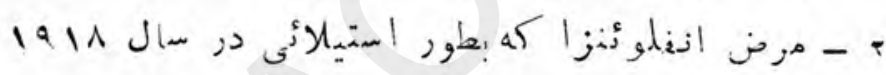

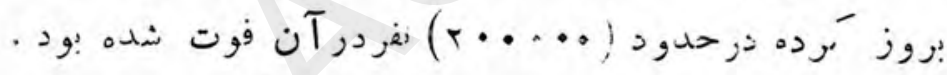

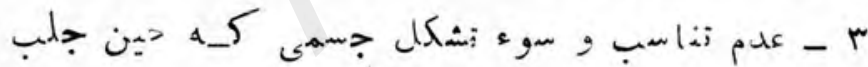

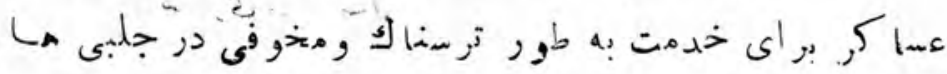
ديد. شده بو د د.

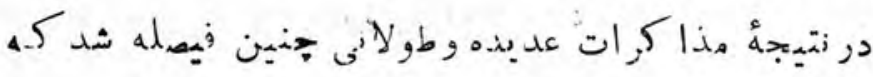

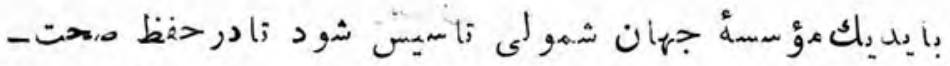

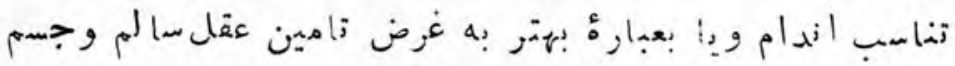

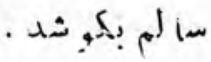


$(r z)$

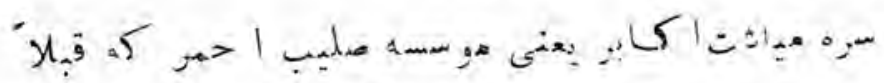

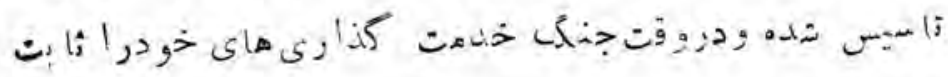

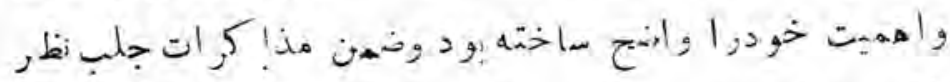
كأن

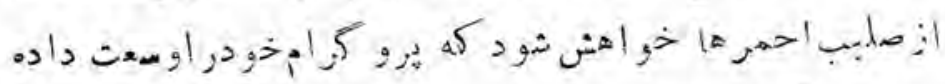

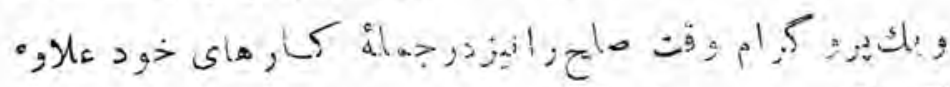

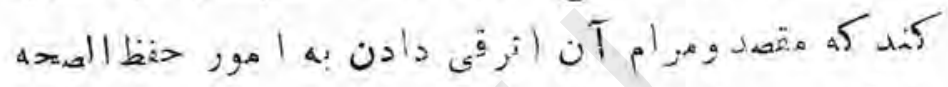

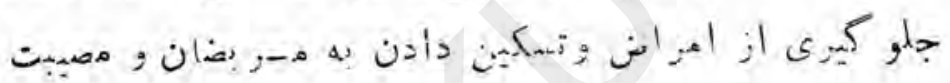

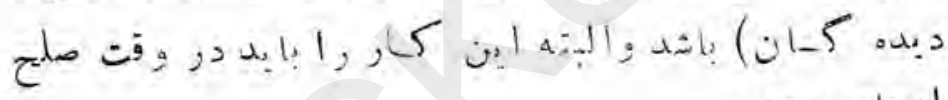

in

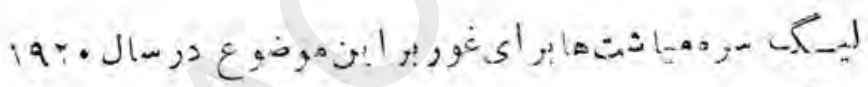

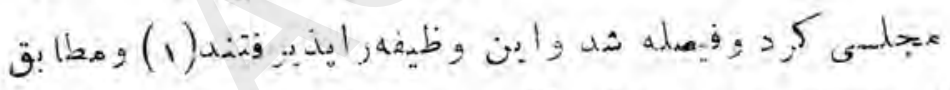

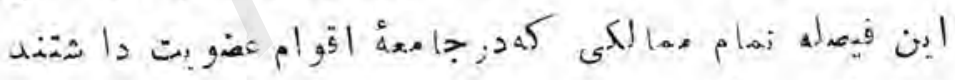

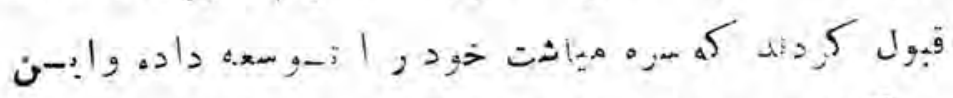

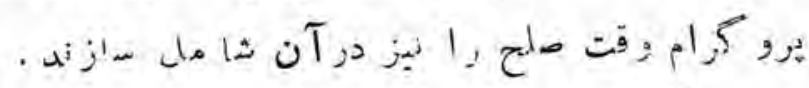

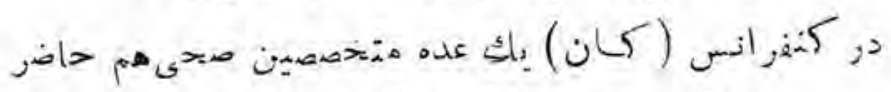

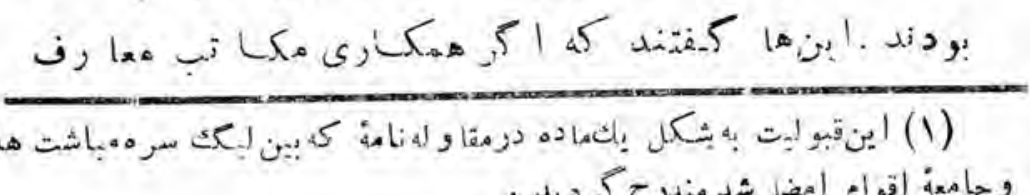

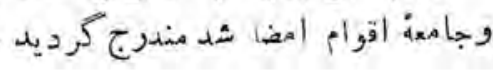




$$
(r \circ)
$$

و

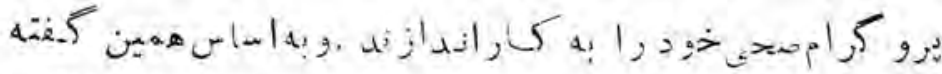
بو 200

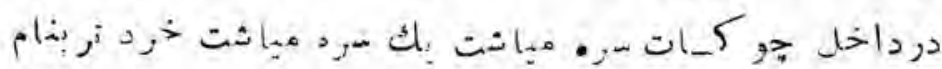

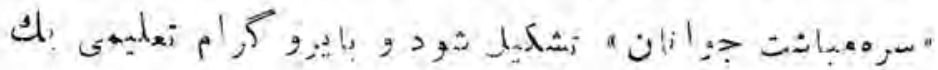
. 2,

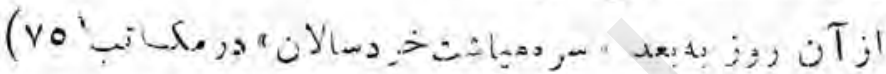

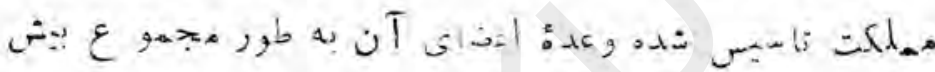

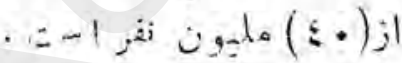

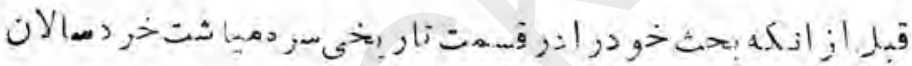

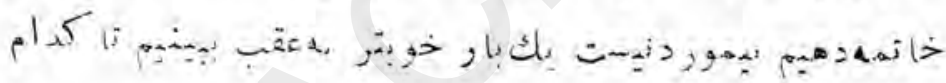

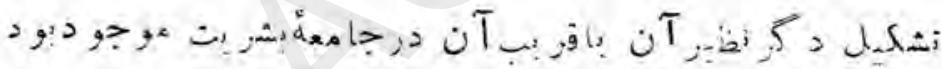
i 1 :

,

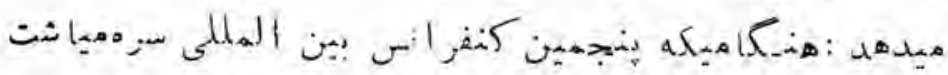

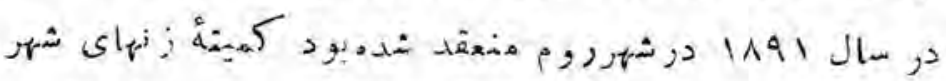

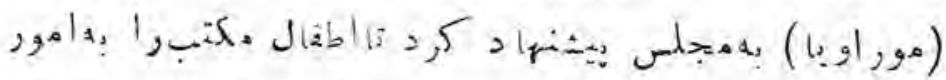

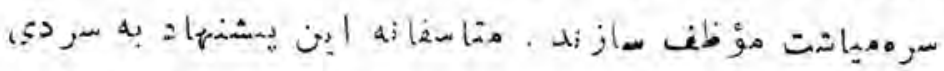

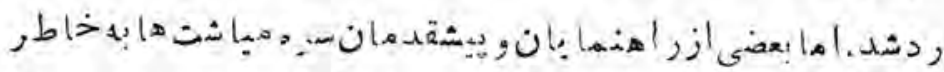




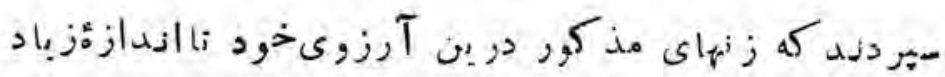

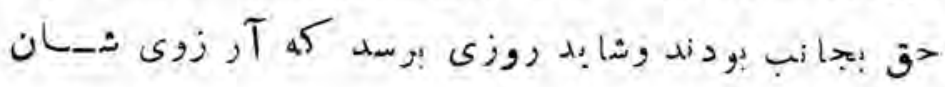

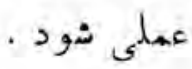

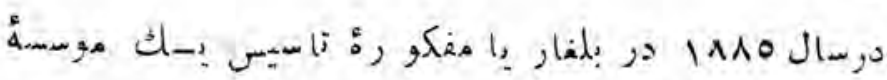

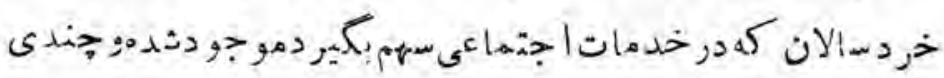
$.42,5$ s

1, در سال

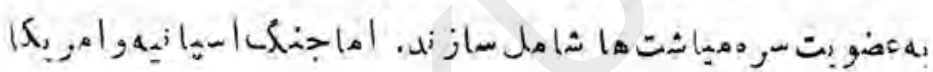

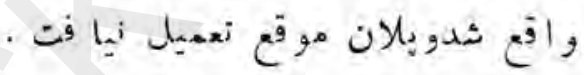

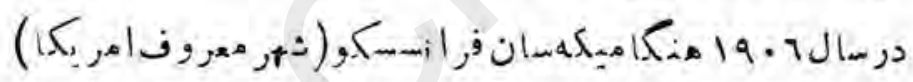

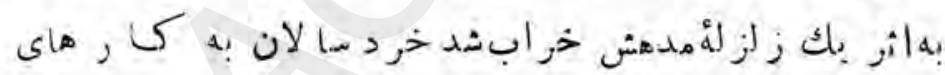

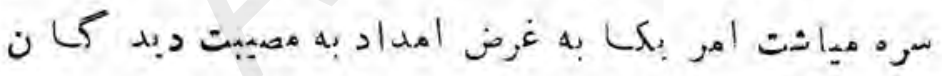

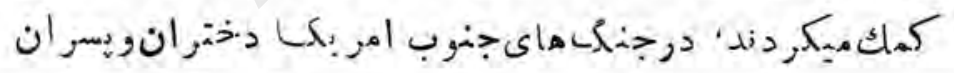

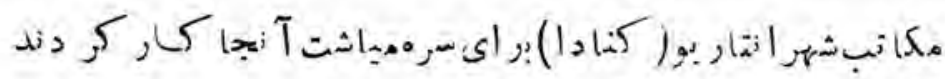

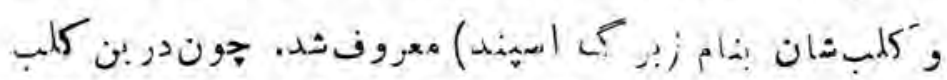

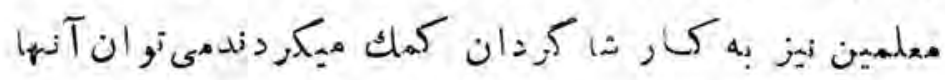

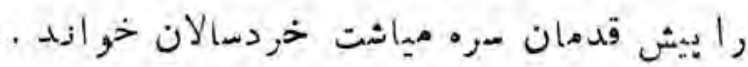

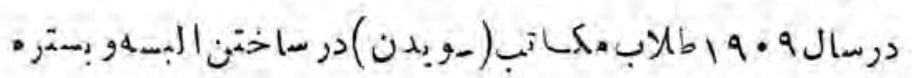


(TV)

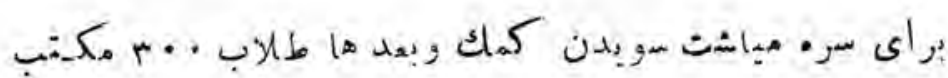

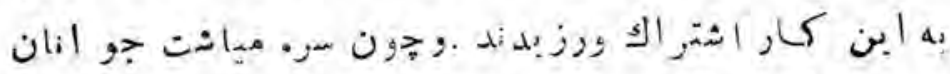

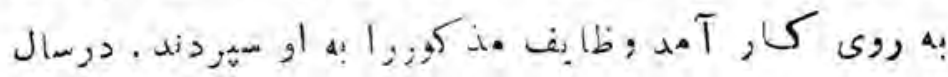
آ هآ 1912

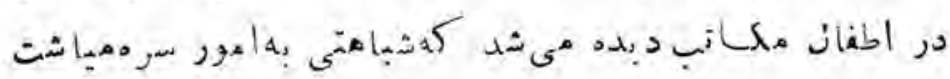

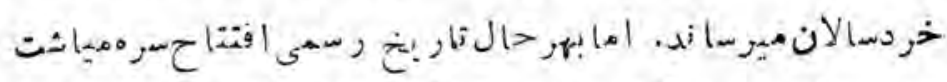

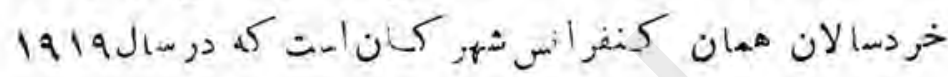

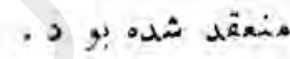


$(r \wedge)$

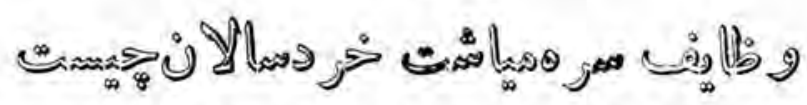

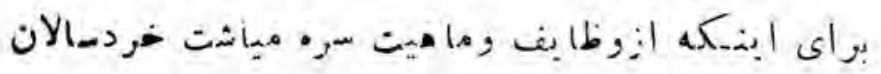

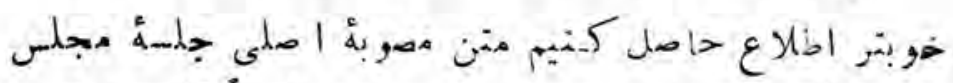

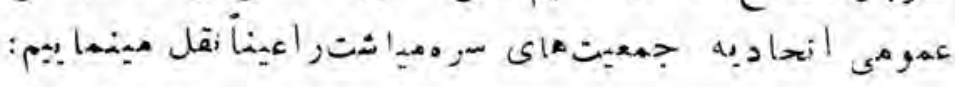

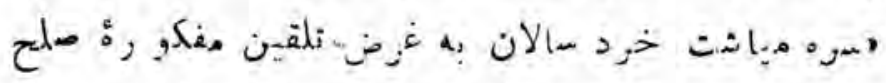

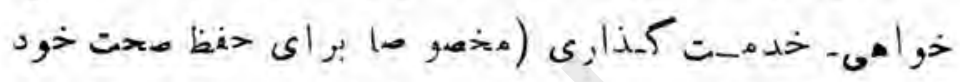

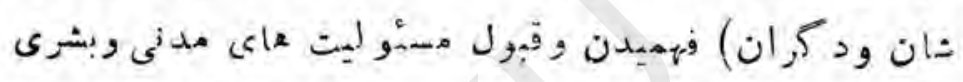

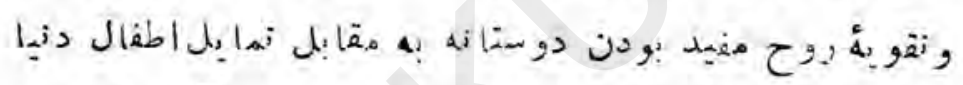

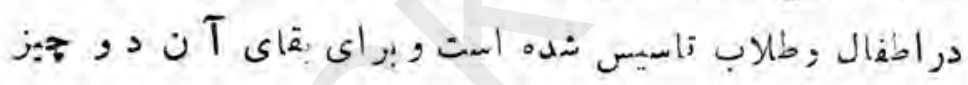

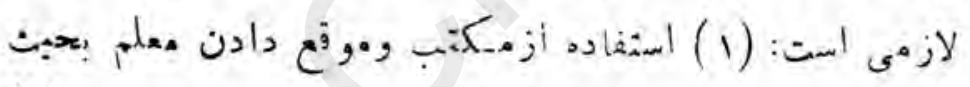

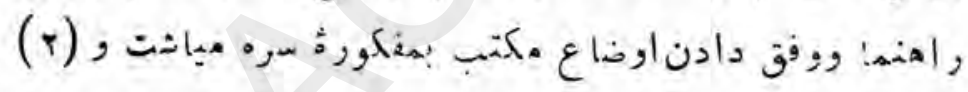

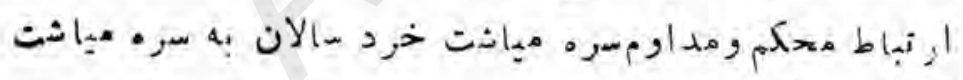
lo Ji- ن

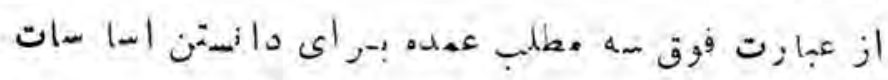

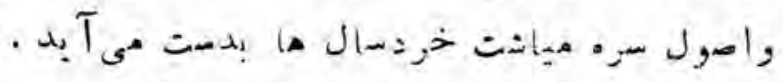
(1) (خدمت(r) صحت(r) دوستي بين المللمي.

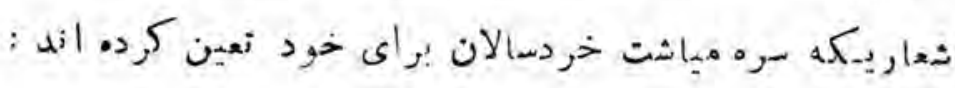
“ 
$(+9)$

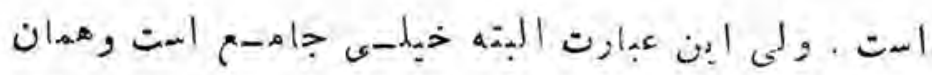

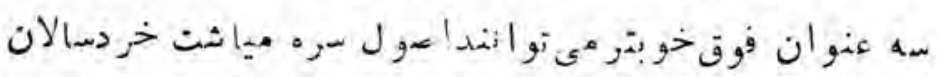

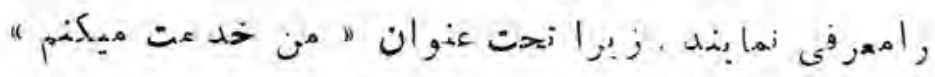

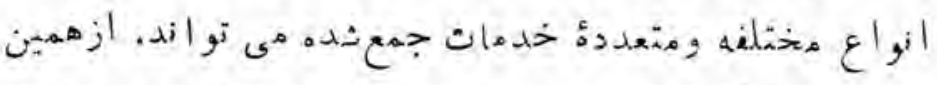

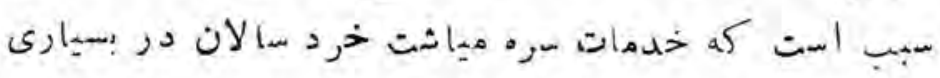

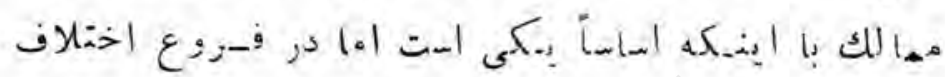

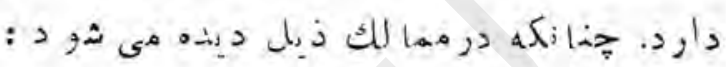

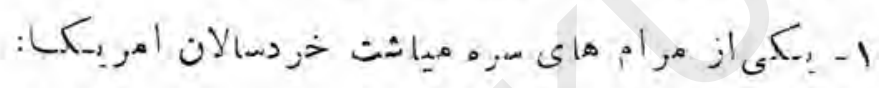

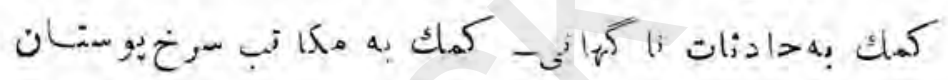

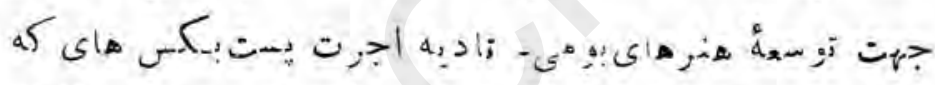

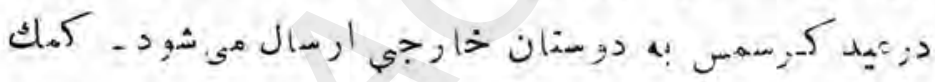

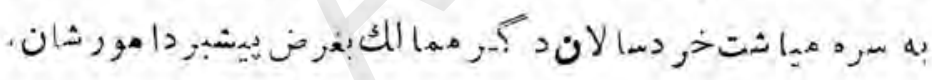

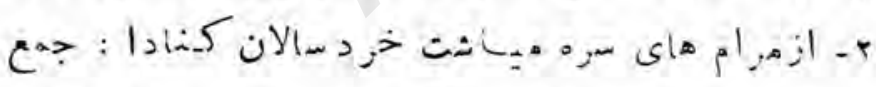
آ:

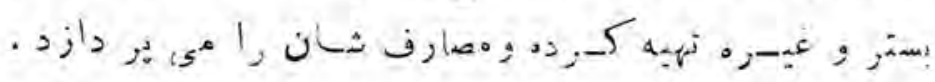

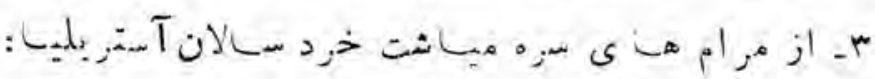

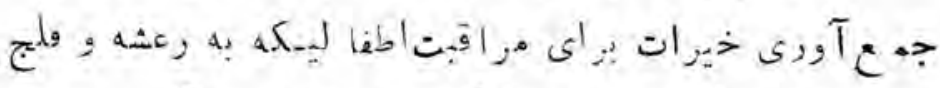

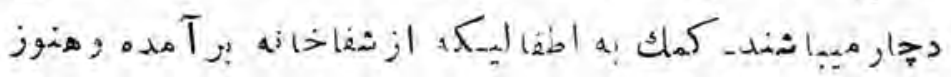


$(r \cdot)$

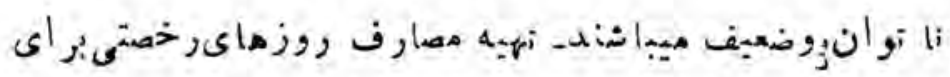

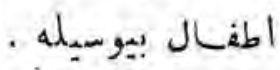

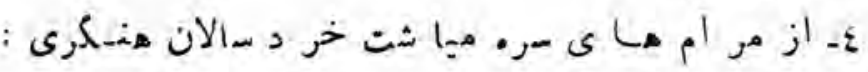

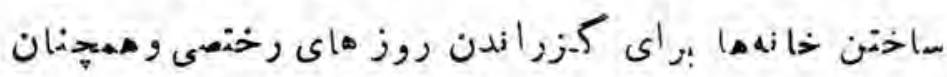

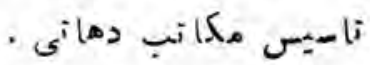

هـ از هـرام سره ميـاشث خ-رد سـالان بو ك.وسلاو بـا:

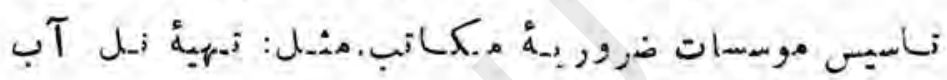

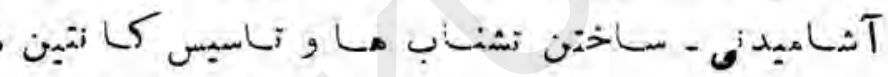

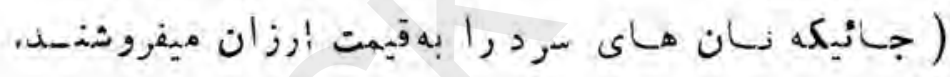

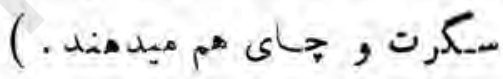

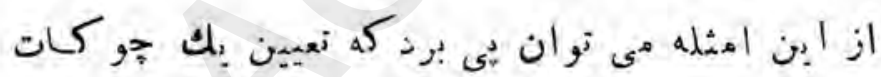

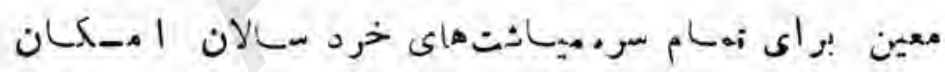

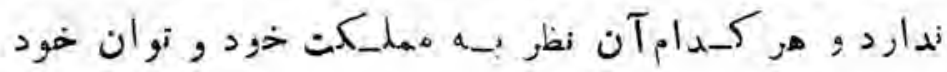

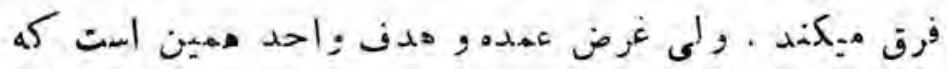

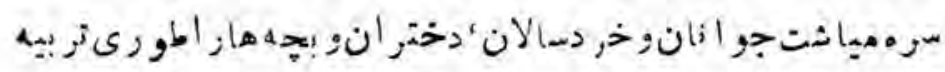

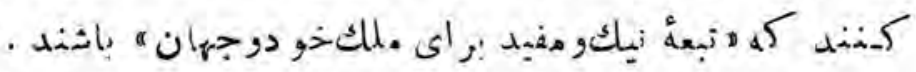

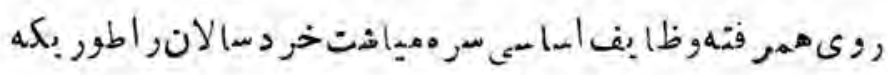

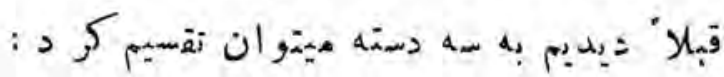


$(r)$

الف:وظ) إنف اجتماعى : (خلمت)

-

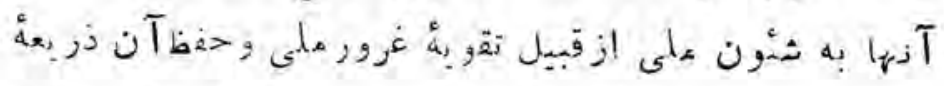

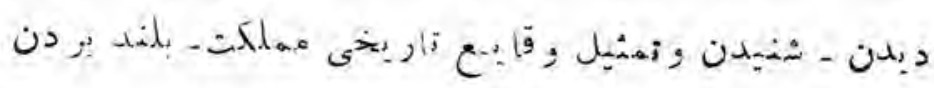

س

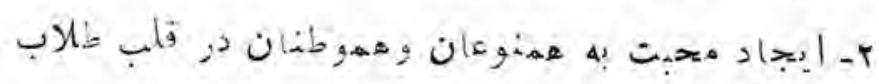

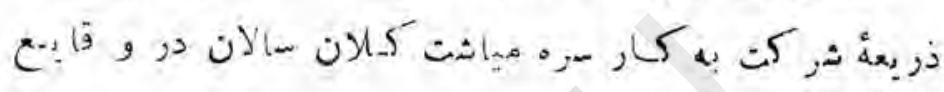

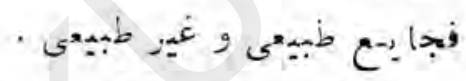

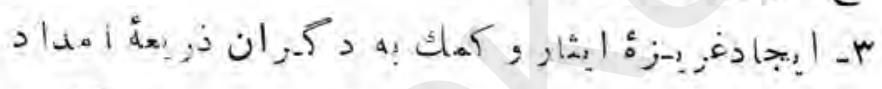

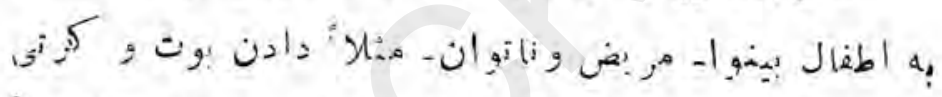

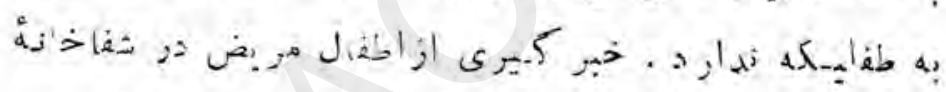

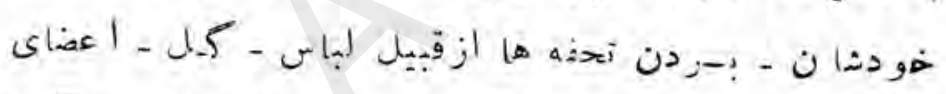

أi

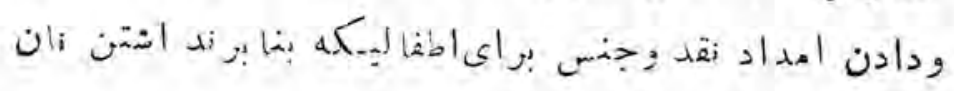

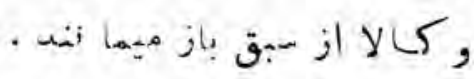

E

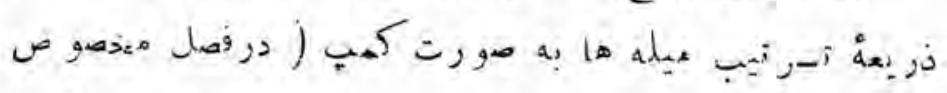

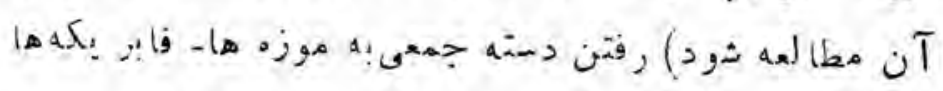


$(r r)$

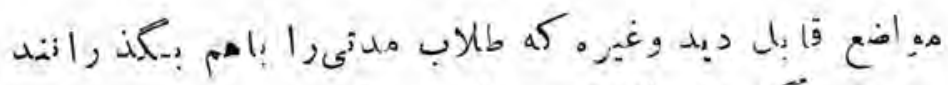

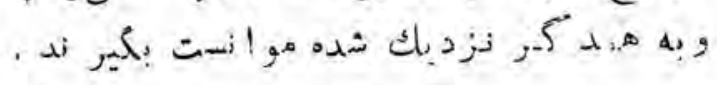

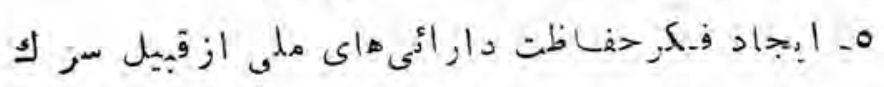

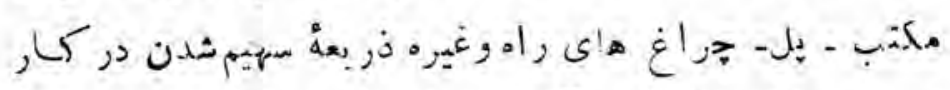

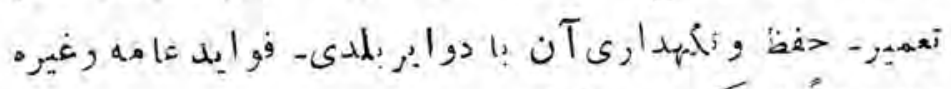
هخ

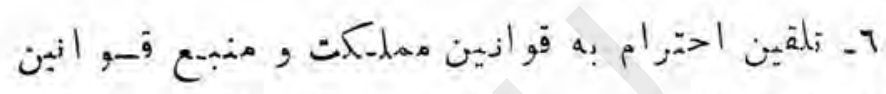

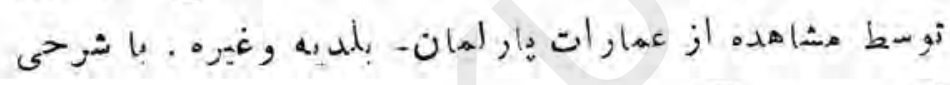

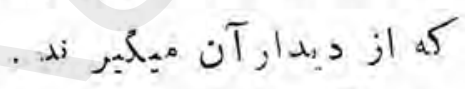

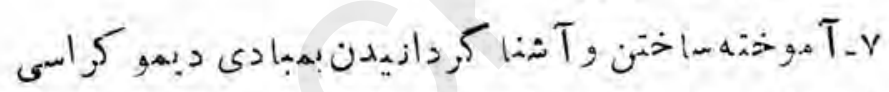

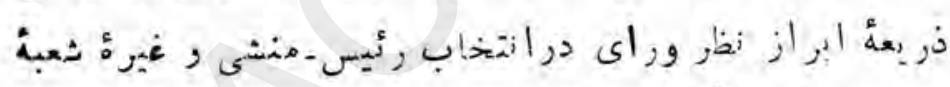

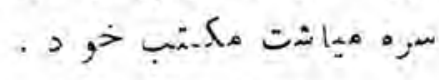

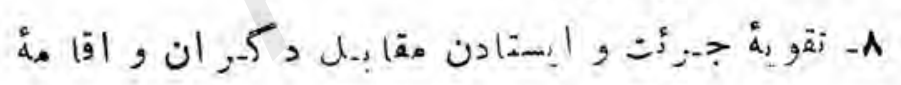

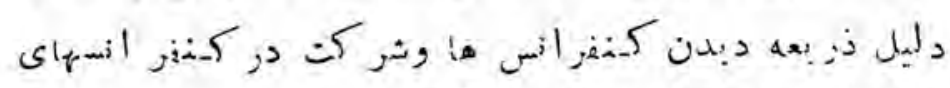

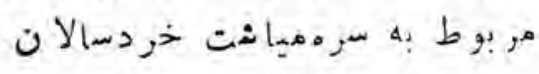

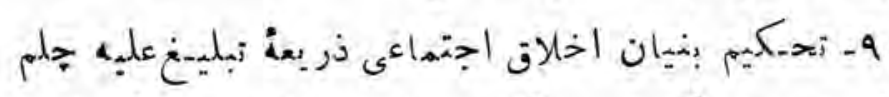

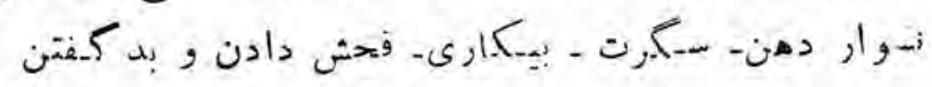
• . L ا 
$(\mu r)$

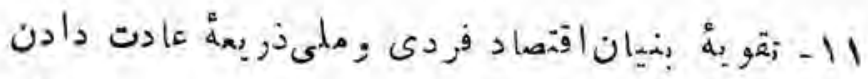

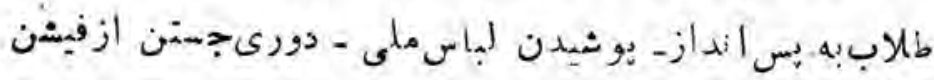

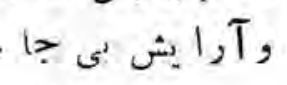

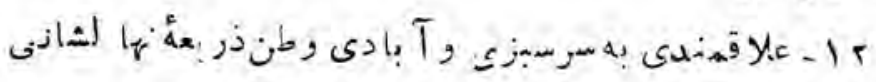

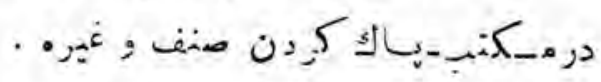

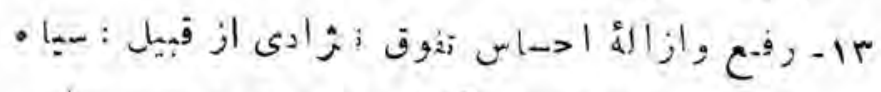

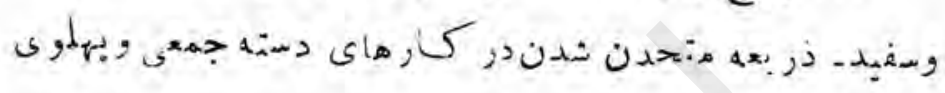

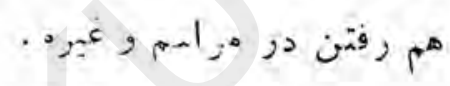

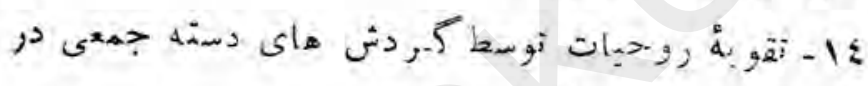
كاك

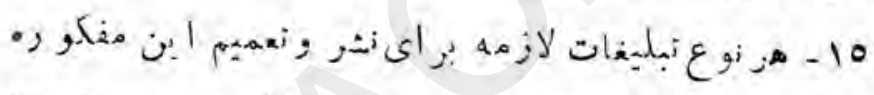

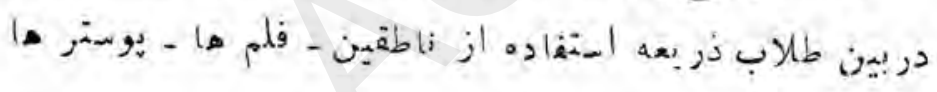
…다. lom

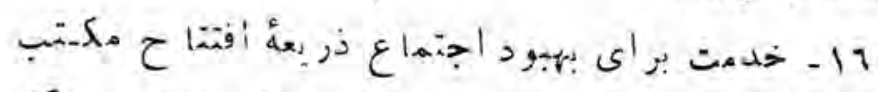

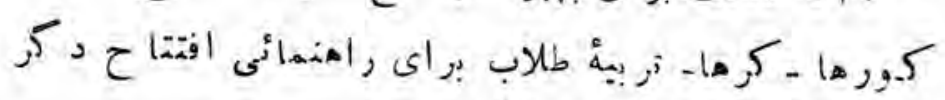

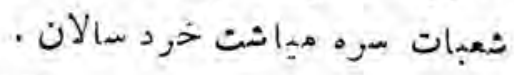

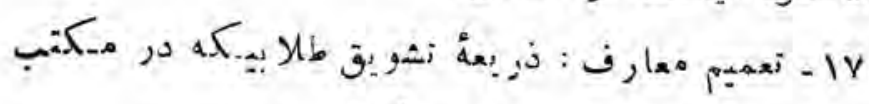

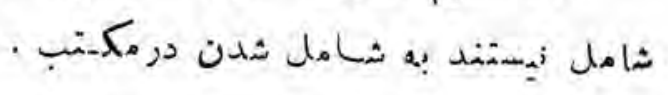

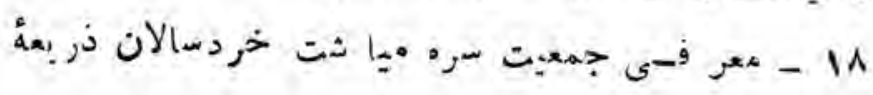


$(r \varepsilon)$

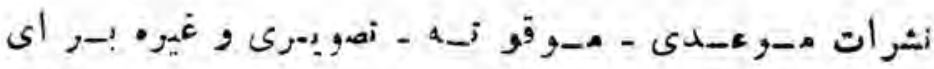

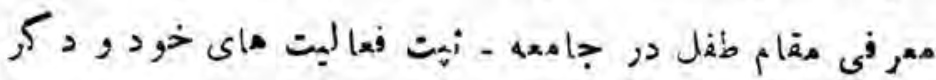

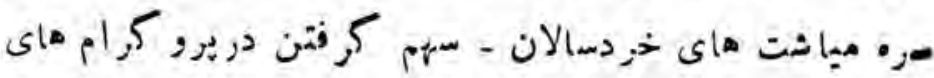

رادرو وغير• د,دانخل وخار ج

19 - 19

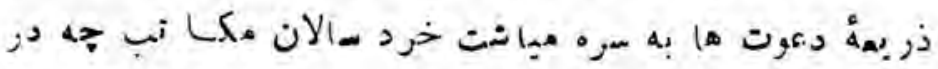

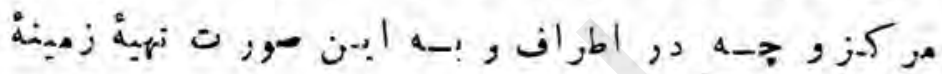

.

: - وظالفصحى

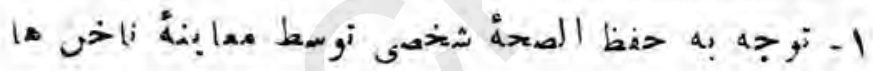

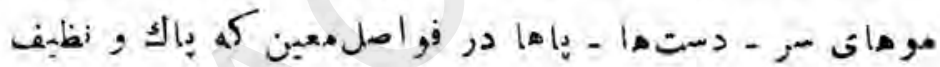

. $\sin L$

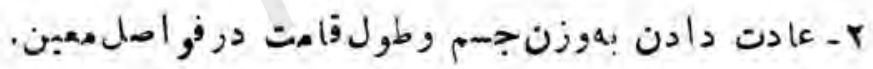

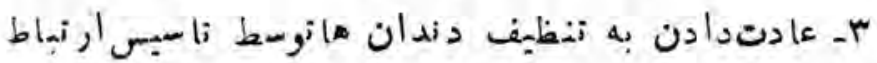

با مقا مات ط:ى

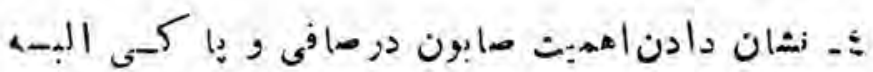

جسمبروني

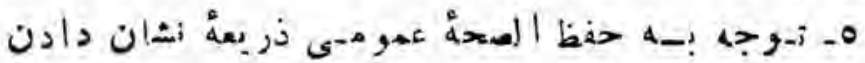


(ro)

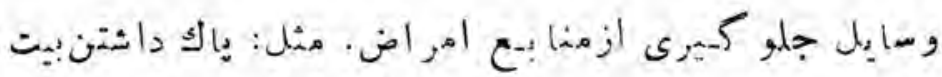

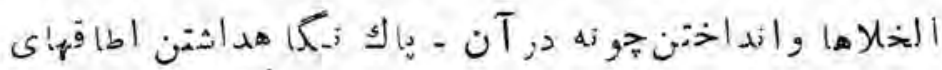

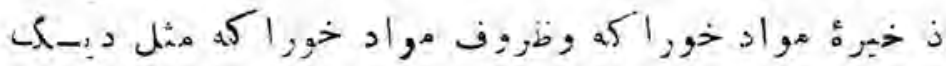

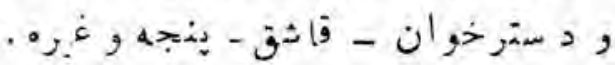

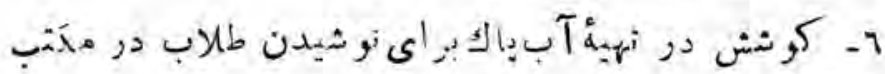

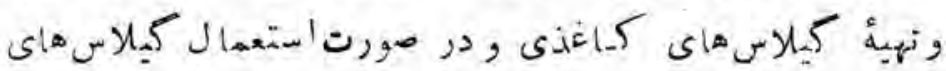

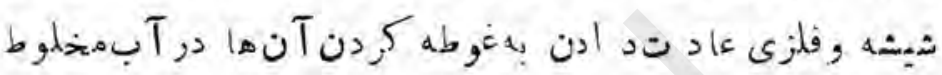
- lisiogle

ri - V

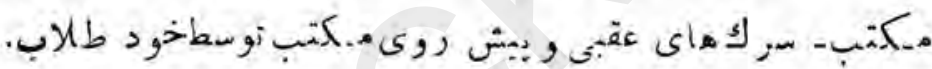

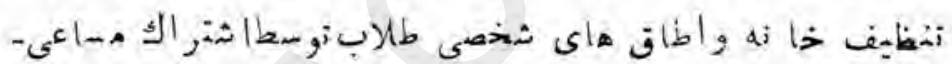

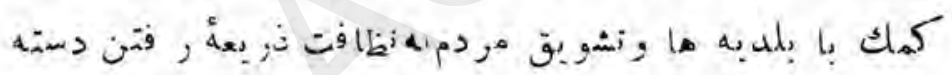

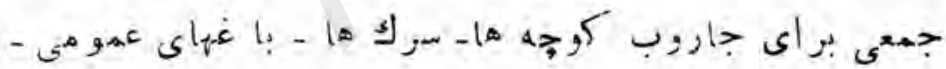

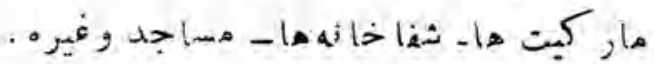

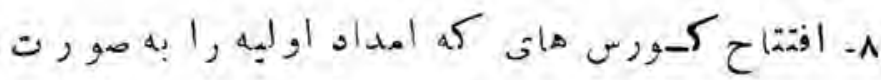

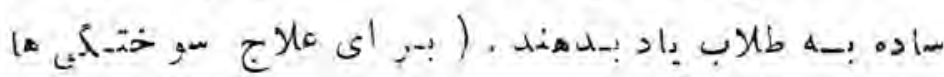
( ) إنم

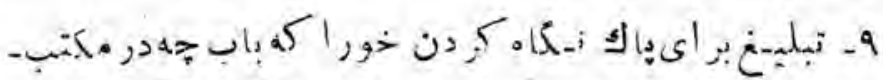
جن 
(rq)

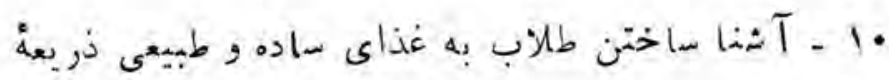

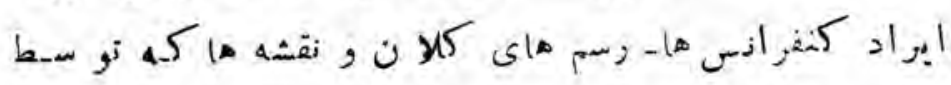

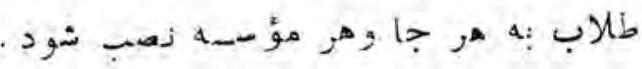
ها

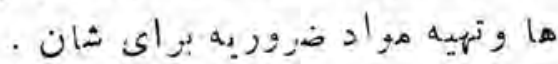

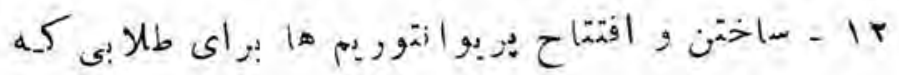

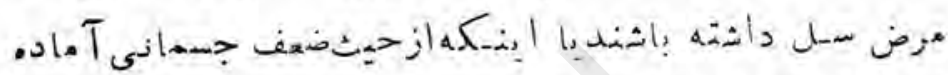

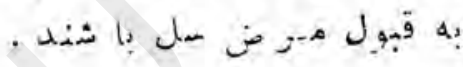

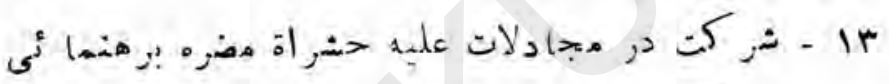

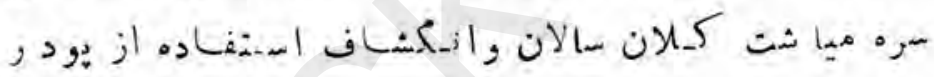
.

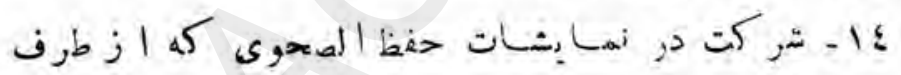

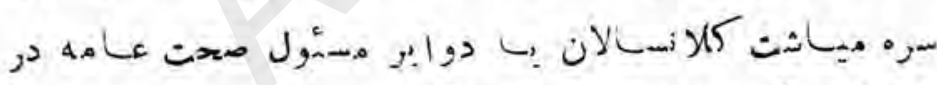

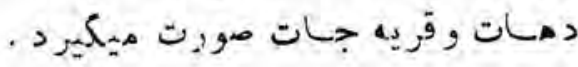

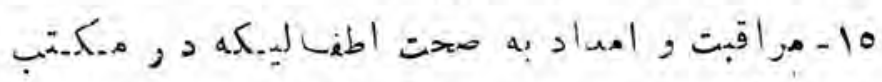

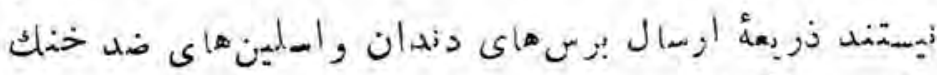
.

كاي كرم براى شان دور زمستان . 
(rv)

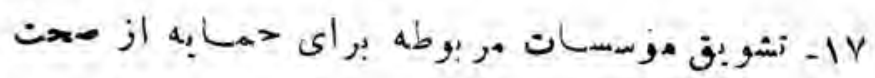

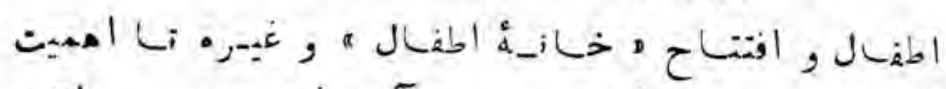

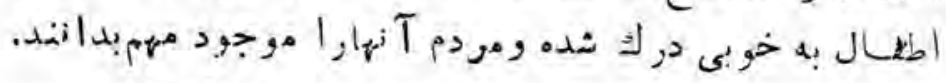

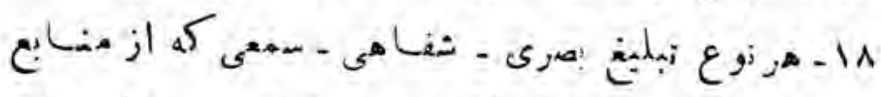

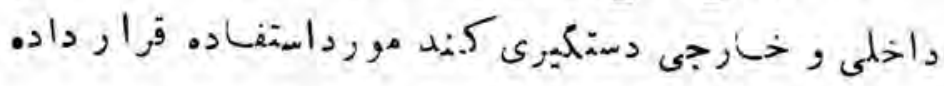

. 20

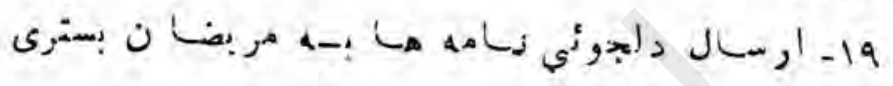

.

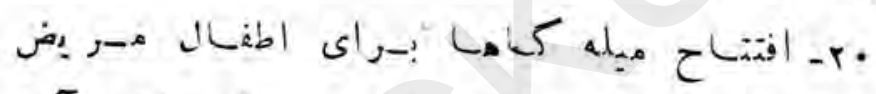

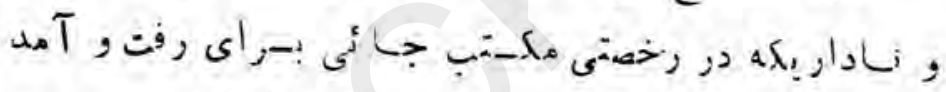

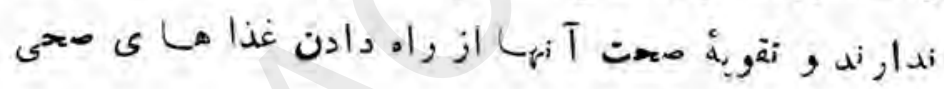

- ن أن

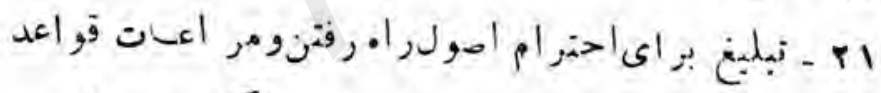

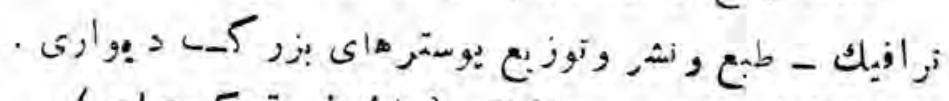

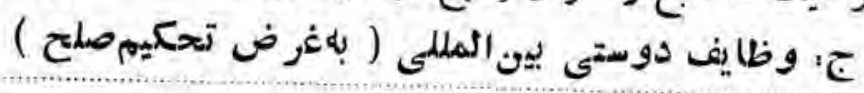

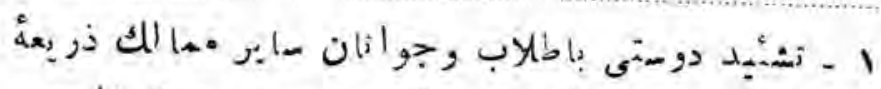

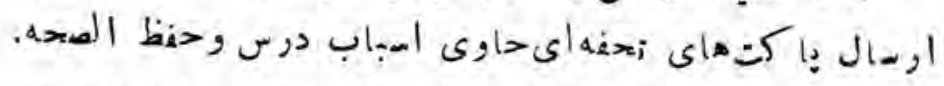

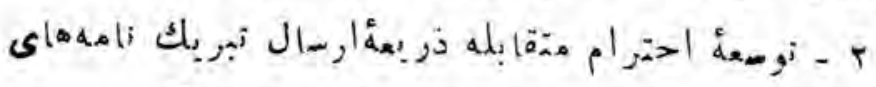

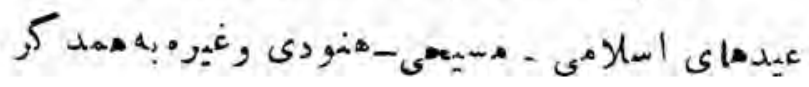


$(r \wedge)$

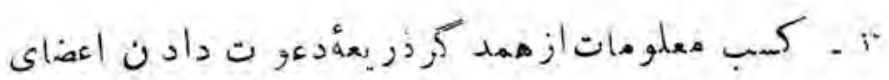

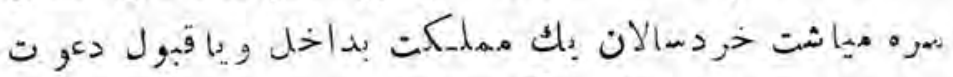

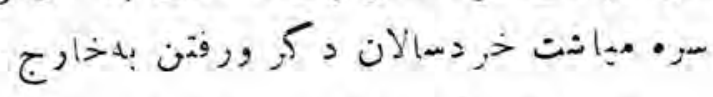

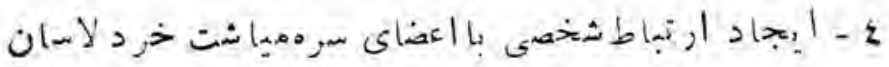

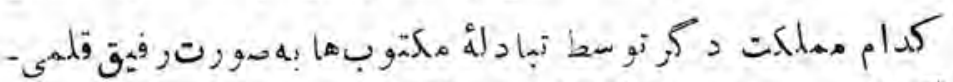

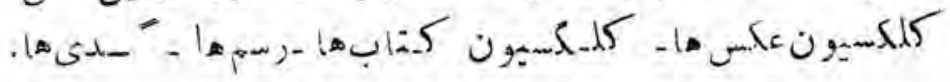

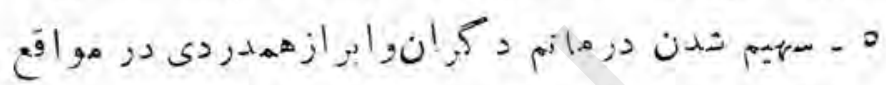

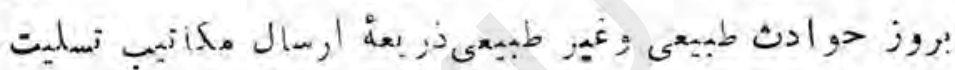

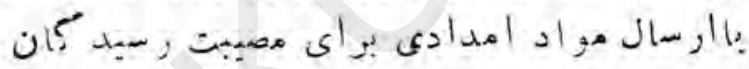

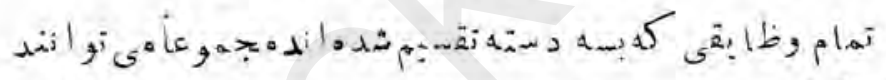

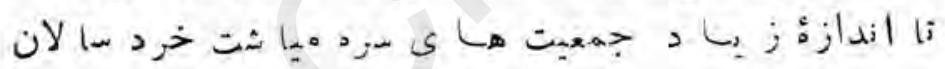

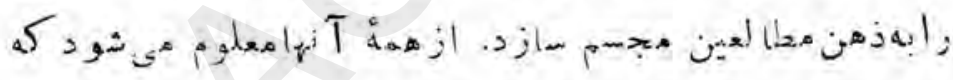

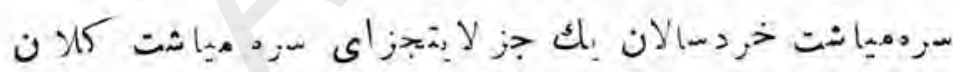

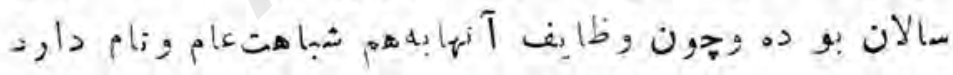

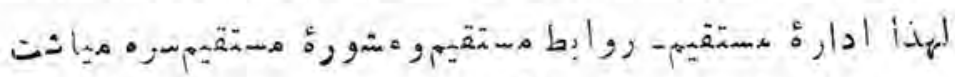

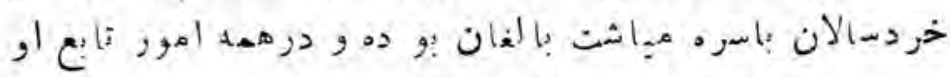

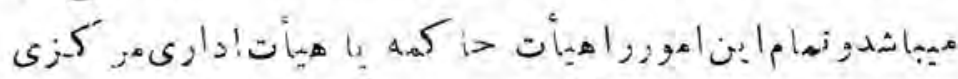

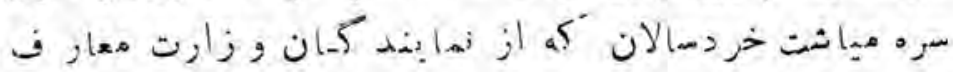

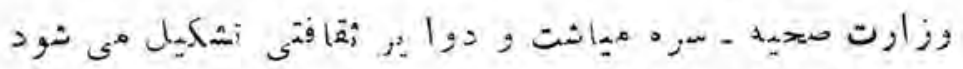

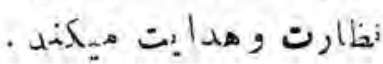


$(r q)$

O

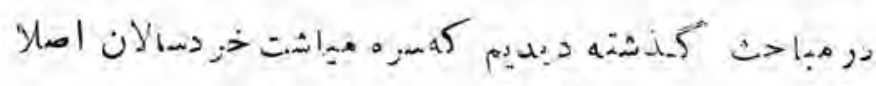

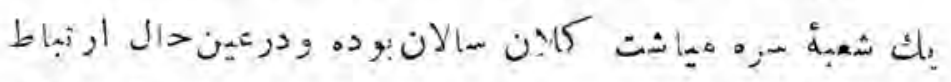

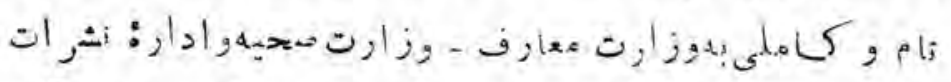

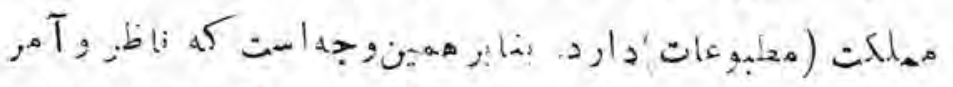

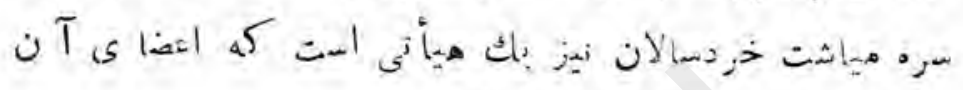

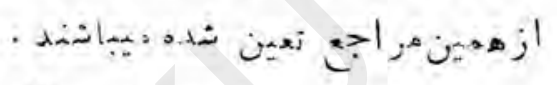

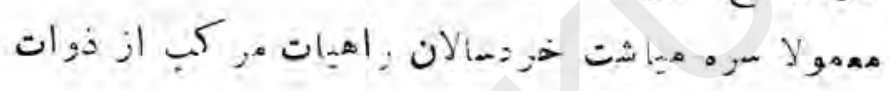

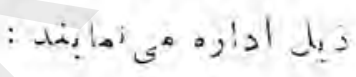

jesis

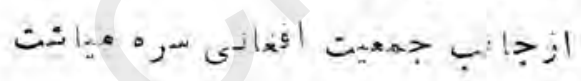

دونغن

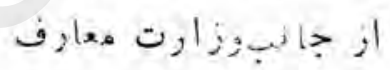

دوبر

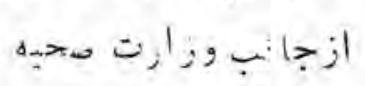

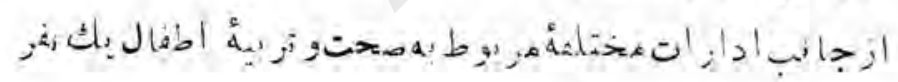

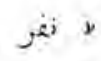

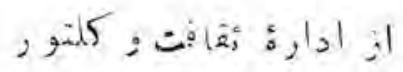

(j)

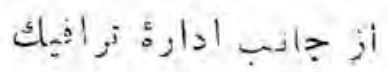

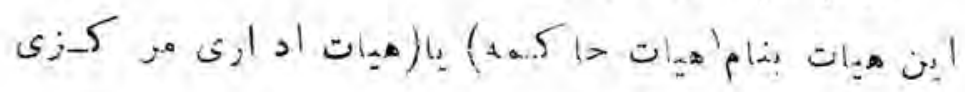

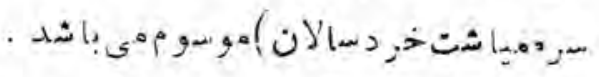

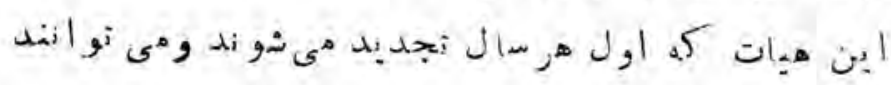


$(z)$

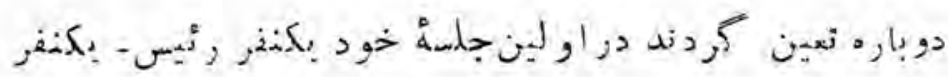

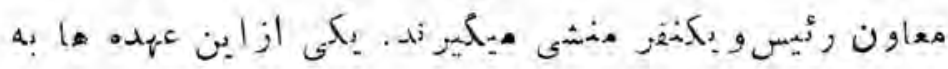

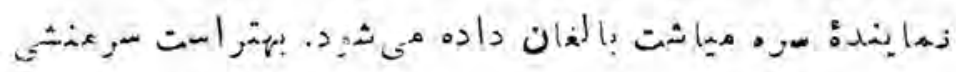

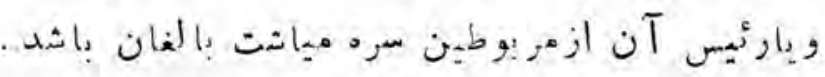

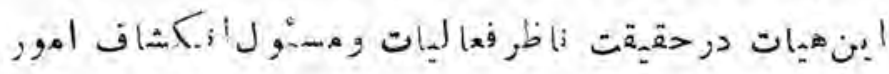

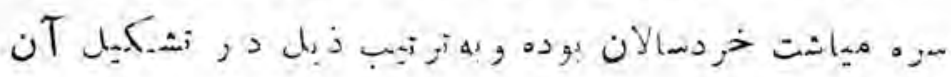

:

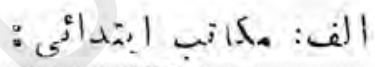

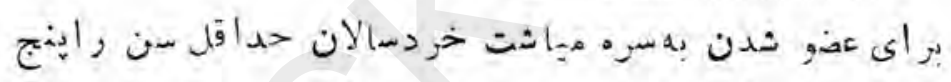

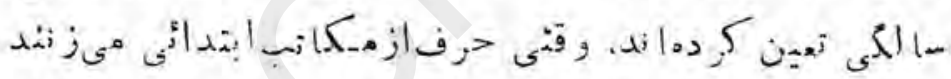

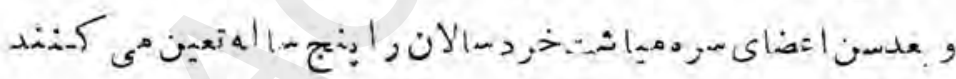

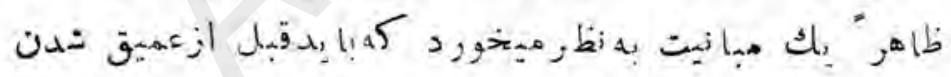

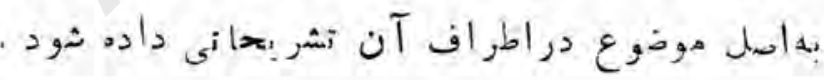

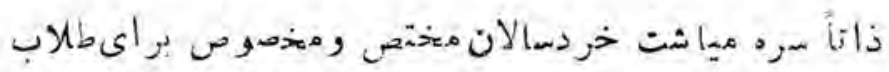

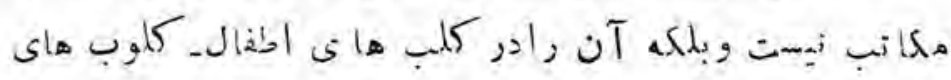

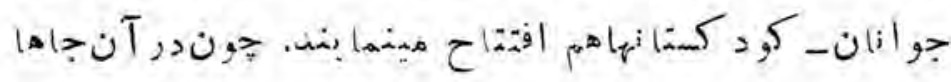

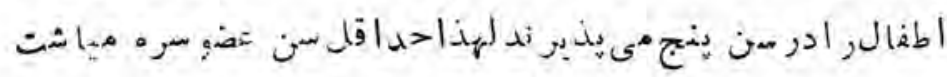

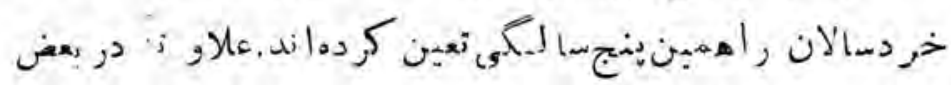


(; 1)

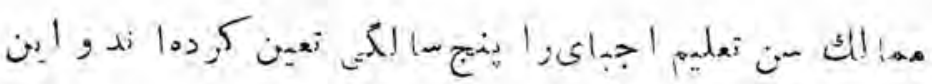

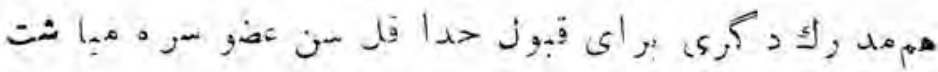

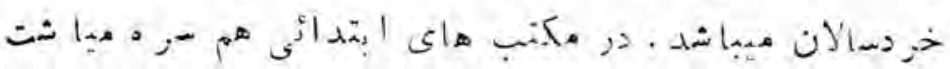

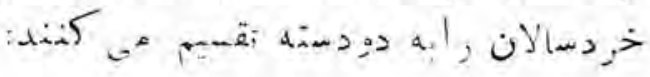

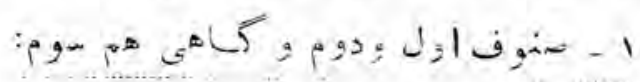

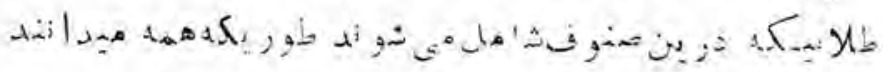

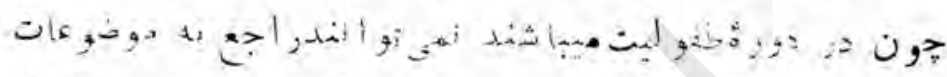

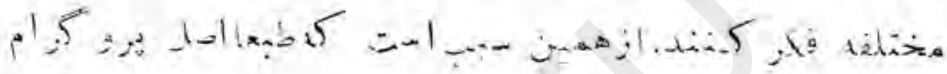

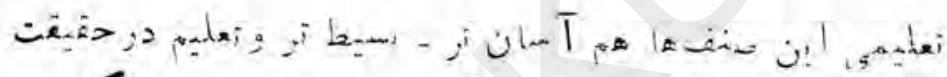

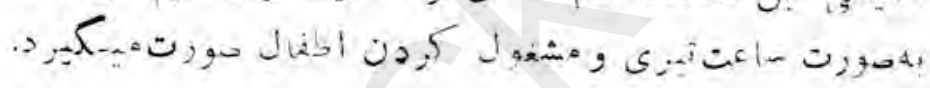

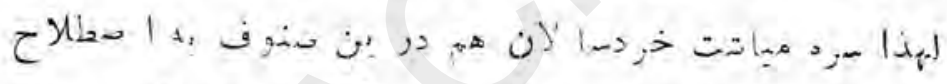

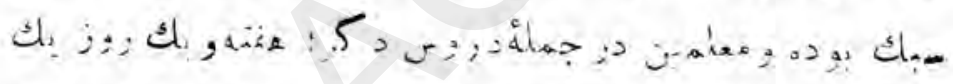

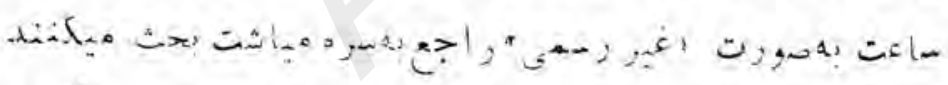

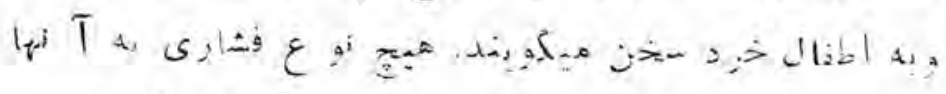

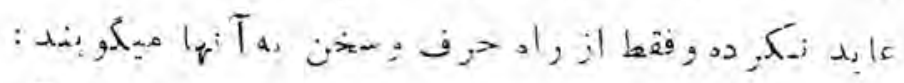

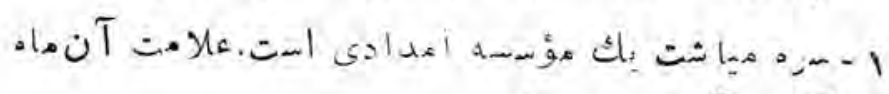

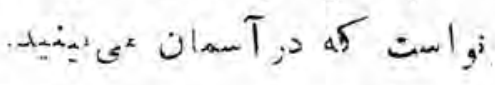

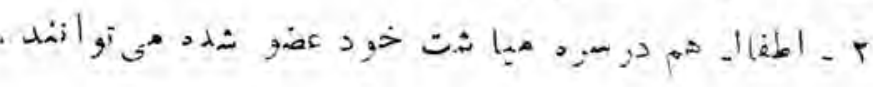

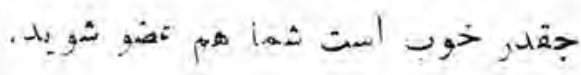


$\left(z^{*}\right)$

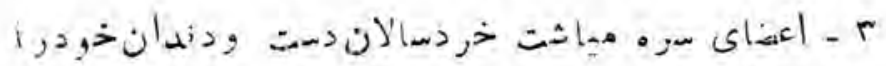

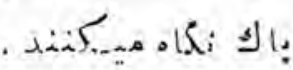

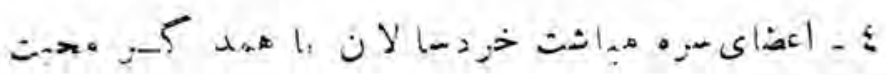

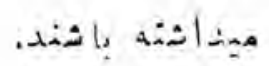

.

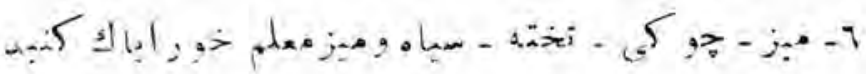

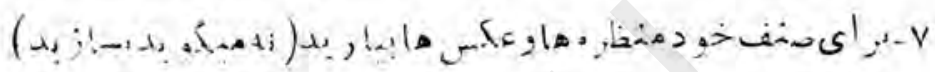

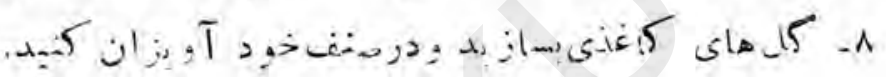

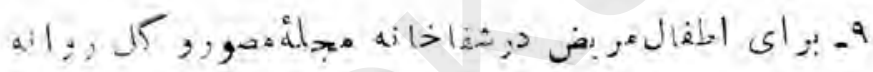

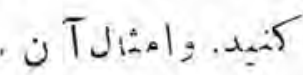

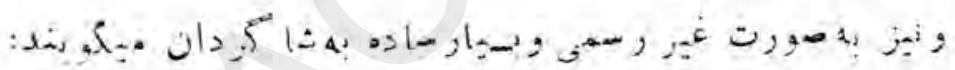

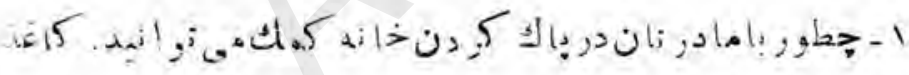

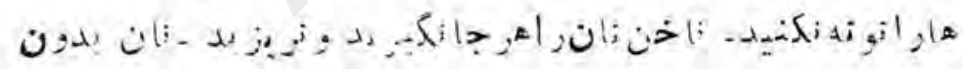

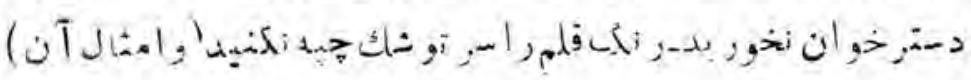

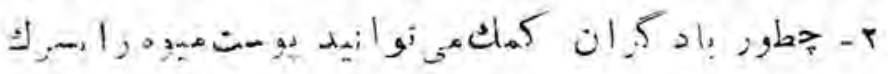

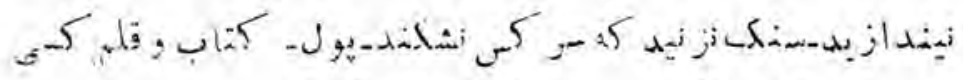

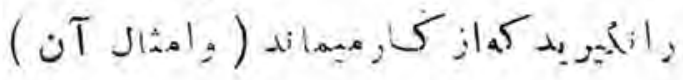

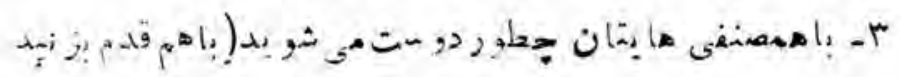


$(z r)$

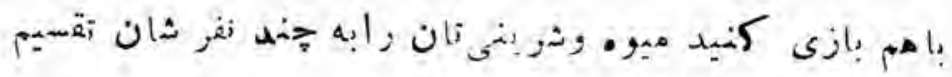

$$
(0, x, 4+5
$$

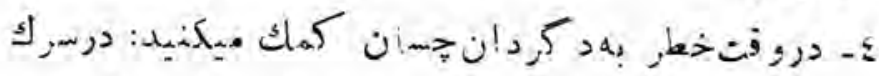

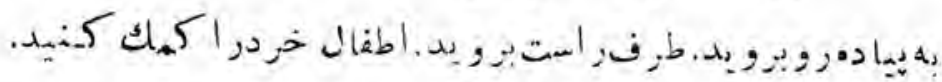

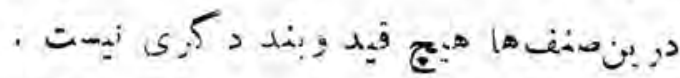

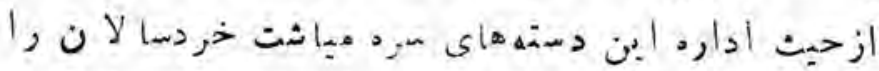

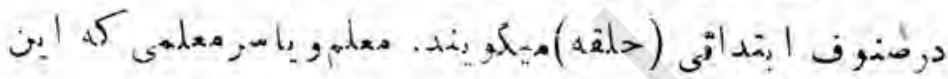

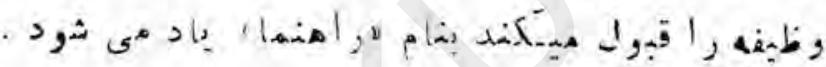

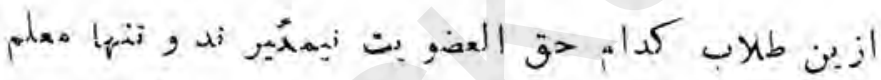

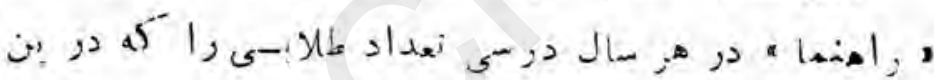

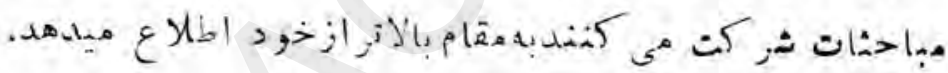

|

. bin

- مر صنوف بالانز

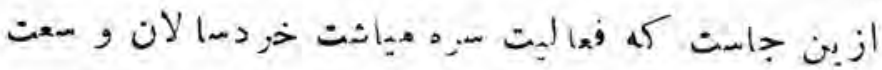

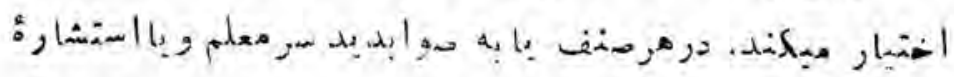

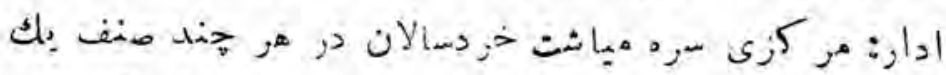

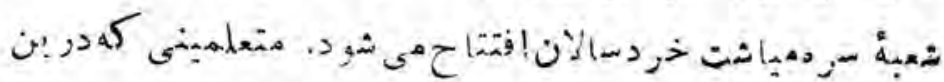


$(\because s)$

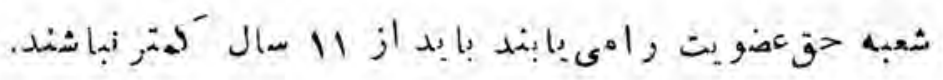

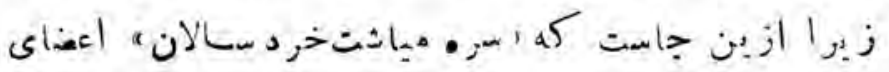

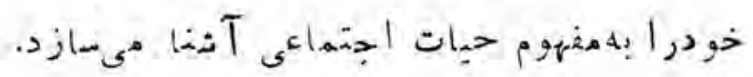

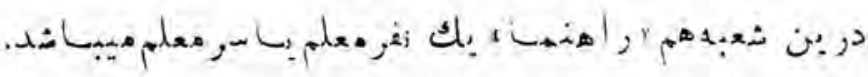

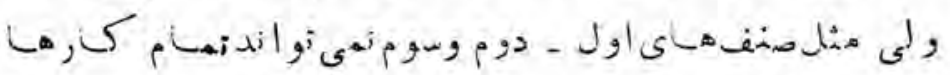

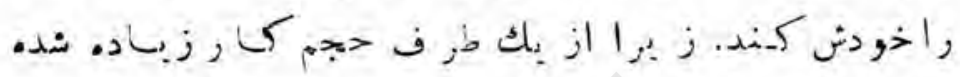

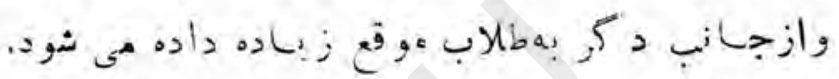

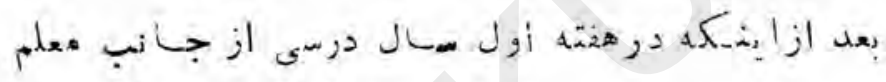

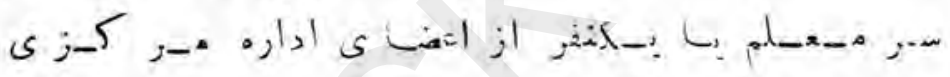

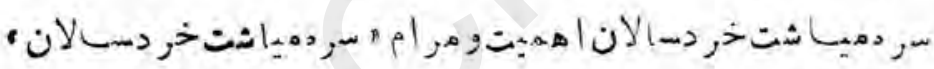

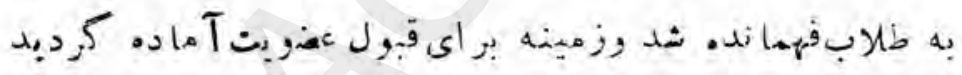

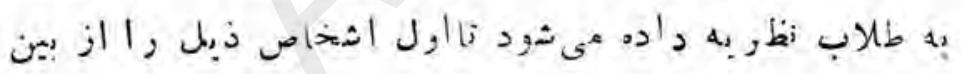

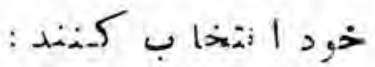
. -

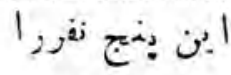

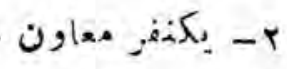

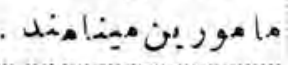

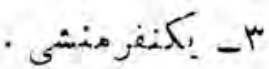

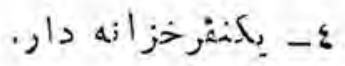

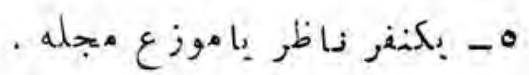


(₹०)

:

1

بد خهت

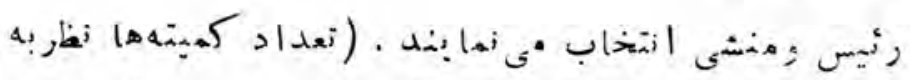

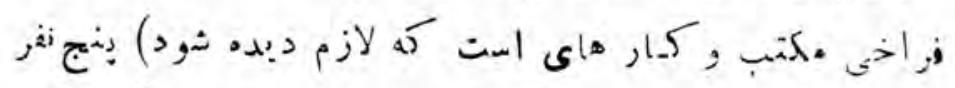

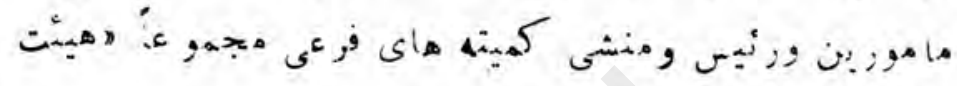

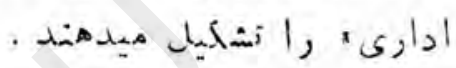

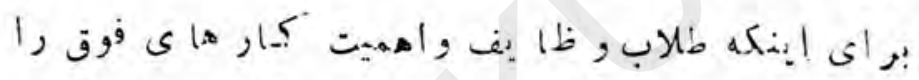

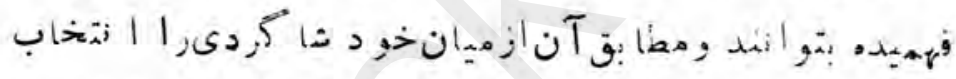

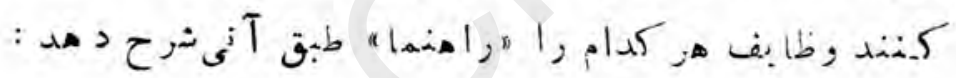

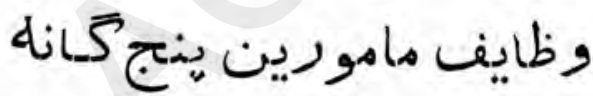

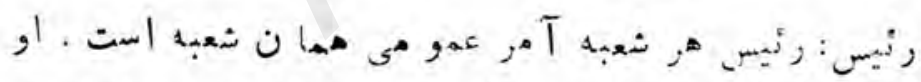

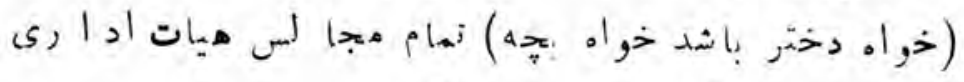

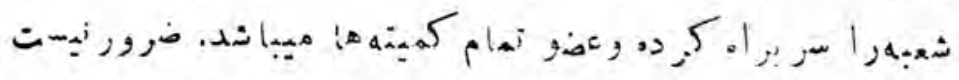

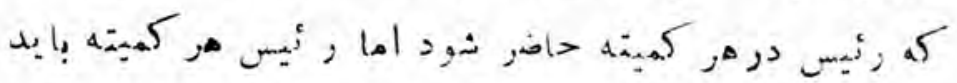

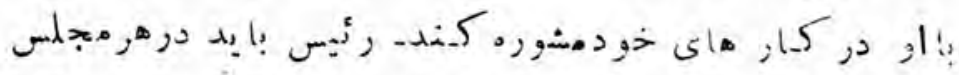

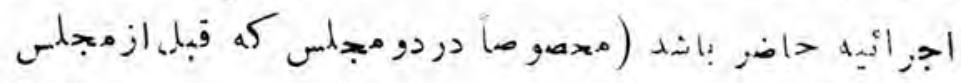

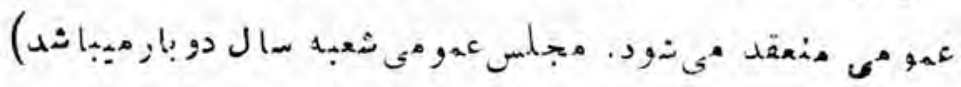




\section{$(: 1)$}

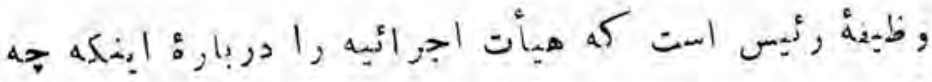

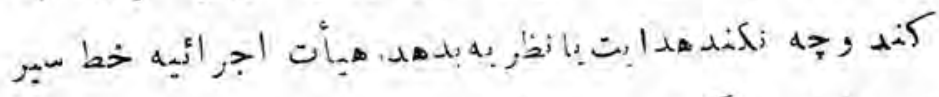

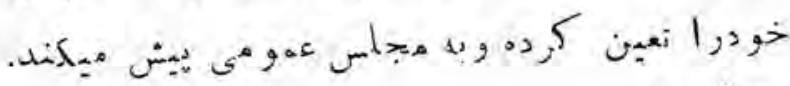

\section{مماون:}

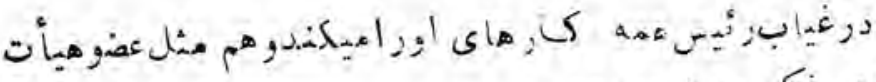

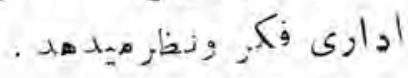

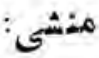

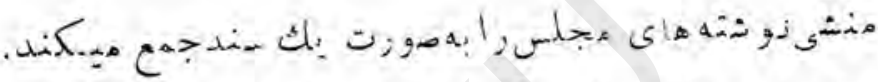
a

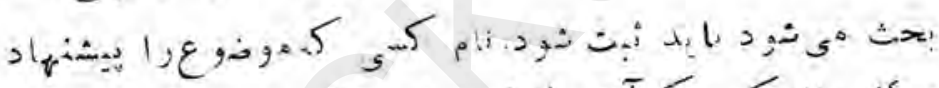

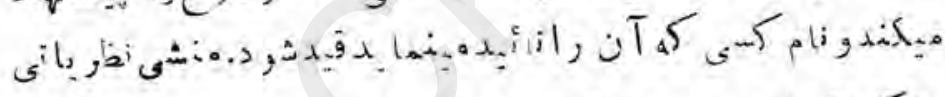

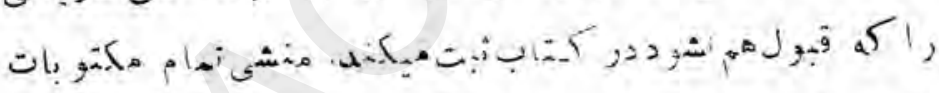

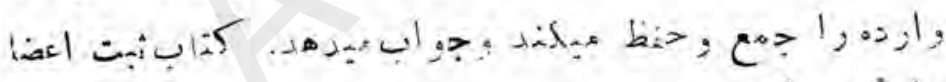

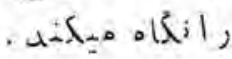

خزاز

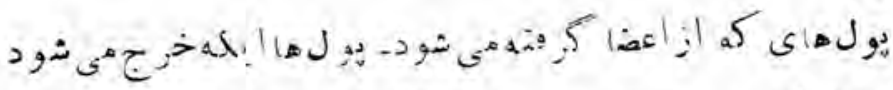
وبون كاك

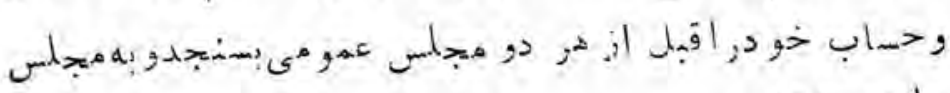
. 
(2v)

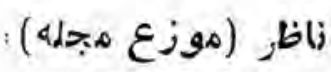

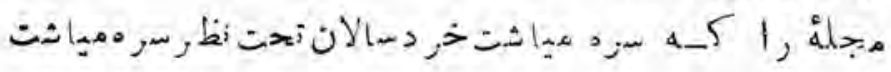

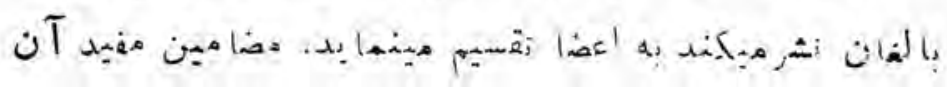

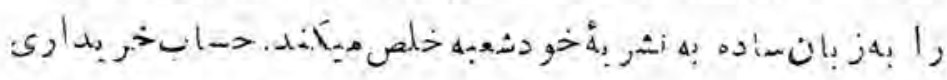

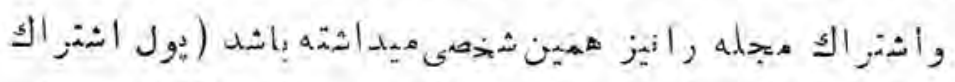
plaio

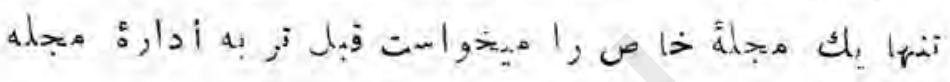

as 2 \&

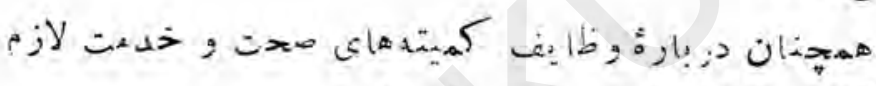

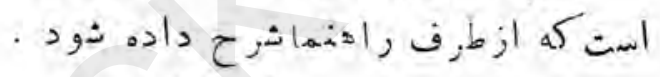
إن

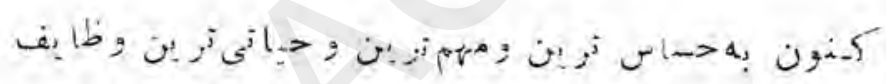

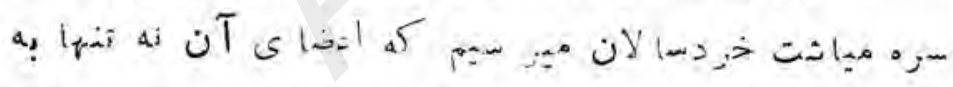

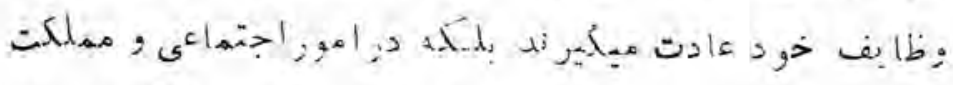

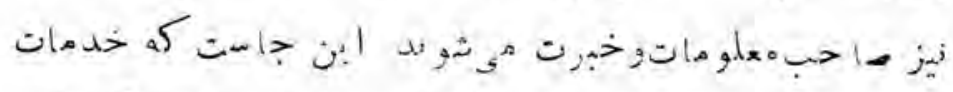

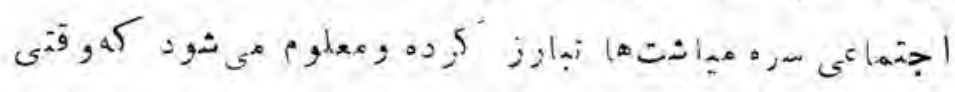

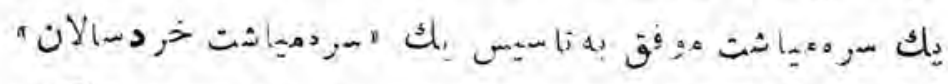

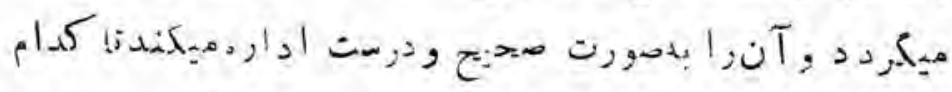

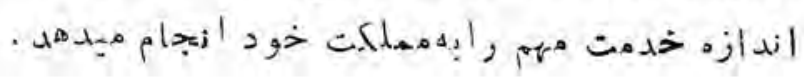




\section{(₹^)}

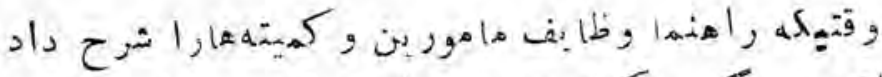

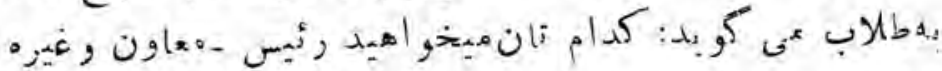

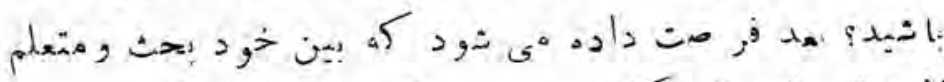

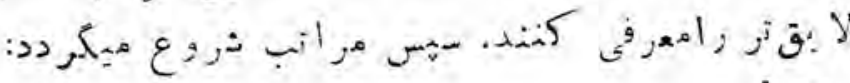

$$
\begin{aligned}
& \text { می1. }
\end{aligned}
$$

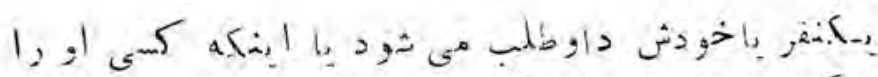

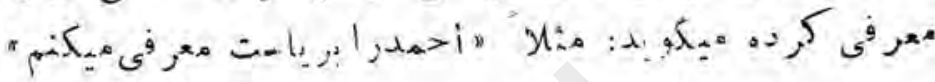
كرى

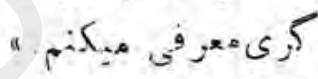

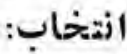

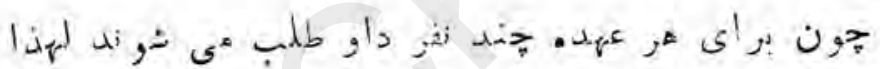

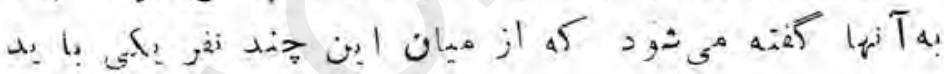

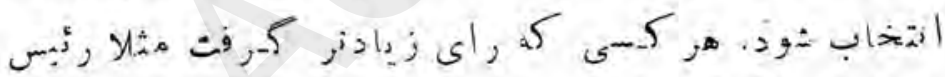

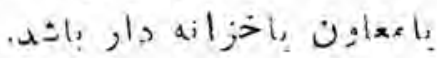

آن : قت

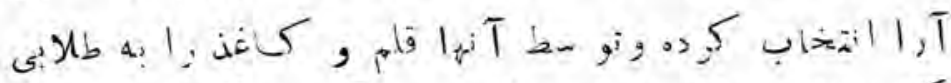

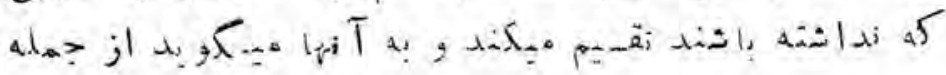

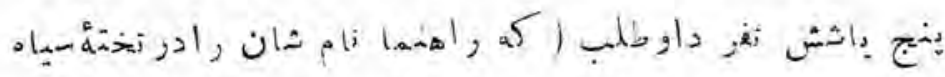

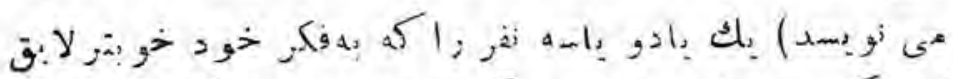

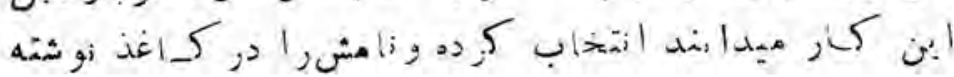




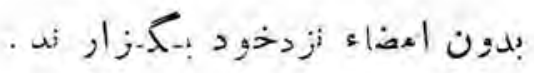
راى دهي:

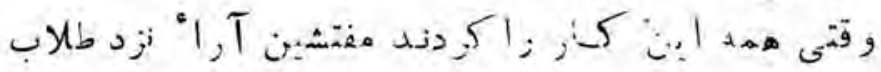

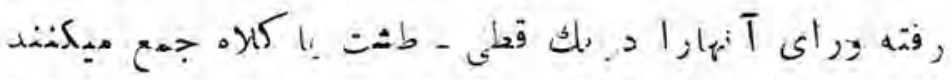

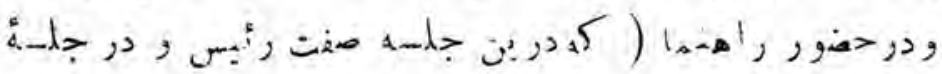

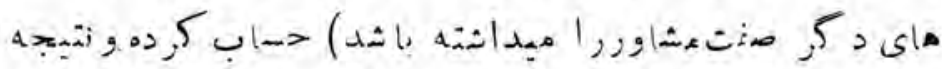

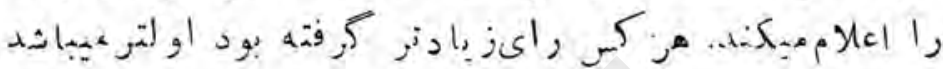

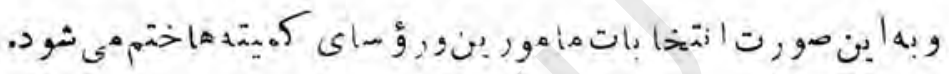

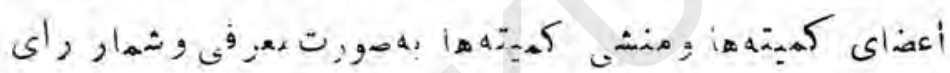

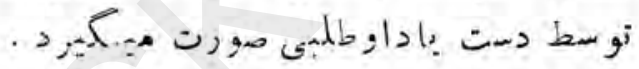

\section{كضو يت :}

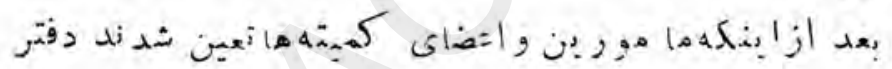

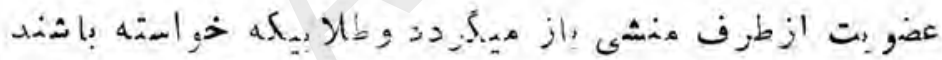

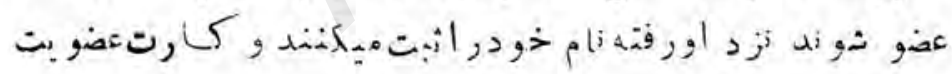

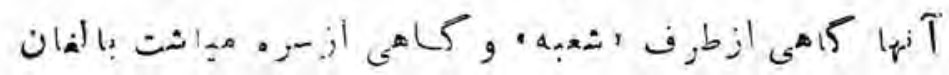

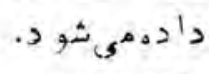
هolition

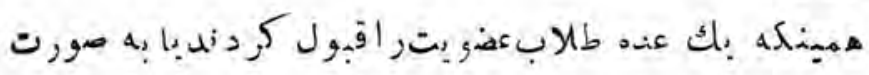

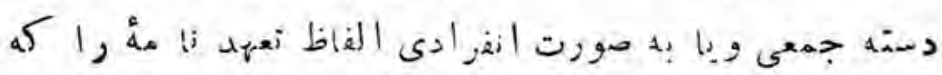

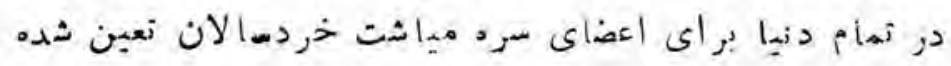


(o.)

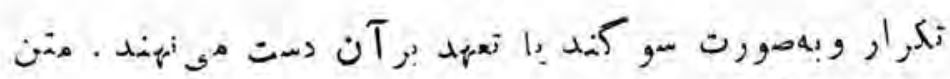

; تهد iامه ابن است:

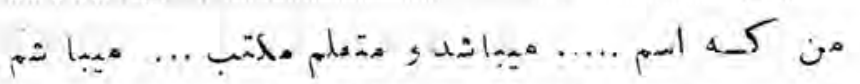

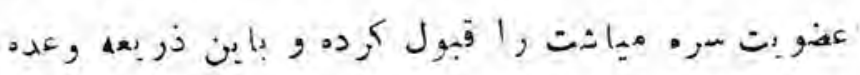

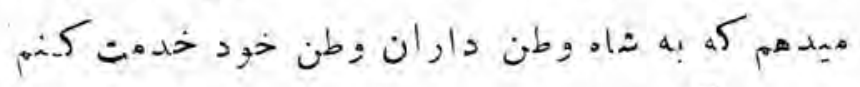

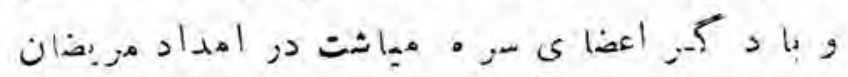

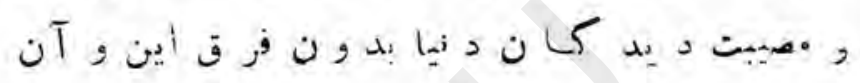

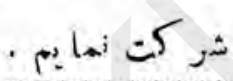

حن العضويث:

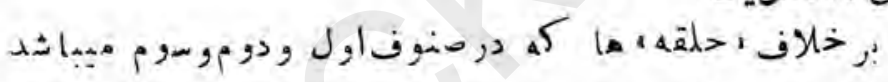

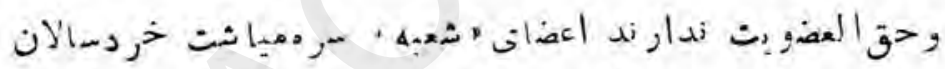

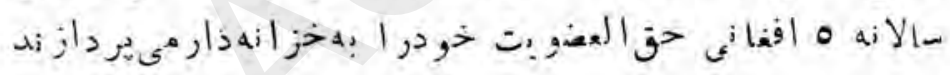

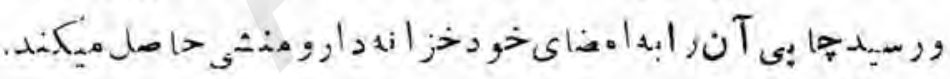

وظايف:

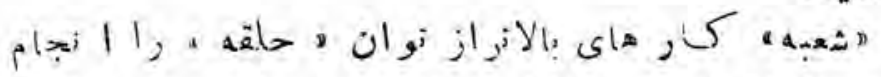

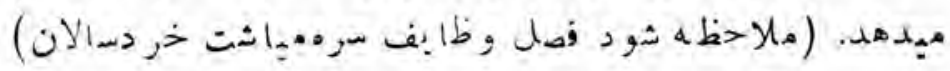

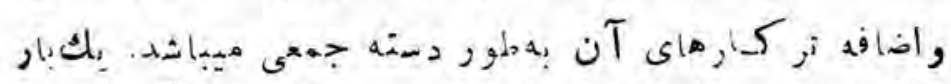

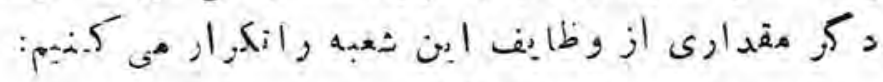

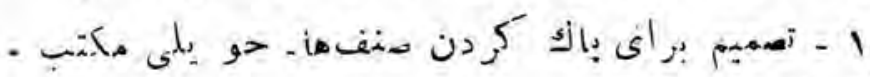

ميدانهاتى سيورت 
$(0,1)$

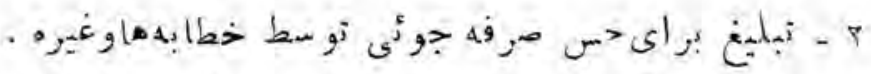

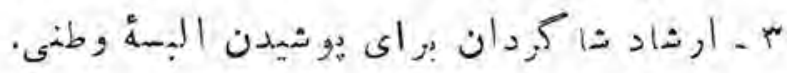

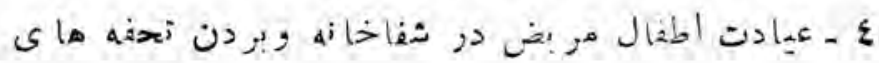

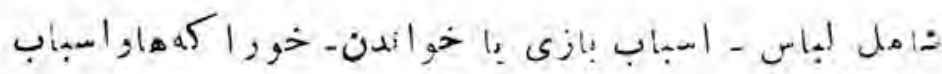

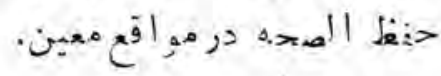

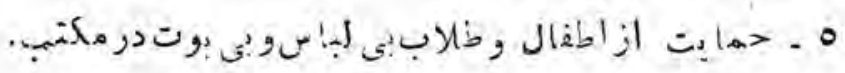
1

. ك

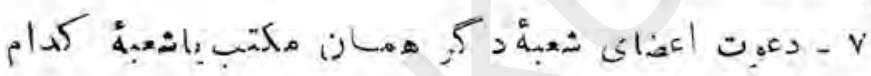

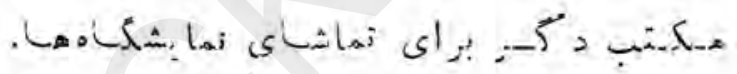

1 -

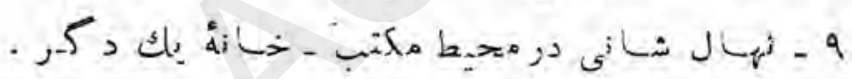

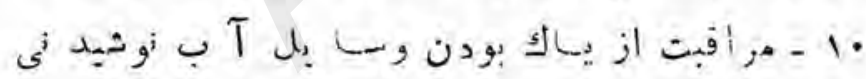

ه . 11

.كتب .

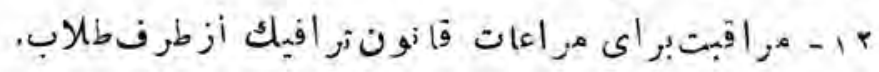

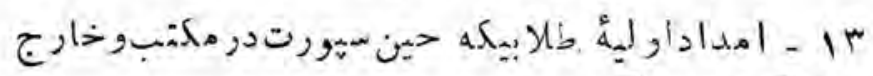

. 
$(\circ)$

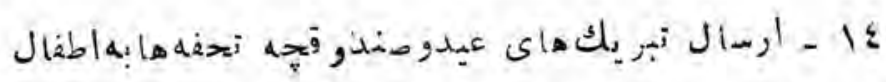

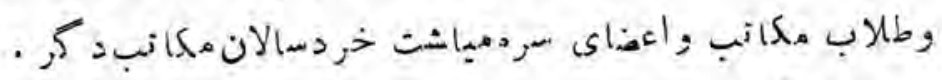

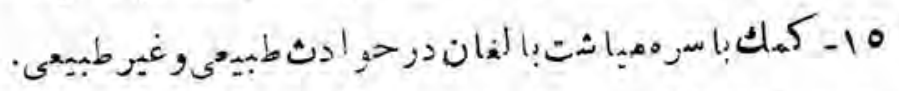

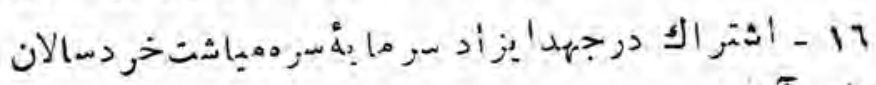

واهثال آن آن أن

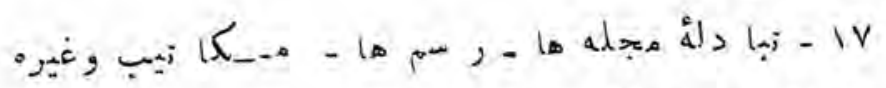

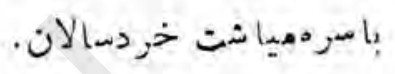

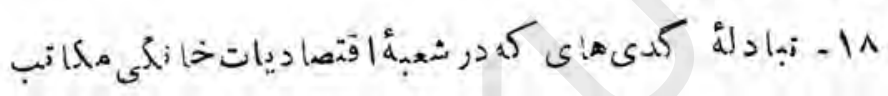

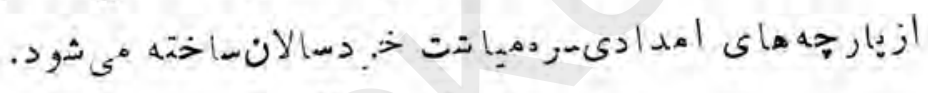

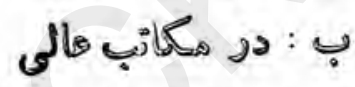

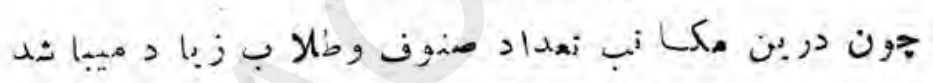

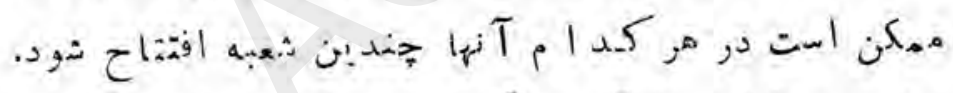

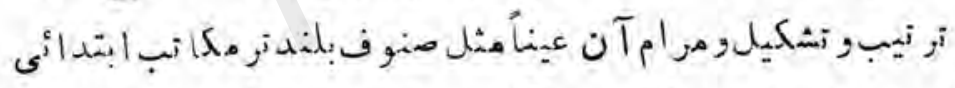

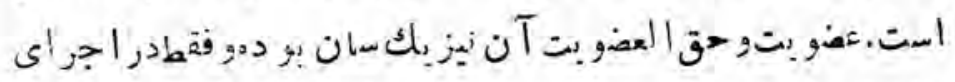

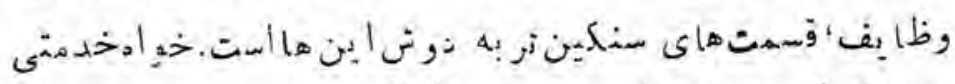

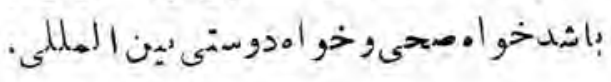

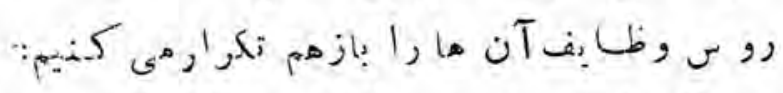

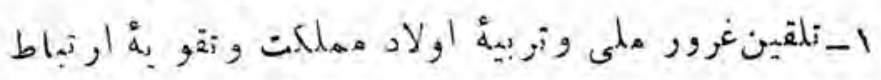

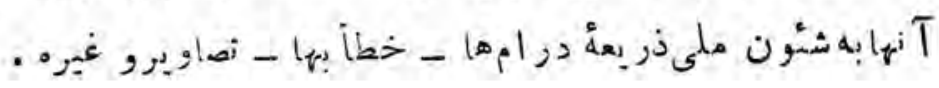


(or)

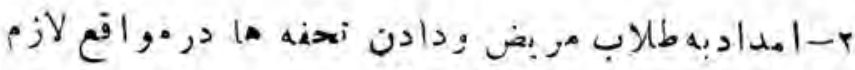

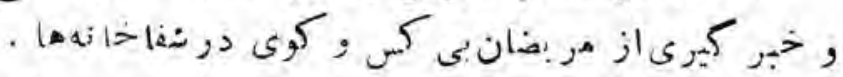

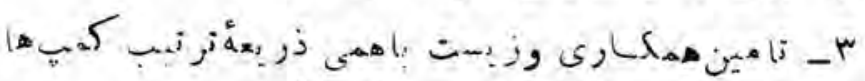

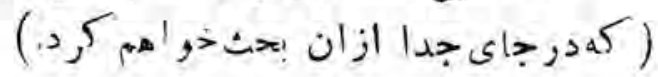

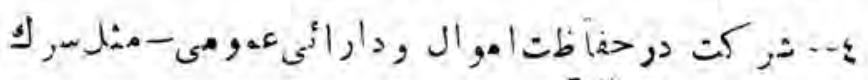

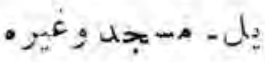

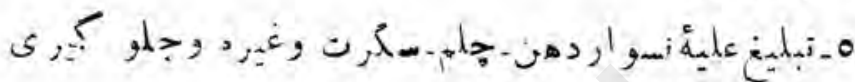

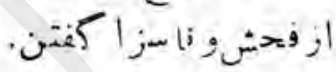

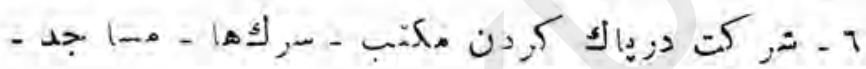

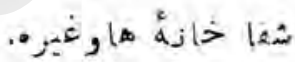

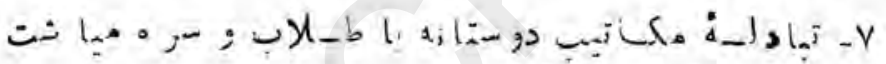

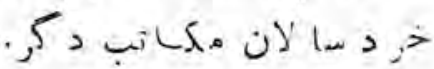

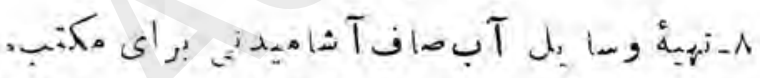

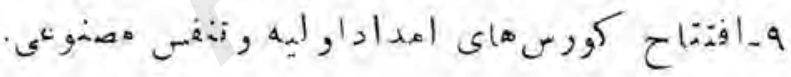

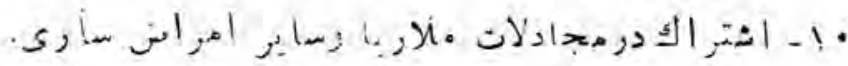
11 . A

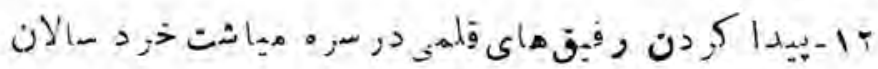
Sto.0, $5=$

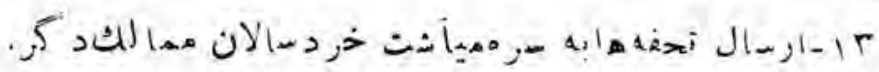


$(02)$

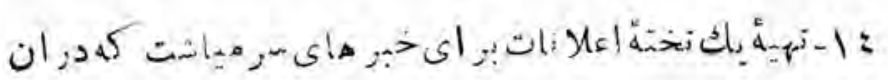

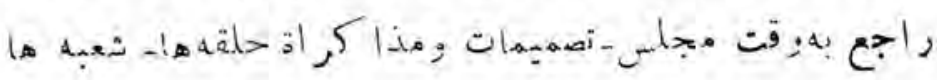

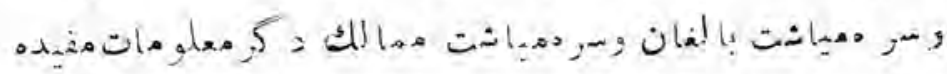

.29 ش ش

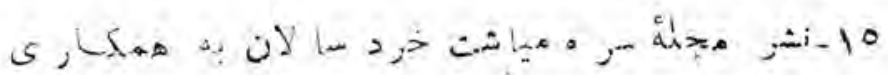

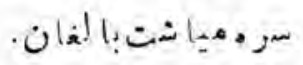

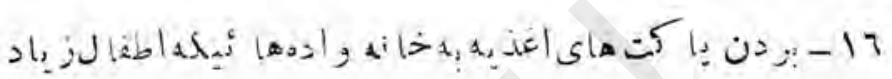

$.2 j, 12$

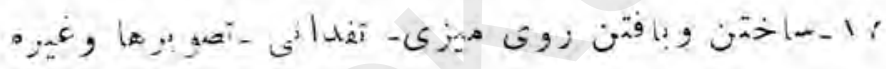

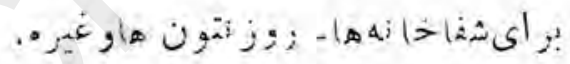

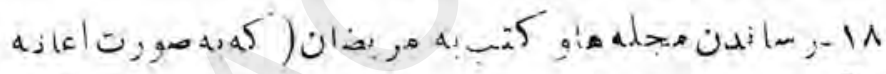

(.

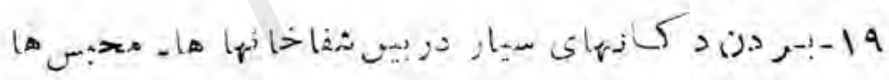

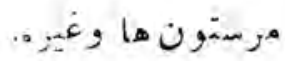

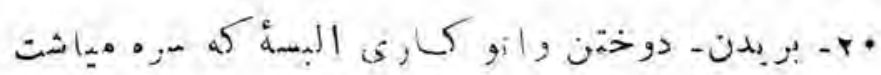

a

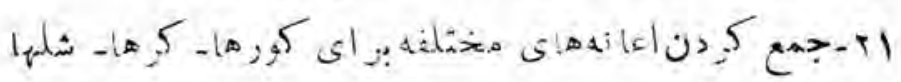

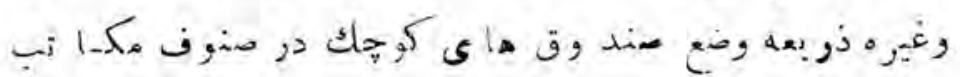

0,0 , 
$(00)$

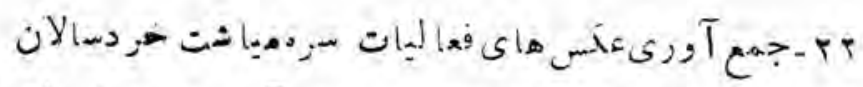

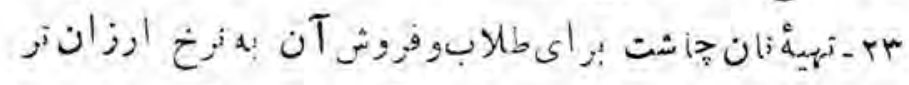

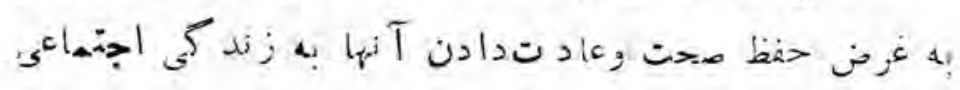

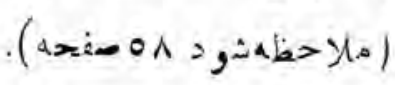

.

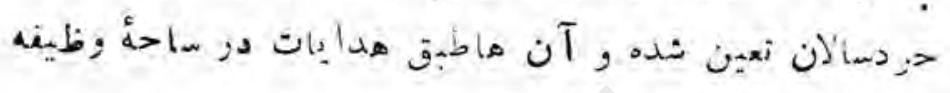

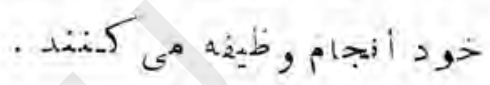
مسئو إيت هاى ادادارى:

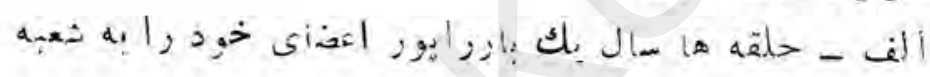

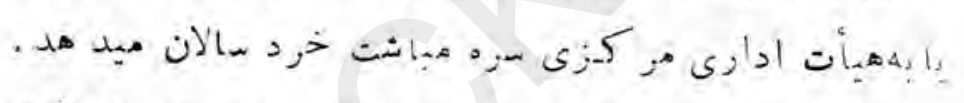

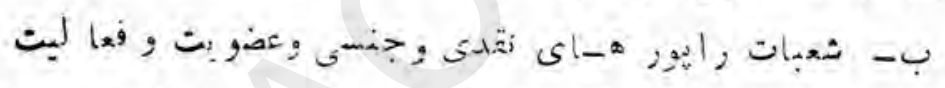

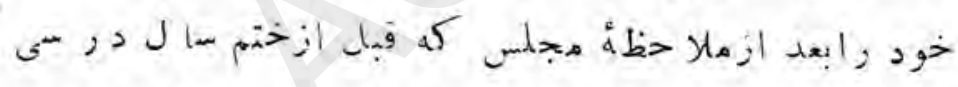

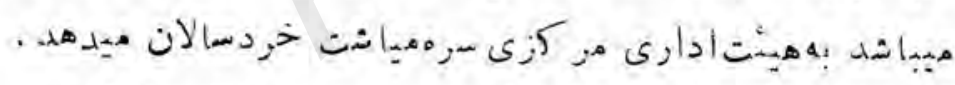

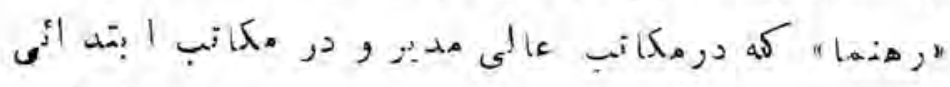

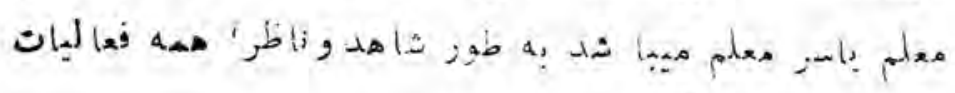
(1) تبصر :

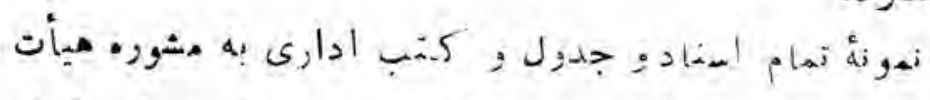

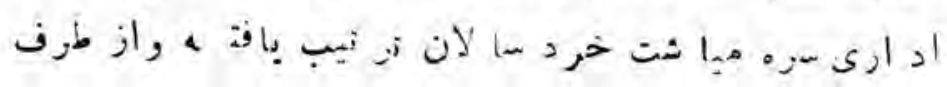


$(c 7)$

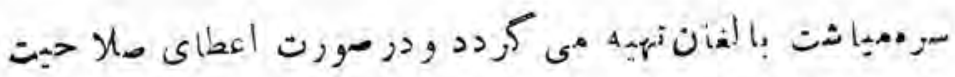

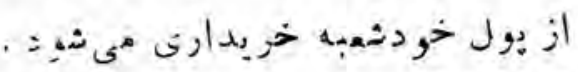
تبصرة مدوم:

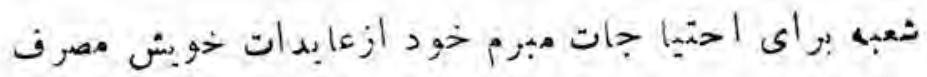

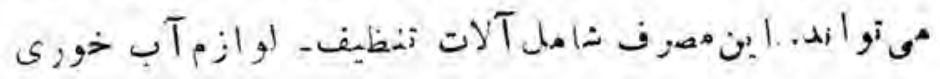

.

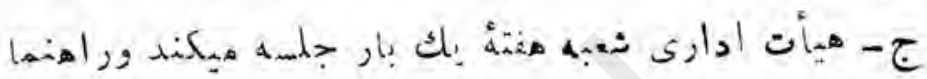

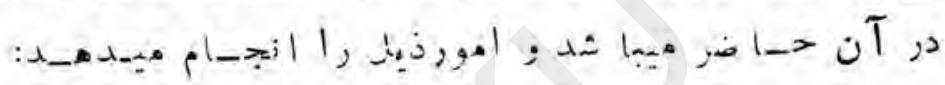

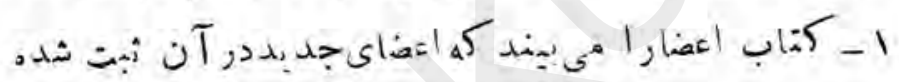

:

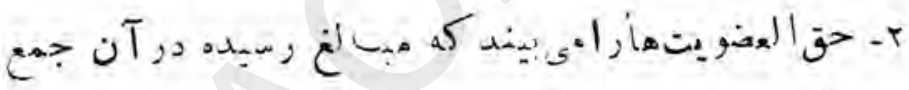

ה A

تش $A_{-i} C_{\text {C }}$

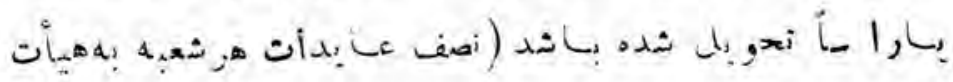

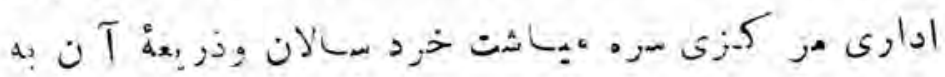

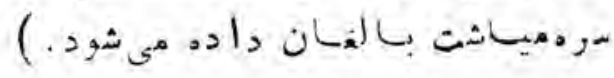

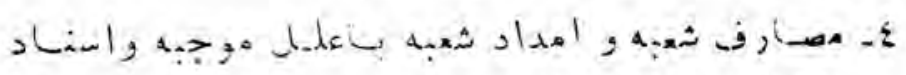
T 
(ov)

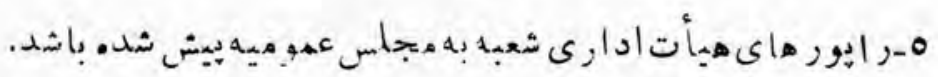

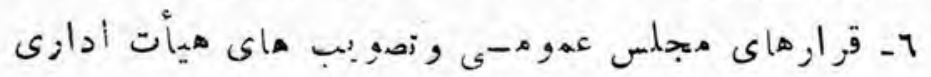

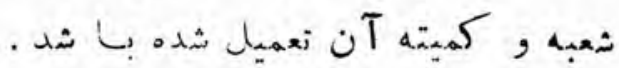


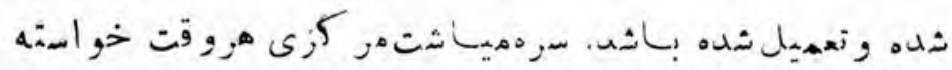

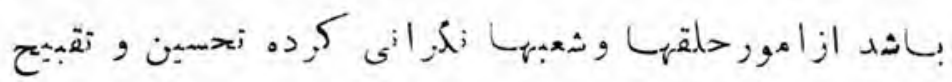

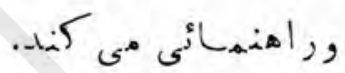

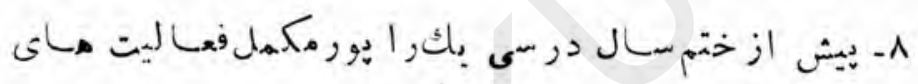

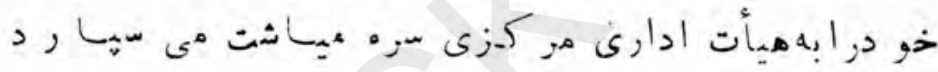

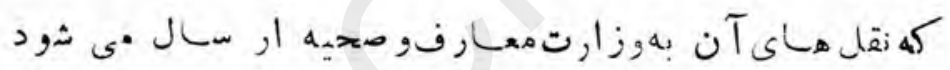

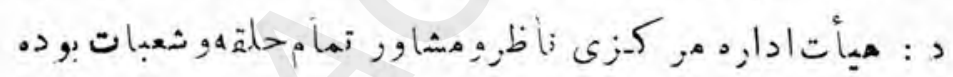

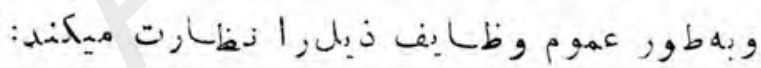

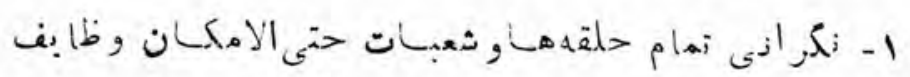

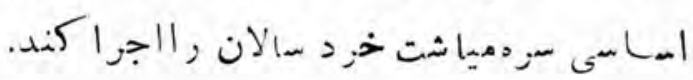

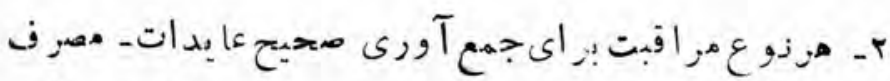

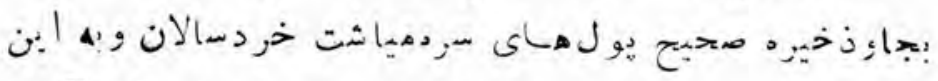

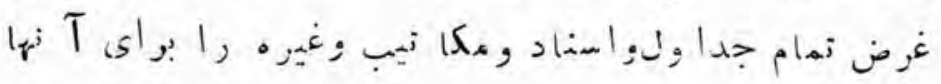

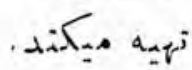


$(O N)$

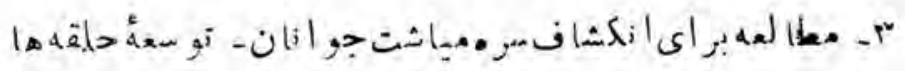

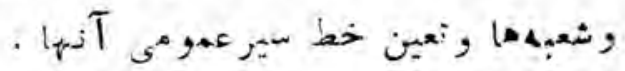

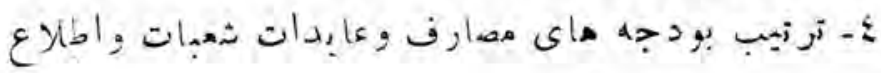

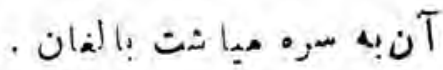

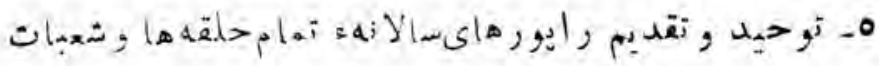

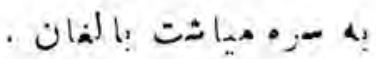

تشآنا

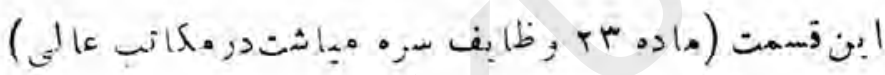

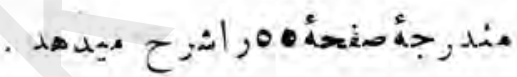

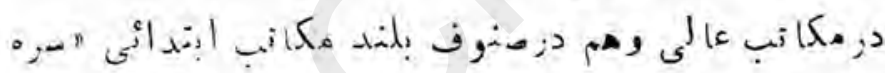

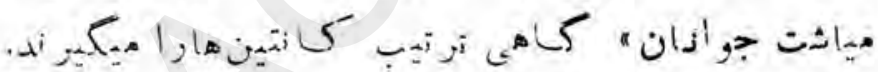

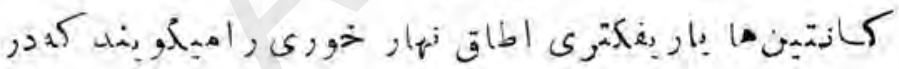

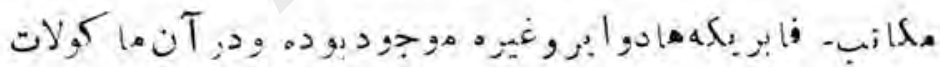

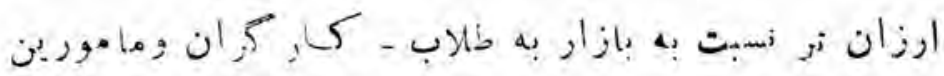

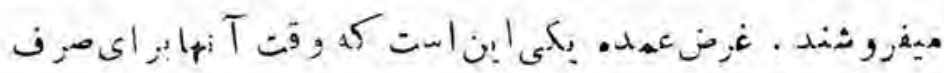

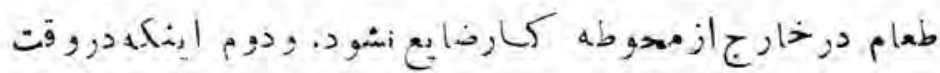

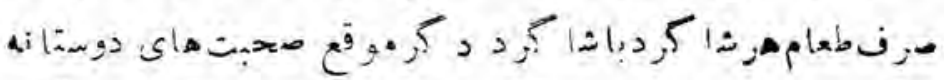

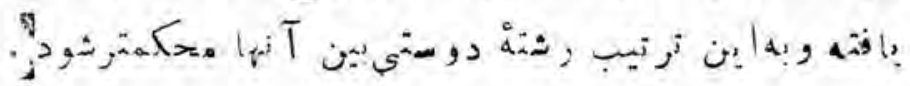




\section{(oq)}

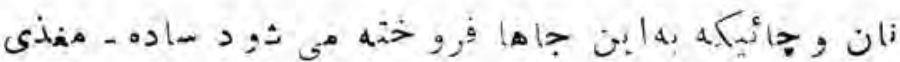

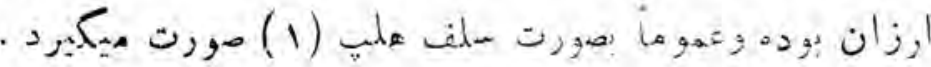

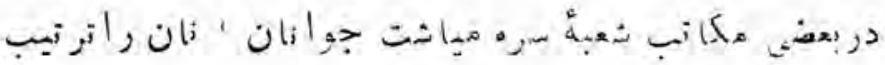

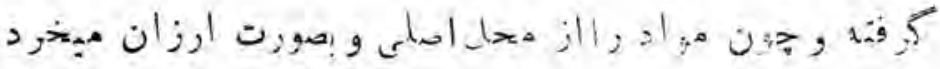

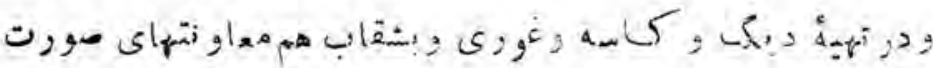

ميكير 2.

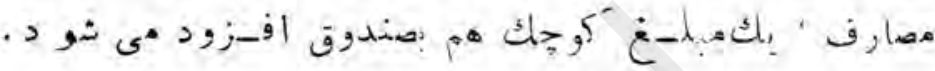

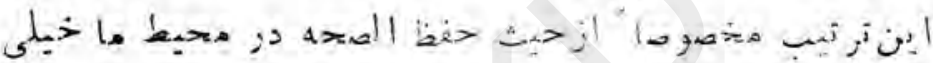

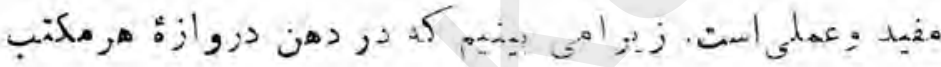

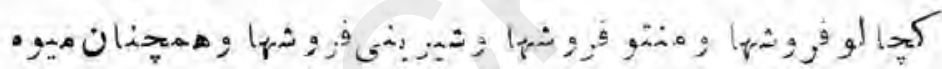

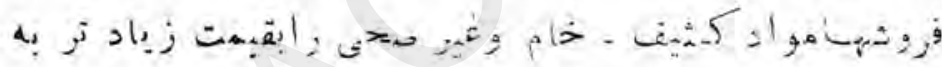

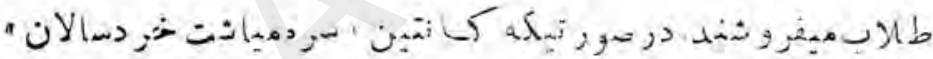

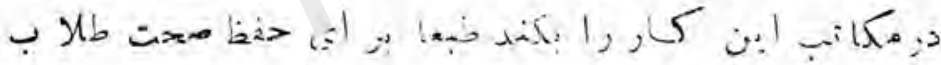

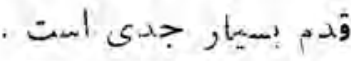

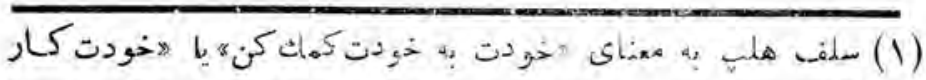

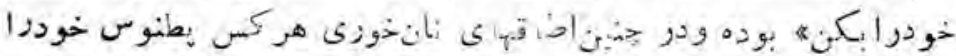

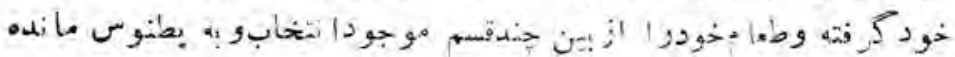

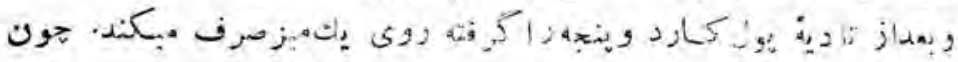

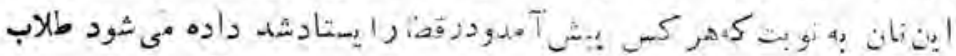

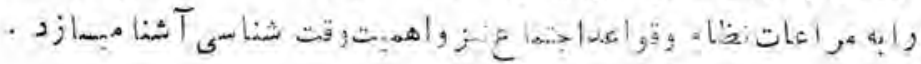




$$
\text { (1.) }
$$

ورى

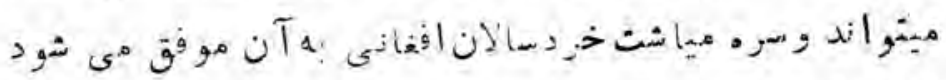

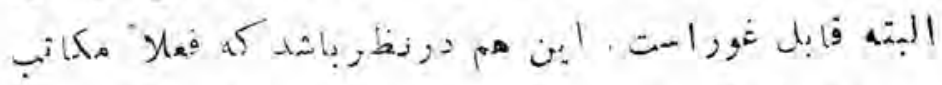

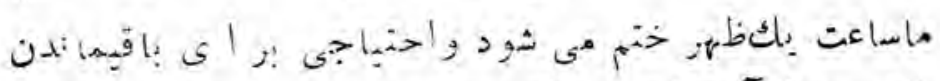

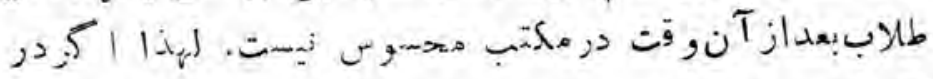

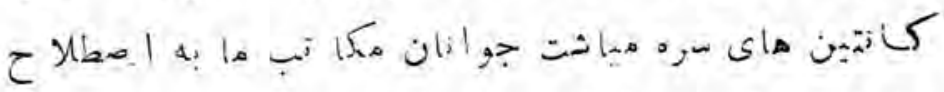

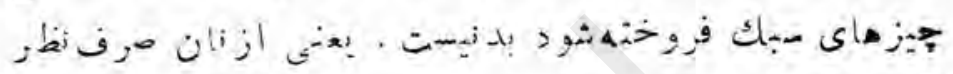
كر 52

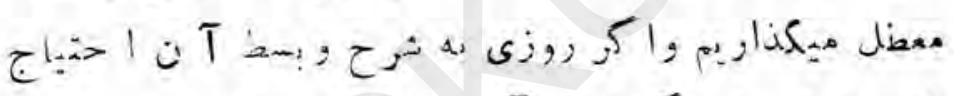

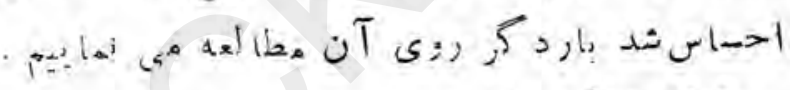
هينت م:أ و ورتى

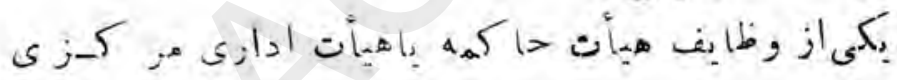

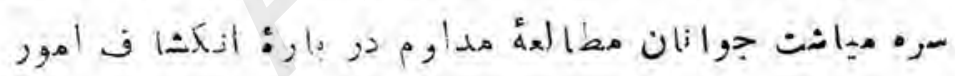

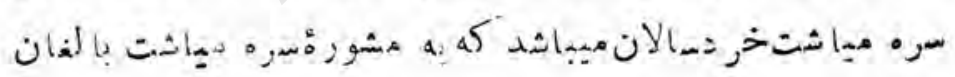

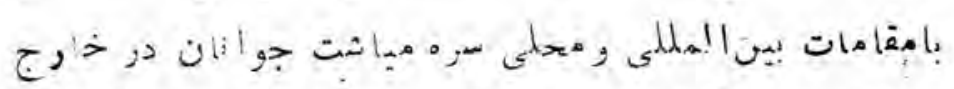

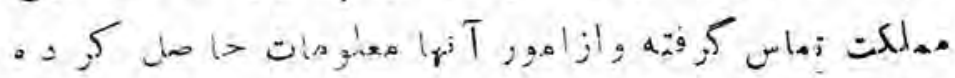

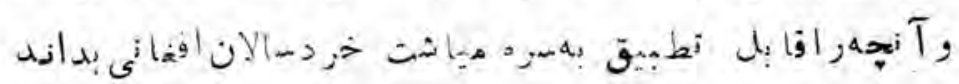

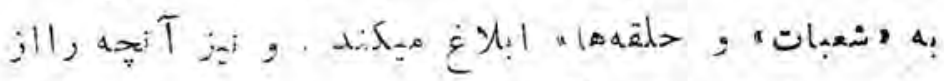
: 
$171)$

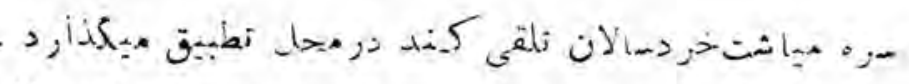
إن .

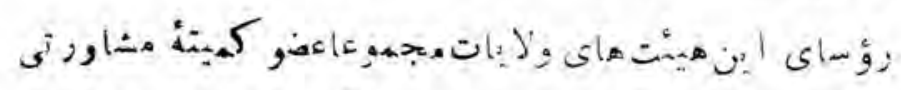

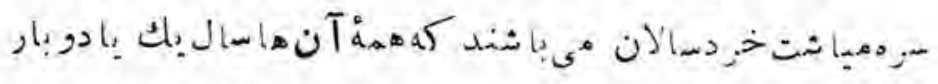

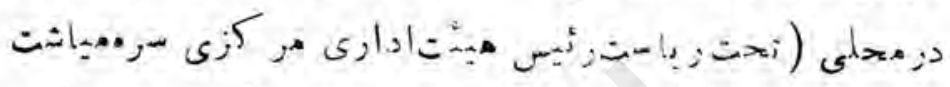

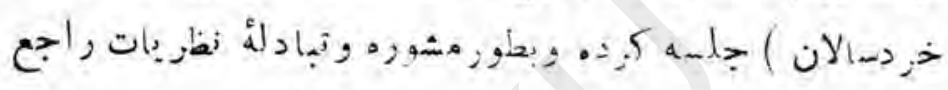

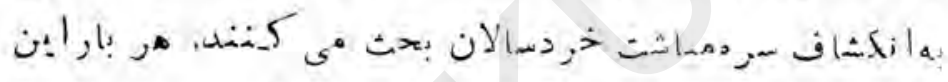

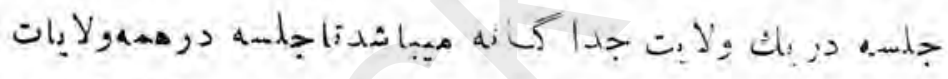

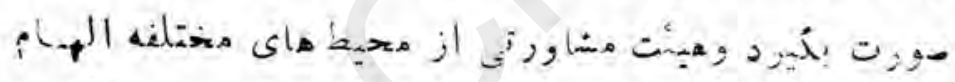

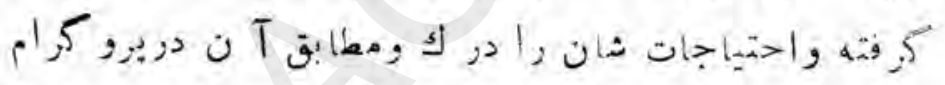

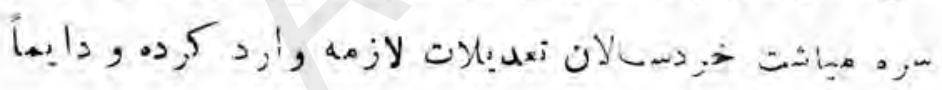

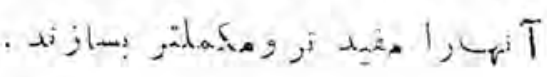
( ) , كان-

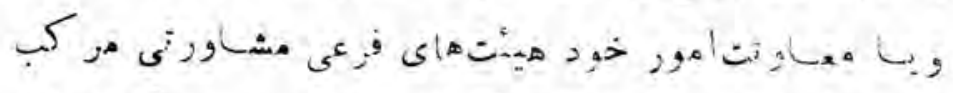

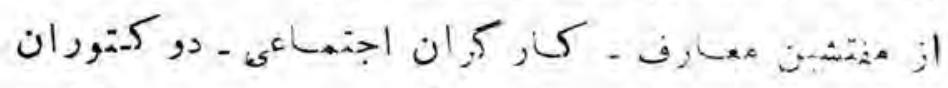
ن 


\section{(ir)}

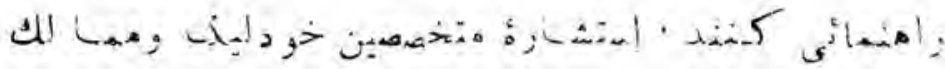

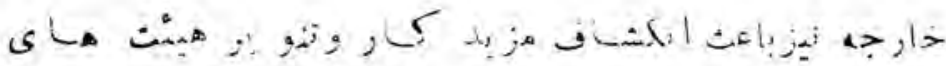

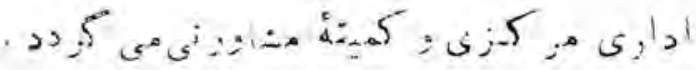

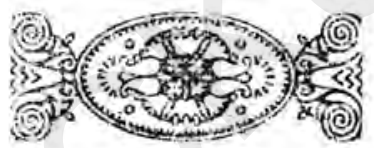


$(\pi r)$

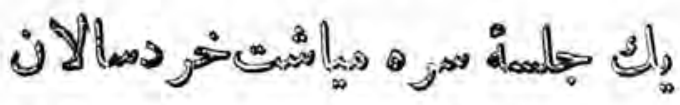

بطورمثال

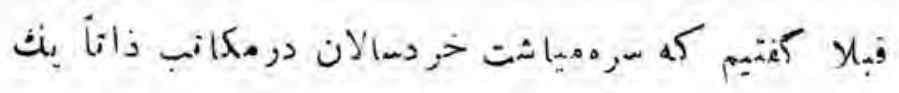

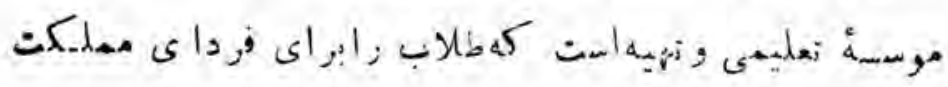

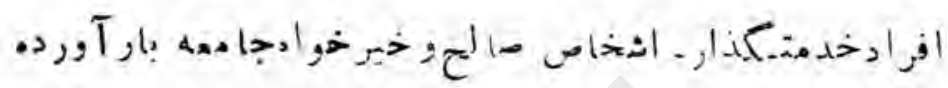

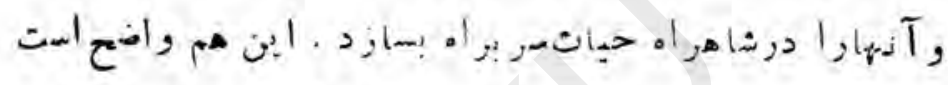

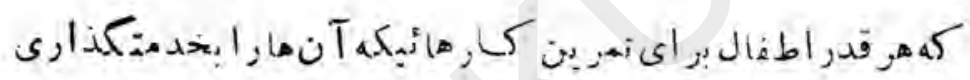

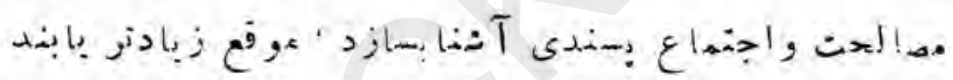

:

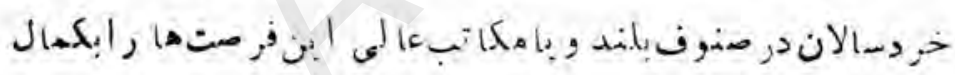

خو بى وزحت نظام بس هفيد نهيه ميلند وطلاب زعد از خامل

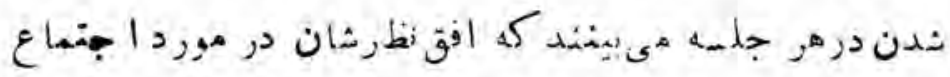

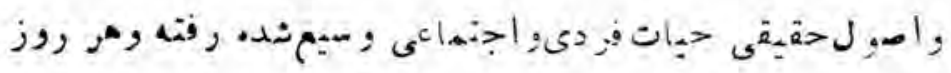

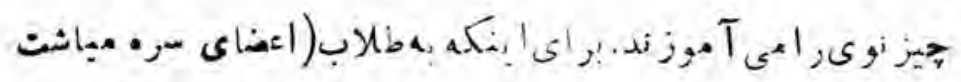

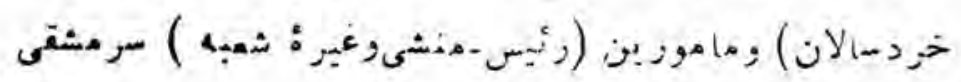


$(1 z)$

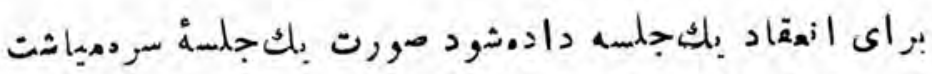

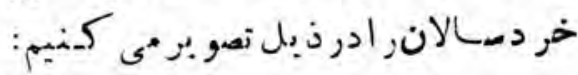

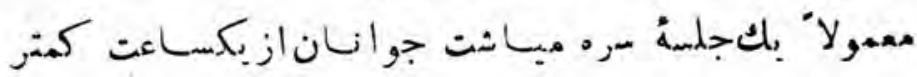

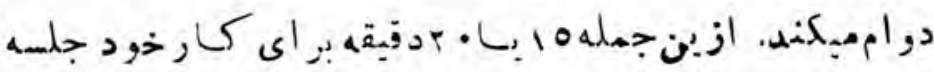

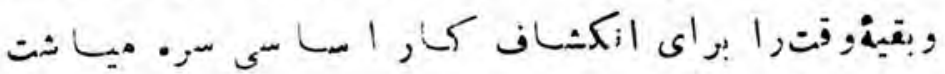

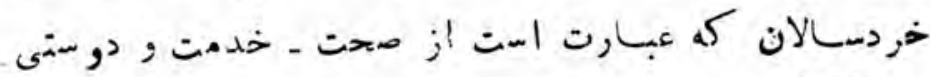
بن الهن الملى تخصبص ميدهند

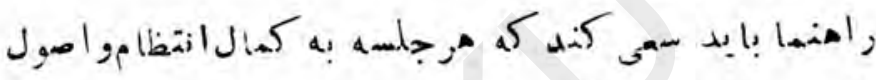

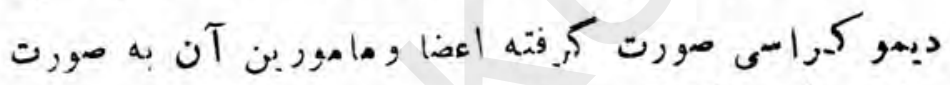

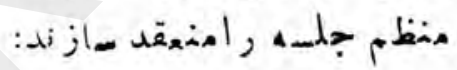
رنبس دزجو كى خود نشسته آجندة مجلم وسا بر اسناد او

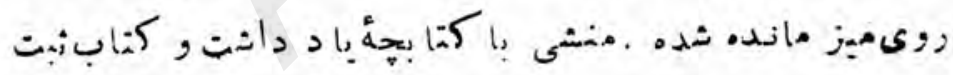

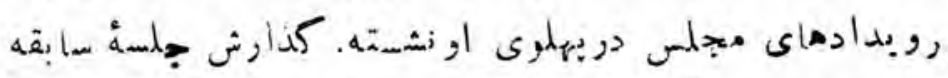

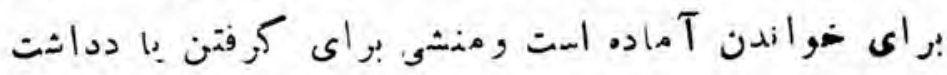

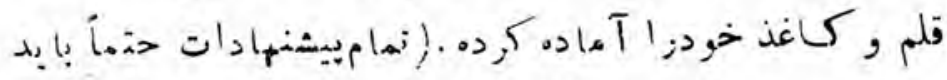

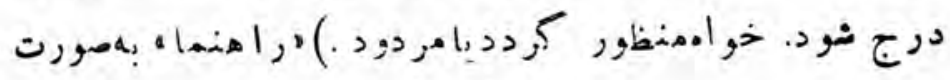

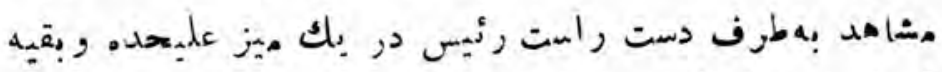

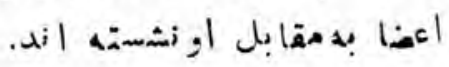


(7o)

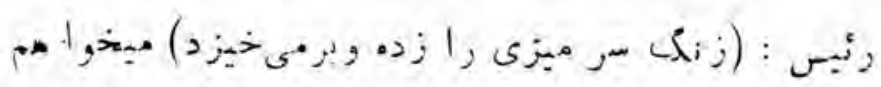

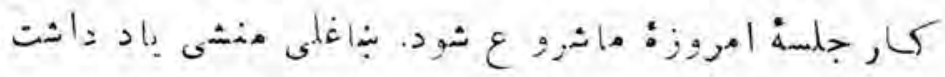

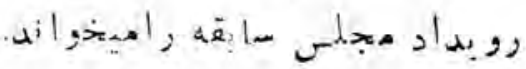

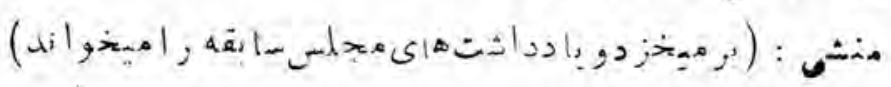

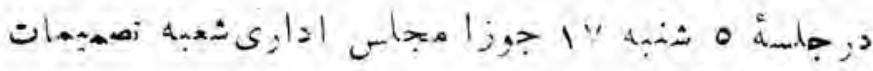

$\therefore 2,5, \dot{x} i \mid 1,1, j$

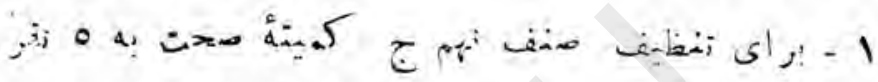

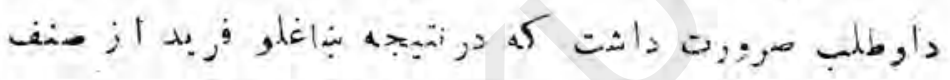

نهand

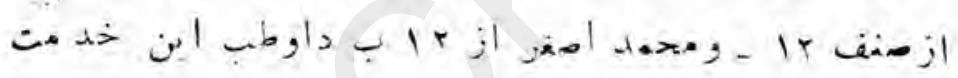

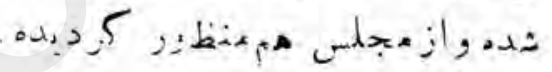

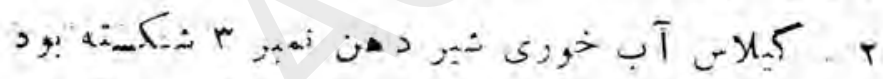

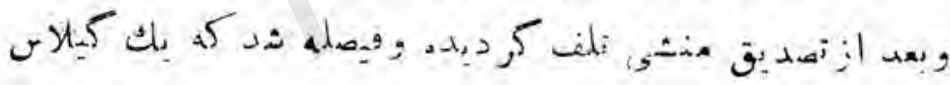

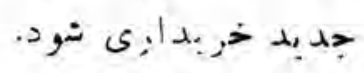

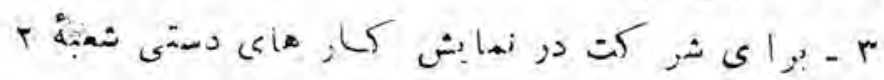

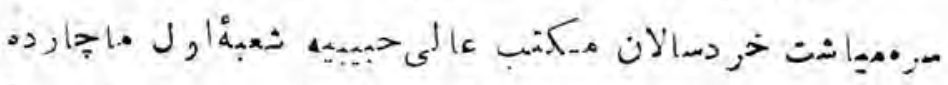

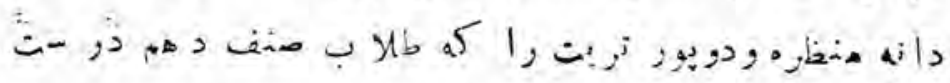

.

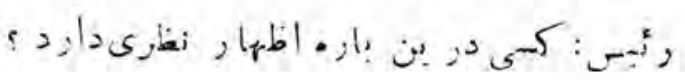


$(7)$

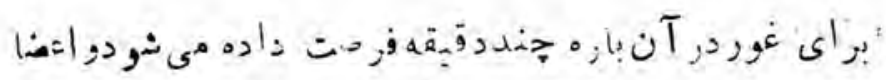

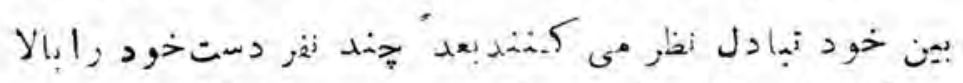

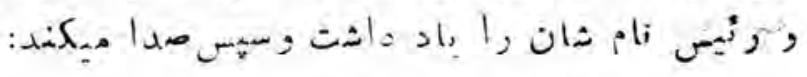

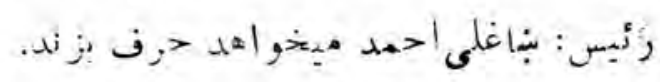

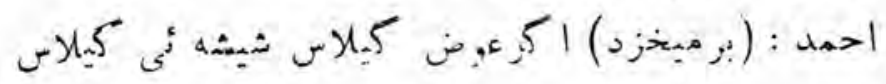

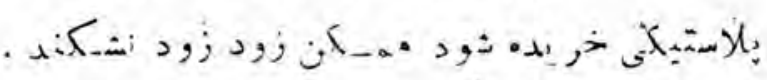

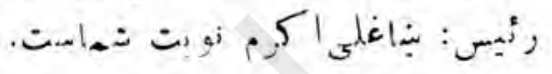

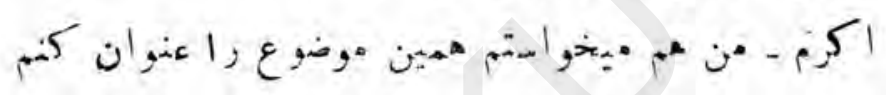

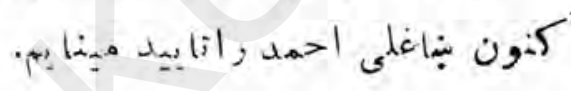

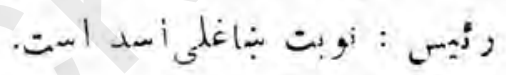

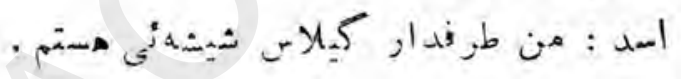

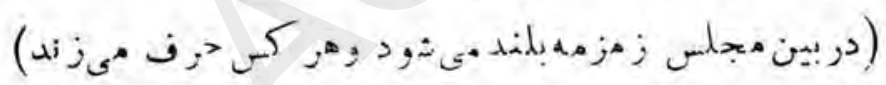

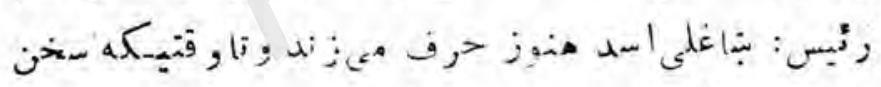

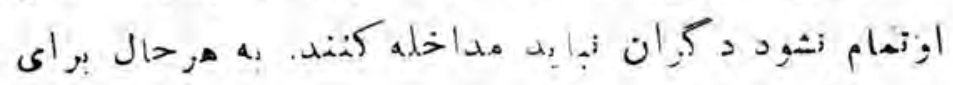

1

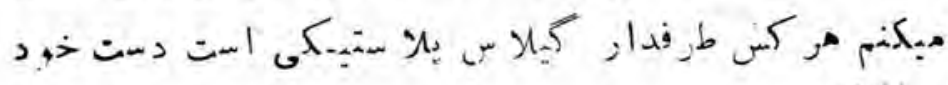

, إ.

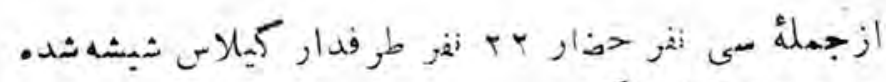

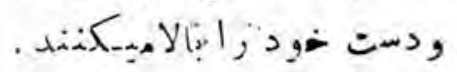


$(7 v)$

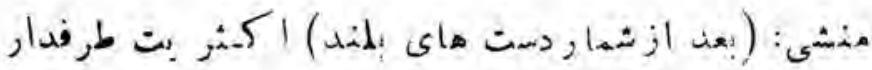

. Ail

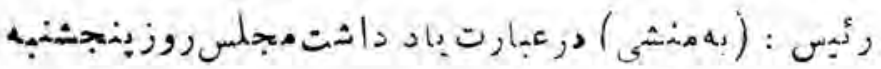

IV

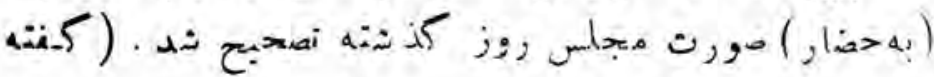

وآنر آ آ

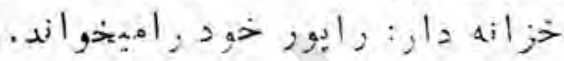

غ.

ixhis

$2,2^{15}$

jilil).. •

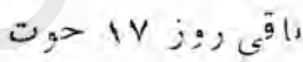

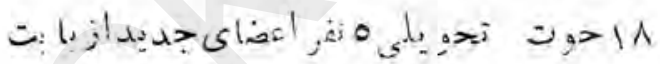

ro enter

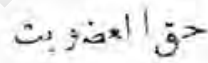

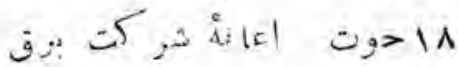

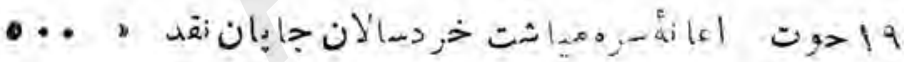

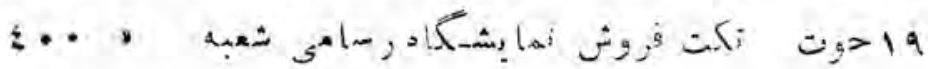

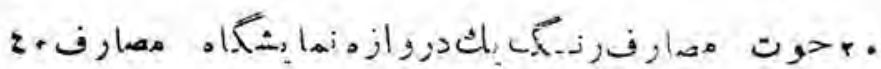

•

rq.

גilutai

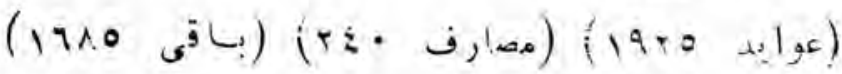

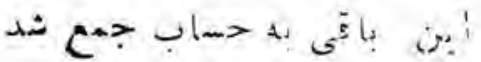


(41)

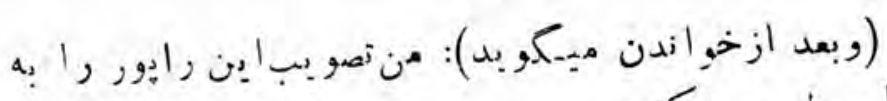

مجلس طرح ميـكنم:

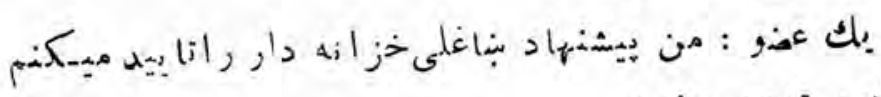

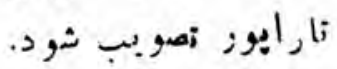

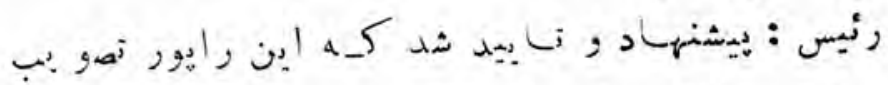

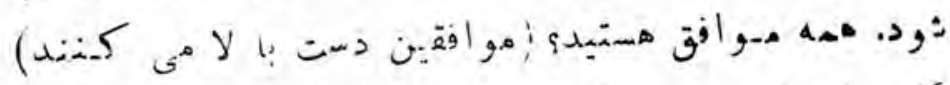

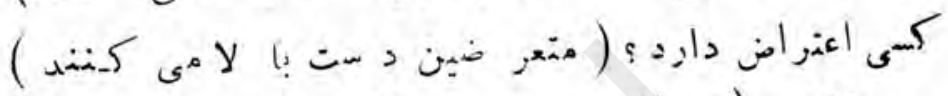

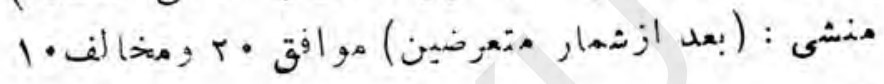

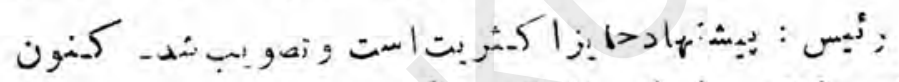

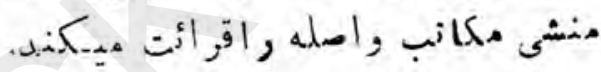

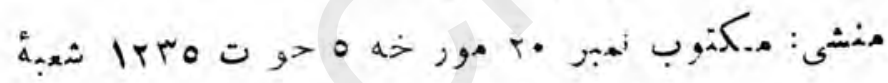

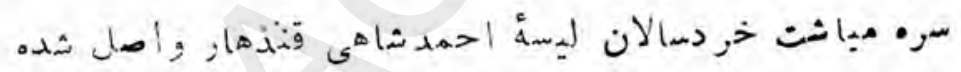

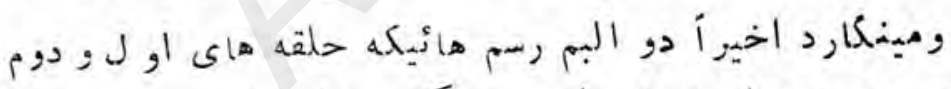

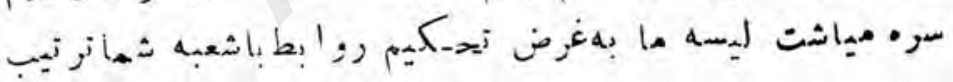

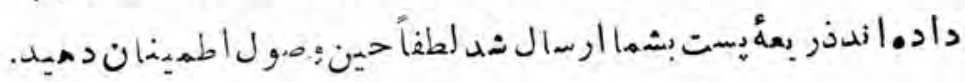

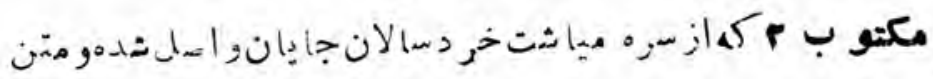

آن قرار ذيل است ابه

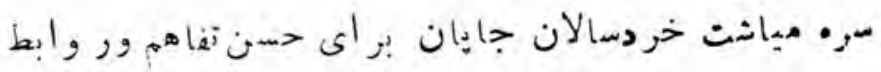

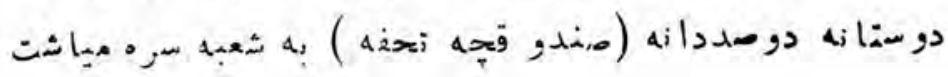


(79)

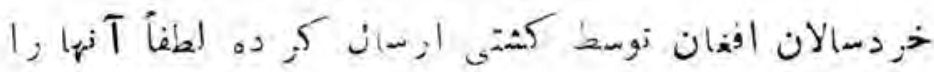

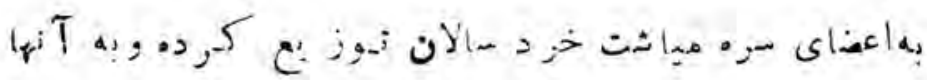

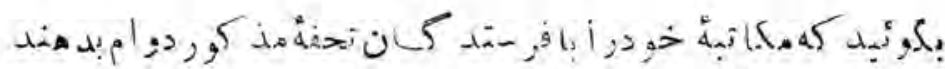

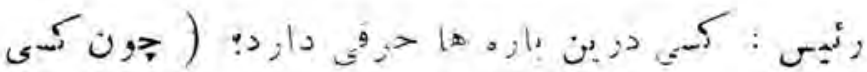

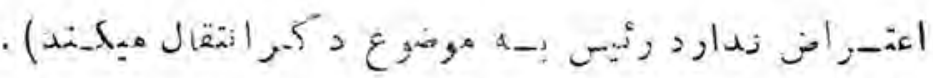

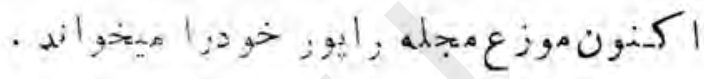
: al

عابدات مصارف : باتى ثهارة

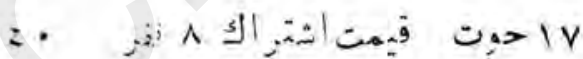
O:

1.

$\circ$ lils, ,

10 $9:$

101

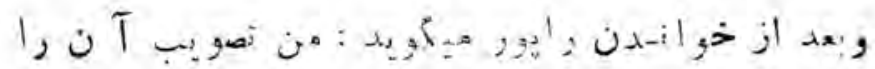

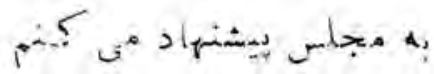


$(v \cdot)$

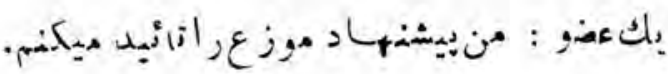

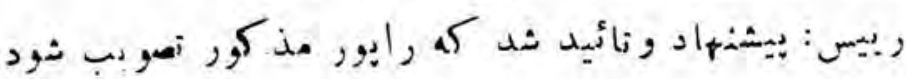

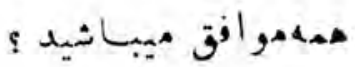

منشى :متعزض دوبد نميشود .

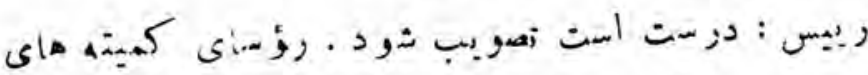

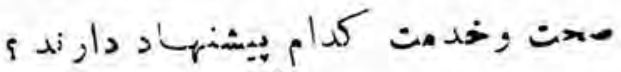

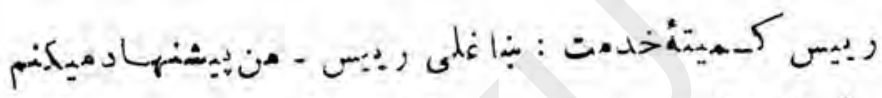

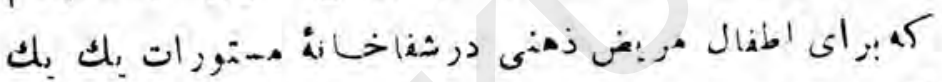

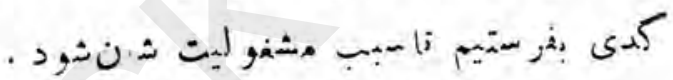
.

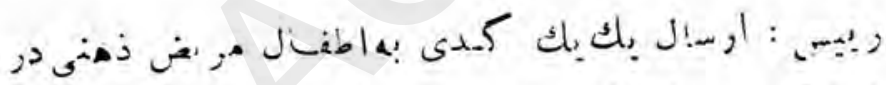

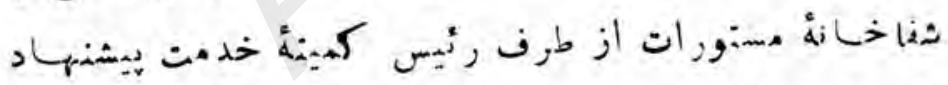

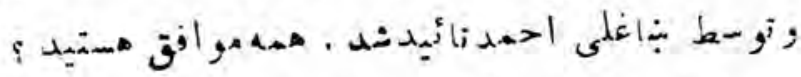

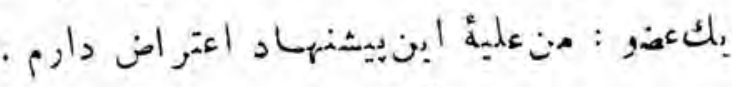
.

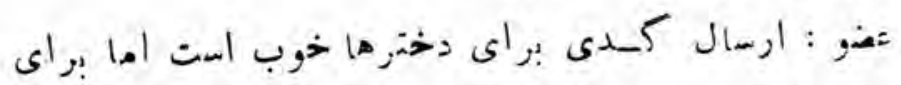

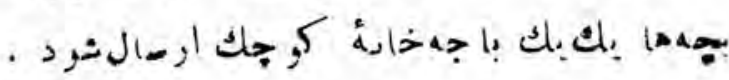

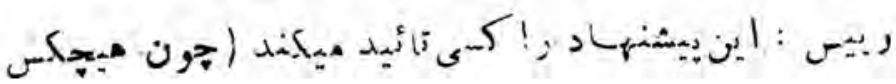


(v) :

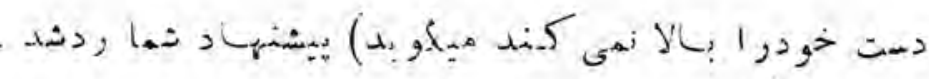

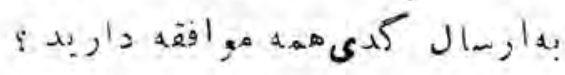

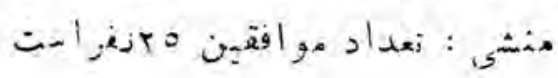

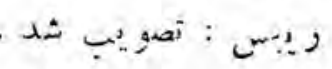

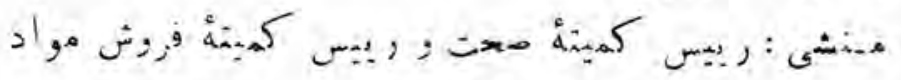

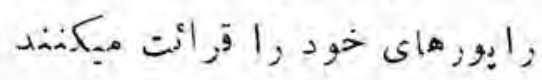

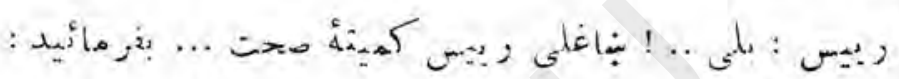

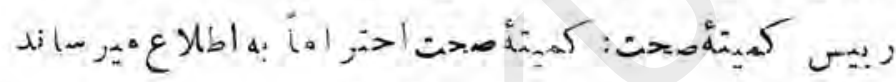

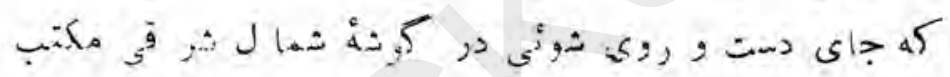

. A

جاض

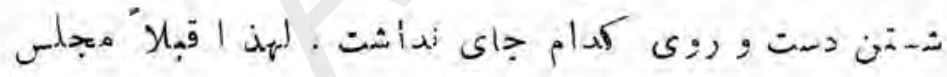

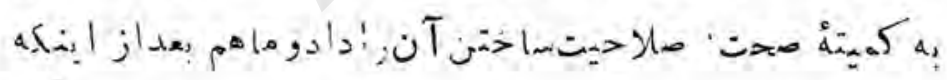

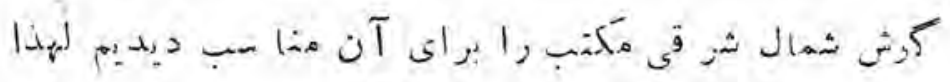

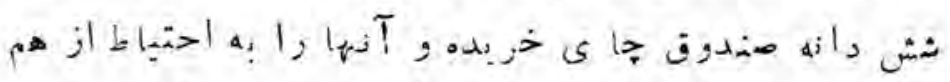

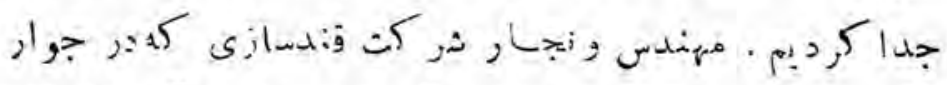

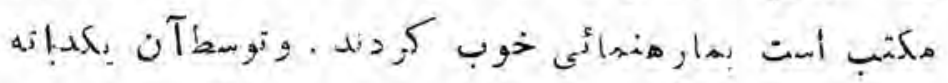

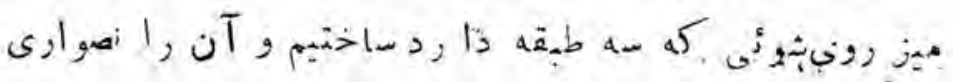


(vr)

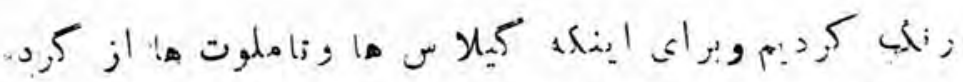

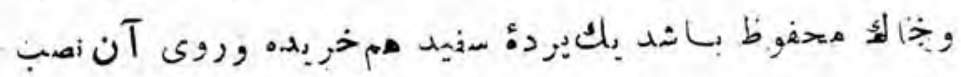

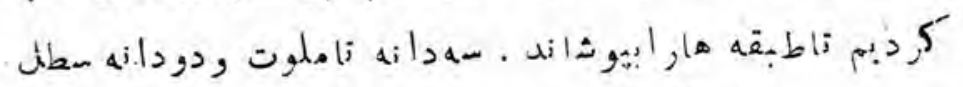

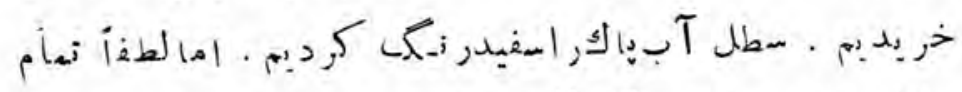

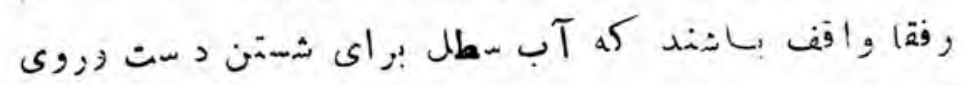

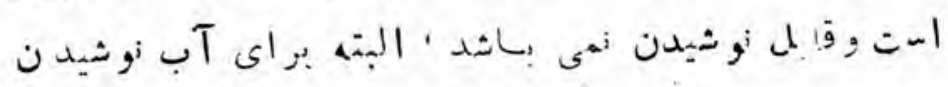

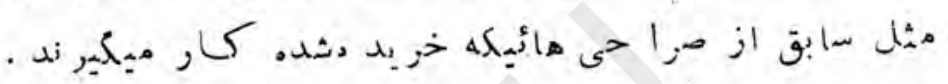

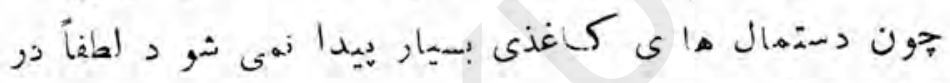

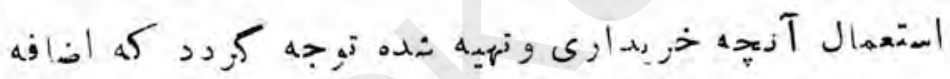

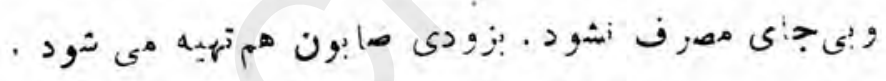

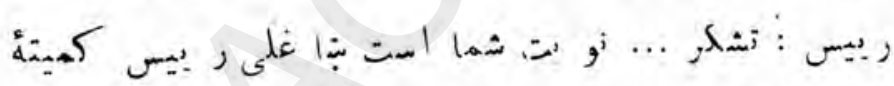

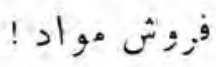

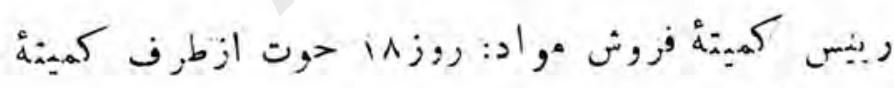

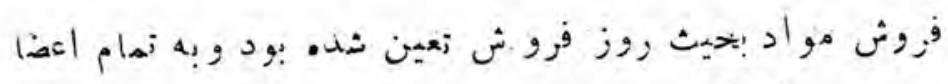

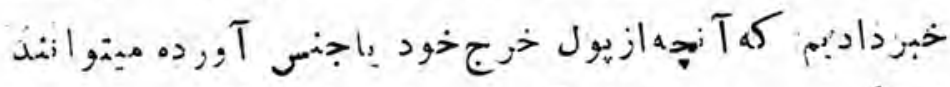

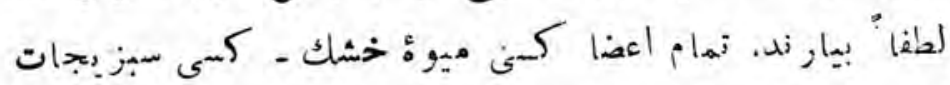

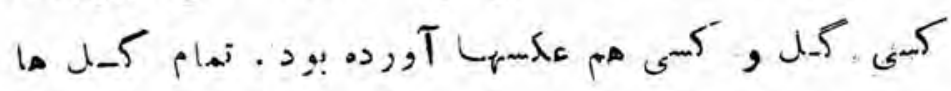

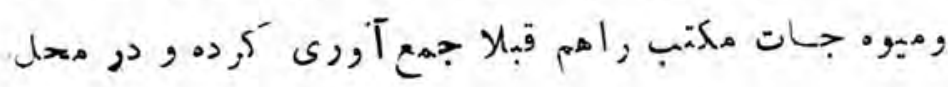


$(\mathrm{V} r)$

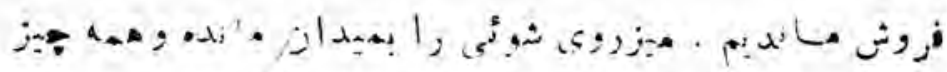

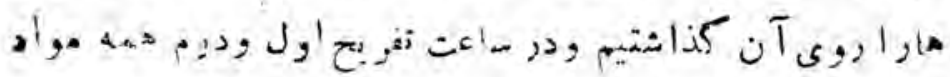

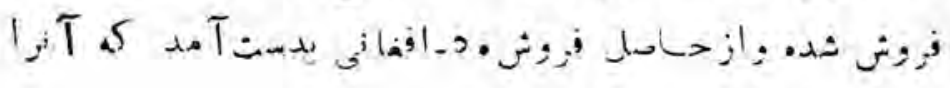

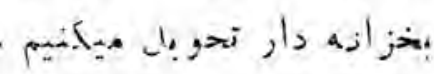

؛

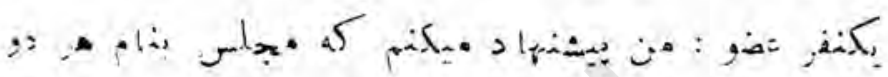

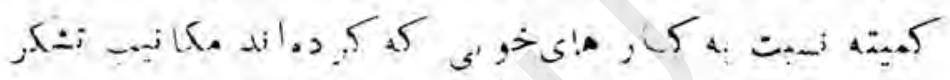

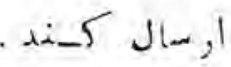

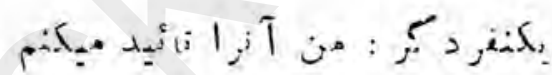

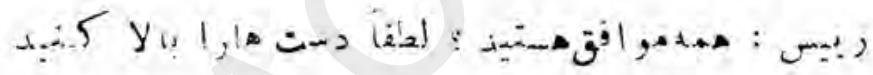

هis :

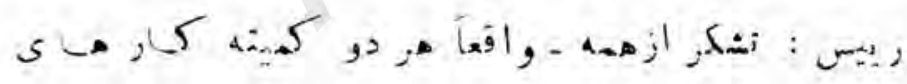

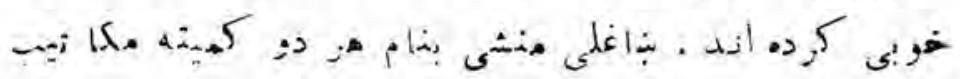

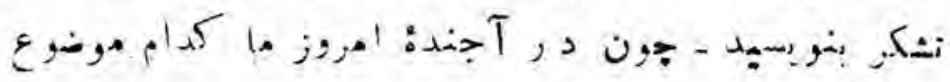

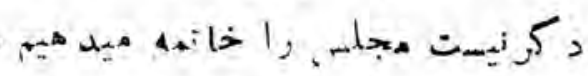

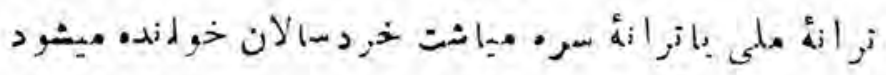

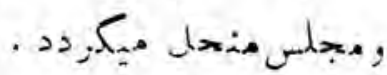


$(v \varepsilon)$

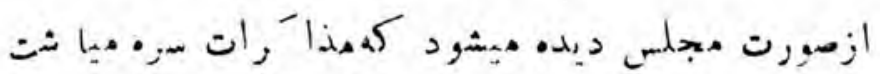

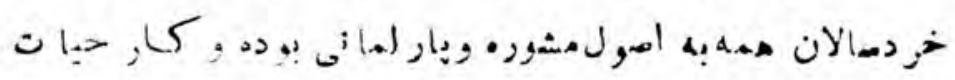

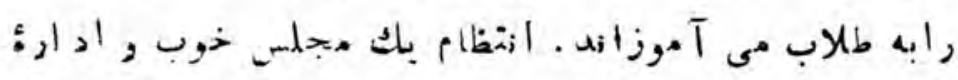

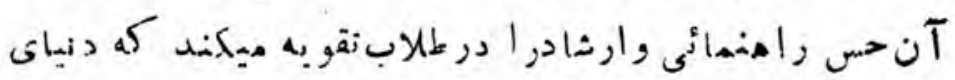

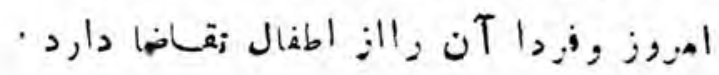

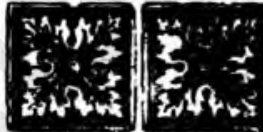


(vo)

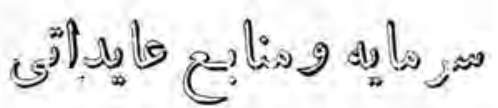
سر مميـاشت خر دسالان

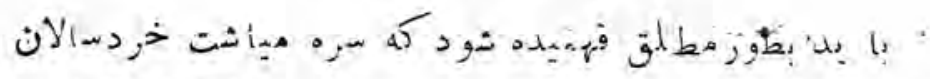

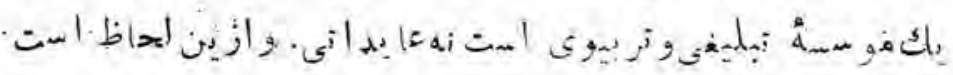

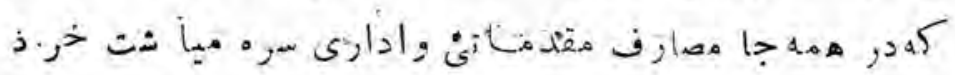

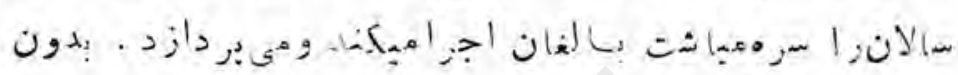

.

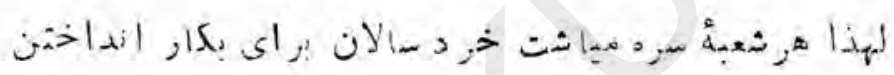

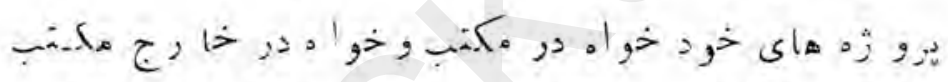

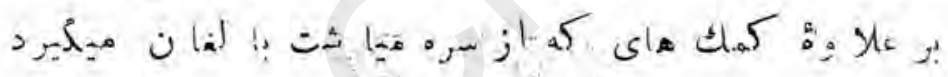

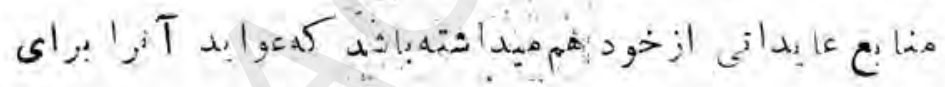

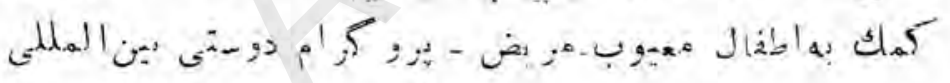

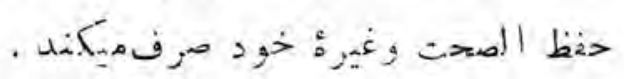

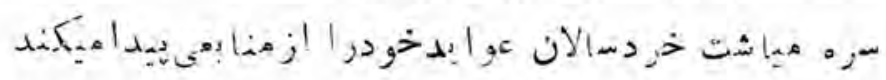

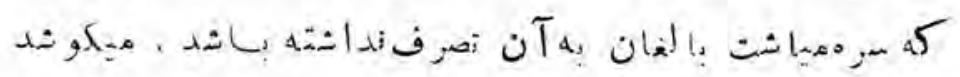

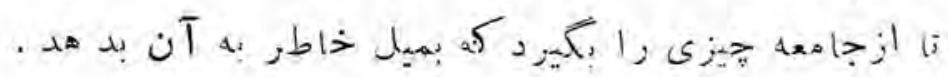

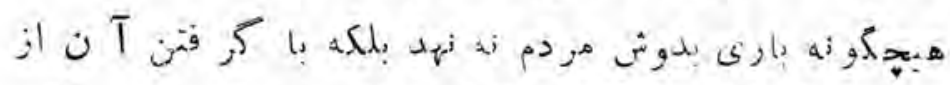

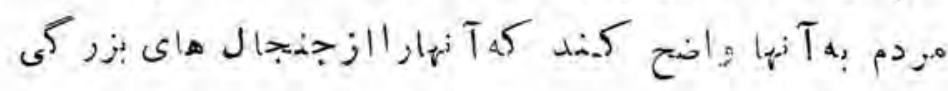


(vง)

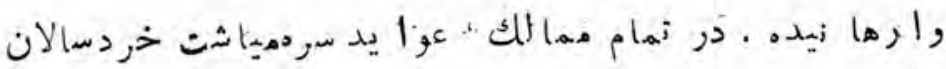

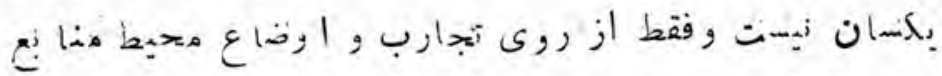

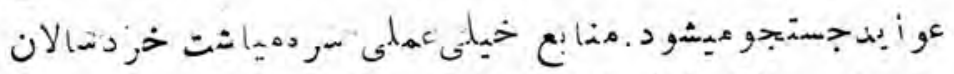

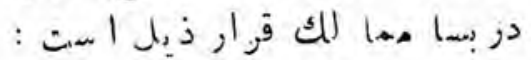

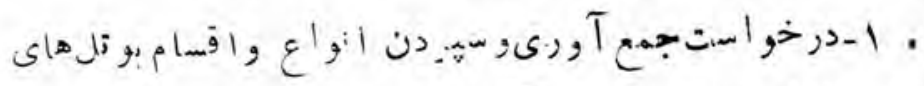

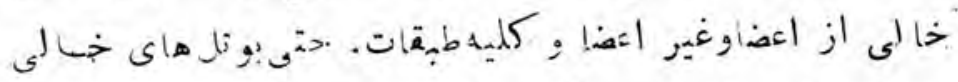

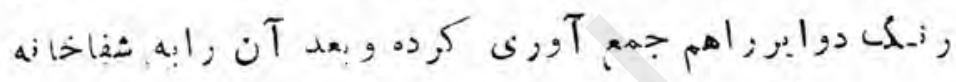

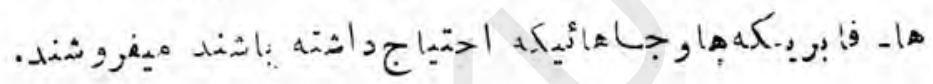
r-

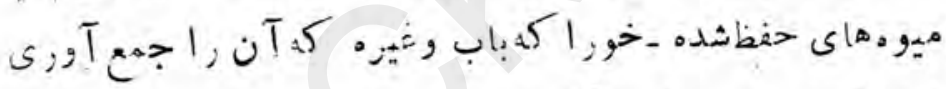

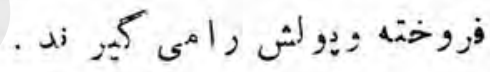
r-

ك. .

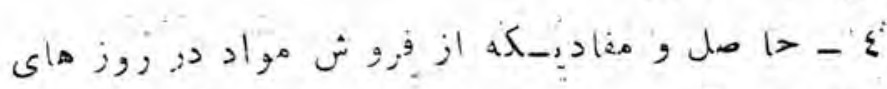

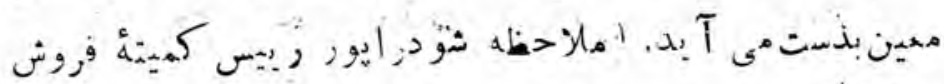
( )

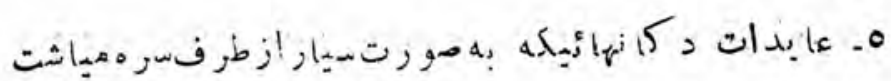
جوان 
(vv)

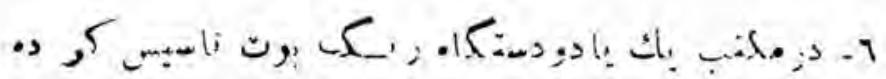

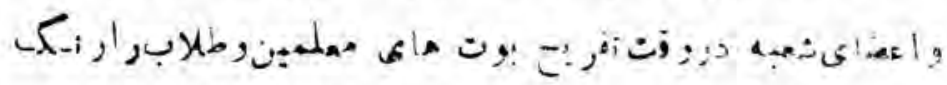

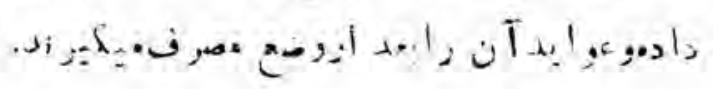

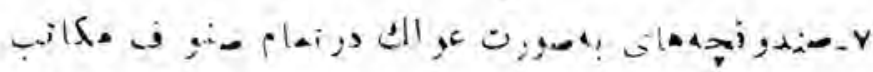

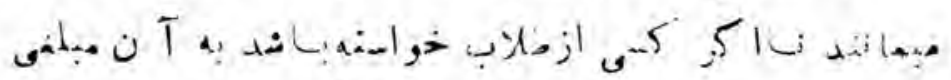

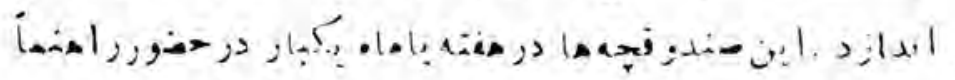

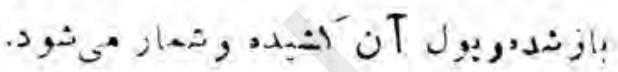

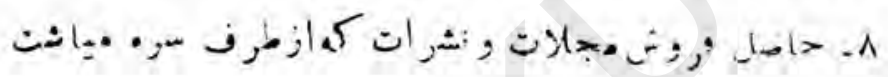

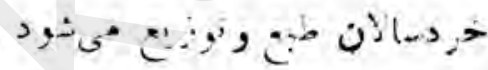

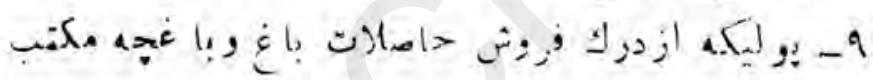

ar.

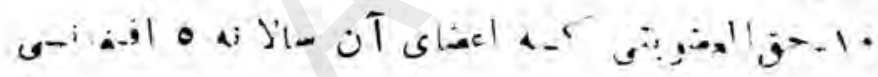

. Ai jos

-

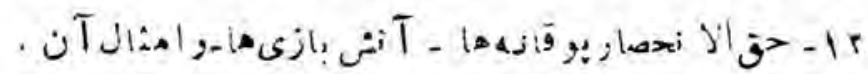

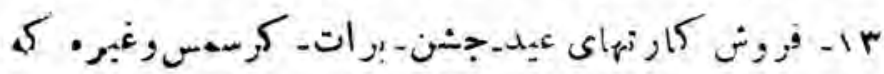

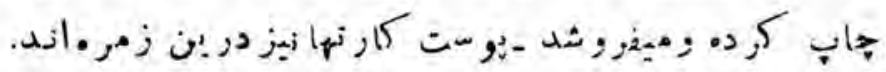

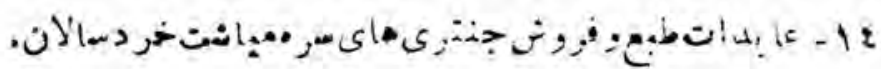




\section{( $\vee \wedge)$}

مأ - 10

$$
\text { . }
$$

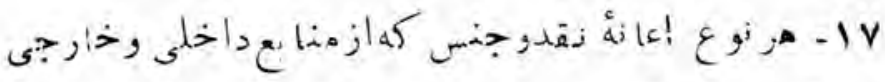

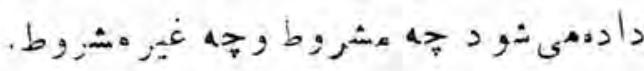

$$
\text { 11 }
$$

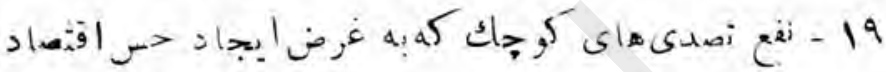

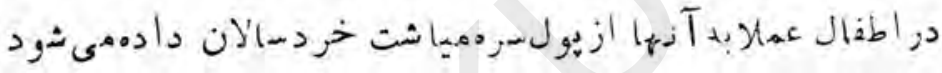

$$
\text { أ }
$$

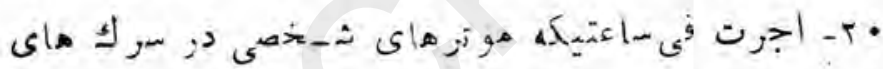

$$
\text { C. }
$$

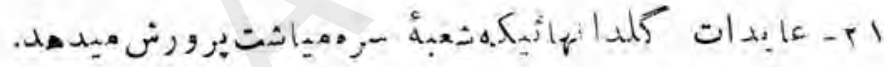

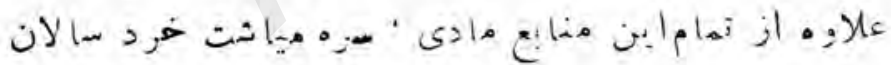

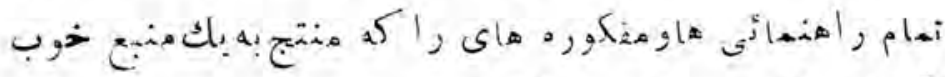

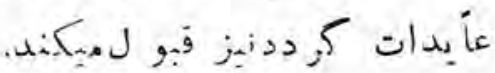


(va)

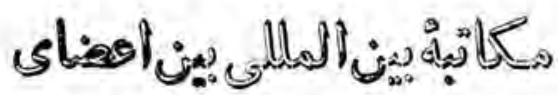

سره مياثت خر د سالان

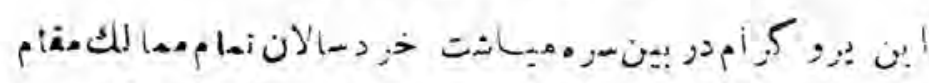

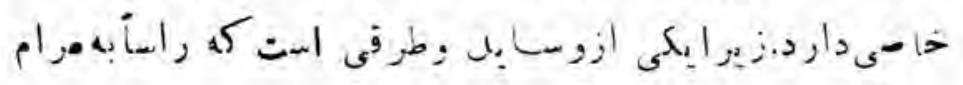

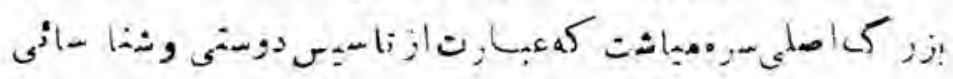

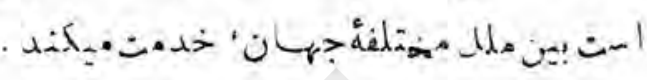

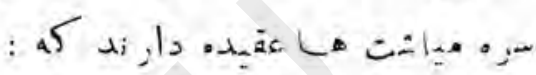

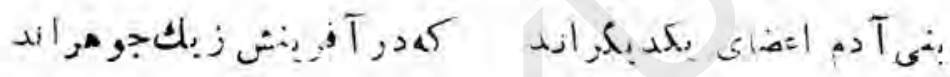

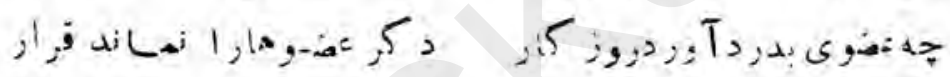

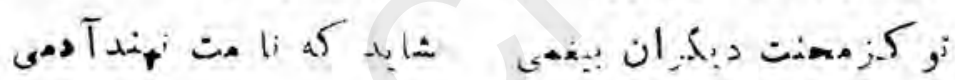

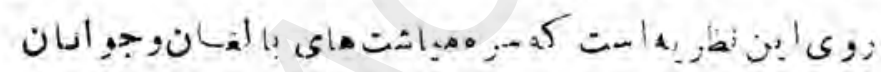

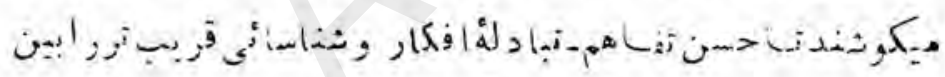

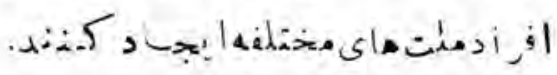

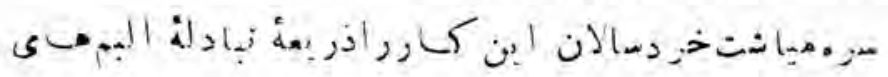

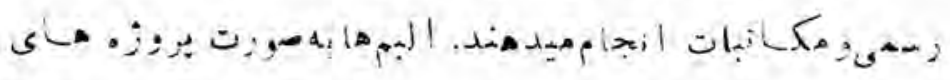

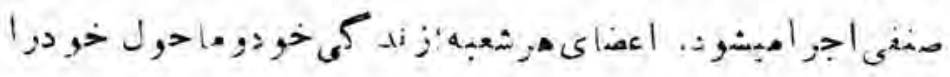

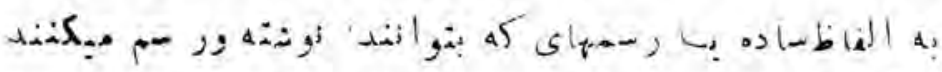

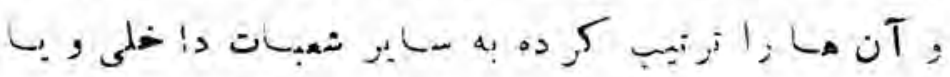




$$
(\wedge \cdot)
$$

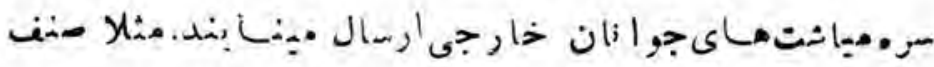

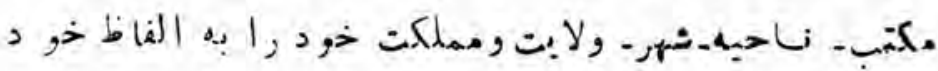

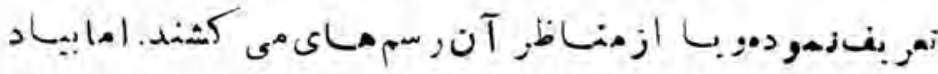

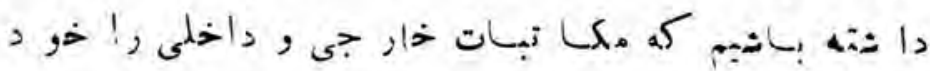

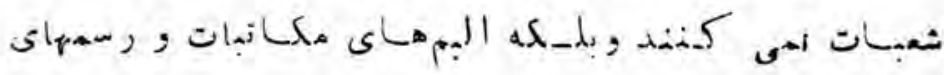

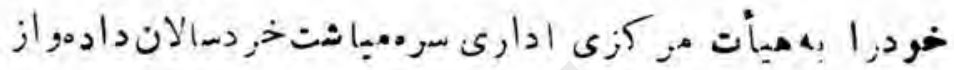

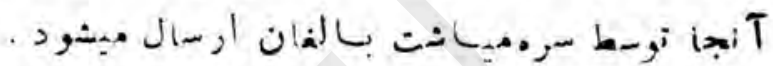
هاتبه جطور آغازهيشود:

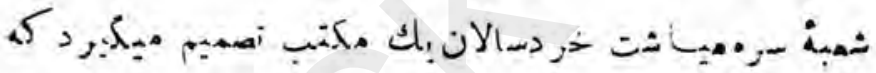

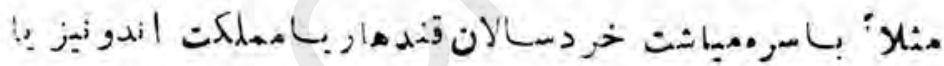

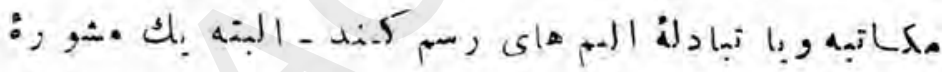

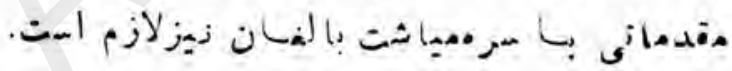

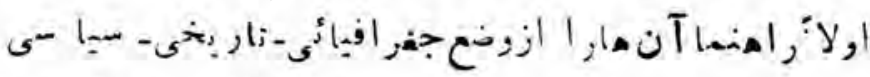

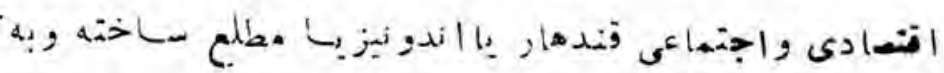

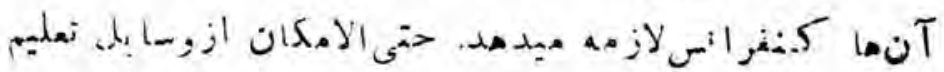

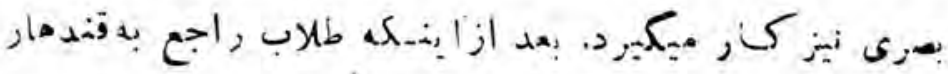

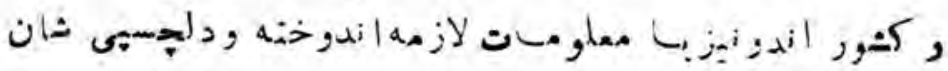

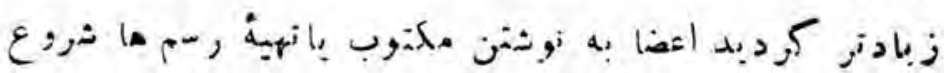


$(\wedge$,

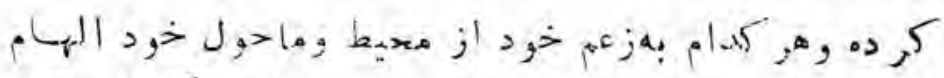

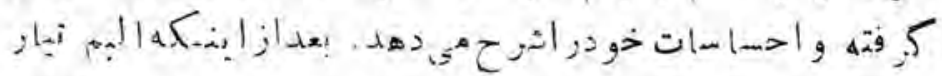

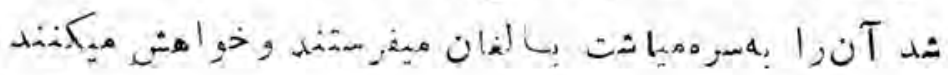

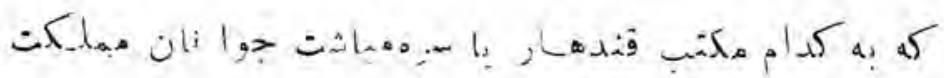

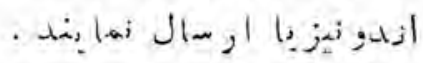

جواب حهوقت خو المد رسيد؟

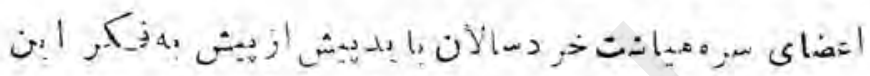

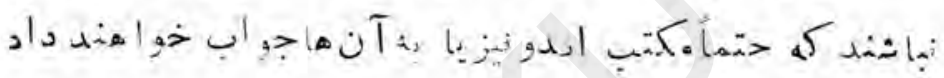

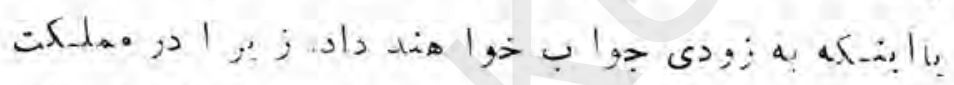

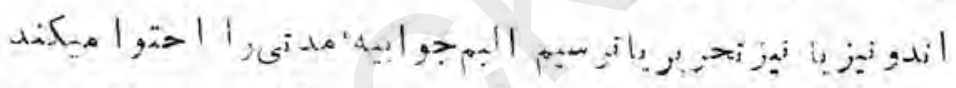

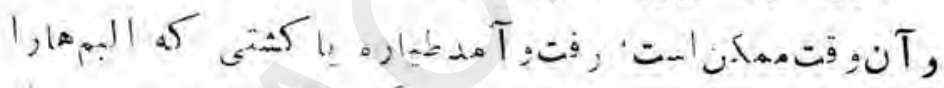

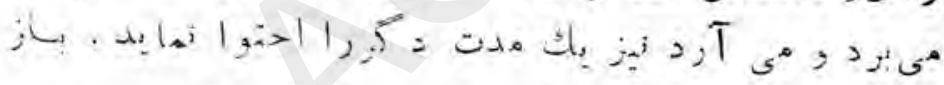
وقتيكه

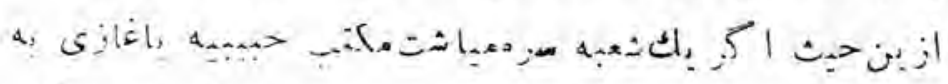

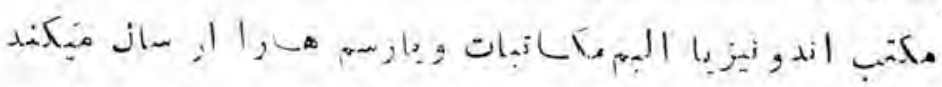

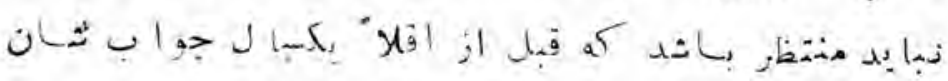

in

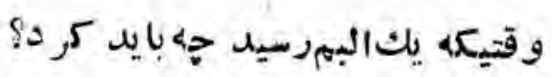

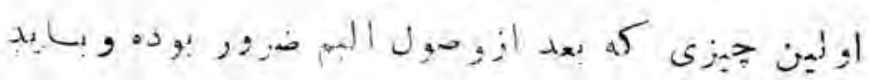


$(\Lambda T)$

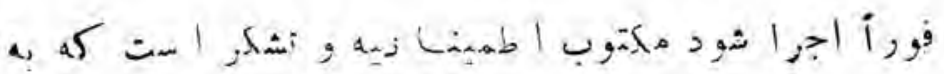

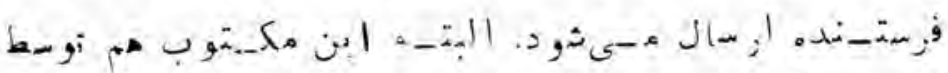
سره مياشت ill بـ .

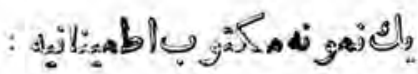

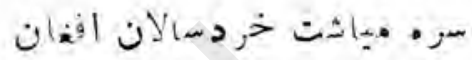

تجات

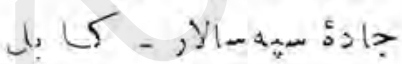

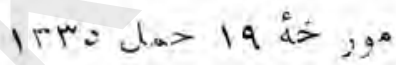

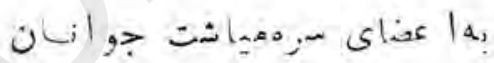

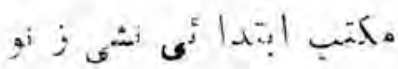

IT, ج

$-0 \log 20$

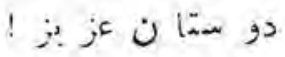

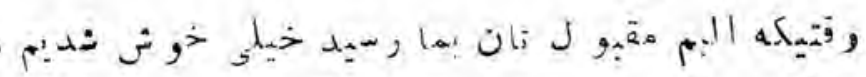

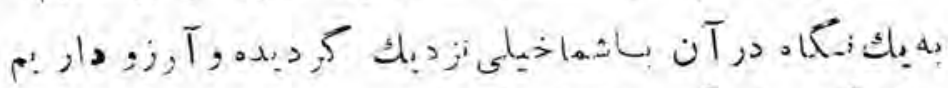

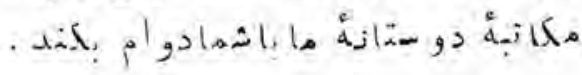

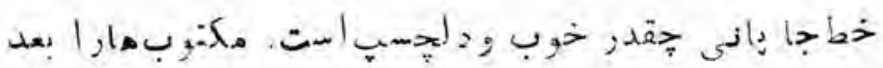


$(\wedge r)$

از

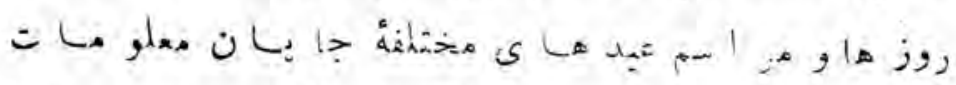

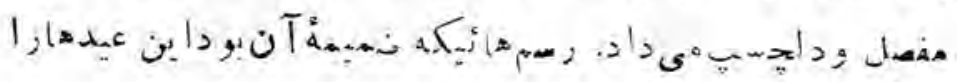

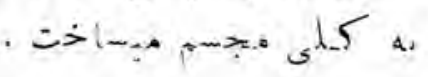

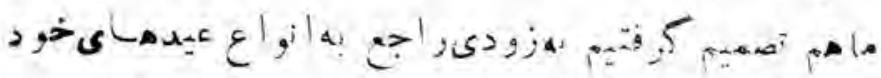

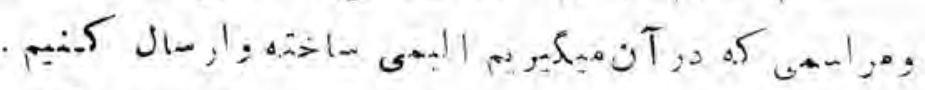

(

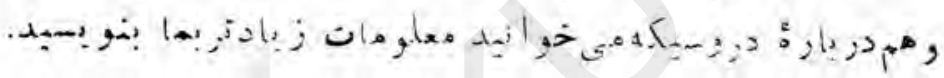

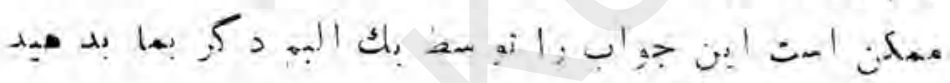

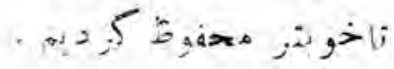

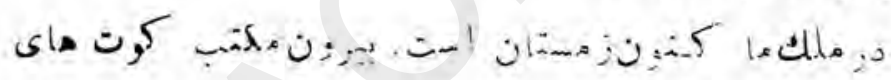

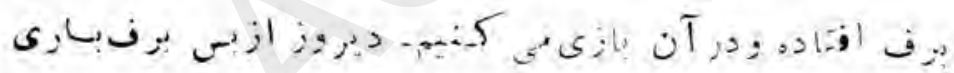

زيا20

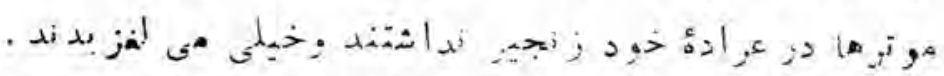

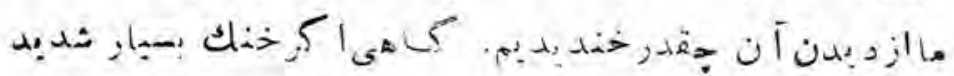

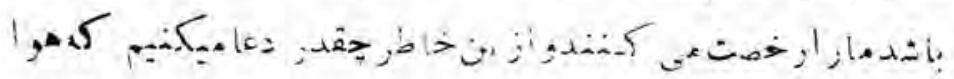

- خوب

كم

a 
$(\wedge \varepsilon)$

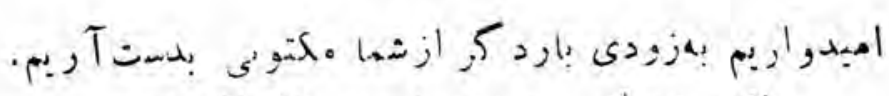

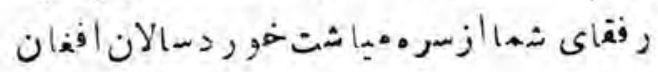

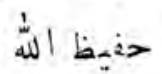

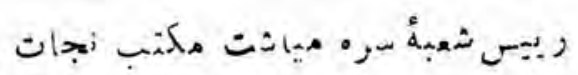

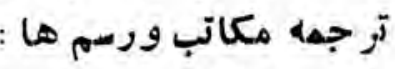

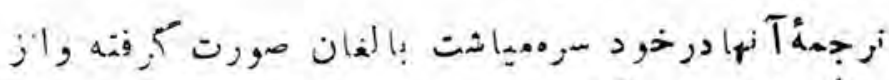

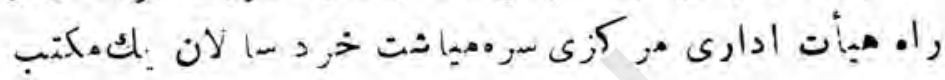

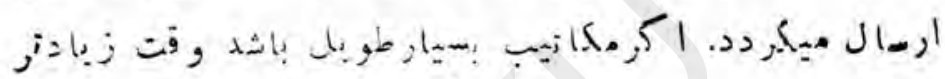

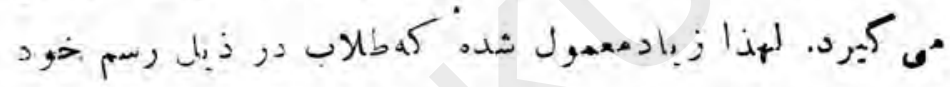

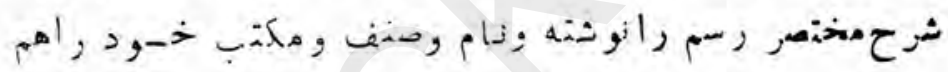

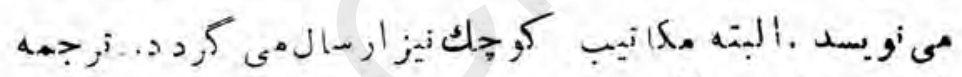

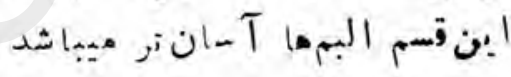

بلان البمراحطور ميىساز زند

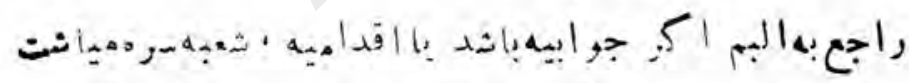

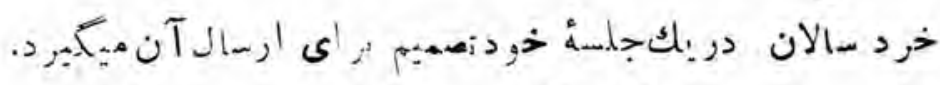

.

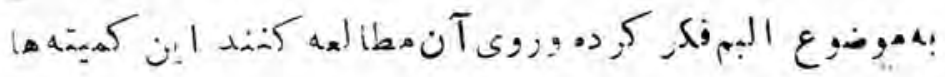

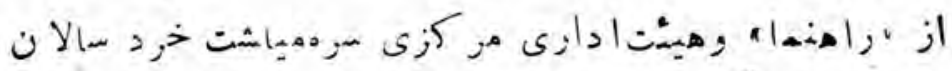

زيزمثور . ميكير ده ده 
(10)

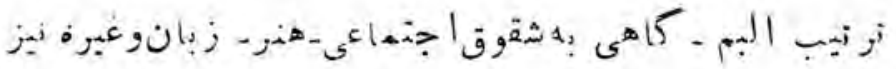

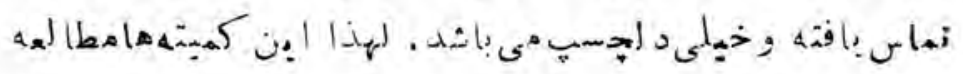

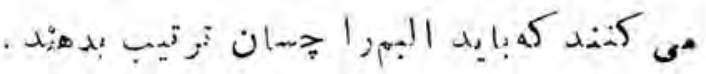

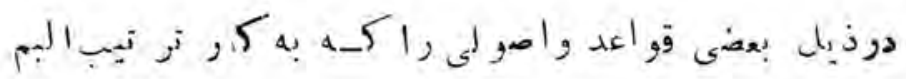

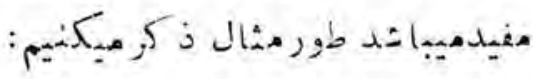

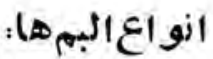

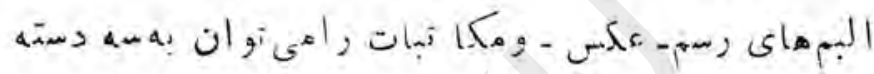
is

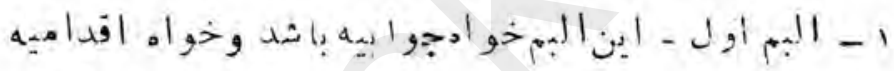

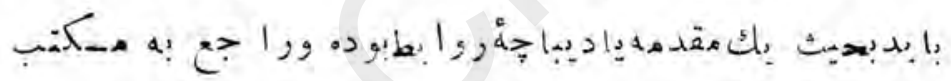
ومهلمتاك بك تصوير عهوبى بدهد.

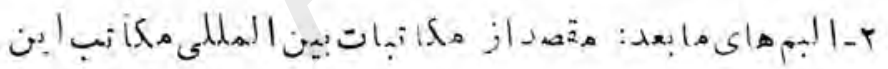

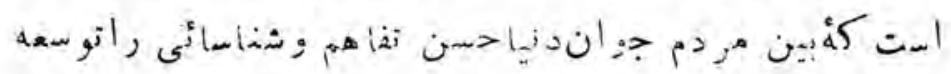

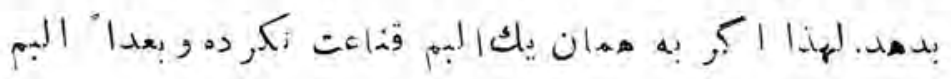

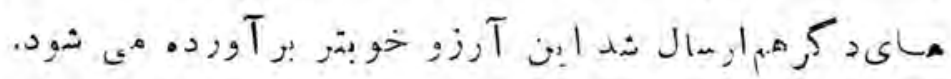

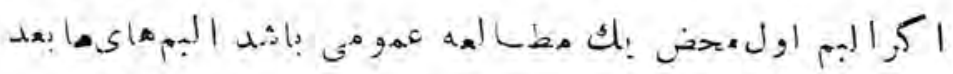

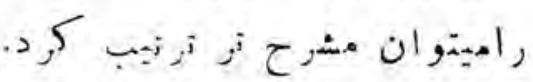

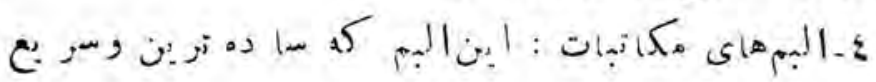


(^r)

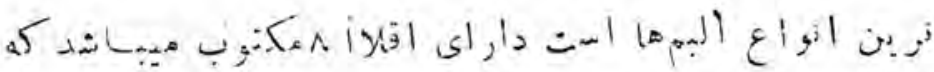

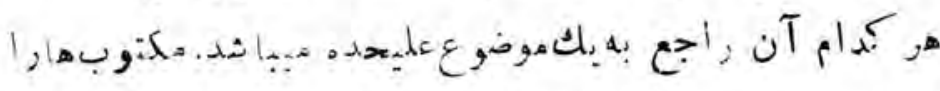

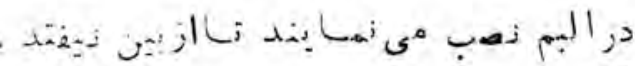

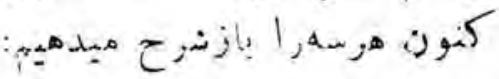

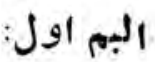

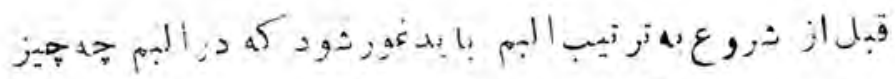

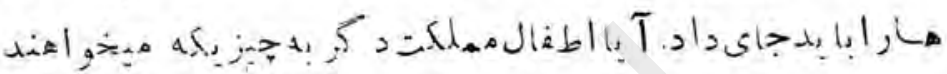

Lu, $1=0$, $1=0$

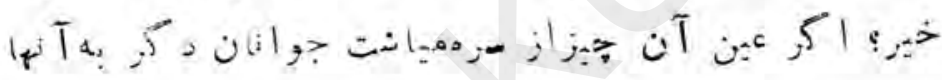

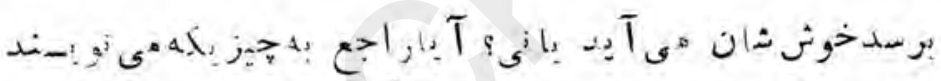

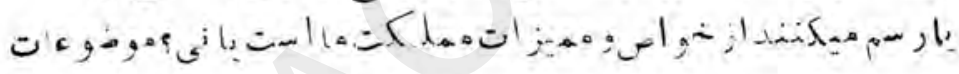

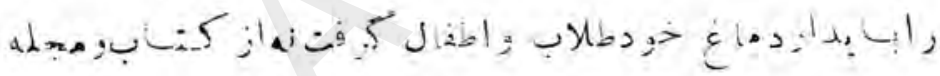

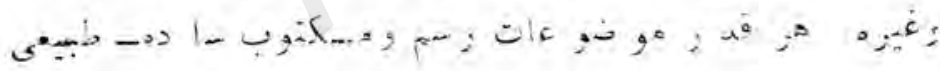

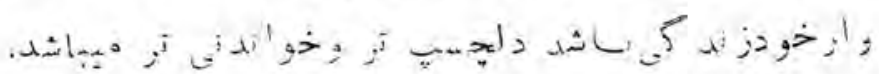

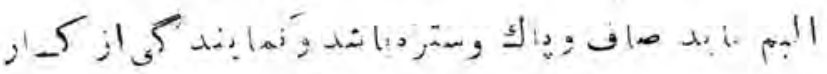

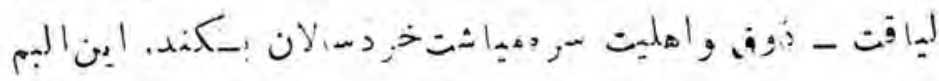

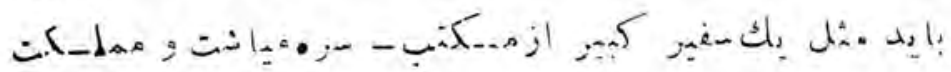

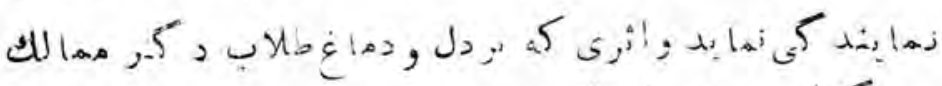

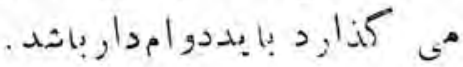


(^v)

هر البمبإيددار ائين جيز هاباشد:

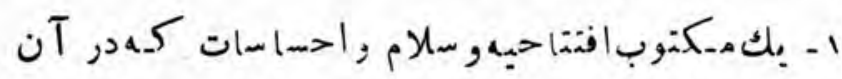

تمام طلاب بك صنف (ك.5هضو سرهمياشت خردسالان با شند)

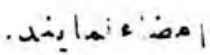

r- بـك ابور ك. كو جك حاوى از نش.كيلات سرمهيا شت

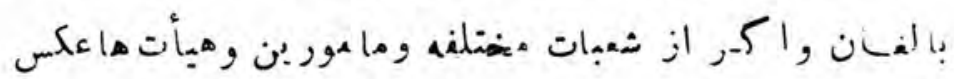

كان

إس

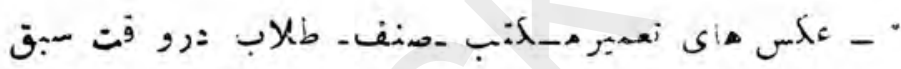

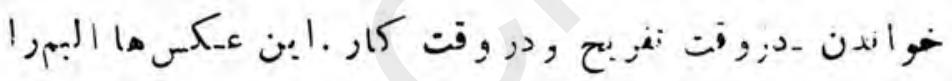

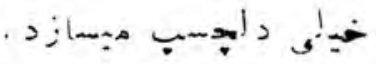

موضو عانيكهدرالبم هى توانتيد كرد:

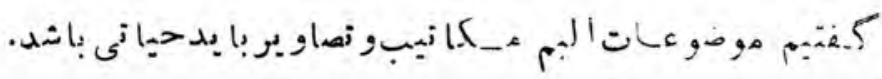

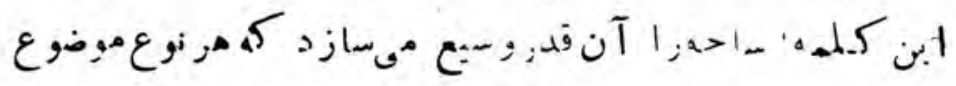

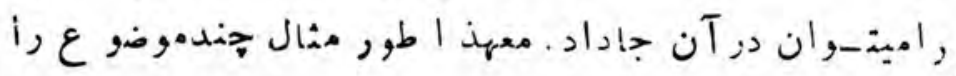

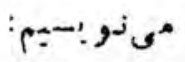

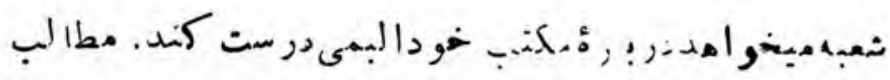

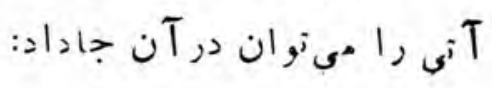


(^^)

"مكتبماه

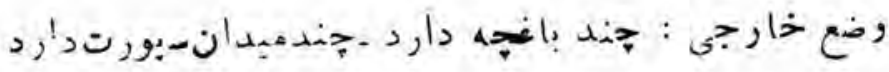

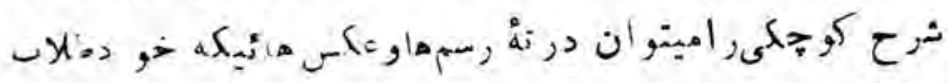

هـيكير ند نونت.

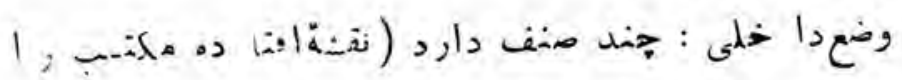

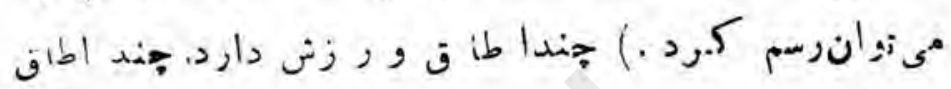

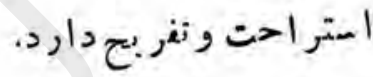

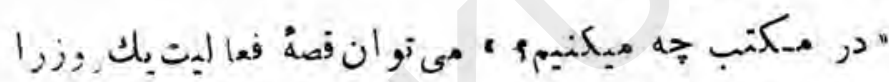

;

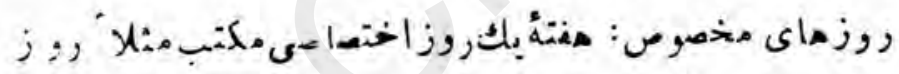

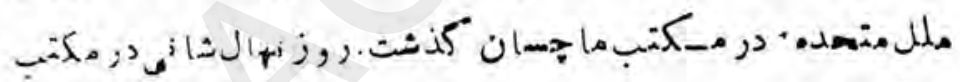

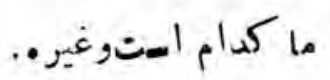

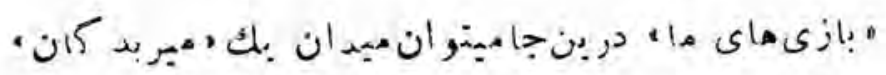

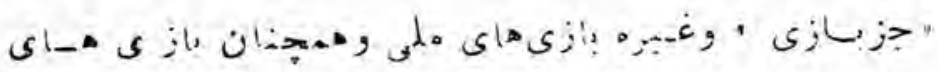

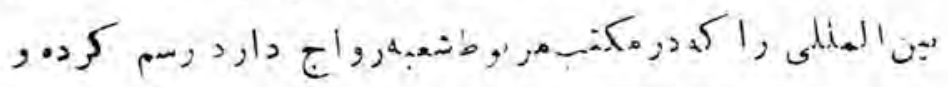

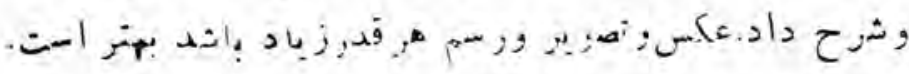

"جامado"

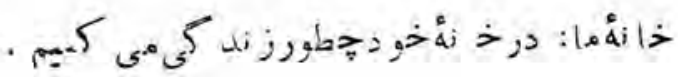


$(\wedge q)$

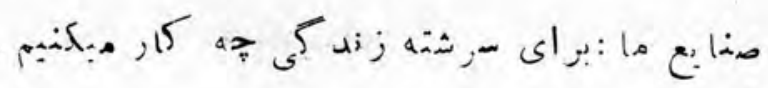
ن.

ورز

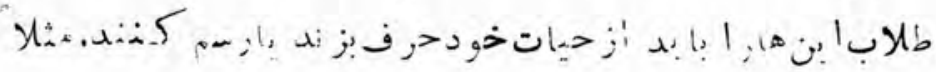

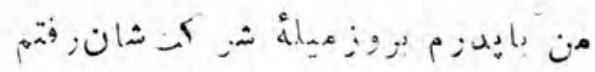

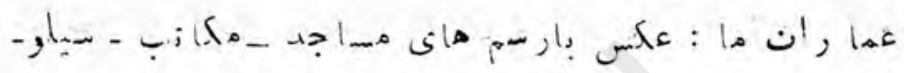

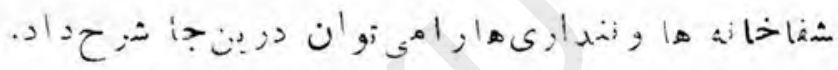
"ولايتهاه

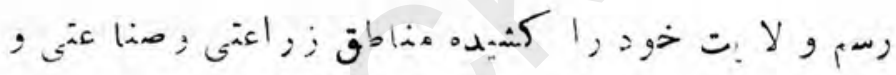

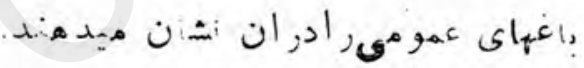

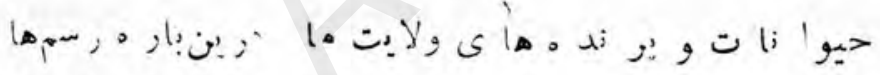

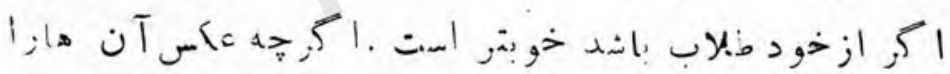

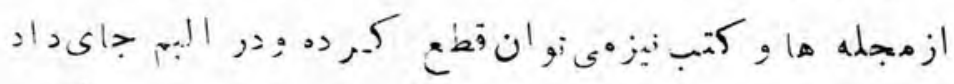

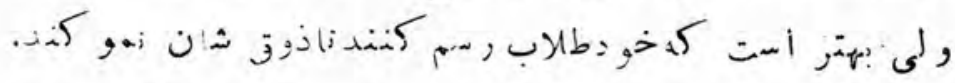

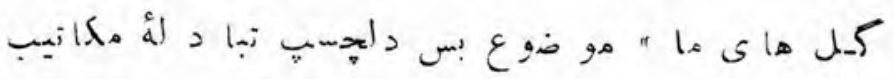

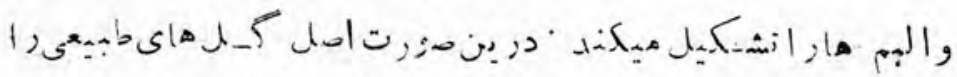

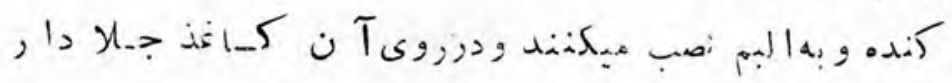

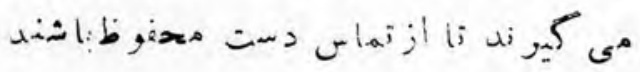


(a.)

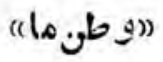

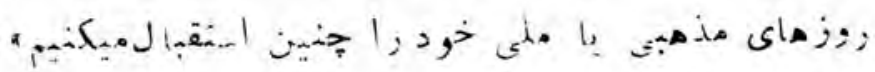

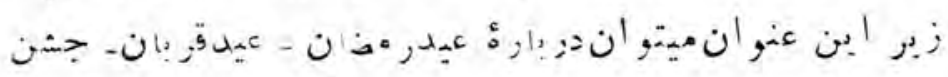

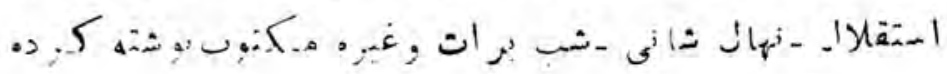

$0+20,1$.

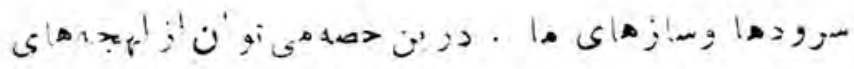

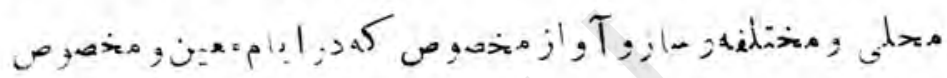

'

$.0,8$,

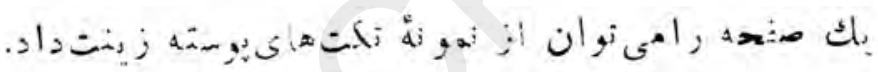

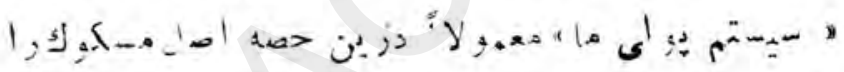

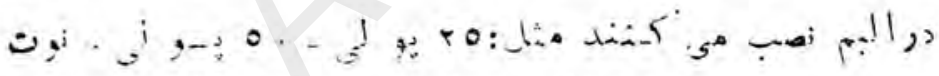

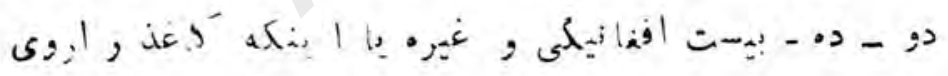

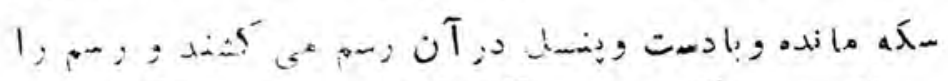

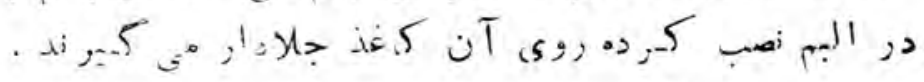

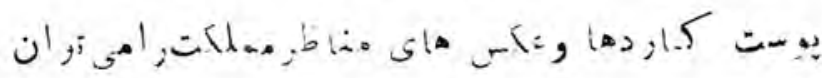

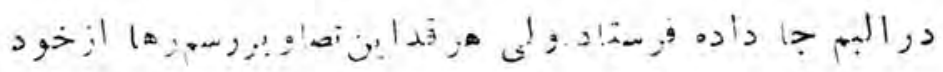

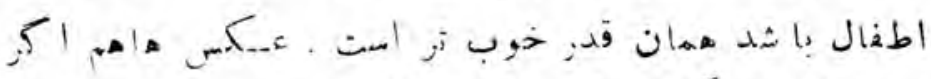

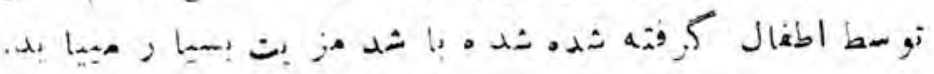


(91)

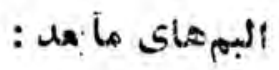

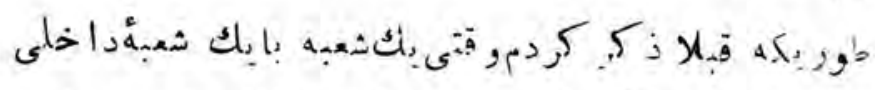
:

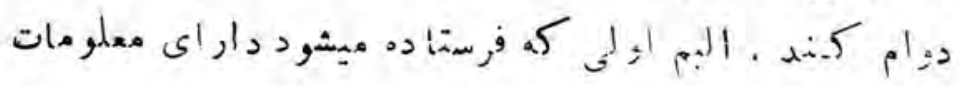

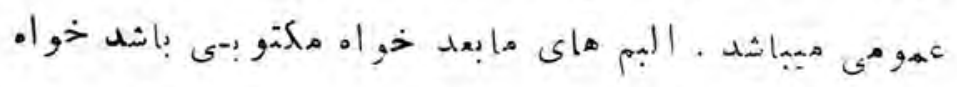

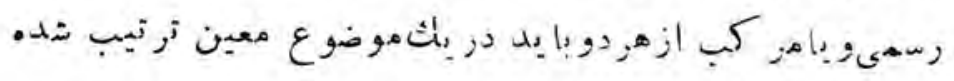

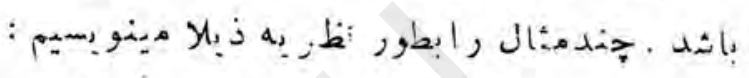

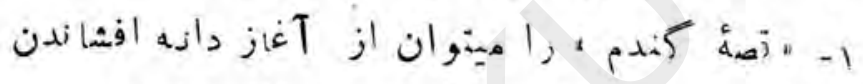

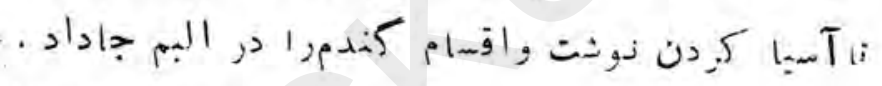

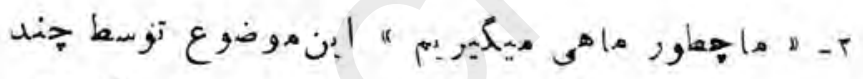

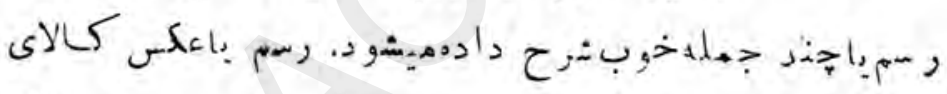

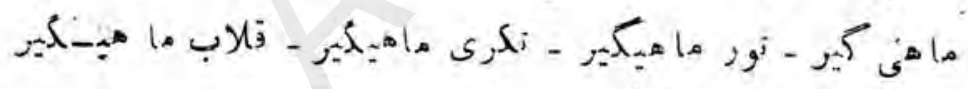

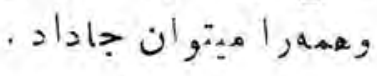

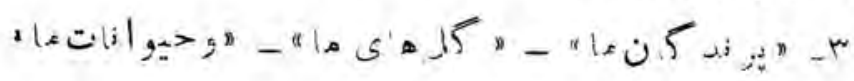

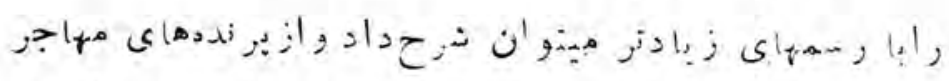

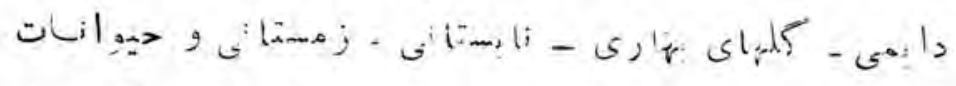

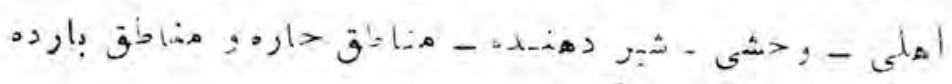

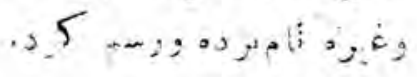

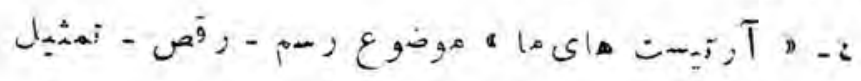


$(9+)$

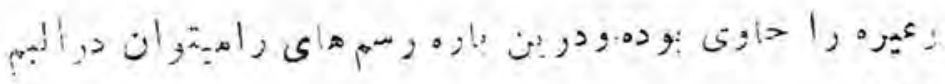

جاداد.

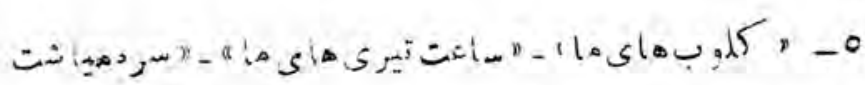

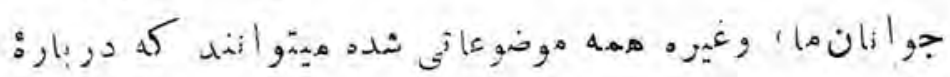

آن البما ميثوان سان ساخت

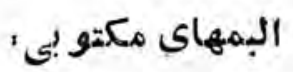

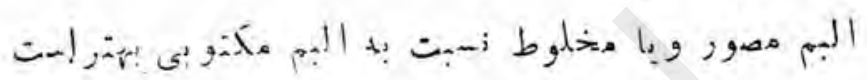

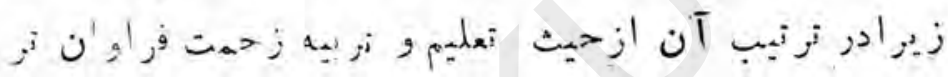

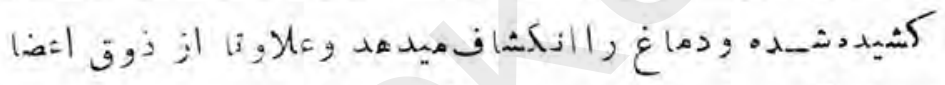

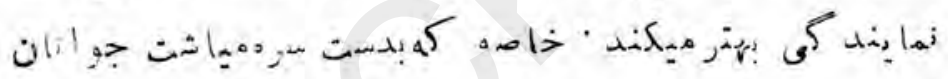

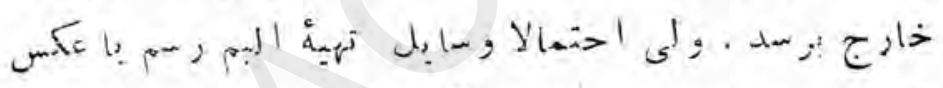

.

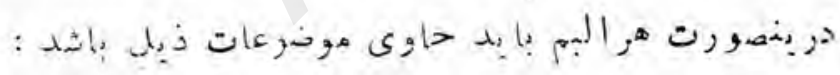

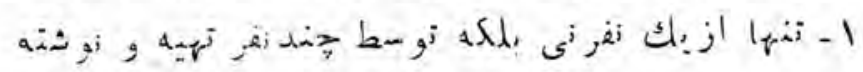

شد. با ثد .

和

ب

داتخه باثند. 
$(a r)$

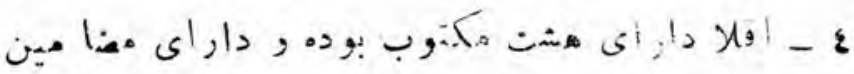

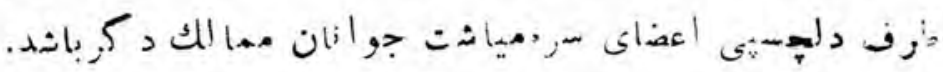

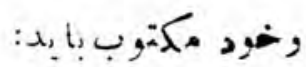

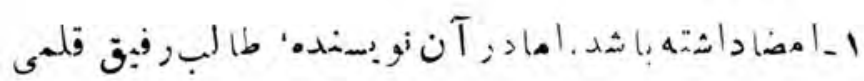

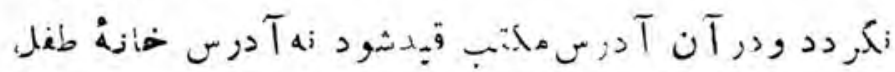

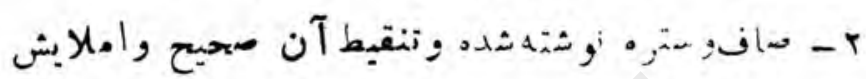

ورستبان

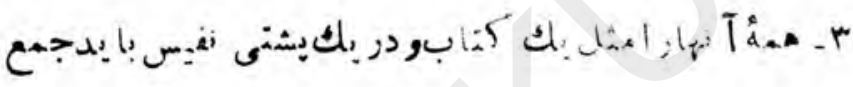

...

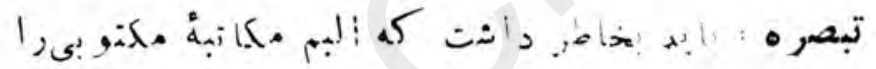

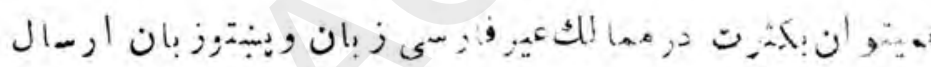

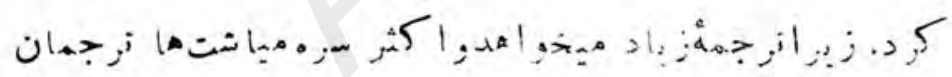

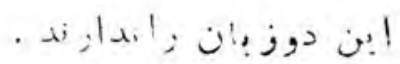

مكاتيب سلام ودوستى

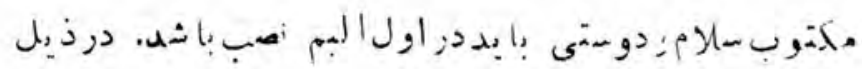

:

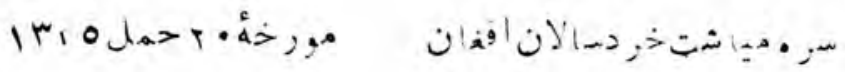

j:aladl, 12 
$(9 z)$

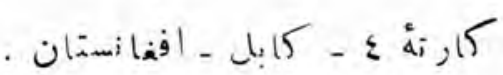

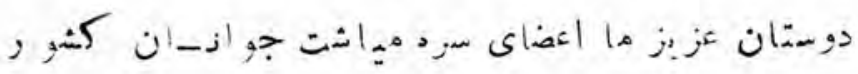

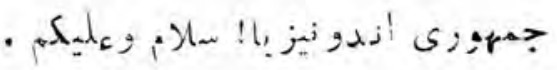

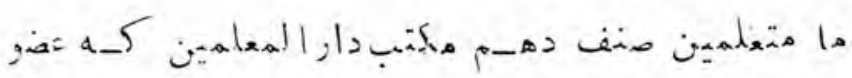

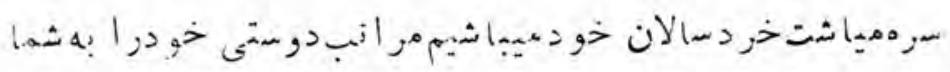

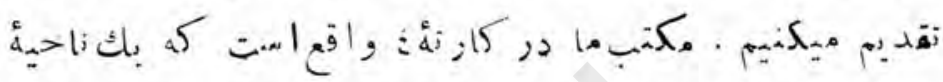

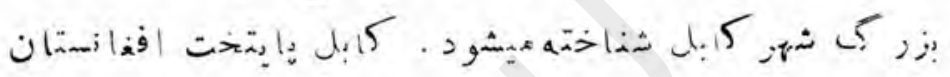

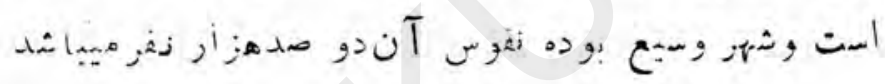

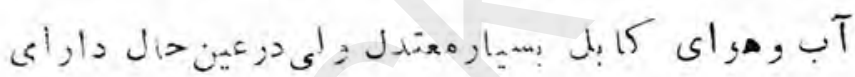

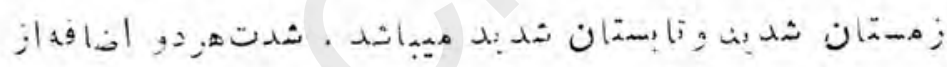

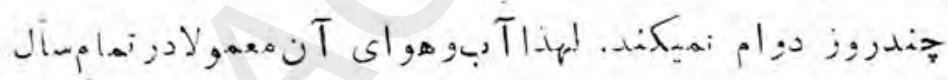

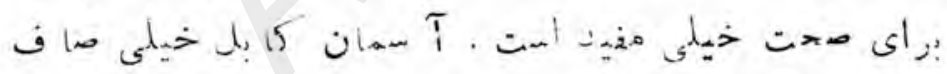

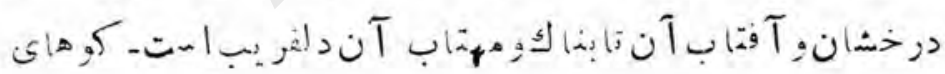

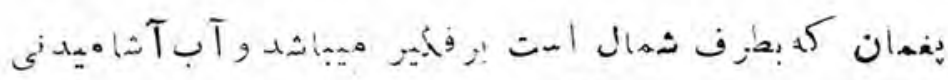

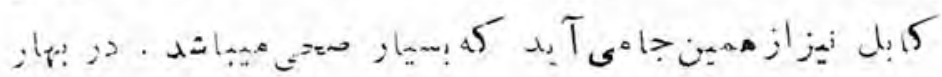

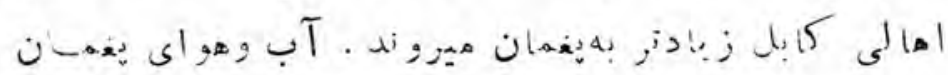

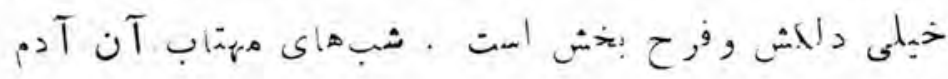

2 2 2 
$(40)$

.

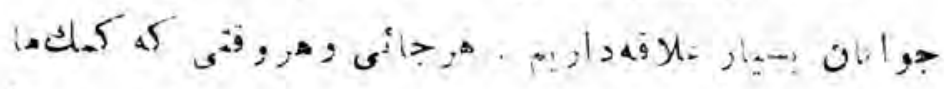

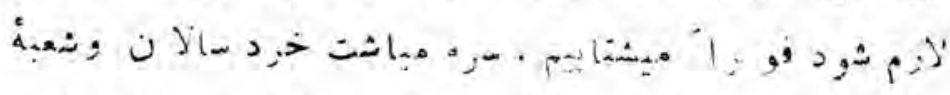

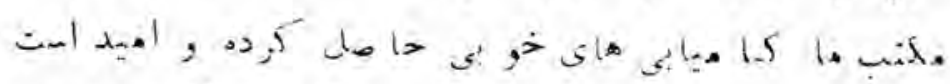
ا

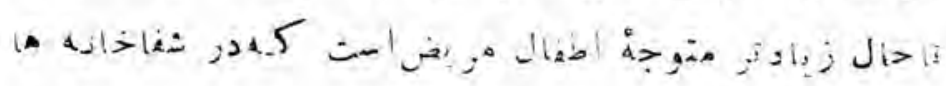

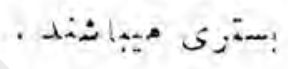

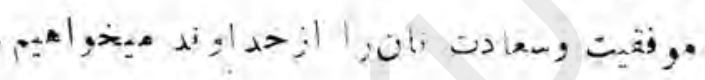

ن ن ن ving

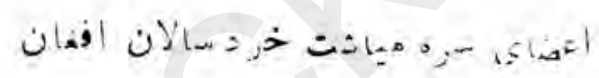

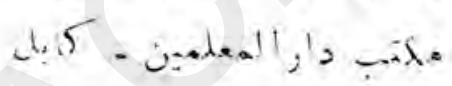

-

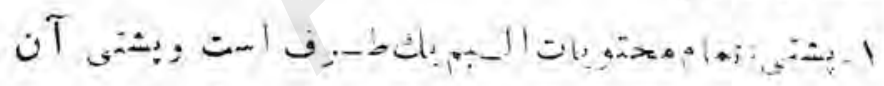

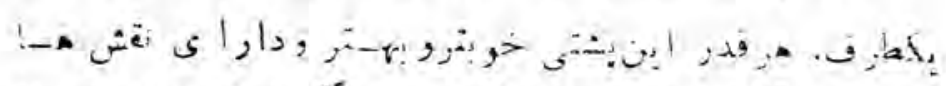

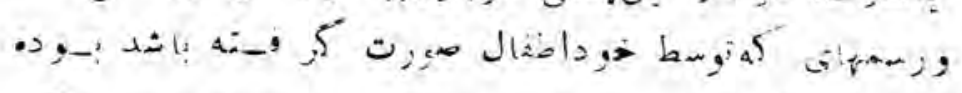

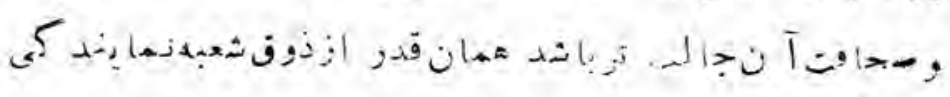

.+5 s.

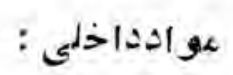

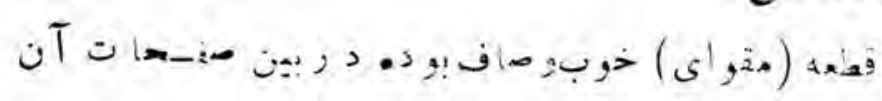


$(97)$

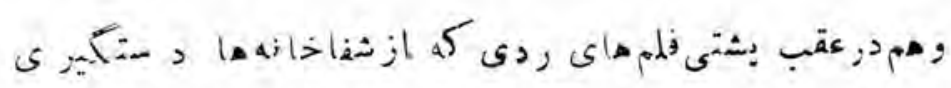

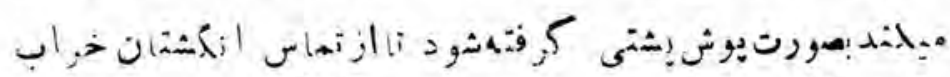

أك. الك.

زتوش:

1

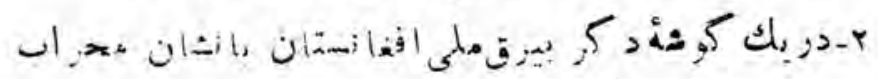

رنمبررسمشود.

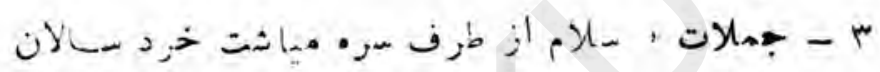

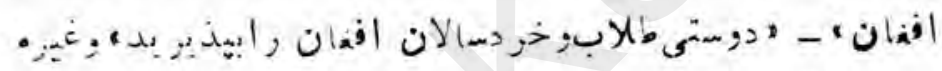

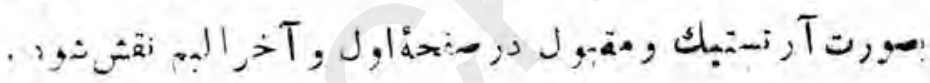

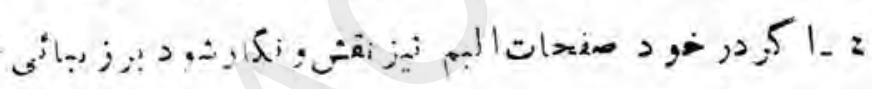

آن مى افزايد.

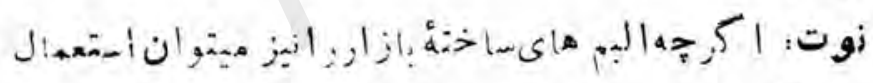
ذصن

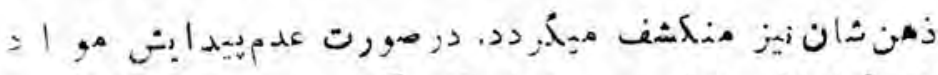

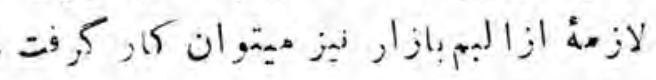

وزنو اندازه :

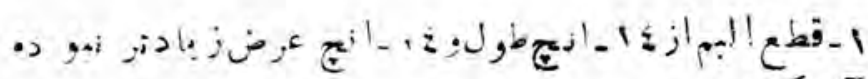

. 
$(9 v)$

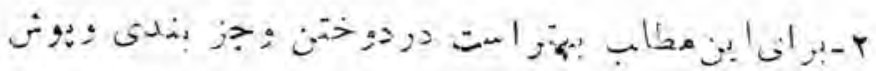

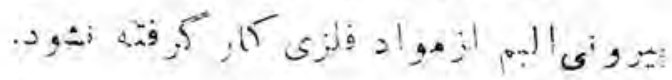

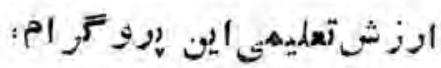

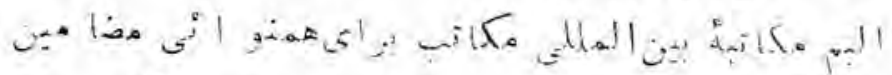

il

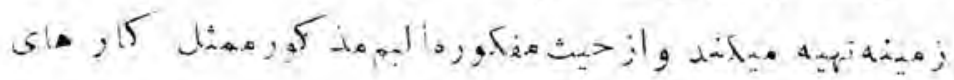

A

د,

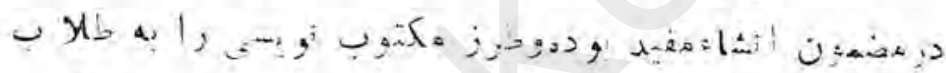

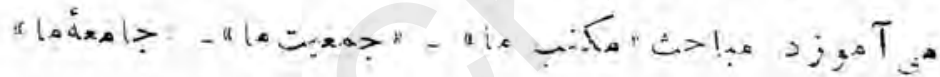

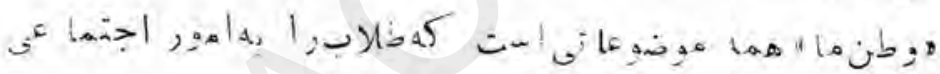

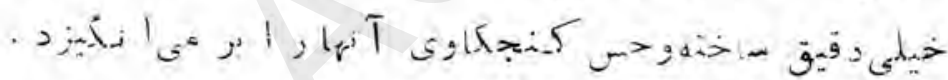

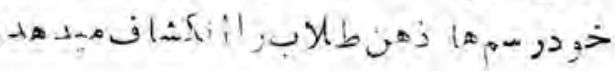

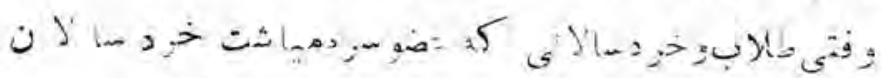

जز

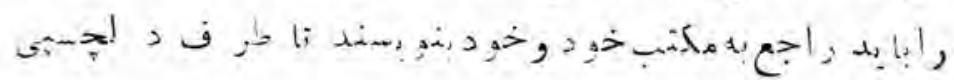

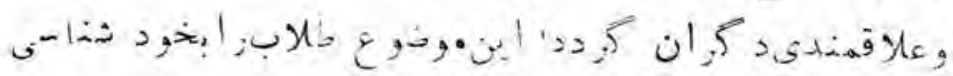

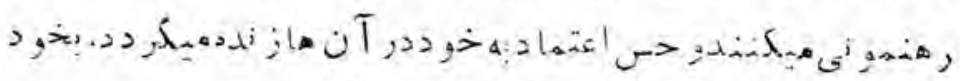

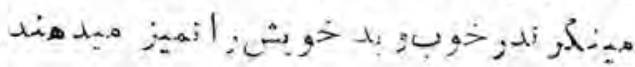


$(\cdot \wedge)$

هـ

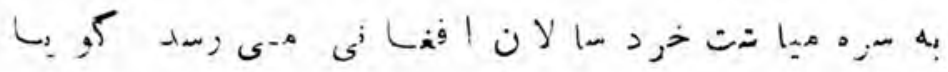

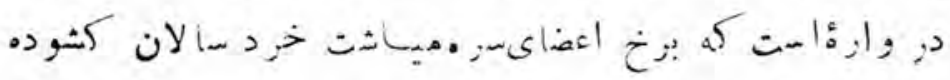

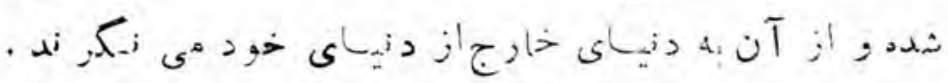

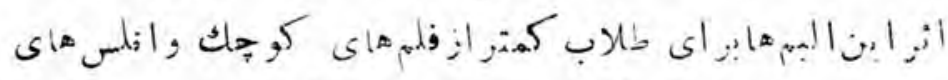

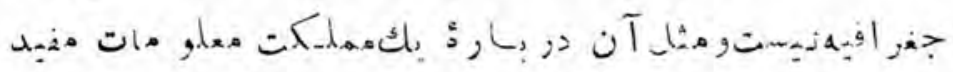
IA 4.0 C

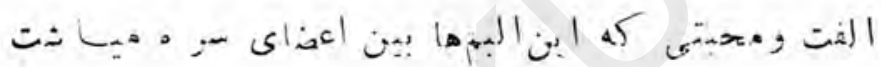

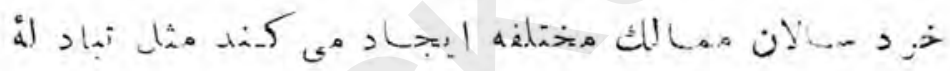
. $2,12,0$ i

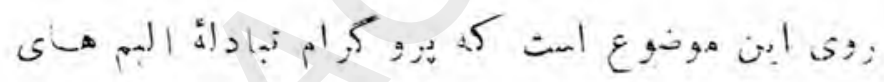

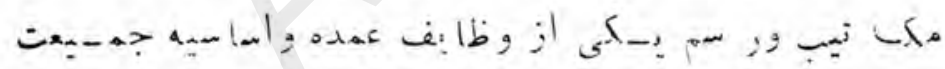

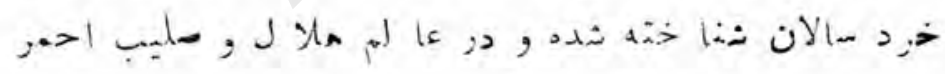

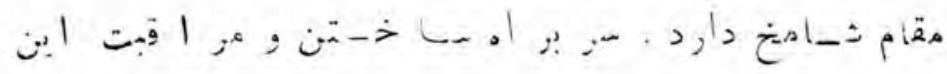

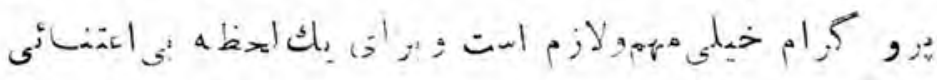

ماندي

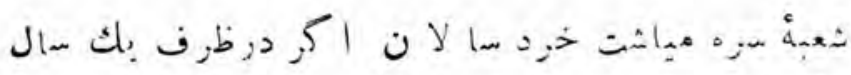

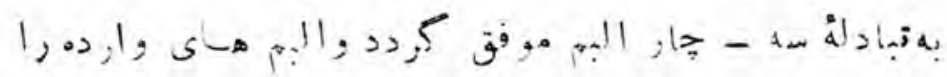


(99)

然

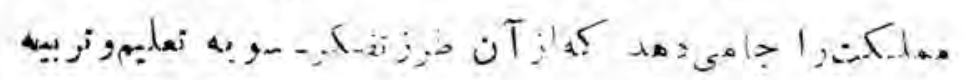

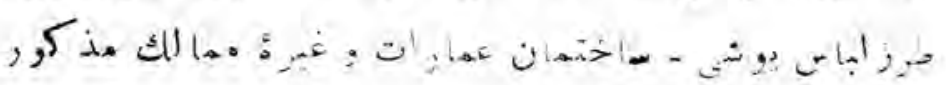

لدil 


$$
(1 \cdots)
$$

ك

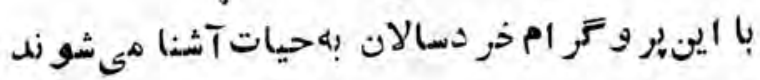

الجسب أر

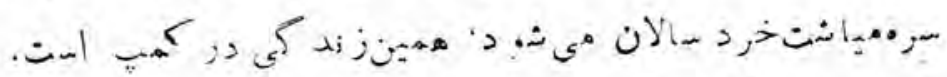

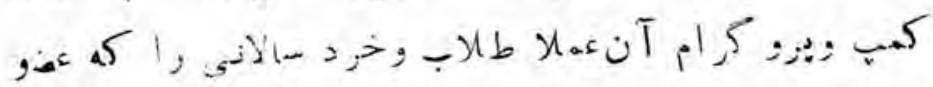

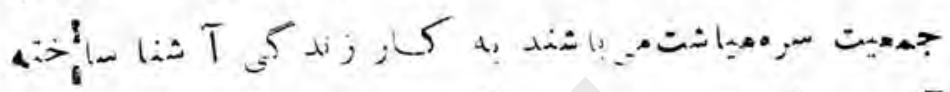

آ

مي

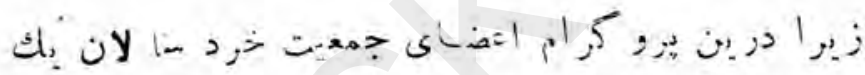

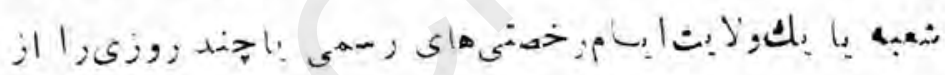

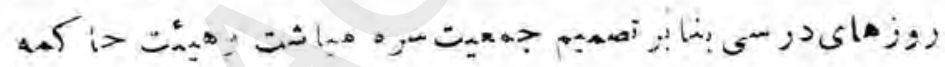

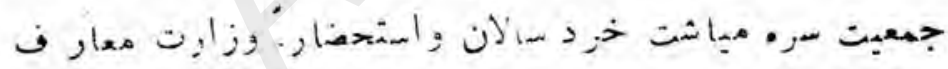

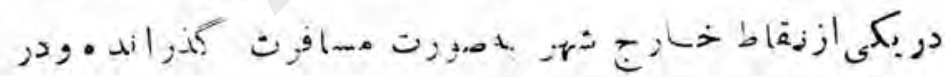

i. 1.5 .

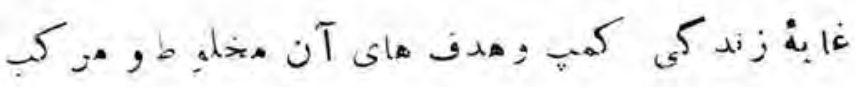

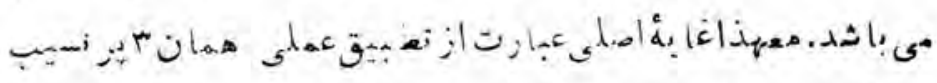

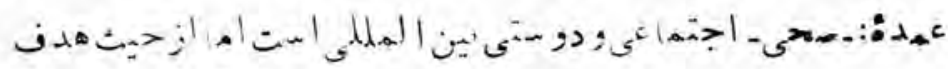

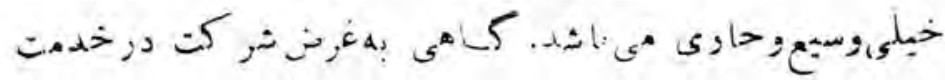


$(i \cdot 1)$

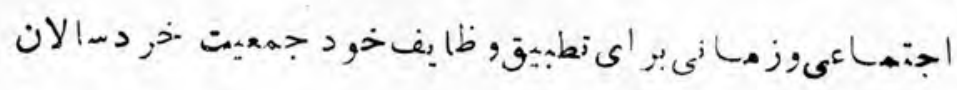

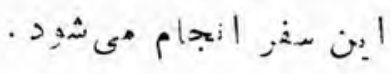

A.

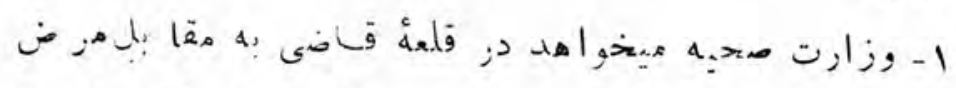

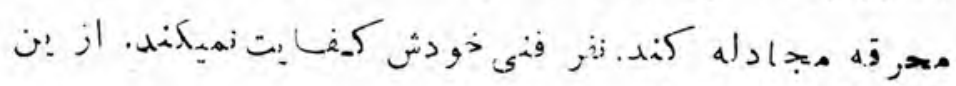

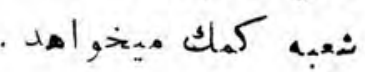

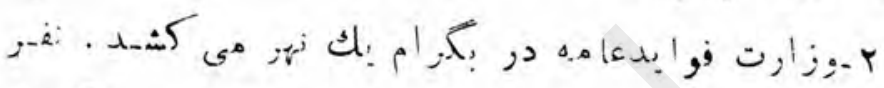

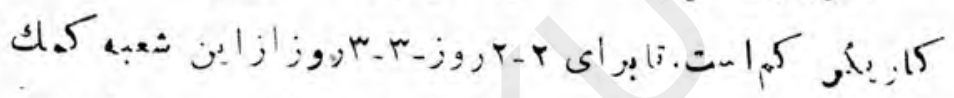
.

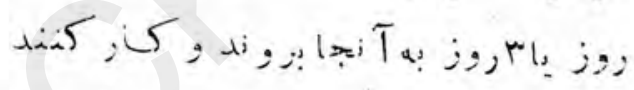

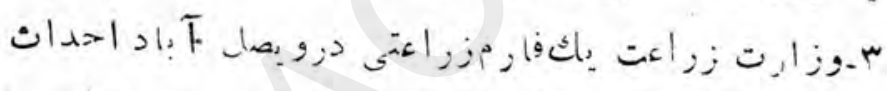

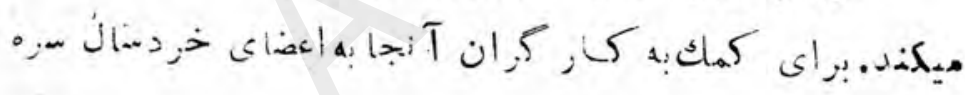

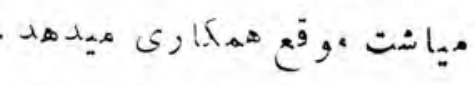

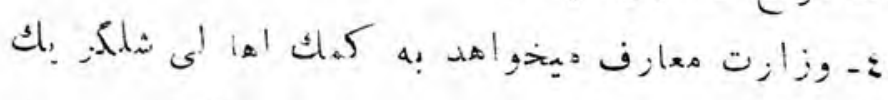

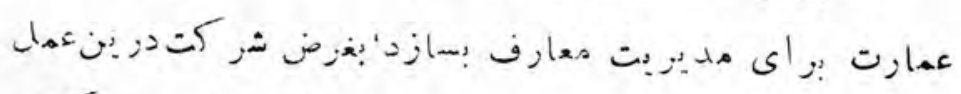

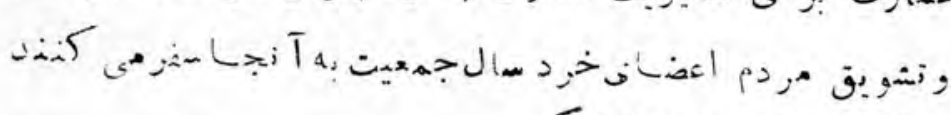

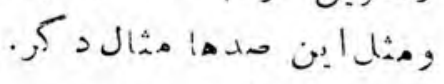

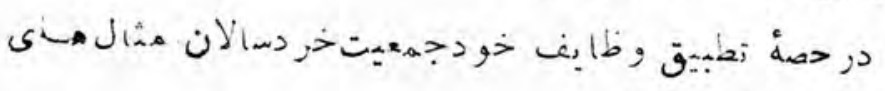

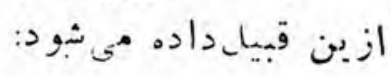


$(1 \cdot r)$

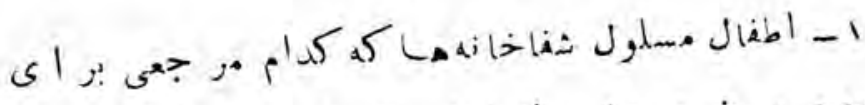

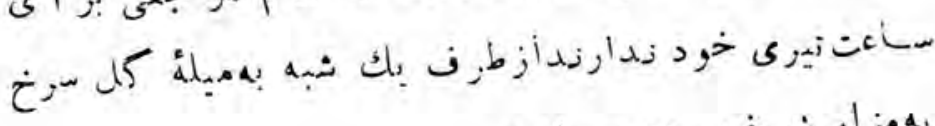

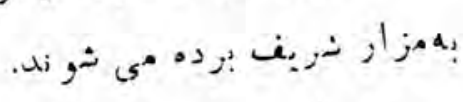

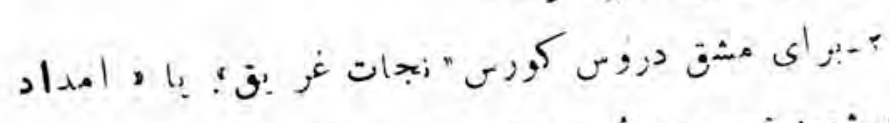

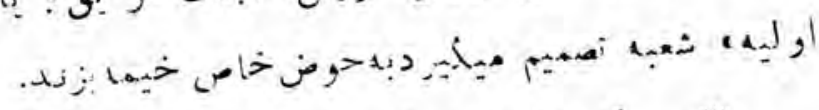

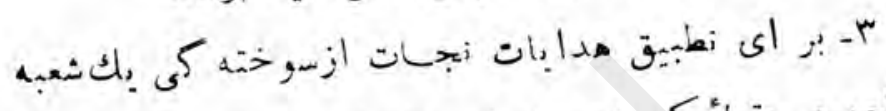

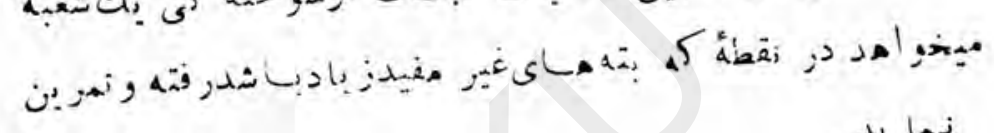
زها بد.

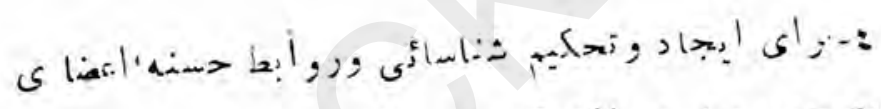

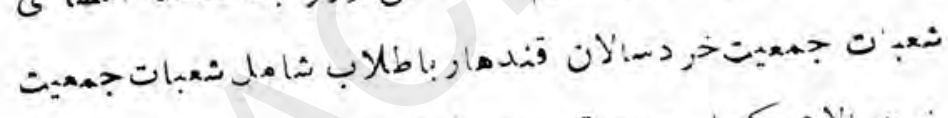

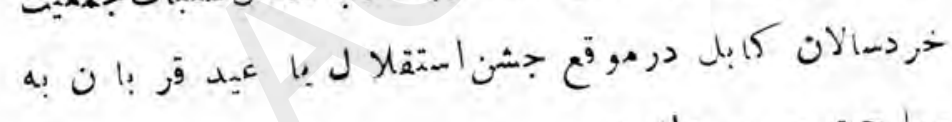
.

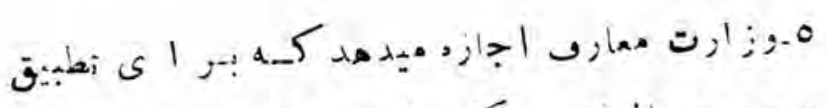

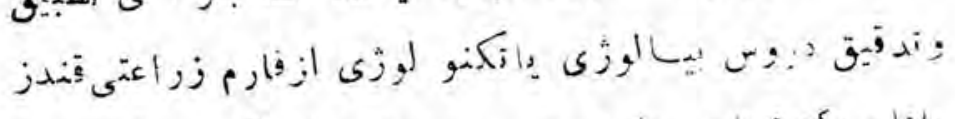

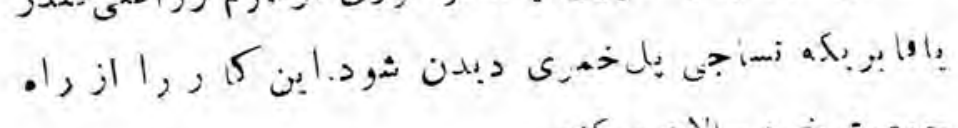
?

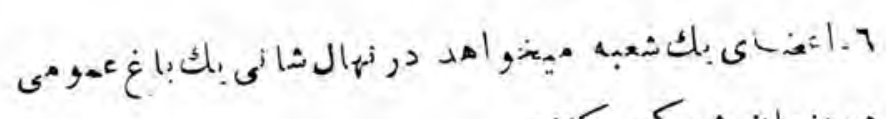

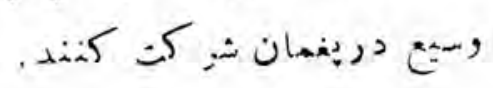


$(1 \cdot r)$

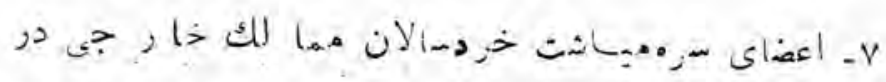

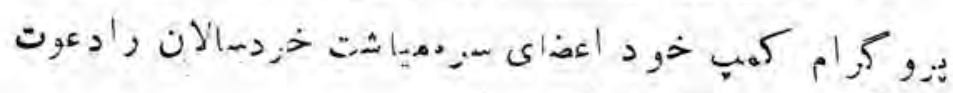

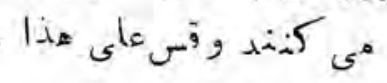

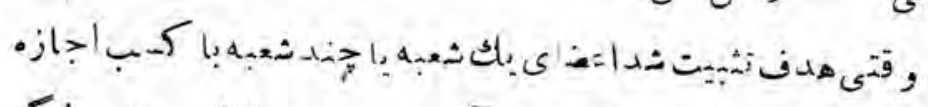

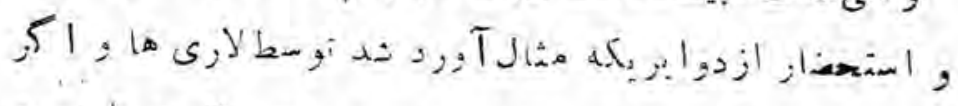

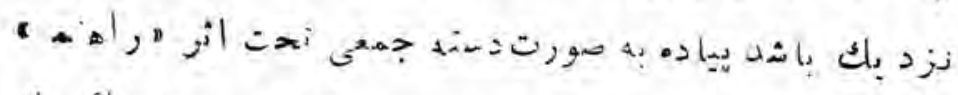

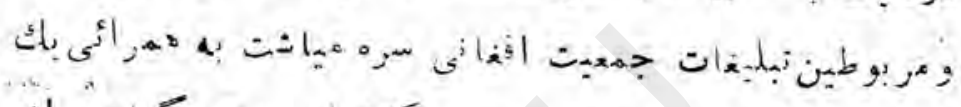

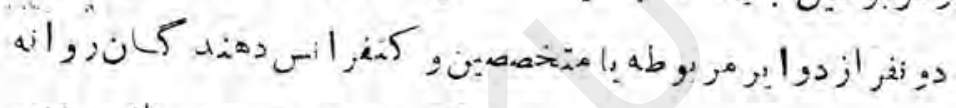

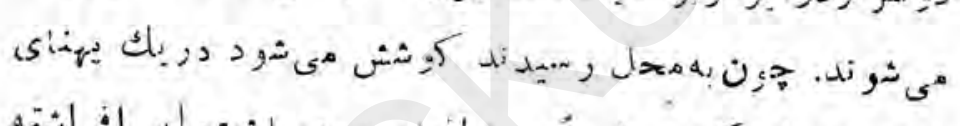

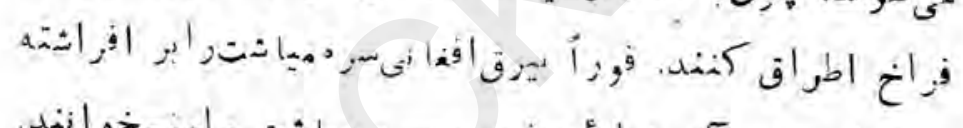

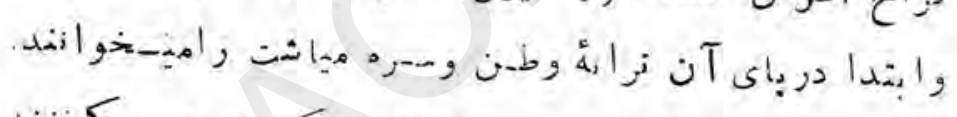

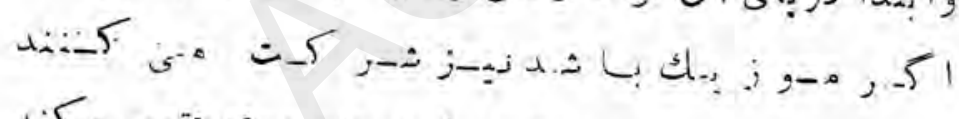

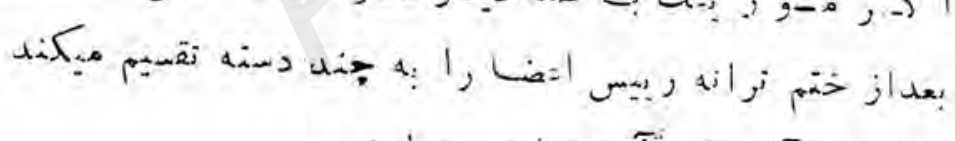

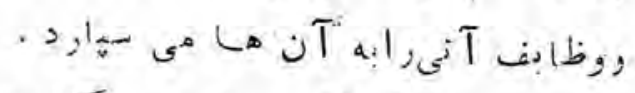

:

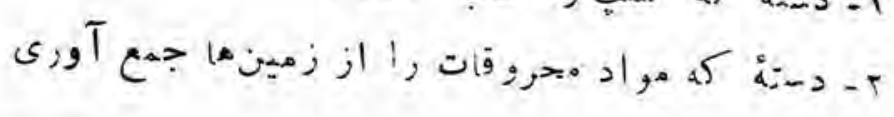

$\lambda i-5$

20

. 
$(i \cdot \varepsilon)$

|

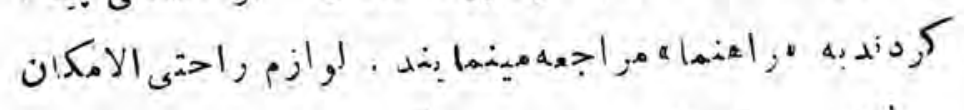

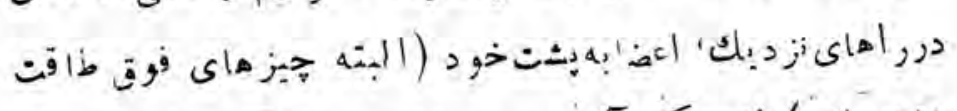

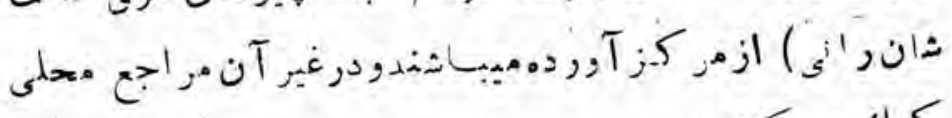

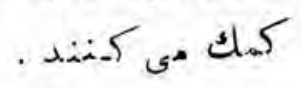

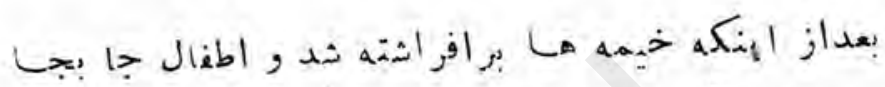

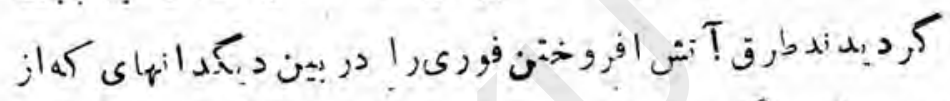

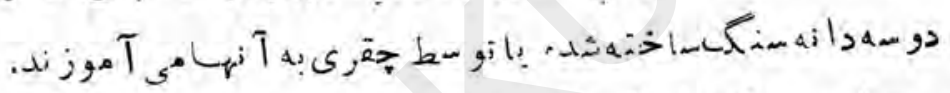

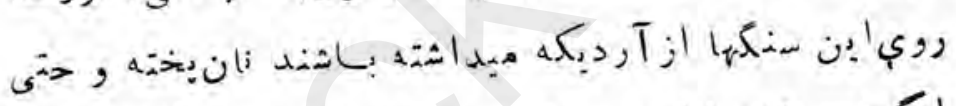

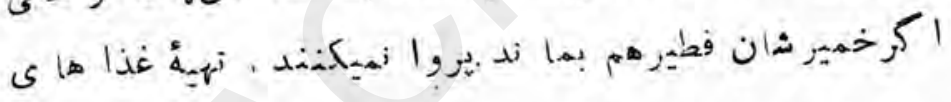

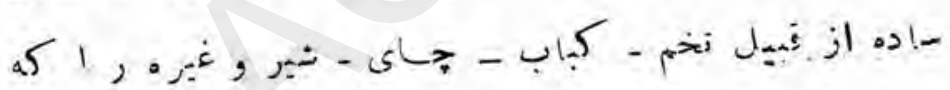

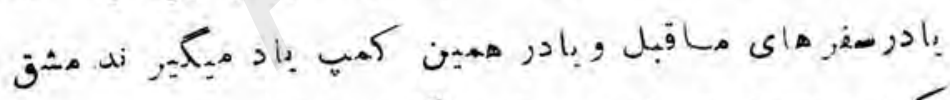

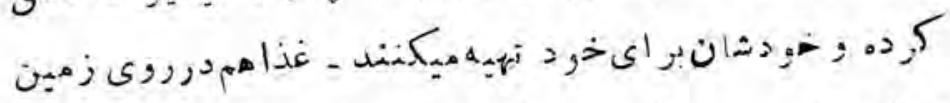

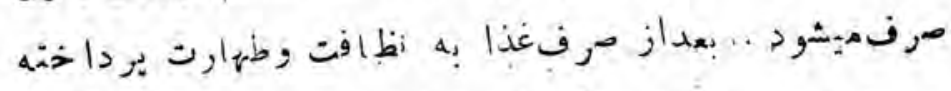

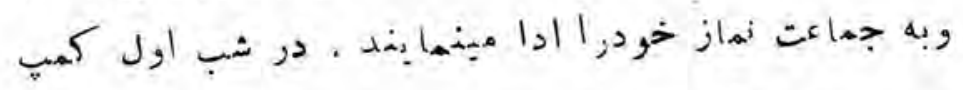

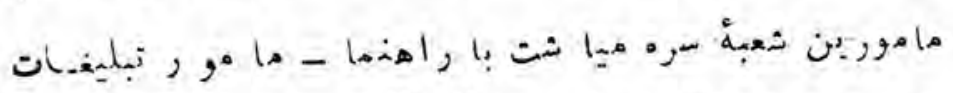

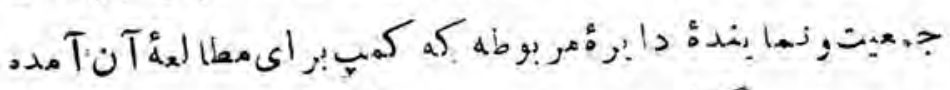

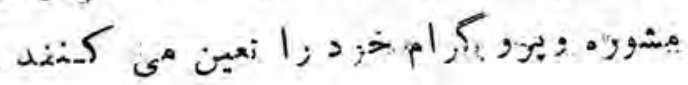




$$
(1.0)
$$

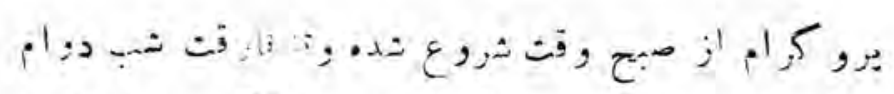

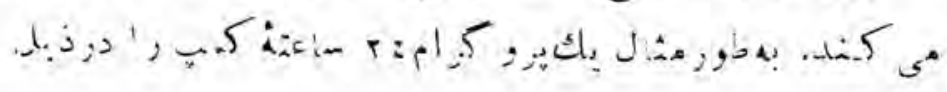
$\because$ :

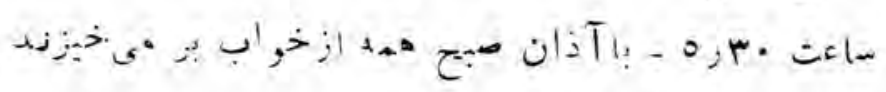

.

An

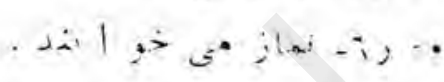

.

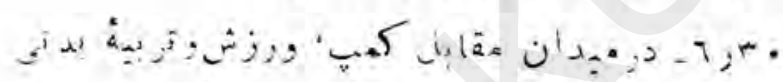

$$
\begin{aligned}
& \text { اجر }
\end{aligned}
$$

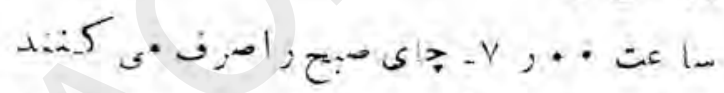

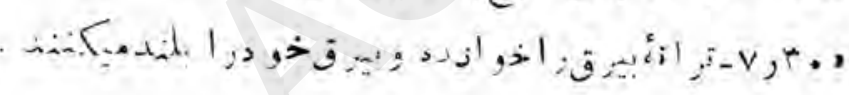

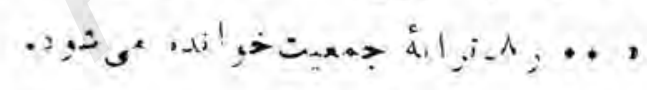

is

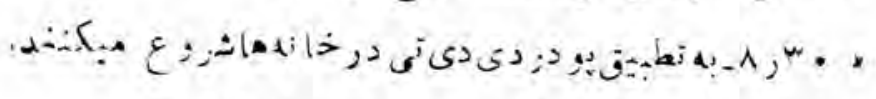

.

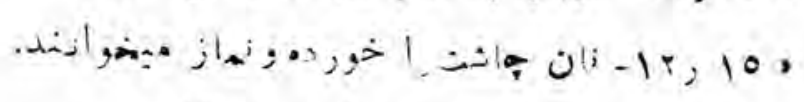

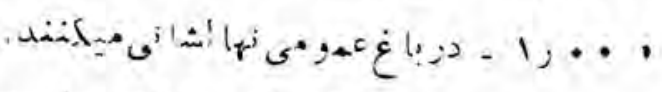

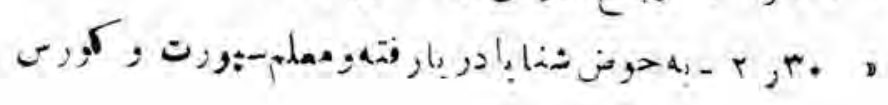


$(1 \cdot 7)$

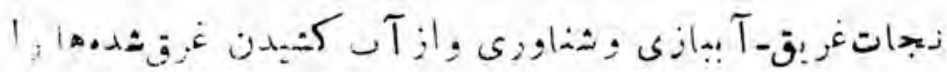

- 1020

ساءت • •

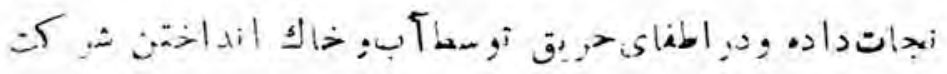

.

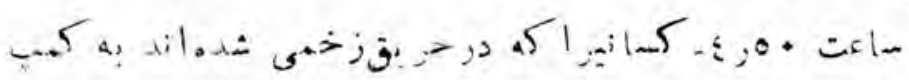

$\sin =\operatorname{lo} i$

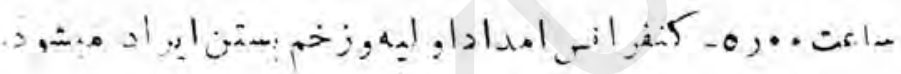

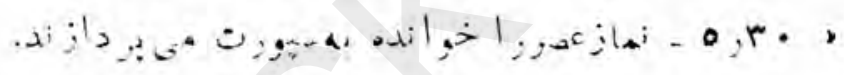

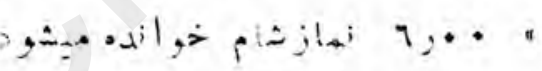

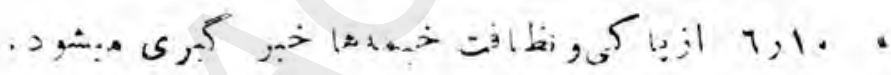

. A

, خمتهنوند

-

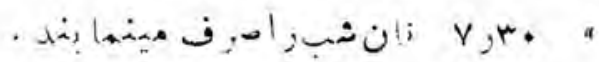

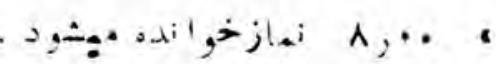

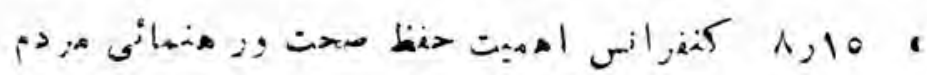

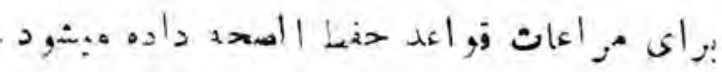


$(1 \cdot \dot{v})$

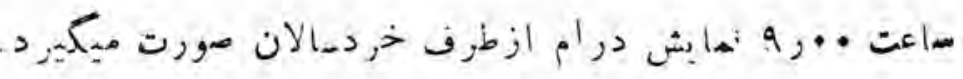

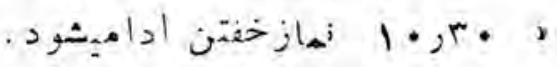

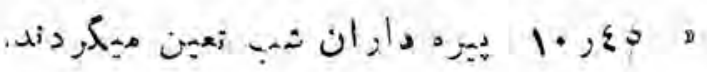

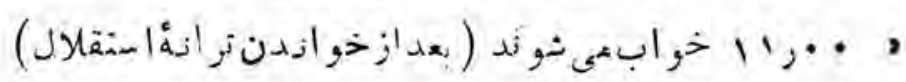

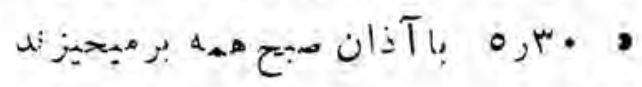

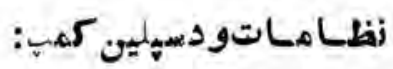

1

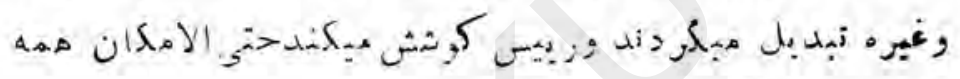

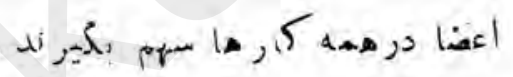

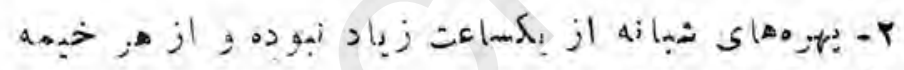

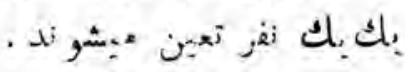

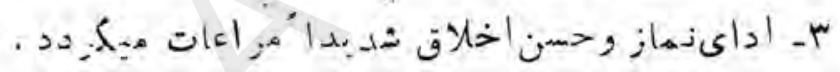

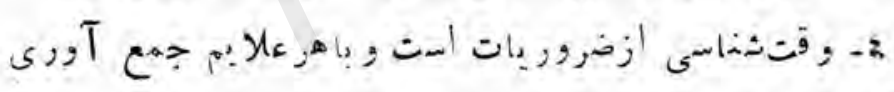

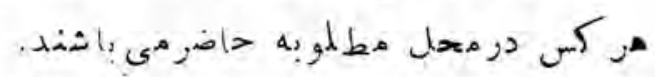

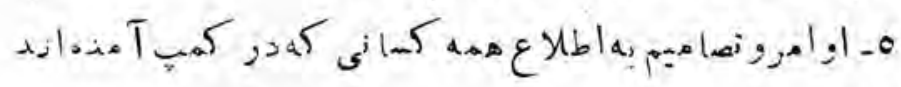

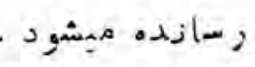

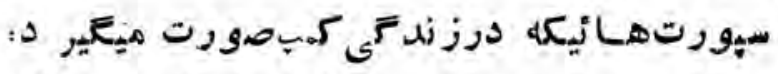

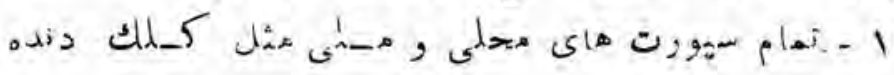

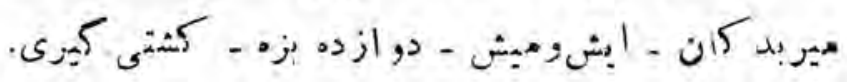




$$
(1 \cdot \wedge)
$$

ז- تمام سهورت هاى بين المهلمى هثل فت بال ــ واليبال

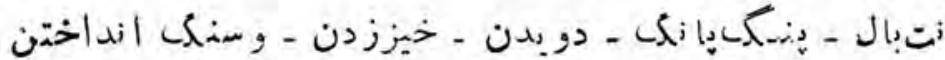
جوجنسو-بكسوغيروه. كورسهائيكلة در كمب اجر ا ميثود .

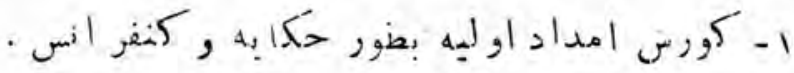

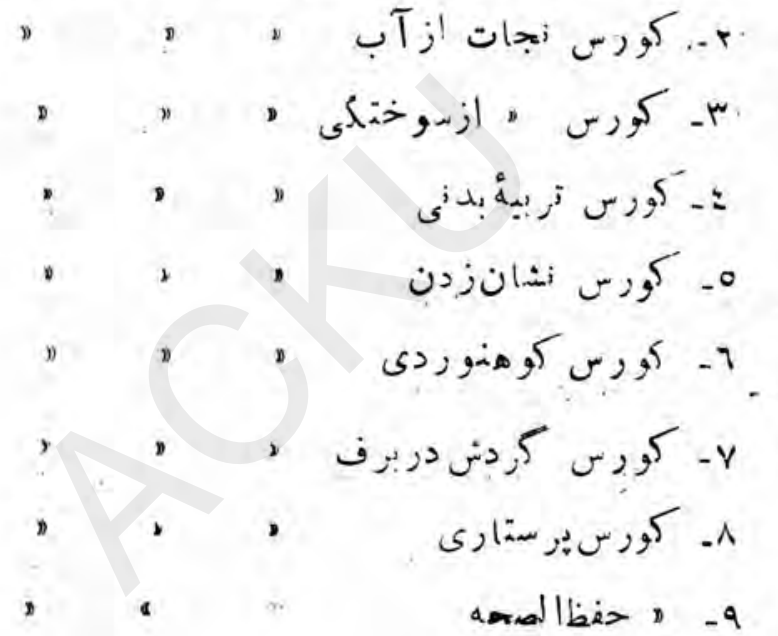

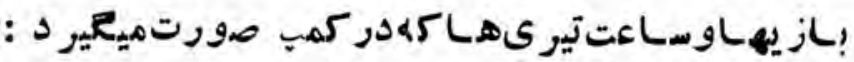

$$
\begin{aligned}
& \text { - } \\
& \text { r r بخت: بزن. } \\
& \text { r. } \\
& \text { - }
\end{aligned}
$$




$$
(1.9)
$$

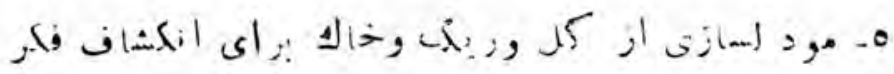

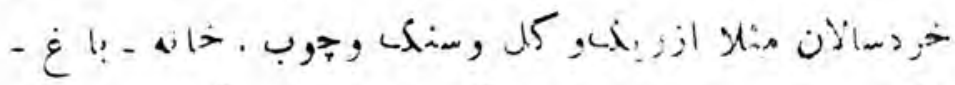

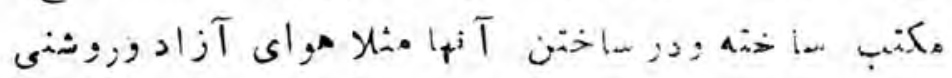

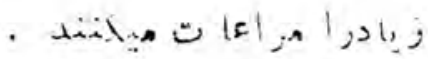

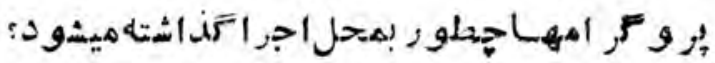

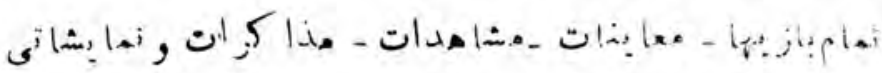
.20, كا.

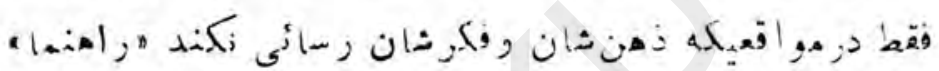

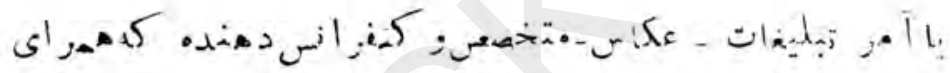

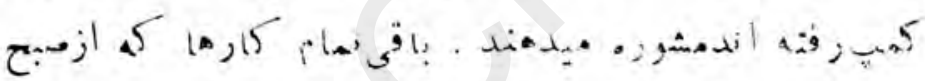

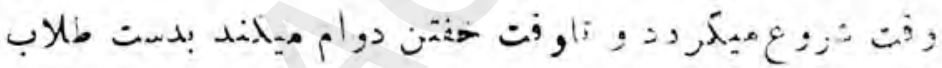

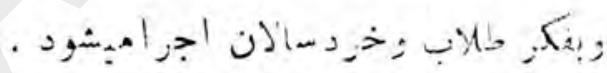

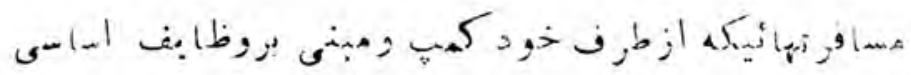

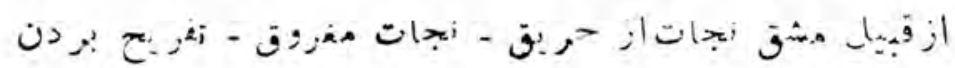

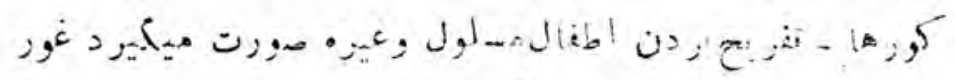

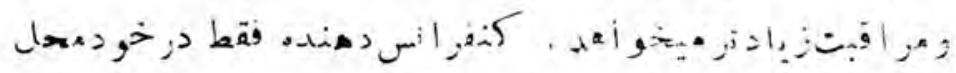

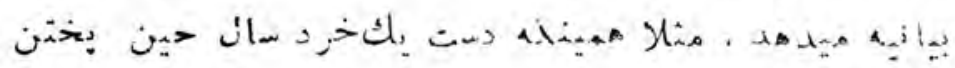
الن 
(11.)

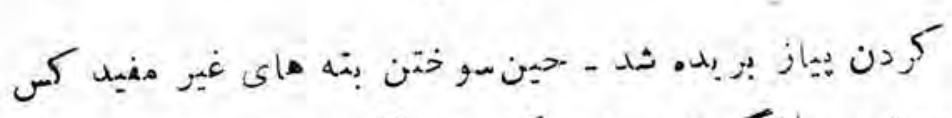

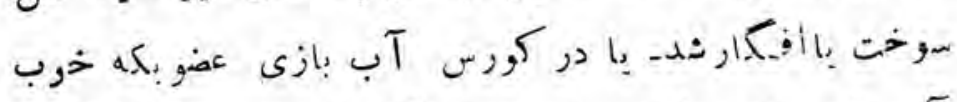

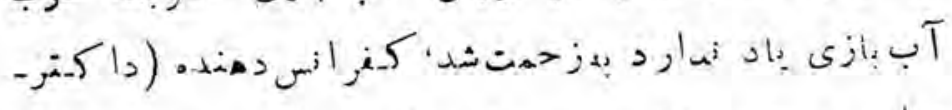

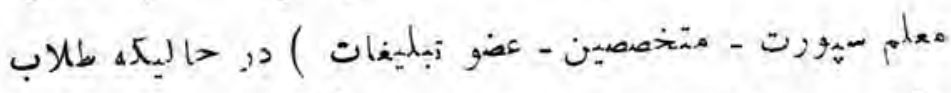

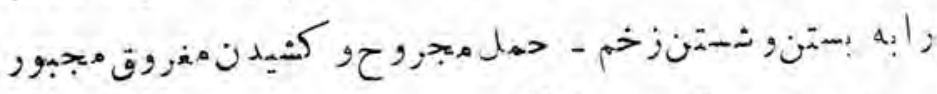

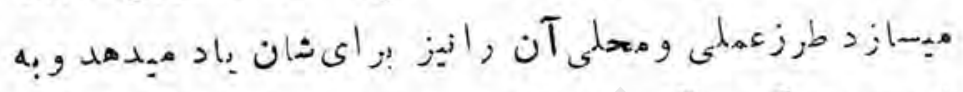

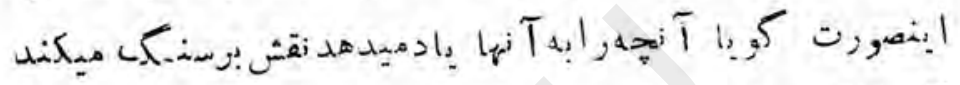

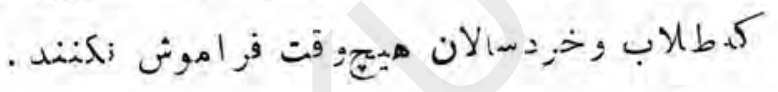

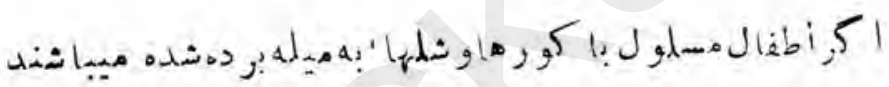

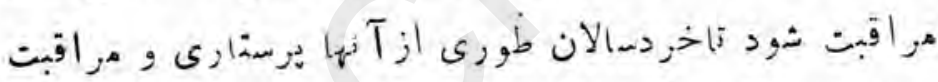

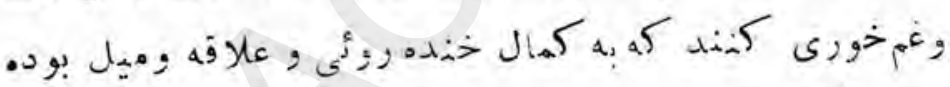

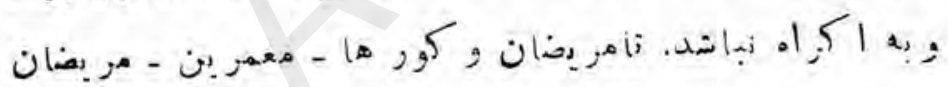

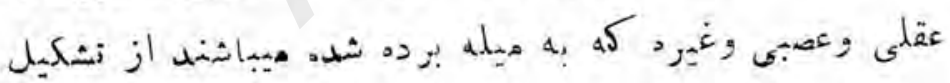

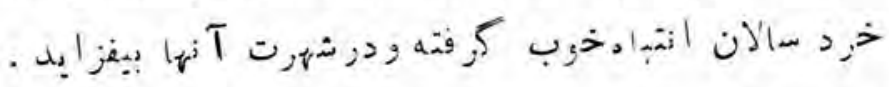

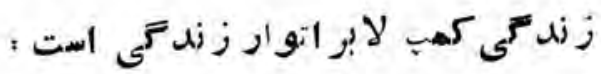

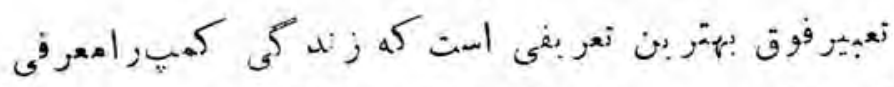

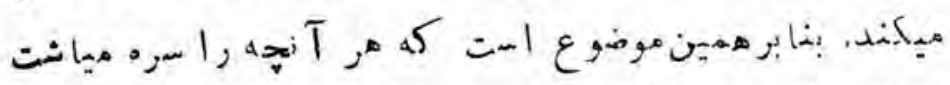

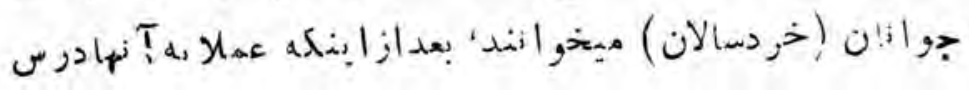


(111)

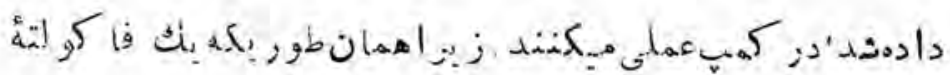

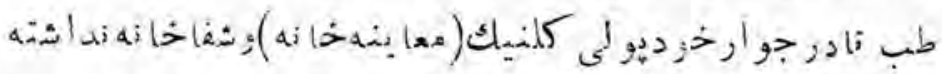

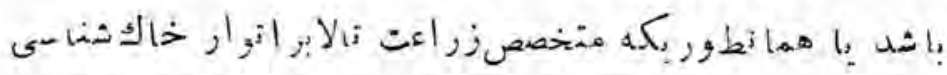

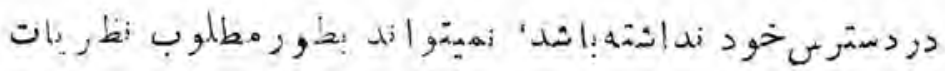

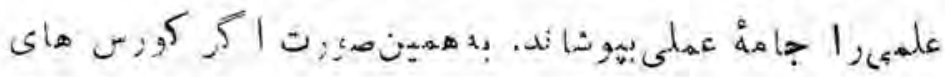

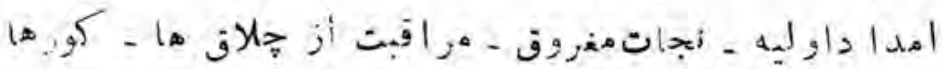

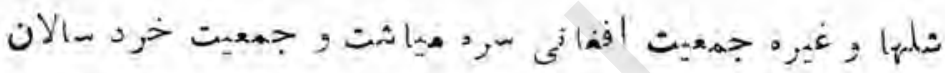

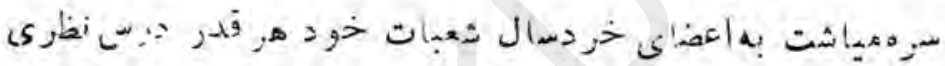
بـ

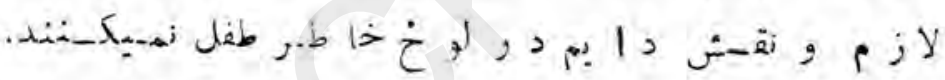

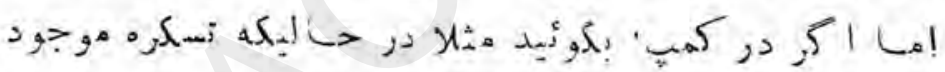

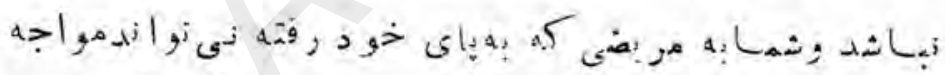

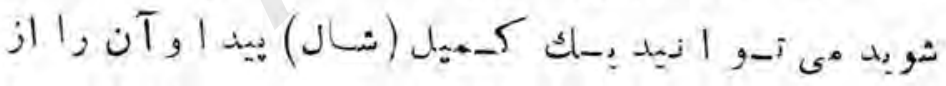

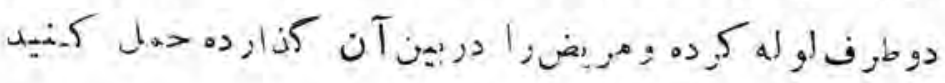

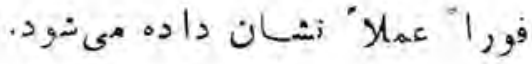

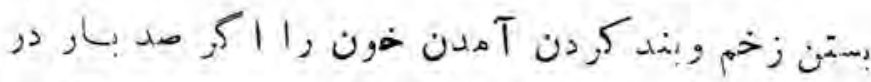

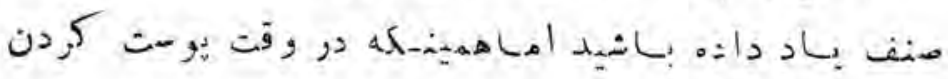

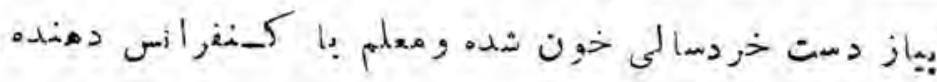


$(11 \%)$

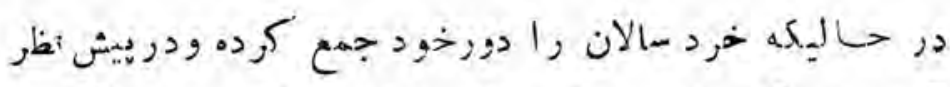

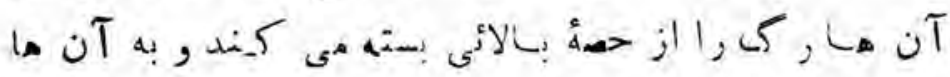

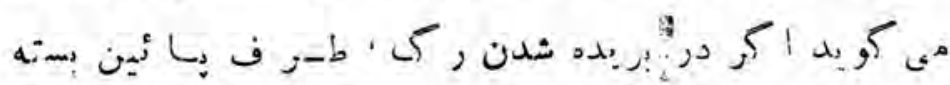

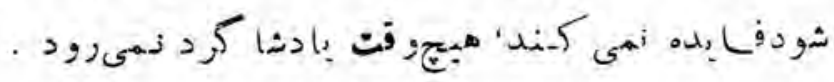

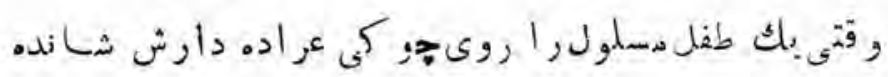

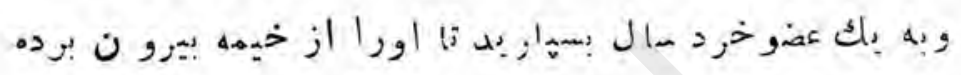

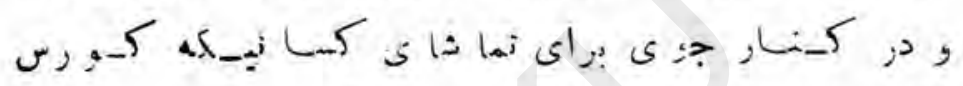

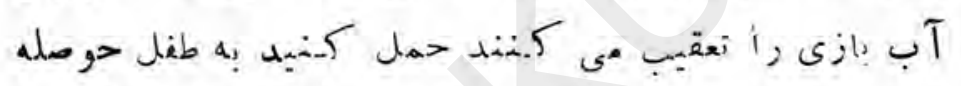

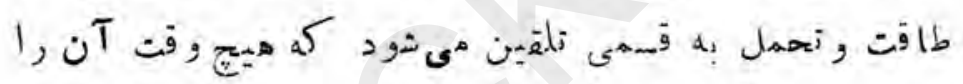

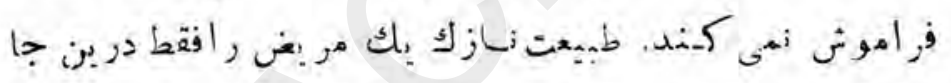

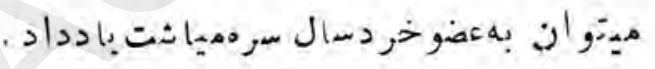

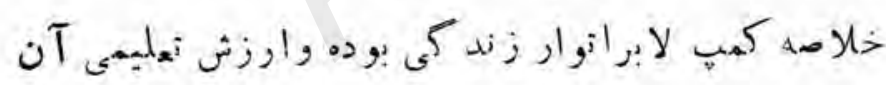

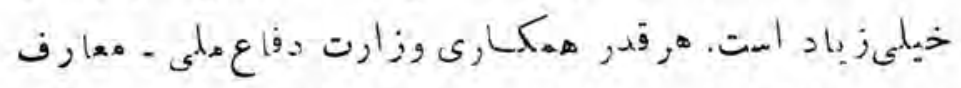

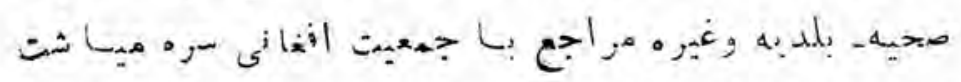

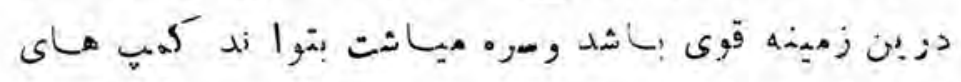

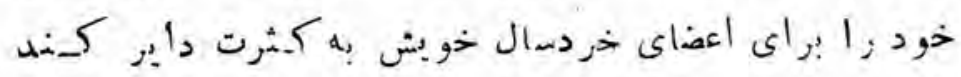

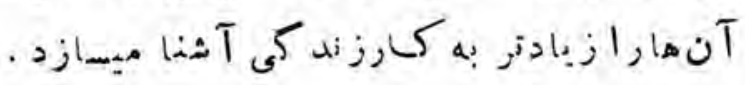

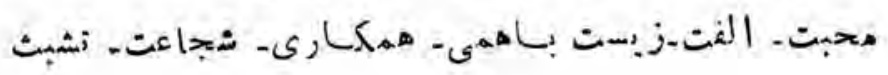


$(1, r)$

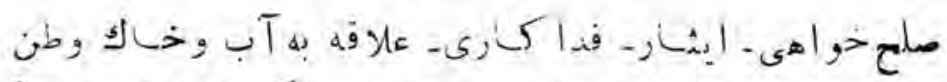

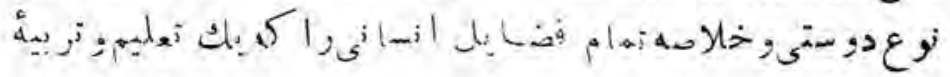

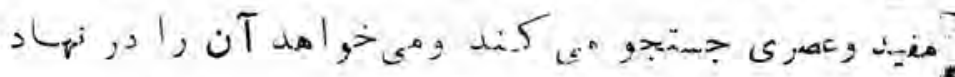

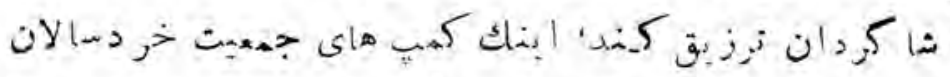

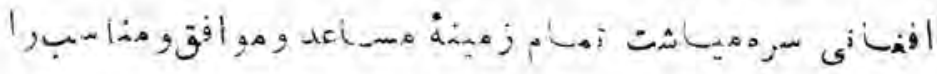

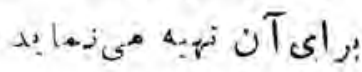

مر اجمت كمب: :

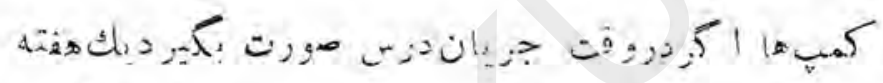

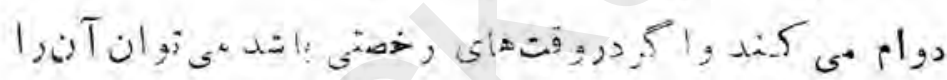
|

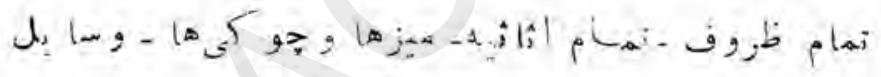

i

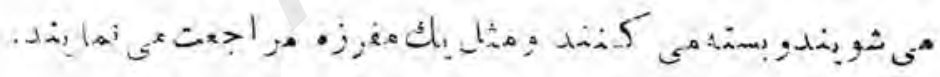

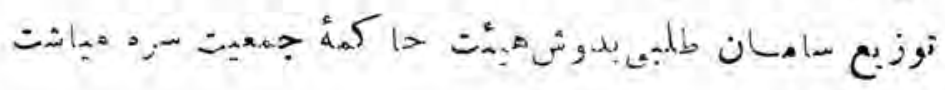

خردمالان أست

اعاشهدر كمي:

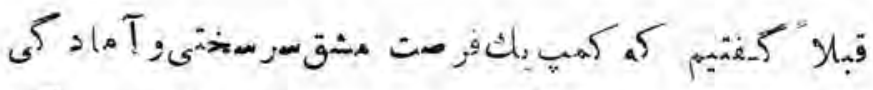

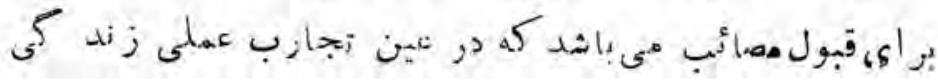




\section{(iiz)}

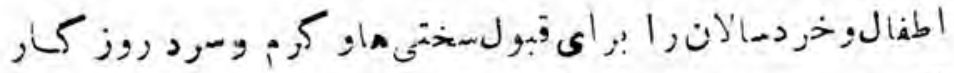

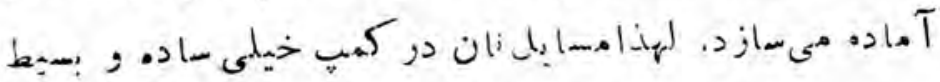

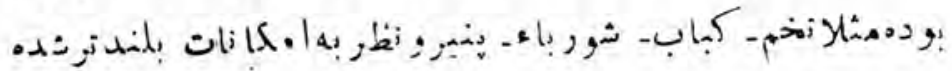

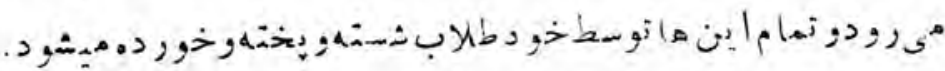

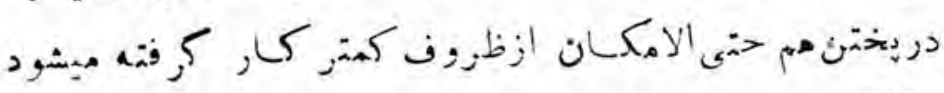

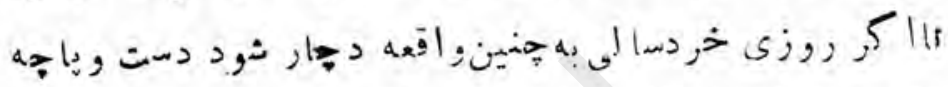

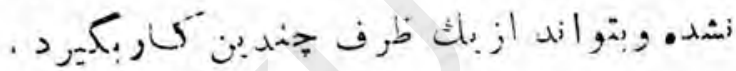

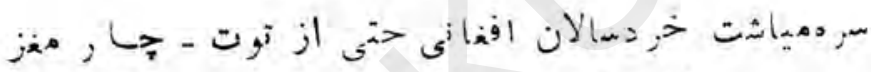

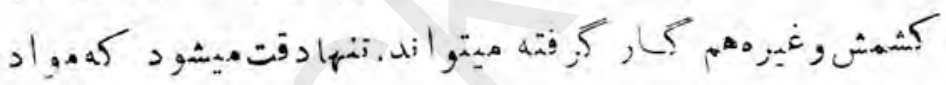

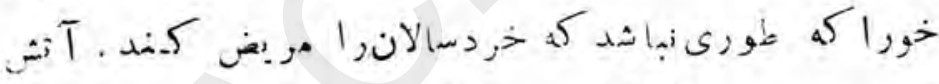

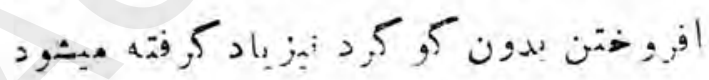

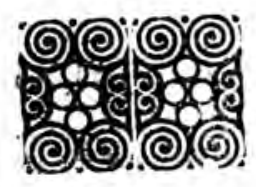


(110)

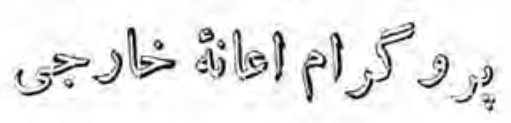

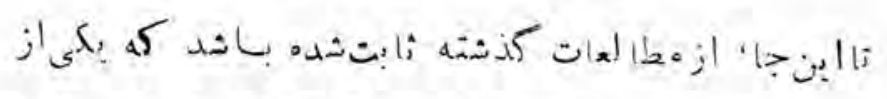

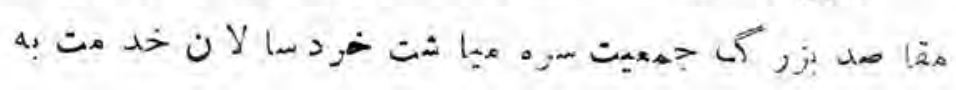

$=-1$ ج

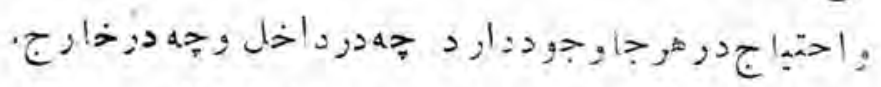

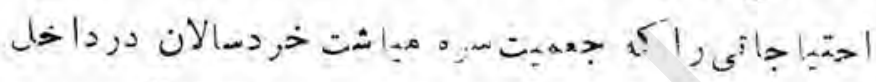

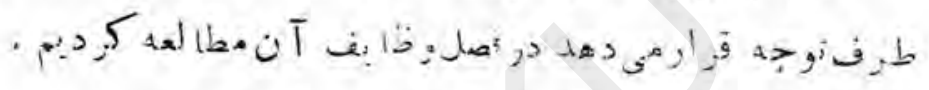

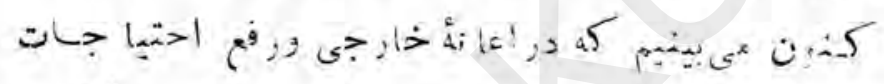

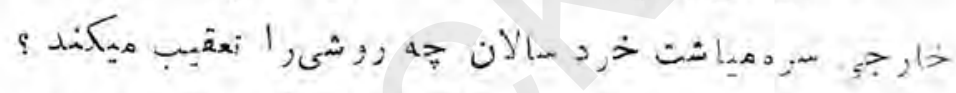

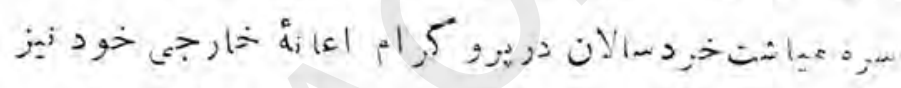

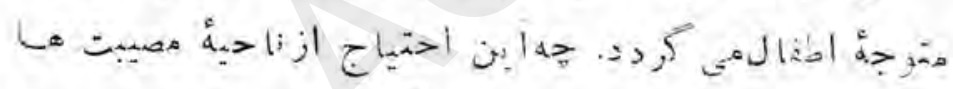

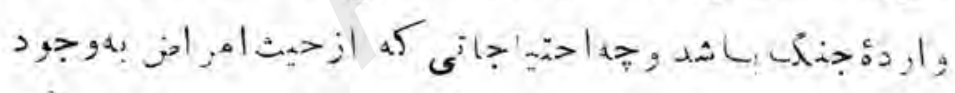

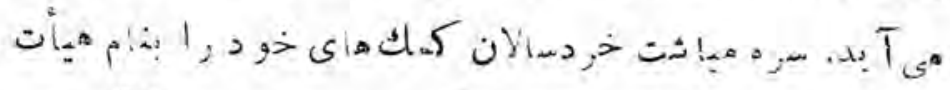

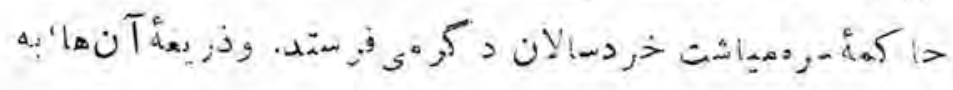

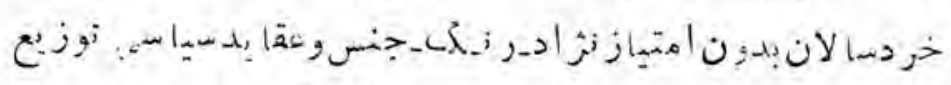

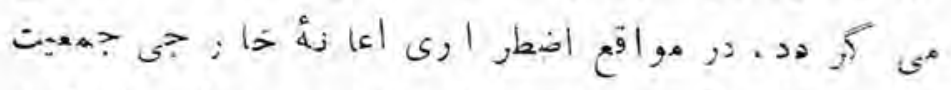

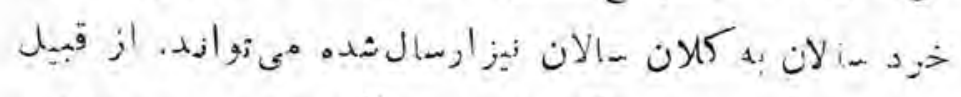

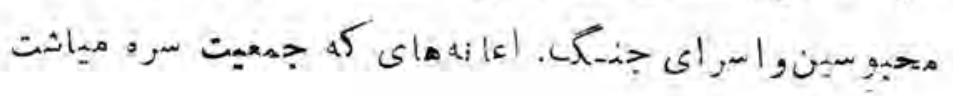


(119)

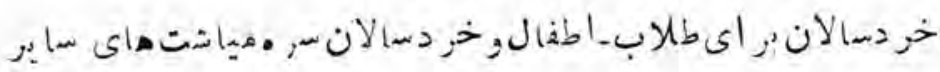

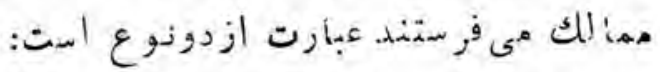

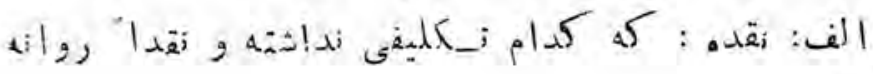
مئودم.

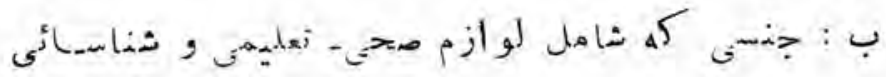

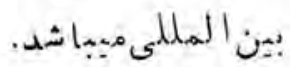

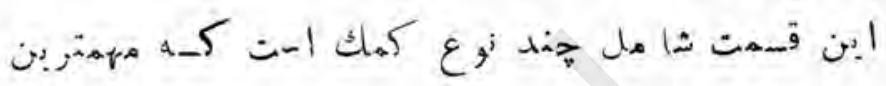

$$
\text { آن }
$$

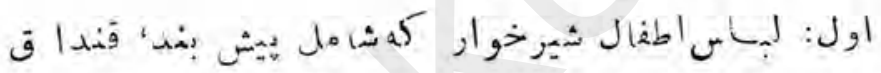

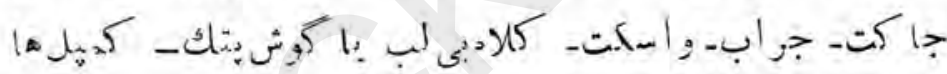

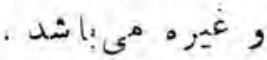

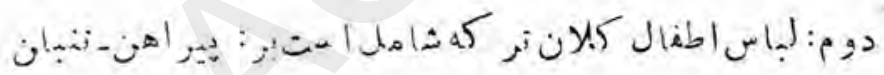

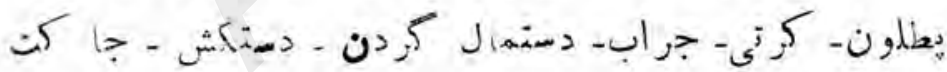

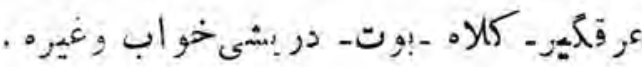

سوم: اغضاى هصنوعى ازقبيل دمتــ مإىنعيره

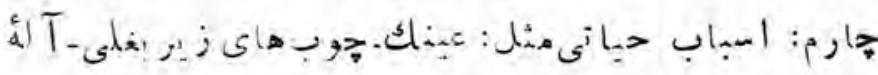
مكبر الصوت برأى كرها- ادو به وغيره.

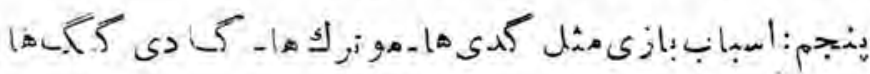

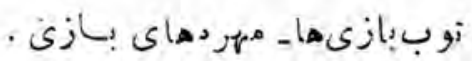


(1iv)

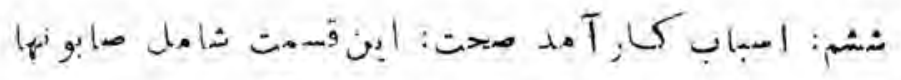
a

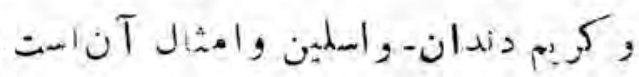

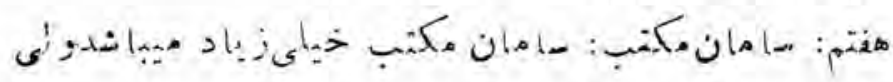

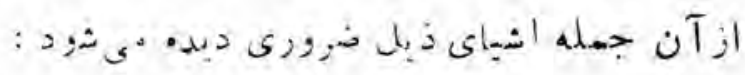

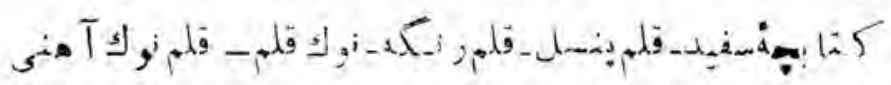

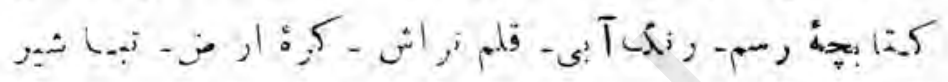

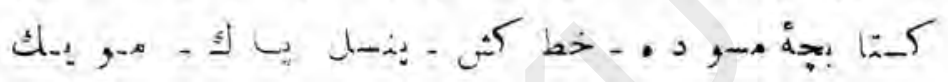

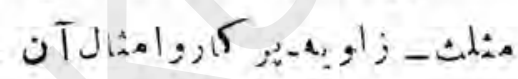

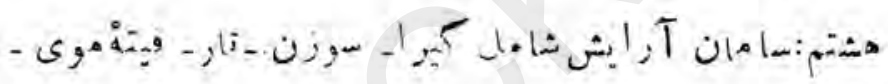

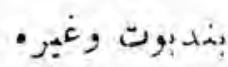

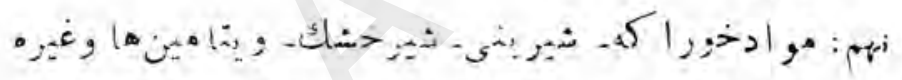

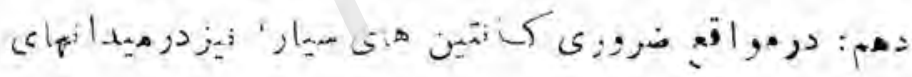

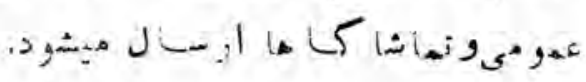
امداثجطور ارسال ميعر دد؟

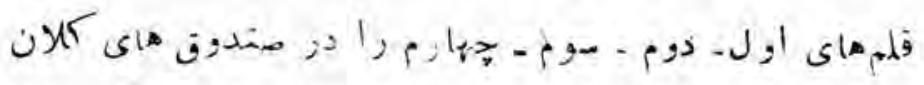

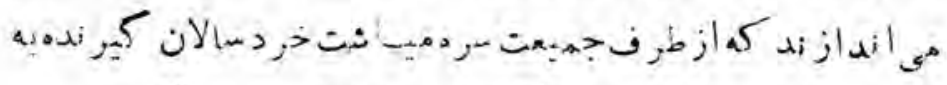
. 
(111)

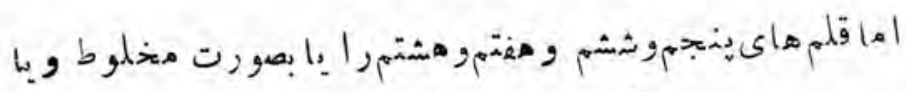

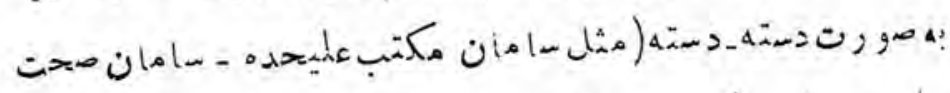

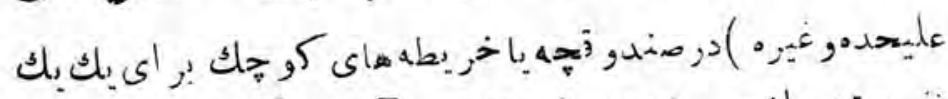

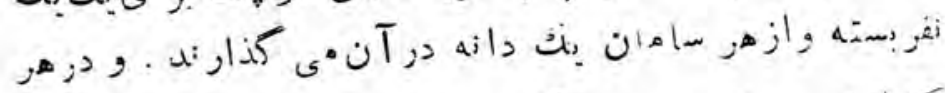

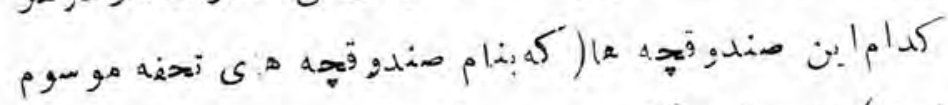

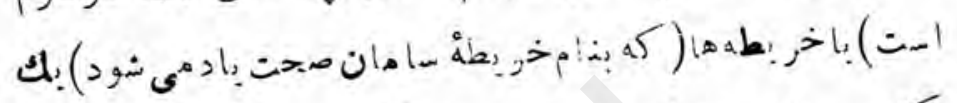

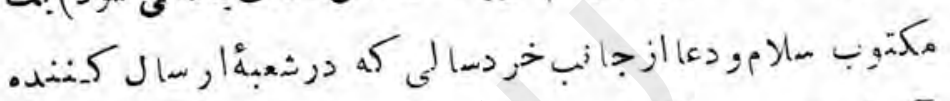
آ

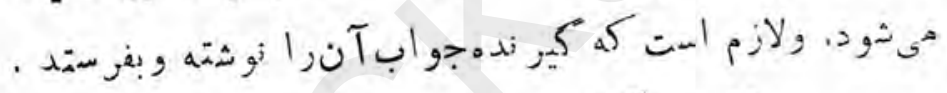

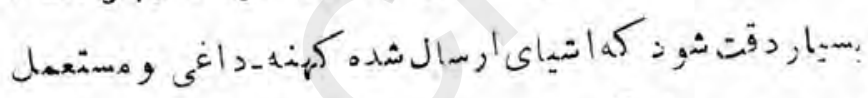

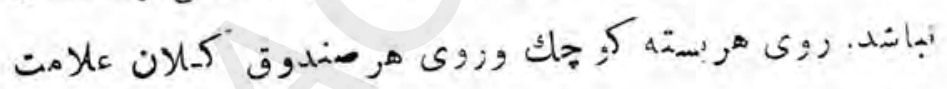

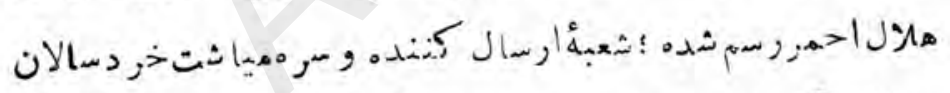

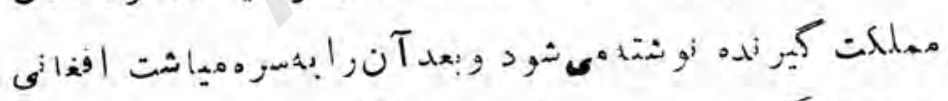

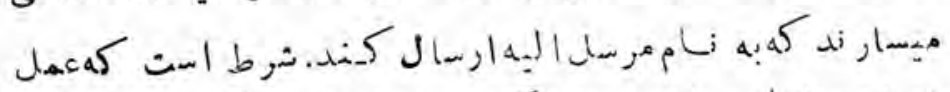

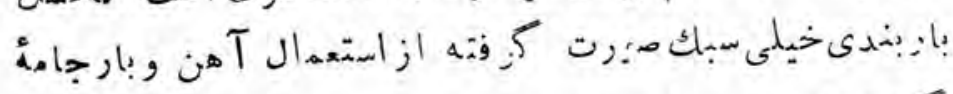

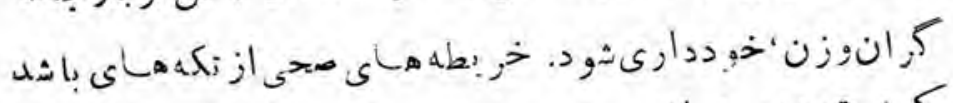

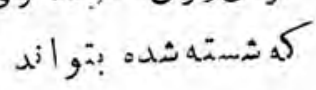

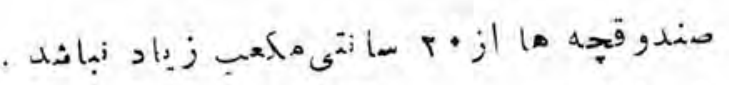

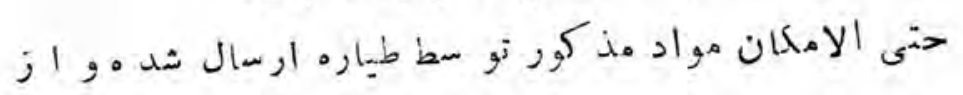


(119)

ن

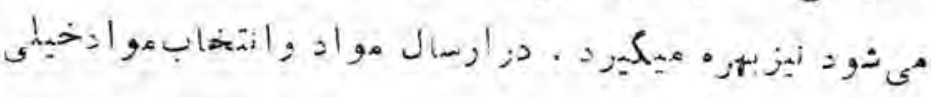

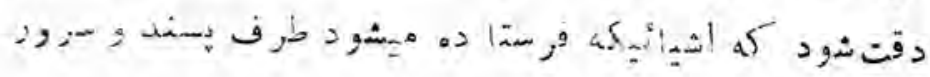

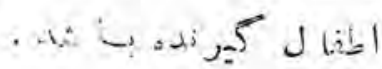

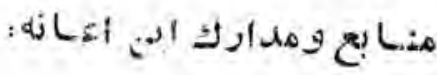

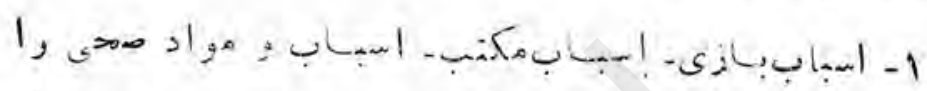

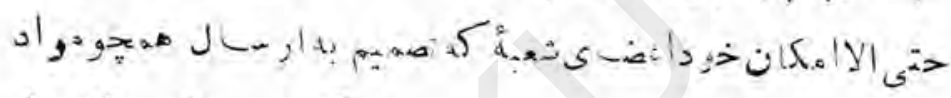

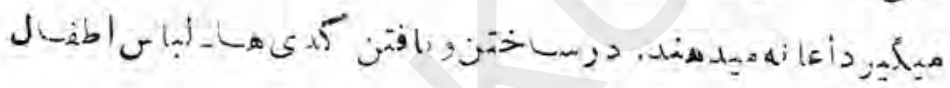

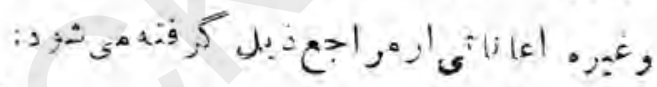

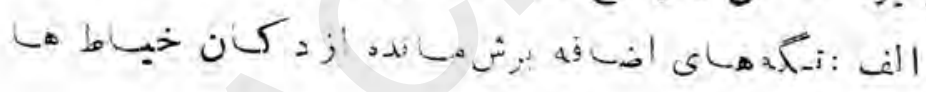
ف ب: جن arivelo

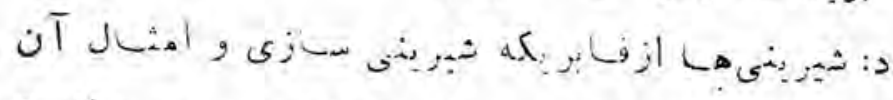

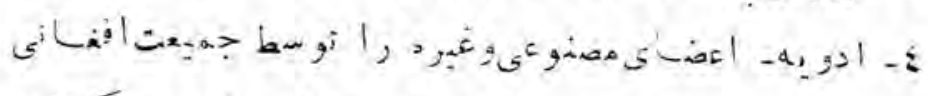

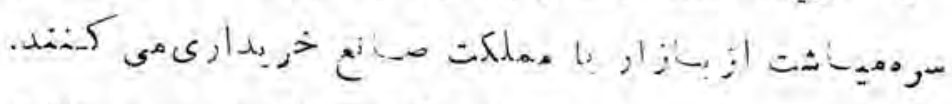

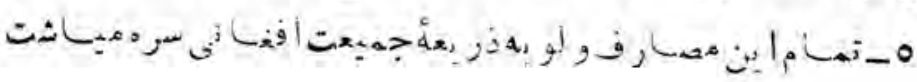




$$
(1+\cdot)
$$

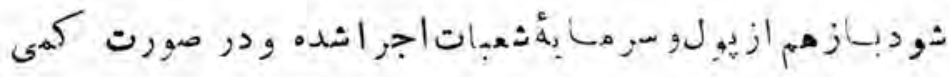

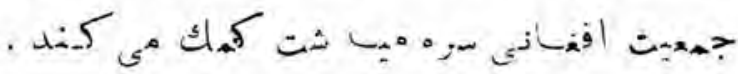

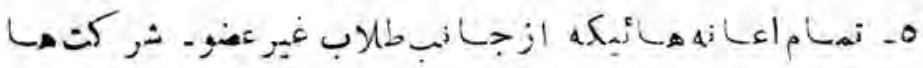

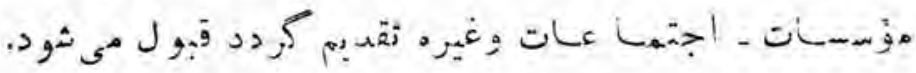

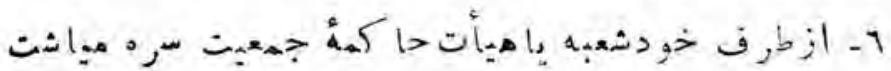

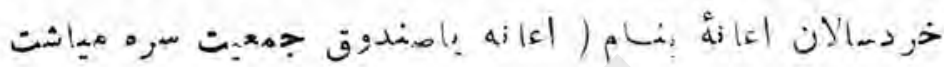

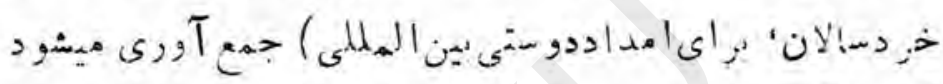

كa

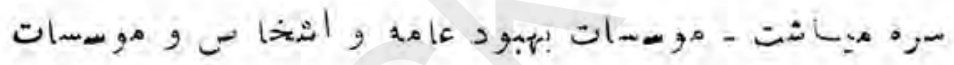

uidis.

آنها

ارزان

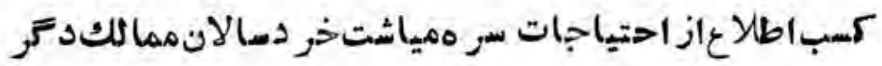

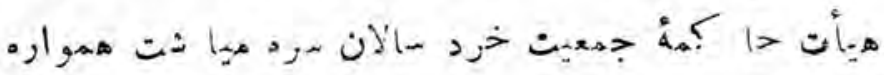

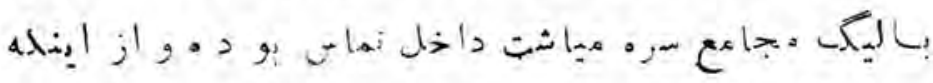

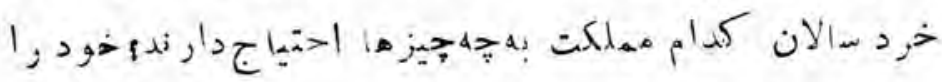

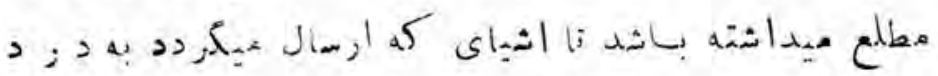

. 
$(1+1)$

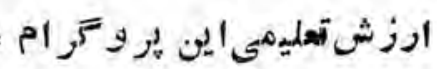

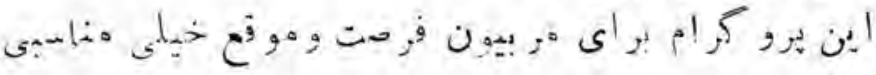

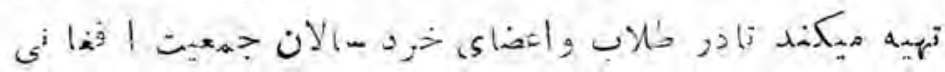

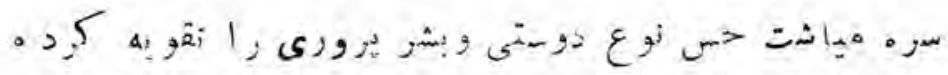

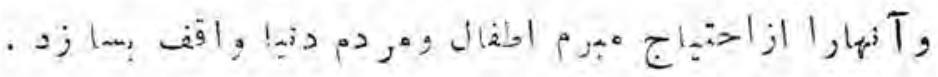

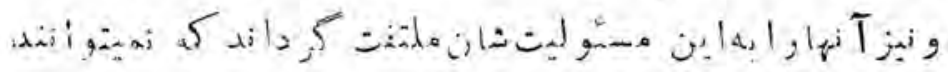

درقبال له

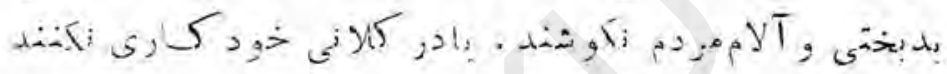

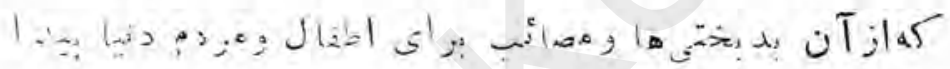

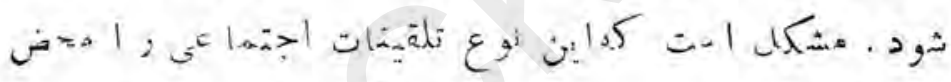

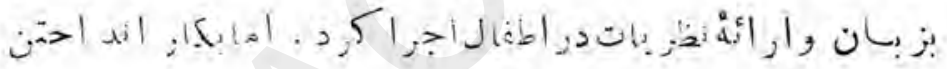

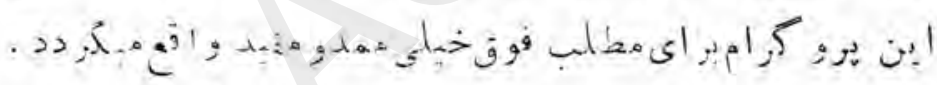

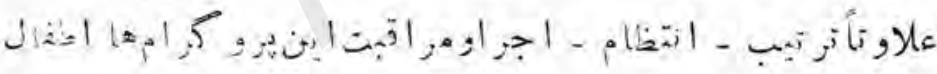

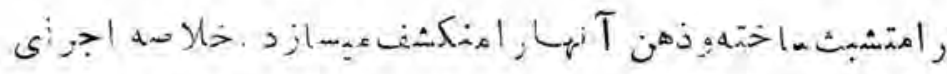

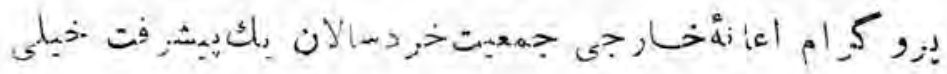

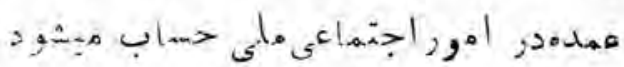


$(i r)$

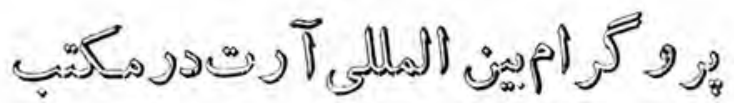

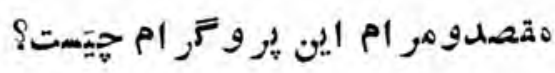

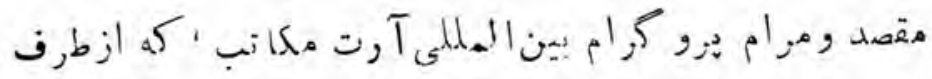

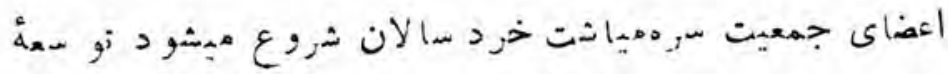

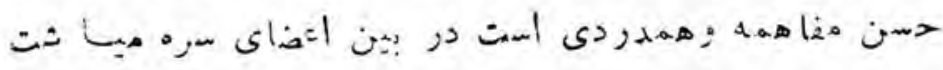

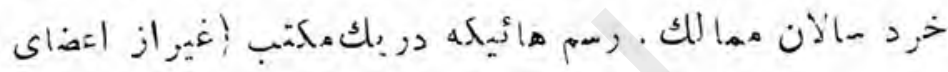

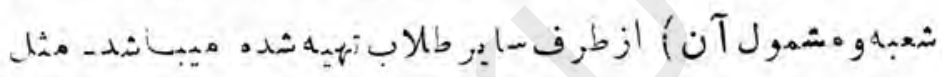

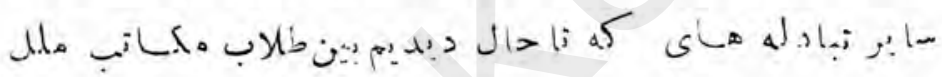

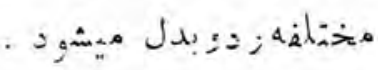

اين هرو كر ام جطور كار ميكند ؟

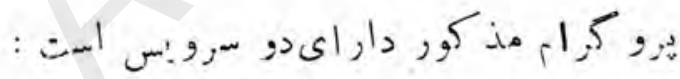

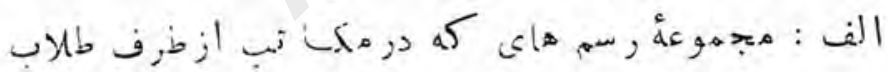

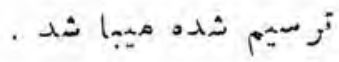

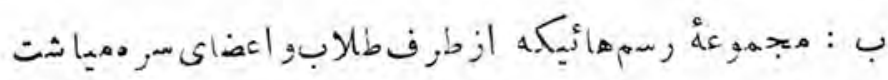

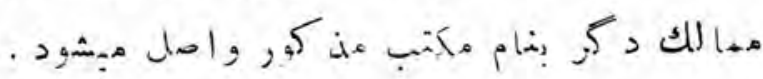

جطوروسم هار ا جمع آنورى ميكندي

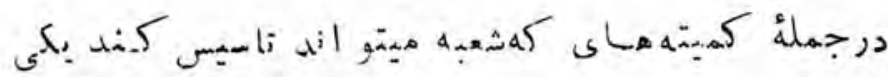




$$
(1+r)
$$

هـ

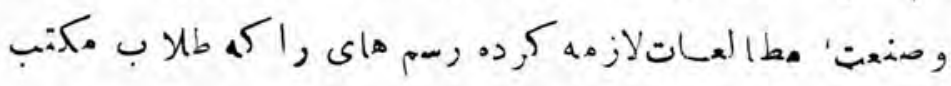

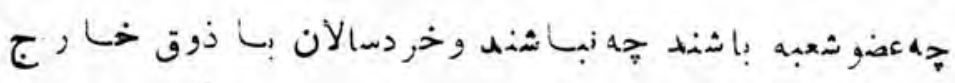

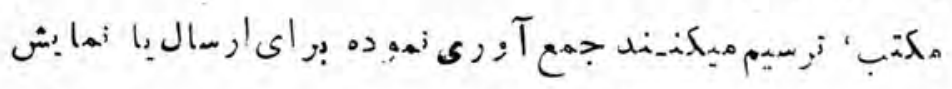

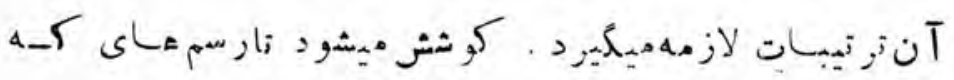

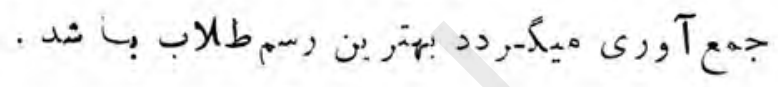

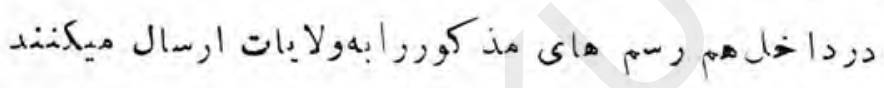

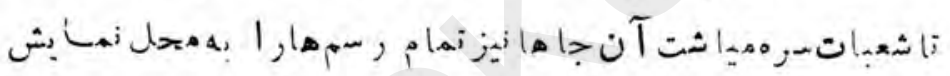

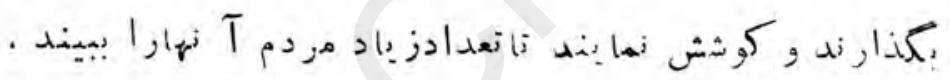

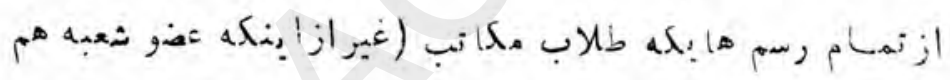

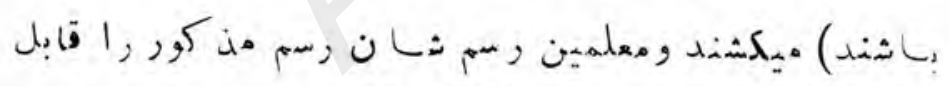
زها.

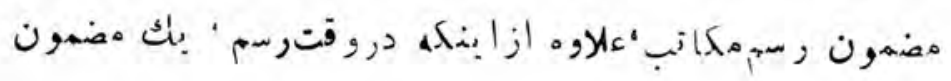

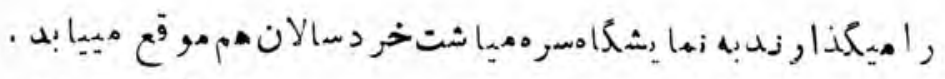

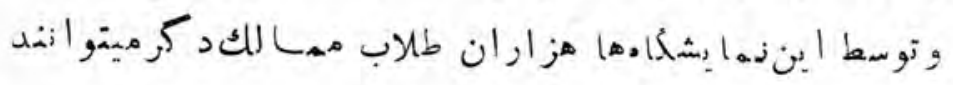

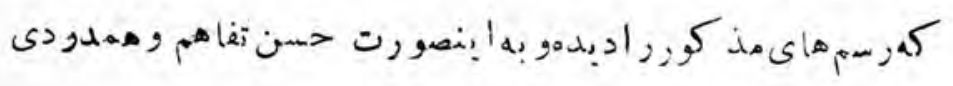

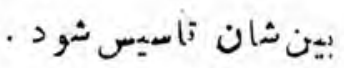


$(1+\varepsilon)$

كدامكس سهم كر فته ميتو اندي

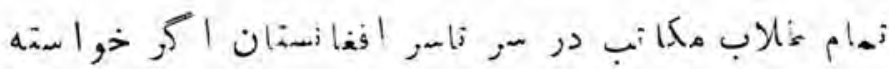

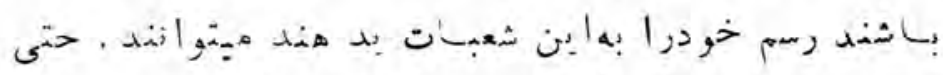

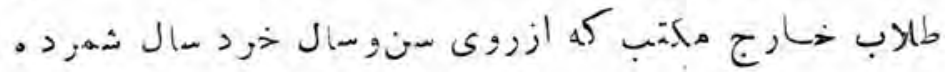

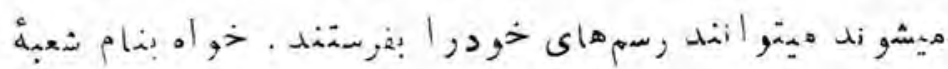

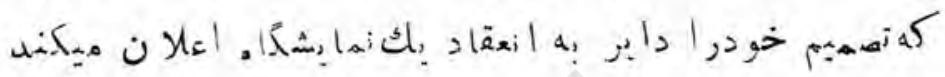

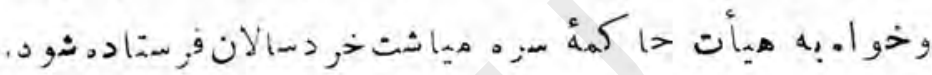

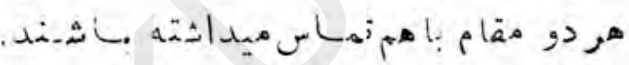
يك آدمجندوسمفرستادهميتو اند ؟

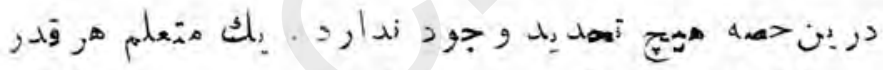

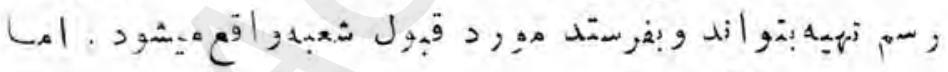

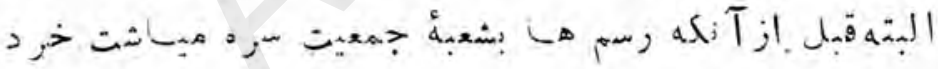

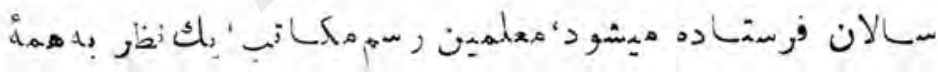

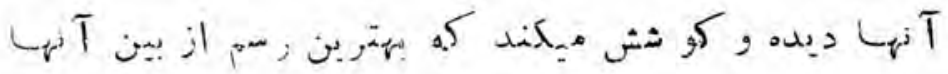

د

آياهررقمرسم فرستادهثهميتو اند ؟

بلى ضرور زيست كه ه

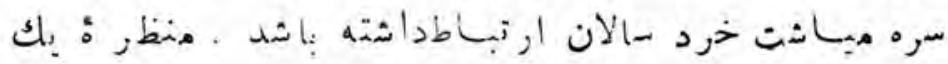




$$
(1,0)
$$

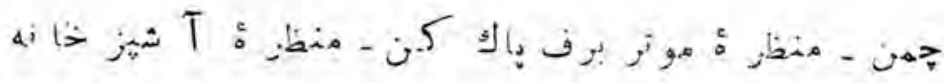

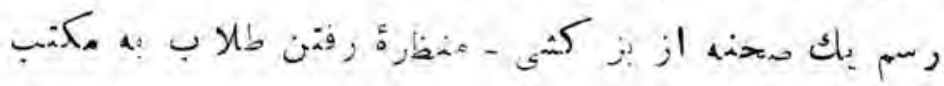

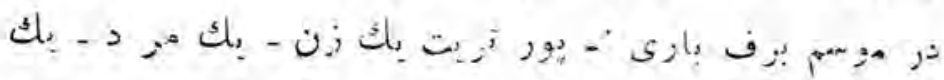

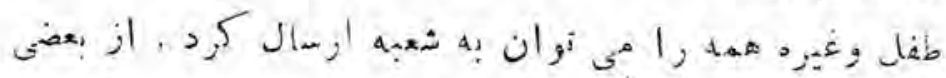

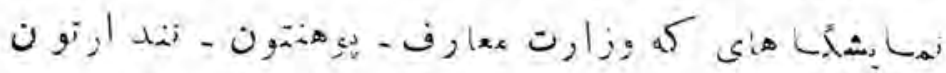

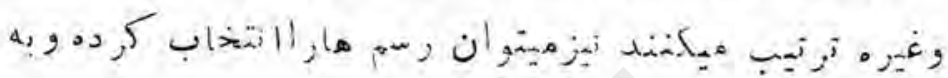

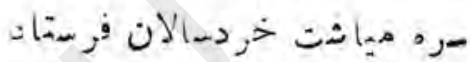

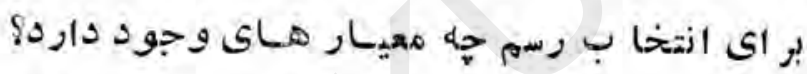

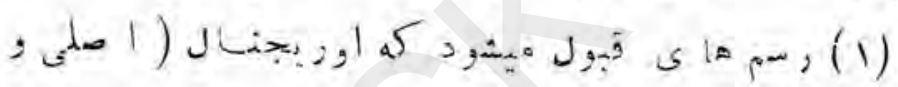

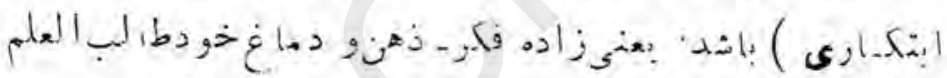

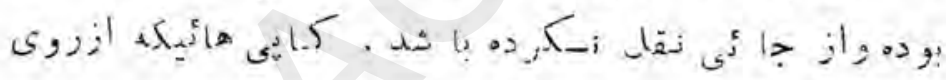

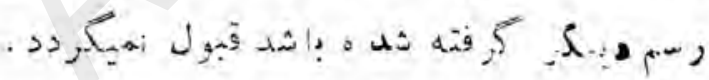

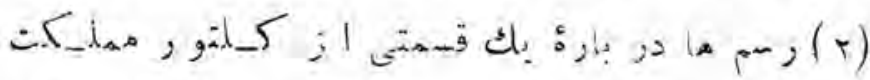

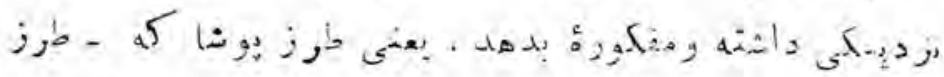
خور اك ك- طزيز . ماند

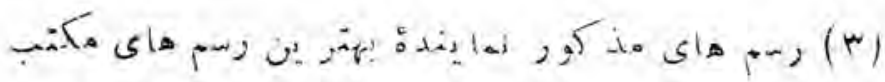
إ, سال ك S. 
$(1 Y 7)$

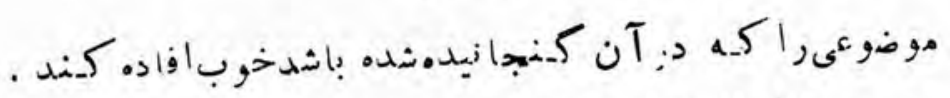
رسم بجهاندازهبـاشدو هو

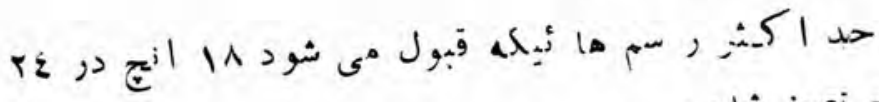

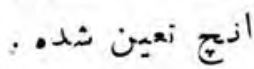

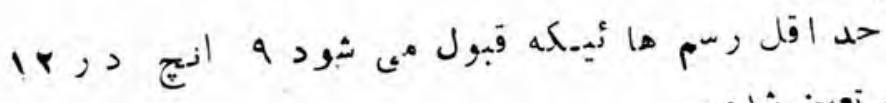

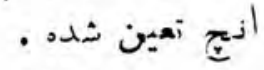

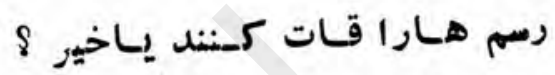

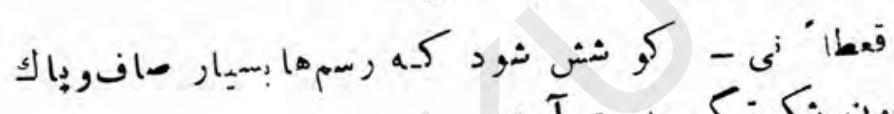

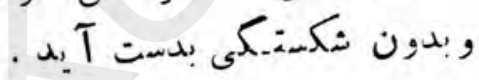

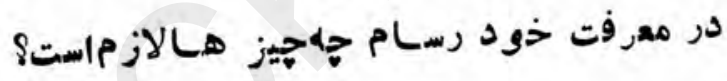

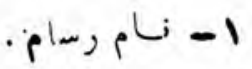

- re-r

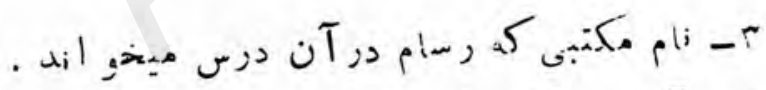

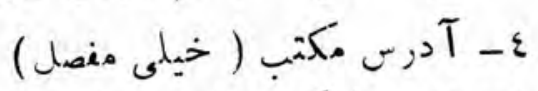

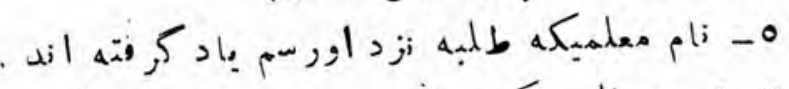

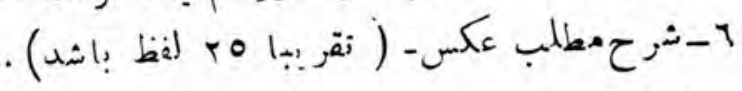

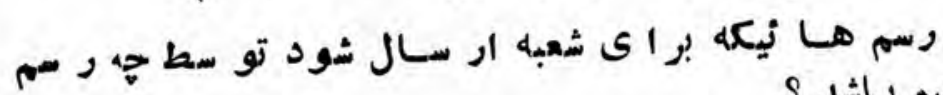

شده باثمد و

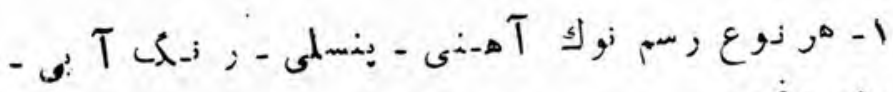

تبناشيرى وغيره 
$(1+r)$

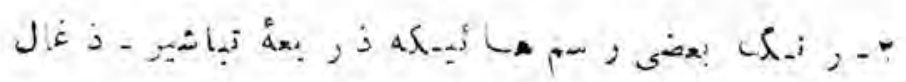

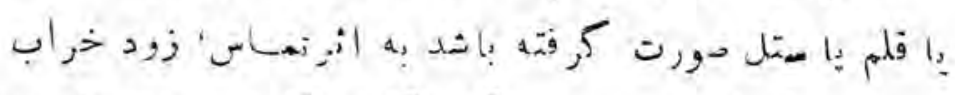

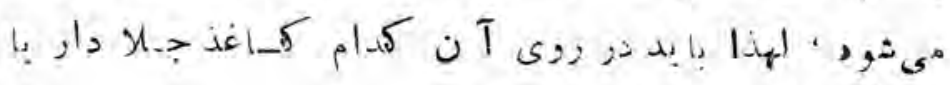

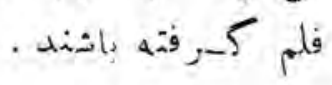

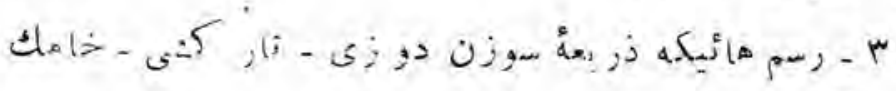

دوزى - 15

عكس ها هم قبول ميشود ياخير؟

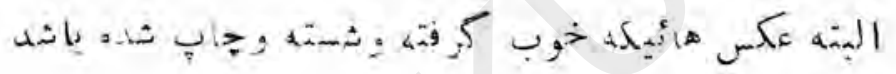

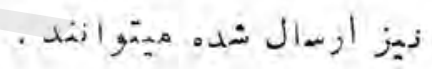

رسم هالدربارؤجه بـاشد

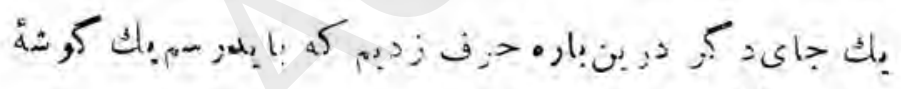

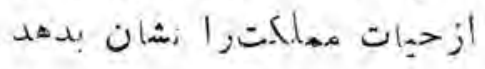

هe

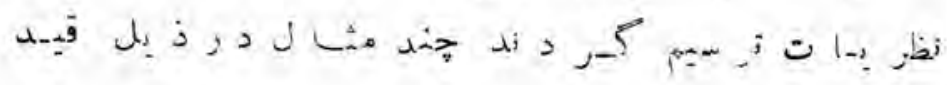

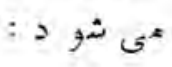

كأ

مان

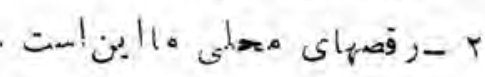


$(i r \wedge)$

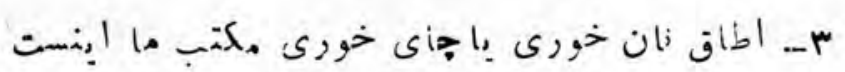

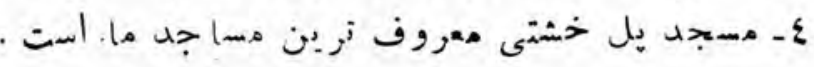

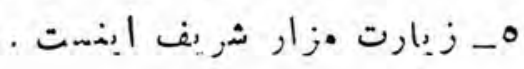

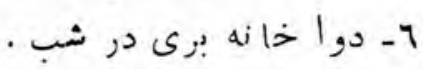

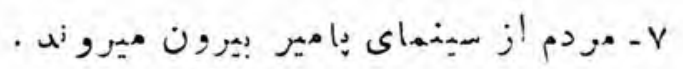

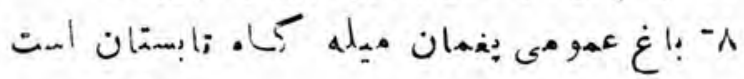

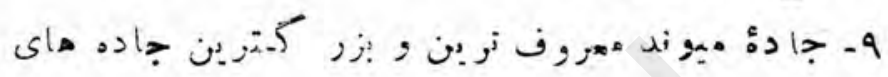

كانبل 1 ست

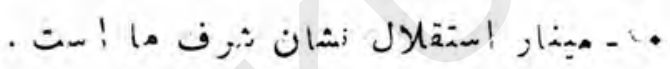

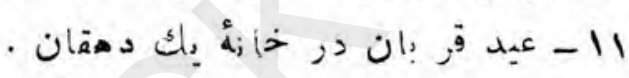

r

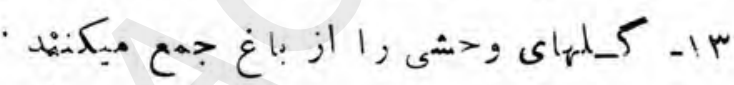

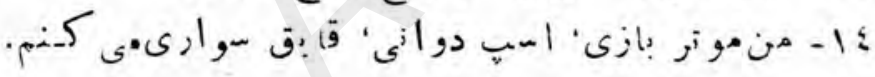

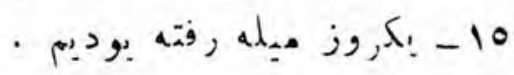

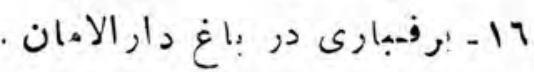

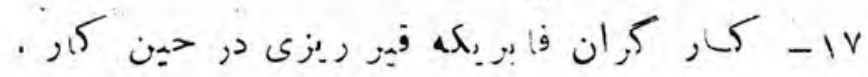

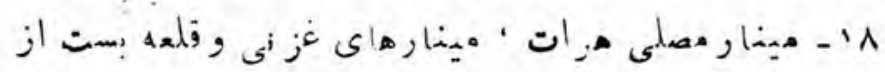

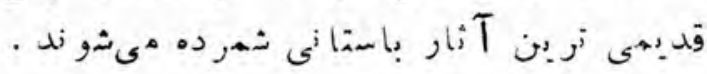

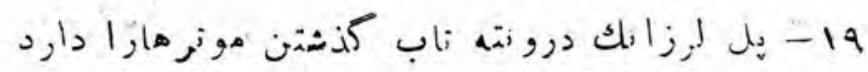

. 
$(1+9)$

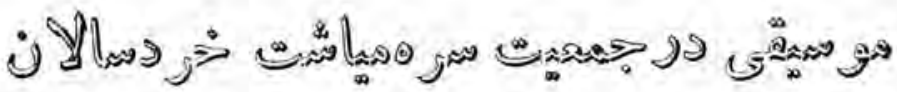

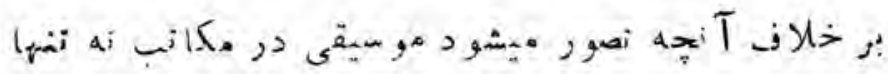

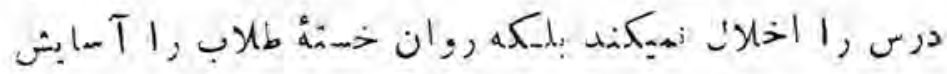

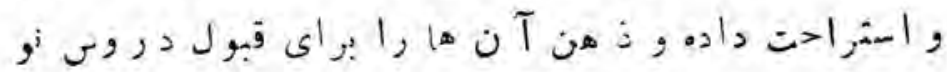

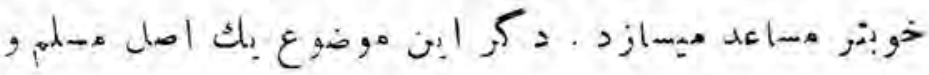

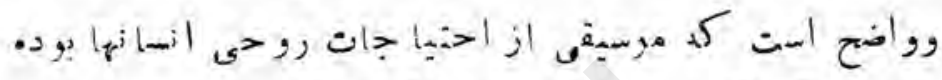

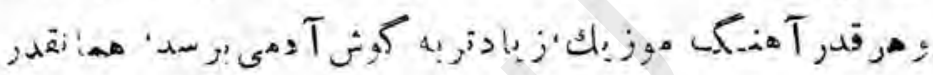

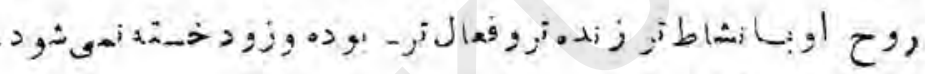

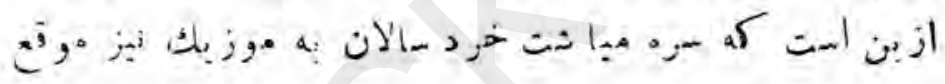
is ope مقصد اين برو متر ام جيست

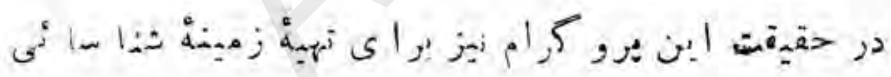

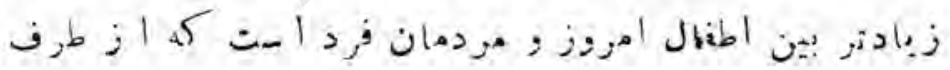

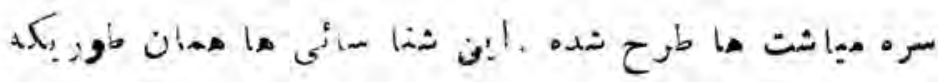

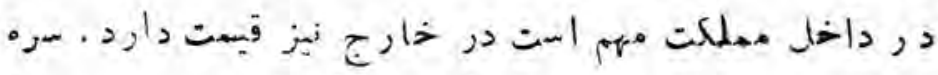

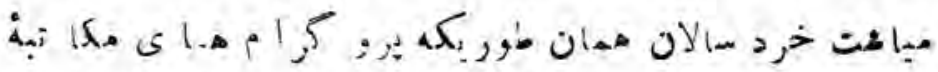

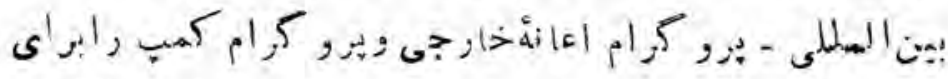

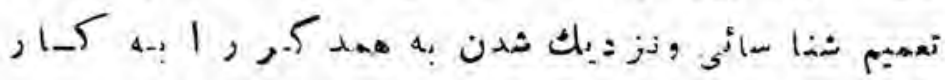


$(1+\cdot)$

مى اندازد به همانصورت برو كرام مرسجةى انيز به دورمقصد

:

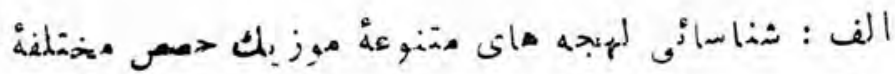

. Shlo

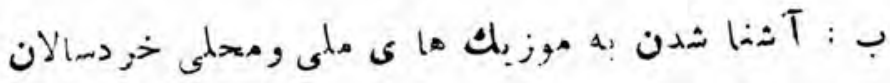

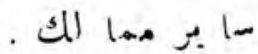

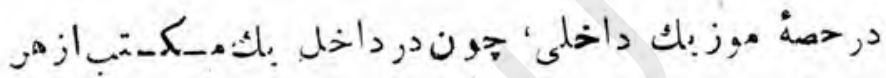

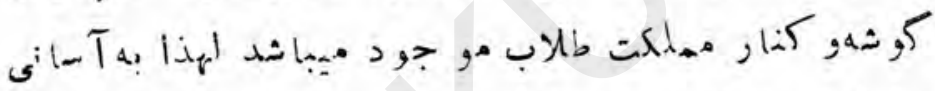

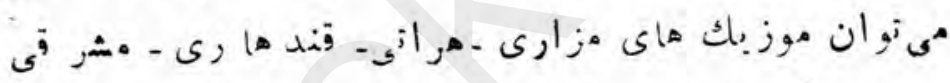

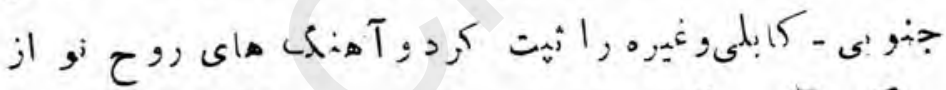

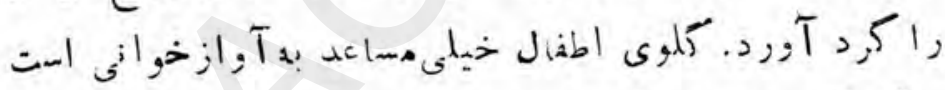

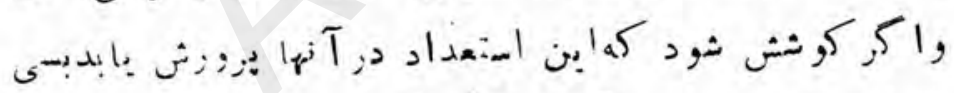

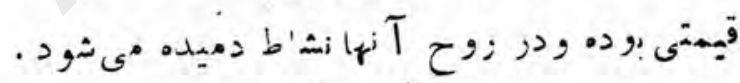

جطور مى تو انبه جمع آورى موزيكير داخت ؟

بهتر ين وآسان تر ين وسيله كماهروز بدست استعهارت

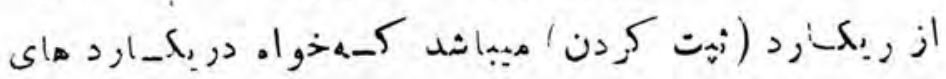

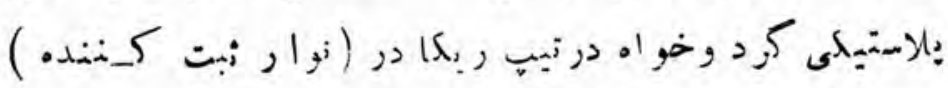

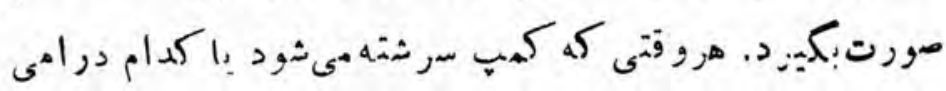


$(i n)$

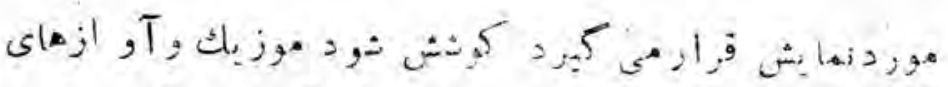

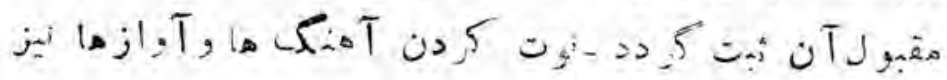

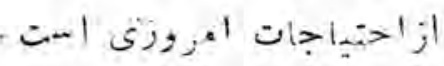

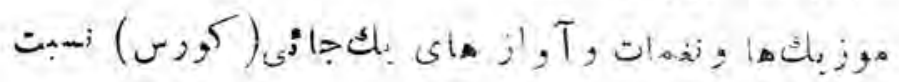

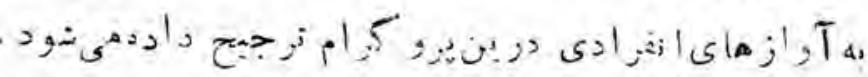

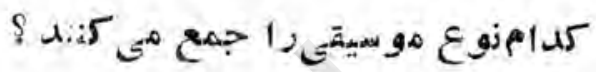

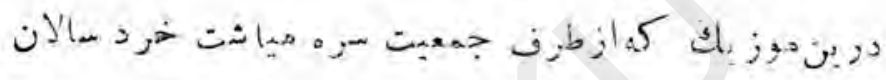

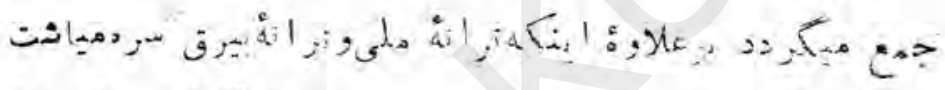

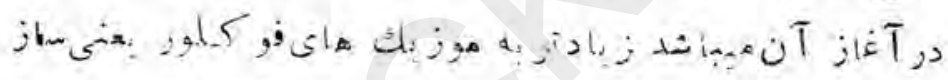

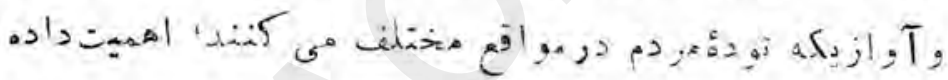

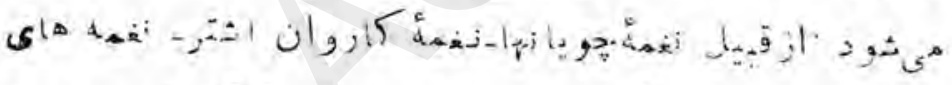

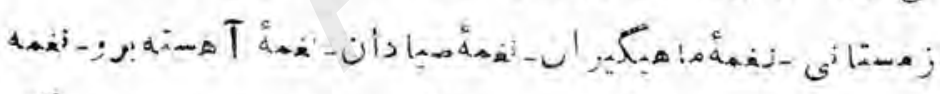

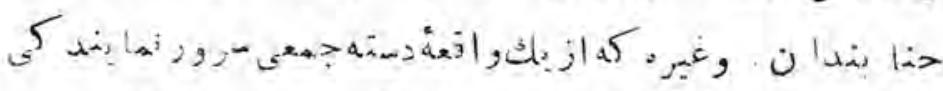

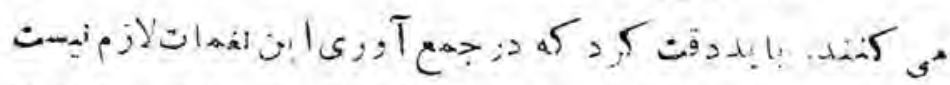

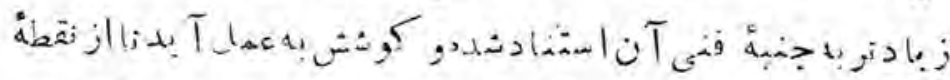

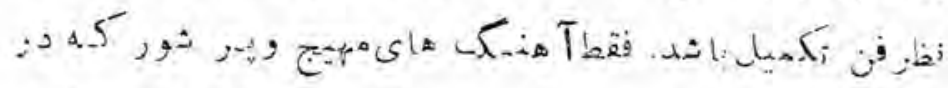

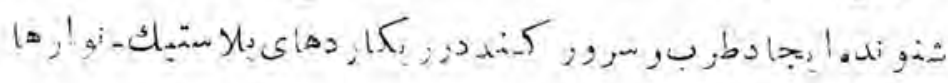

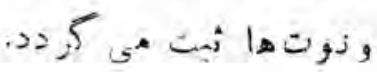


$(1+r)$

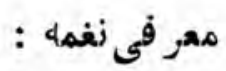

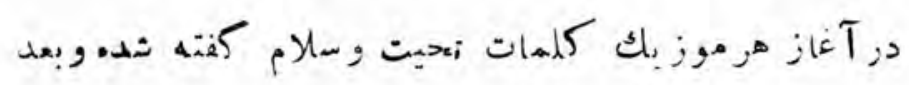

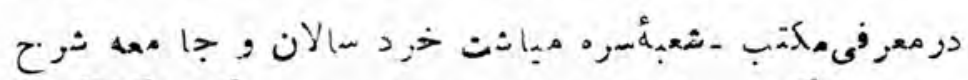

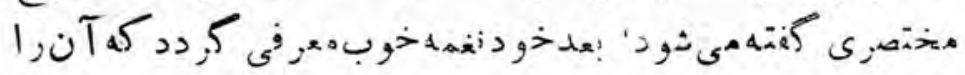

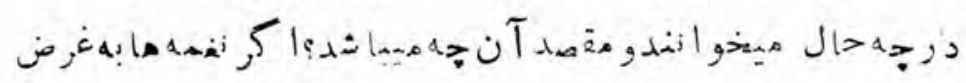

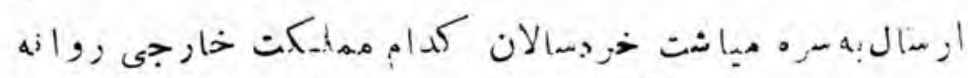

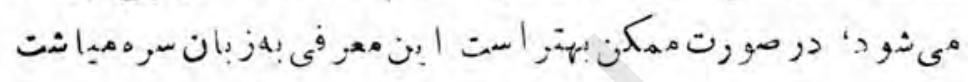

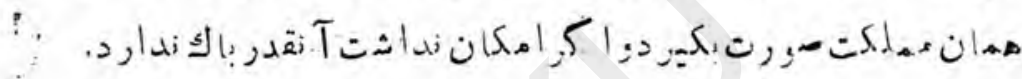

اختتاميه:

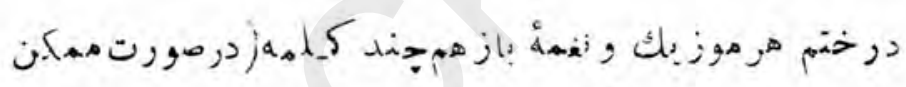

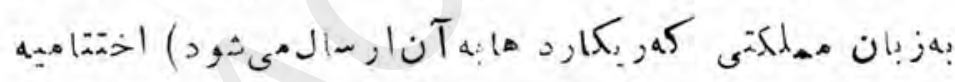

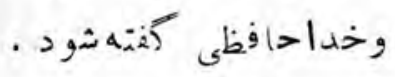

بـار بذدى:

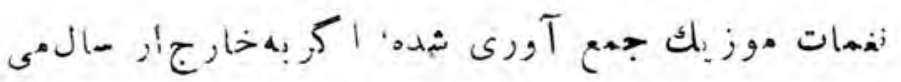

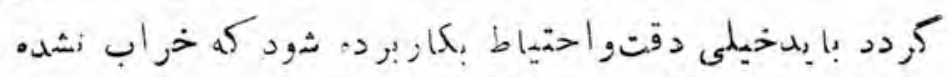

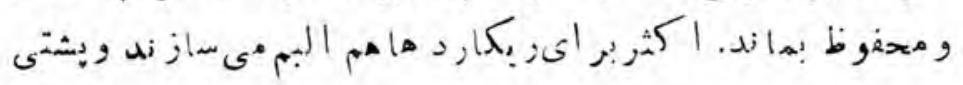

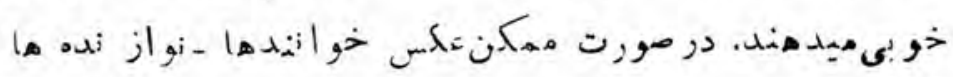

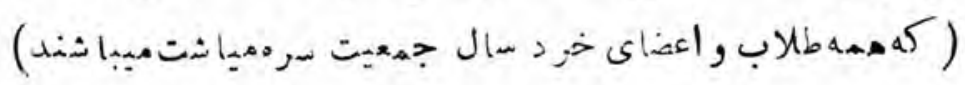




\section{$(1+r)$}

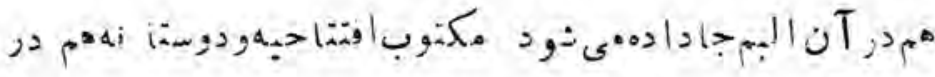
.

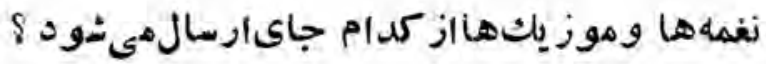

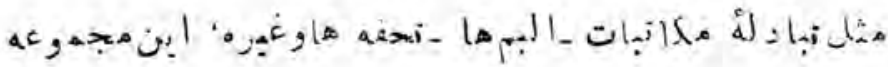

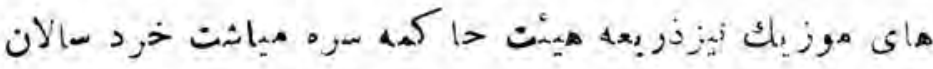

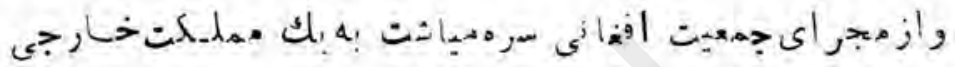

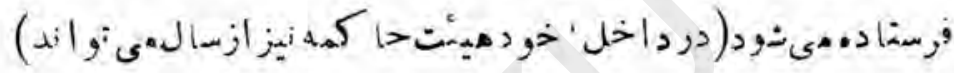

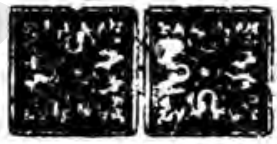




\section{$(1 r q)$}

ن لو

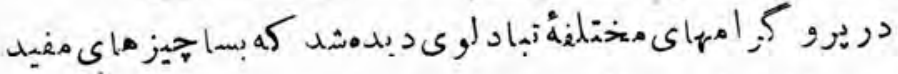

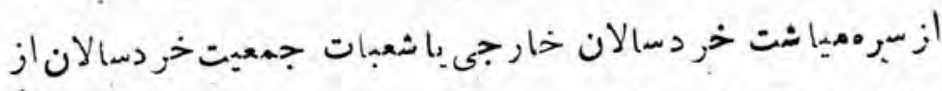

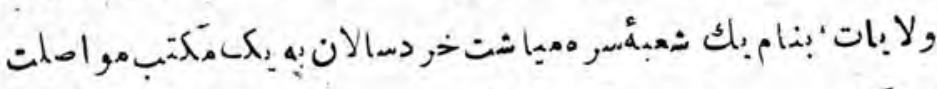

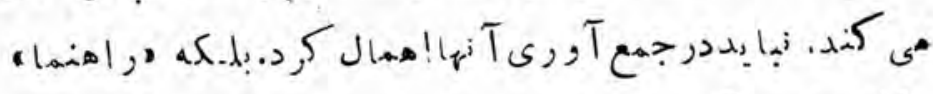

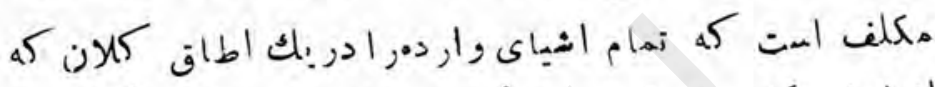

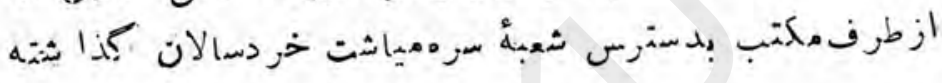

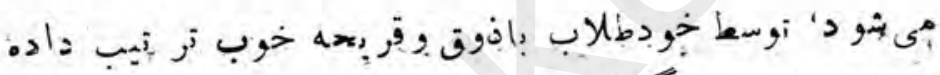

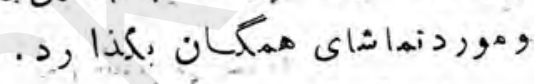

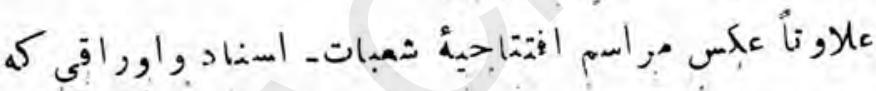

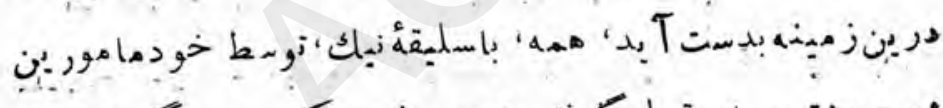

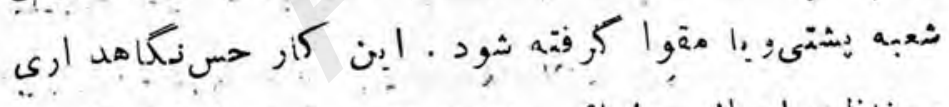

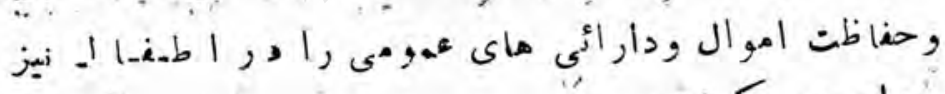

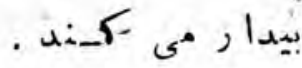

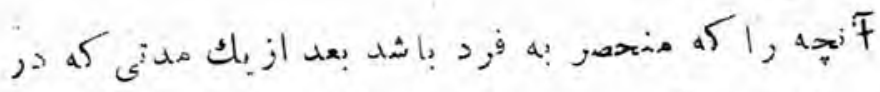

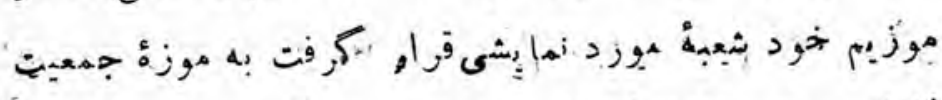

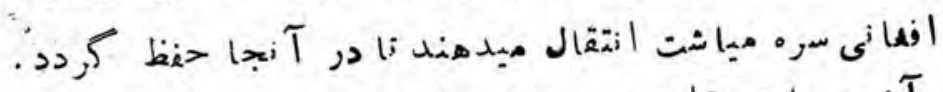

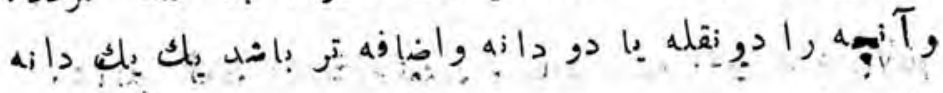

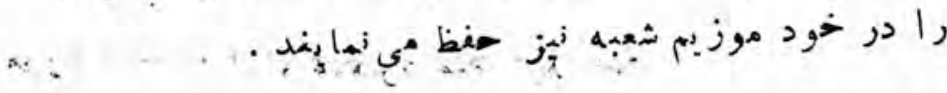


(iro)

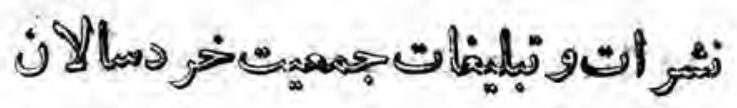

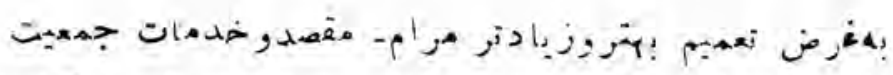

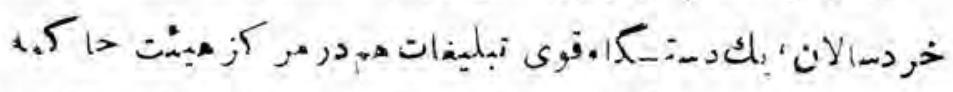

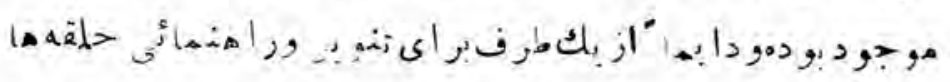

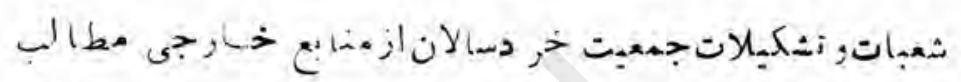

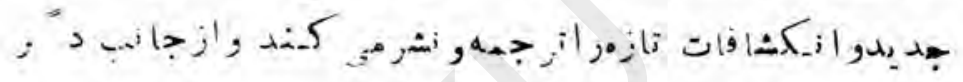

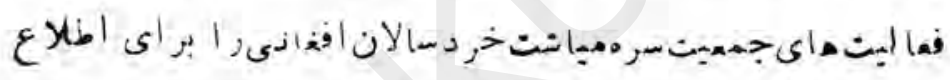

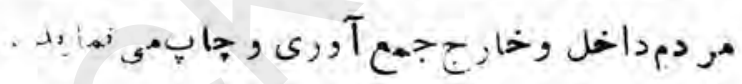

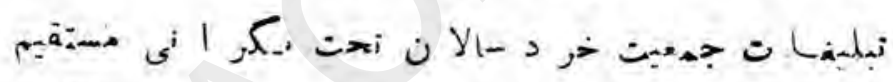

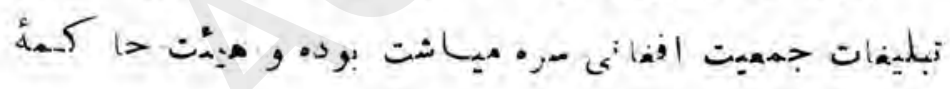

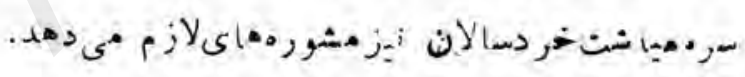

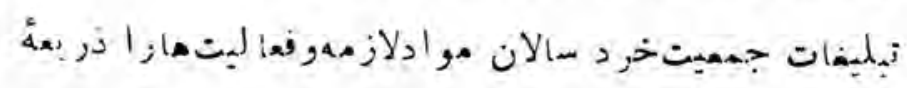

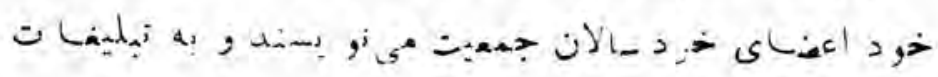

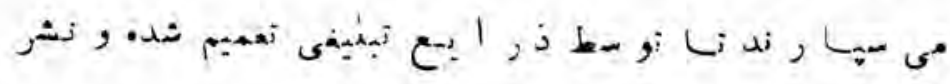
كرد .

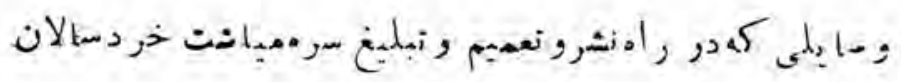

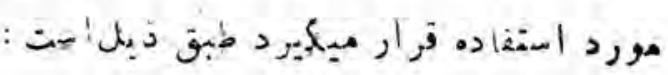


$(101)$

زثير ات:

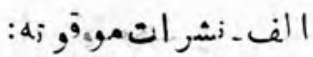

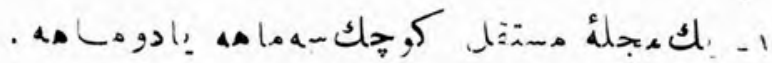

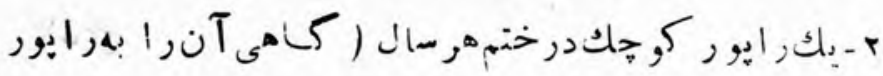

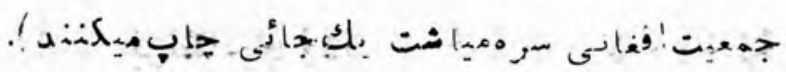

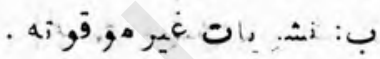

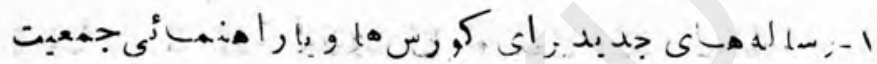
خر دسالان

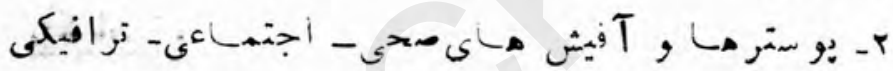

$\cdot \dot{\varepsilon}$

: كـبفر انئبهاومانوانل

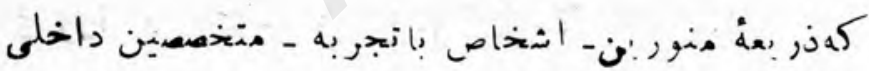
خا ر جى در موارد مر بوط به مرا م جمعيمت سرهميا: غث

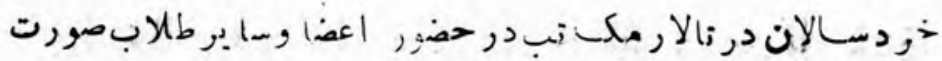

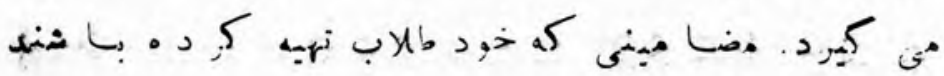

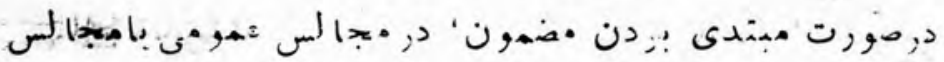

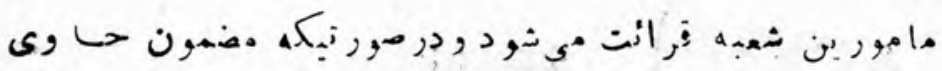

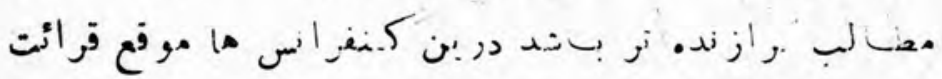




\section{(wiv)}

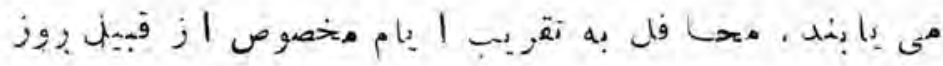

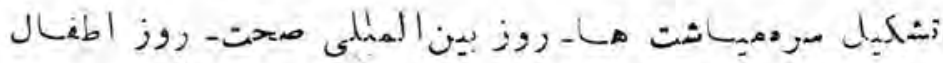
وغيره نرتيـ نور 2

\section{راديو:}

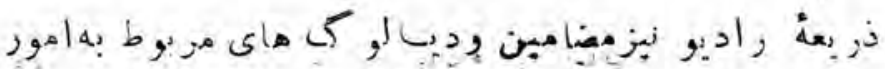

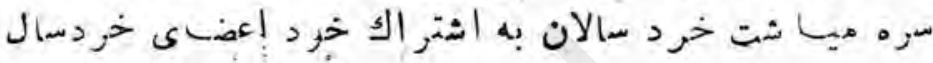

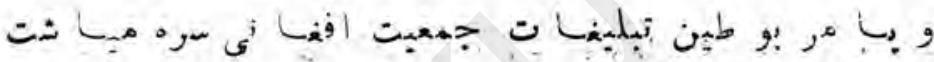

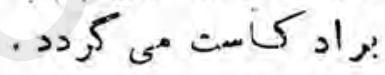

$|\lim \rangle$

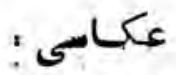

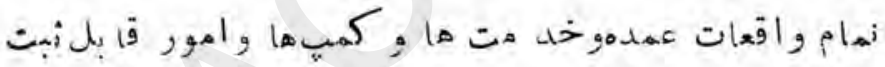

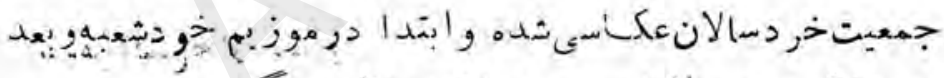

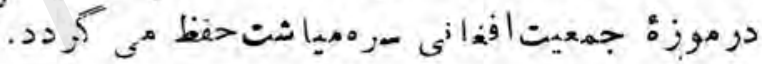

\section{وبسايلسمعىو بصري:}

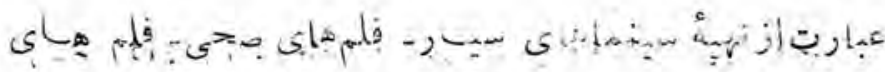

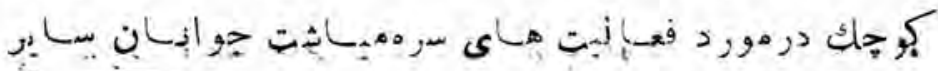
: 


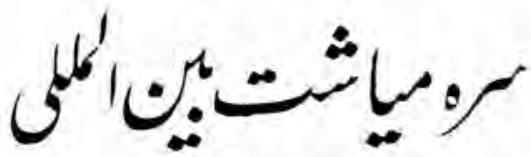

\section{家}

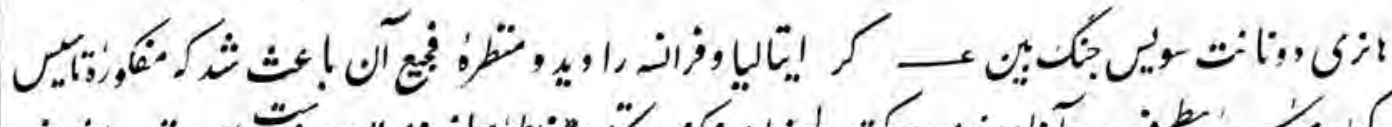

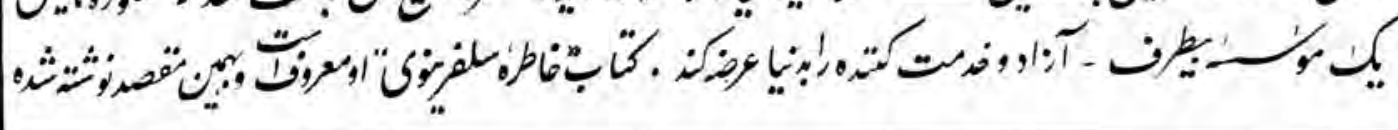

\section{$\downarrow$}

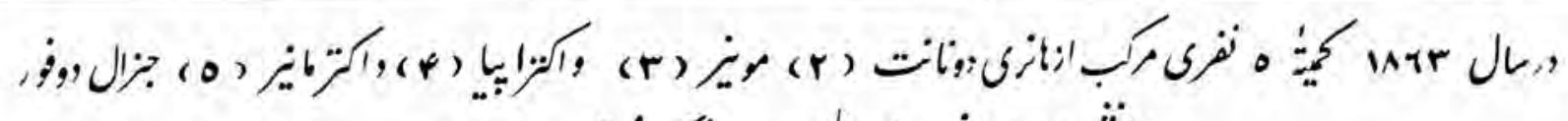

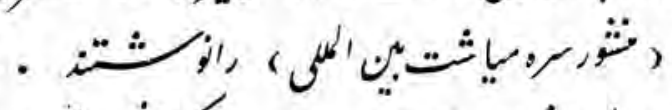

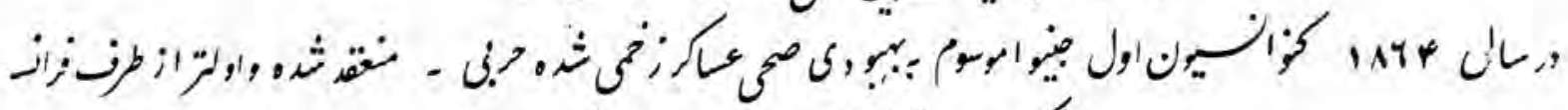

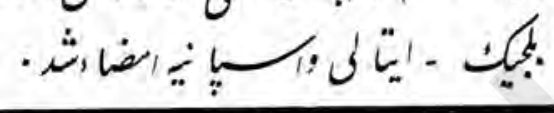

\section{$\downarrow$}

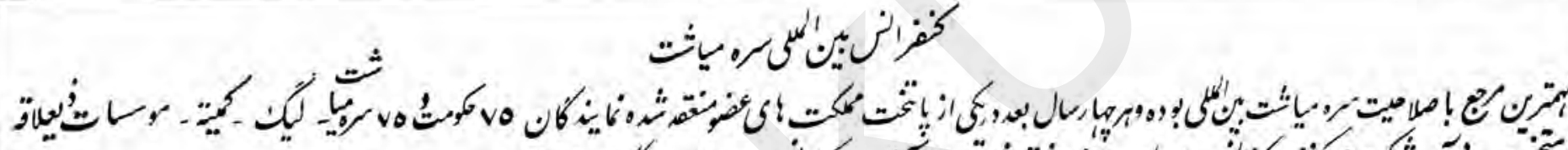

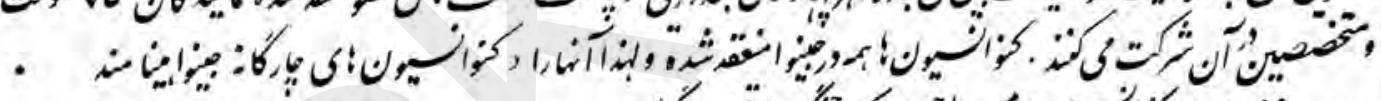

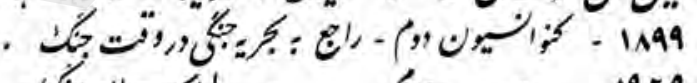

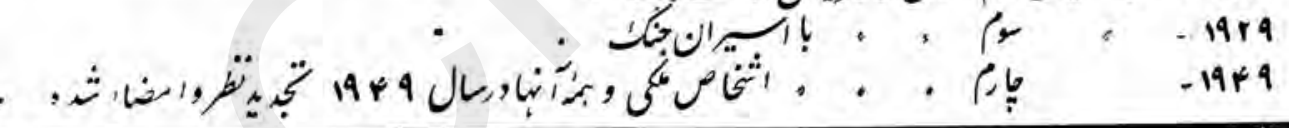

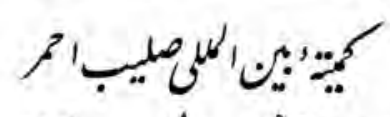

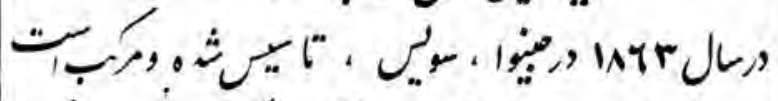

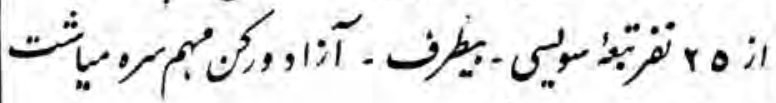

$$
\text { : }
$$

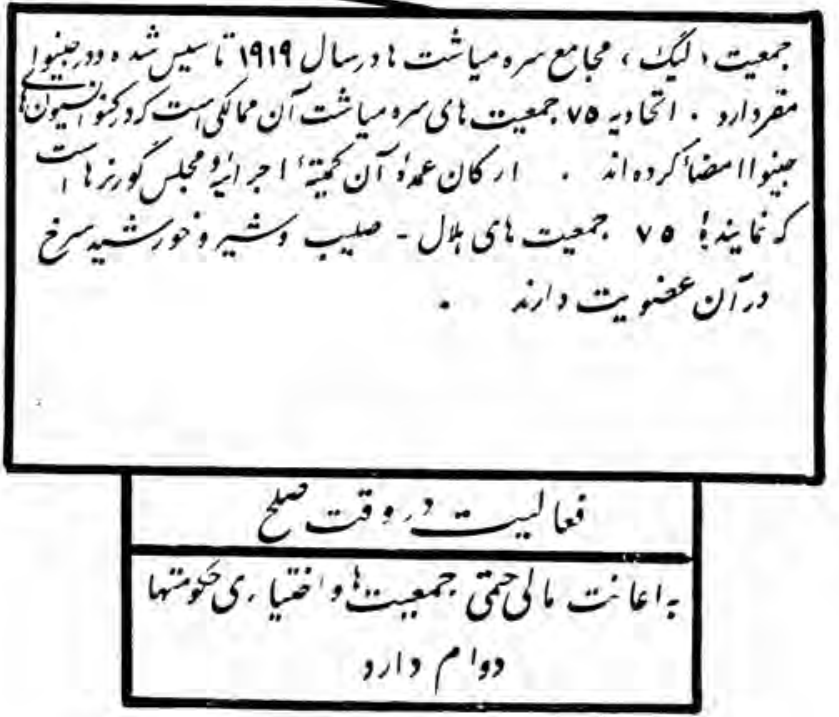




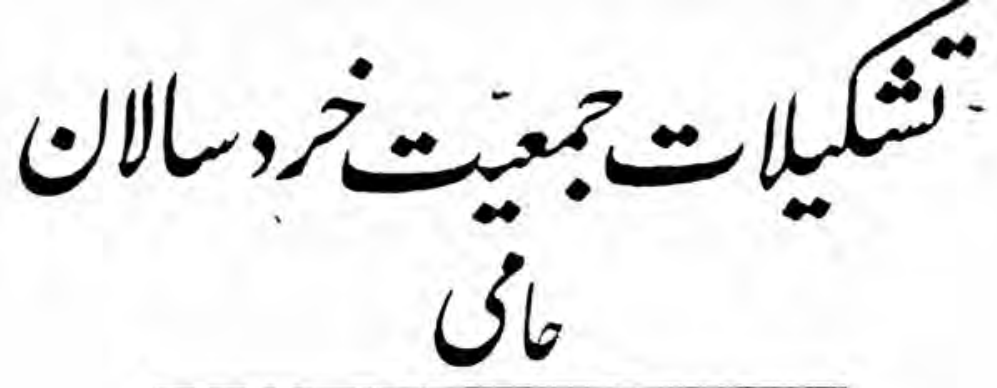
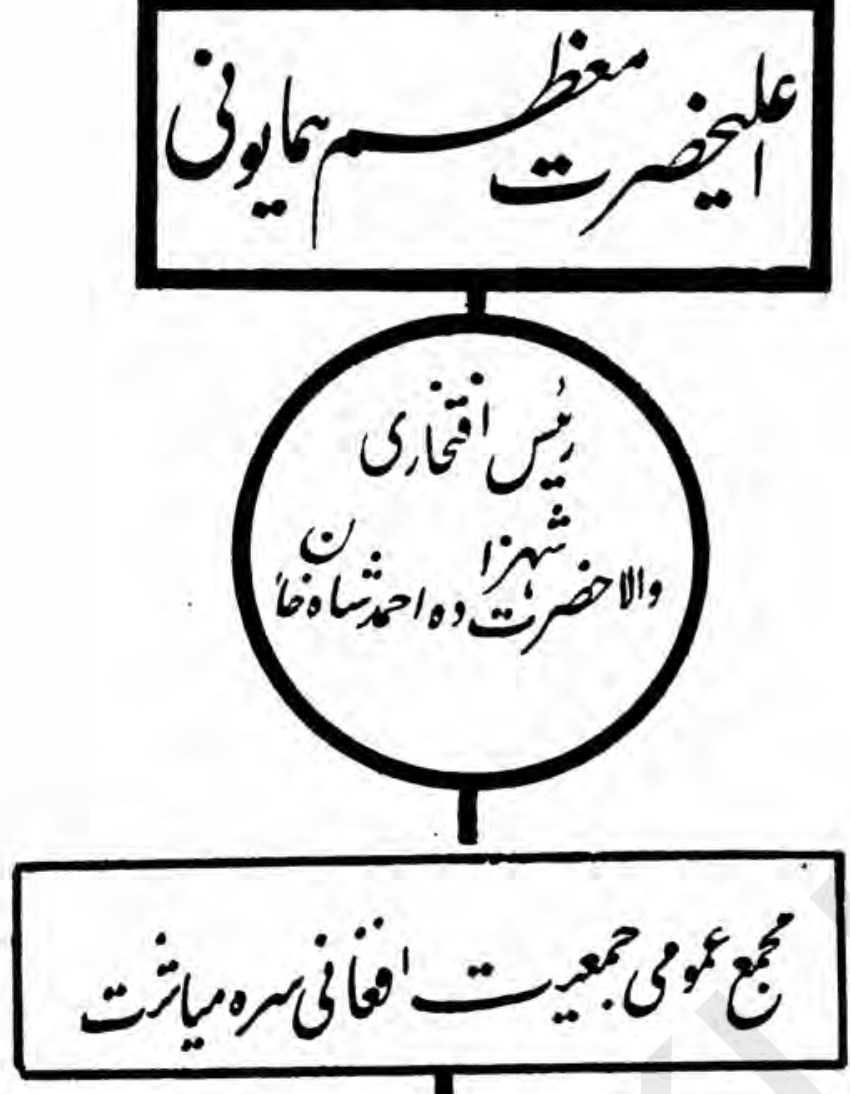

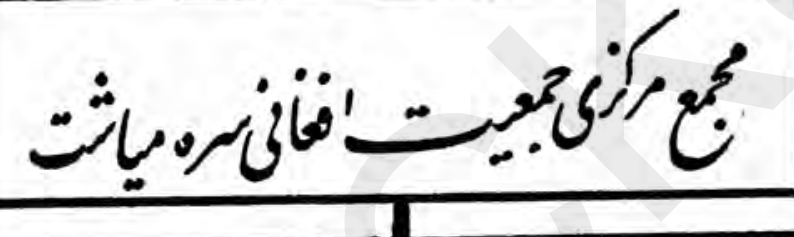

$$
\begin{aligned}
& \text { 每 } \\
& \text { كانت }
\end{aligned}
$$

بئت

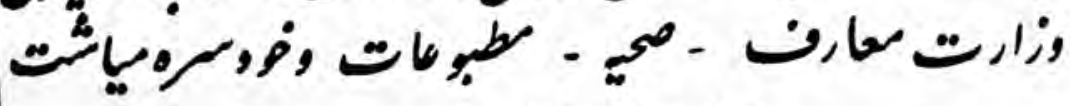

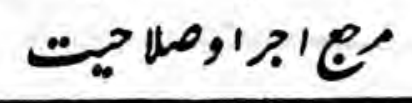
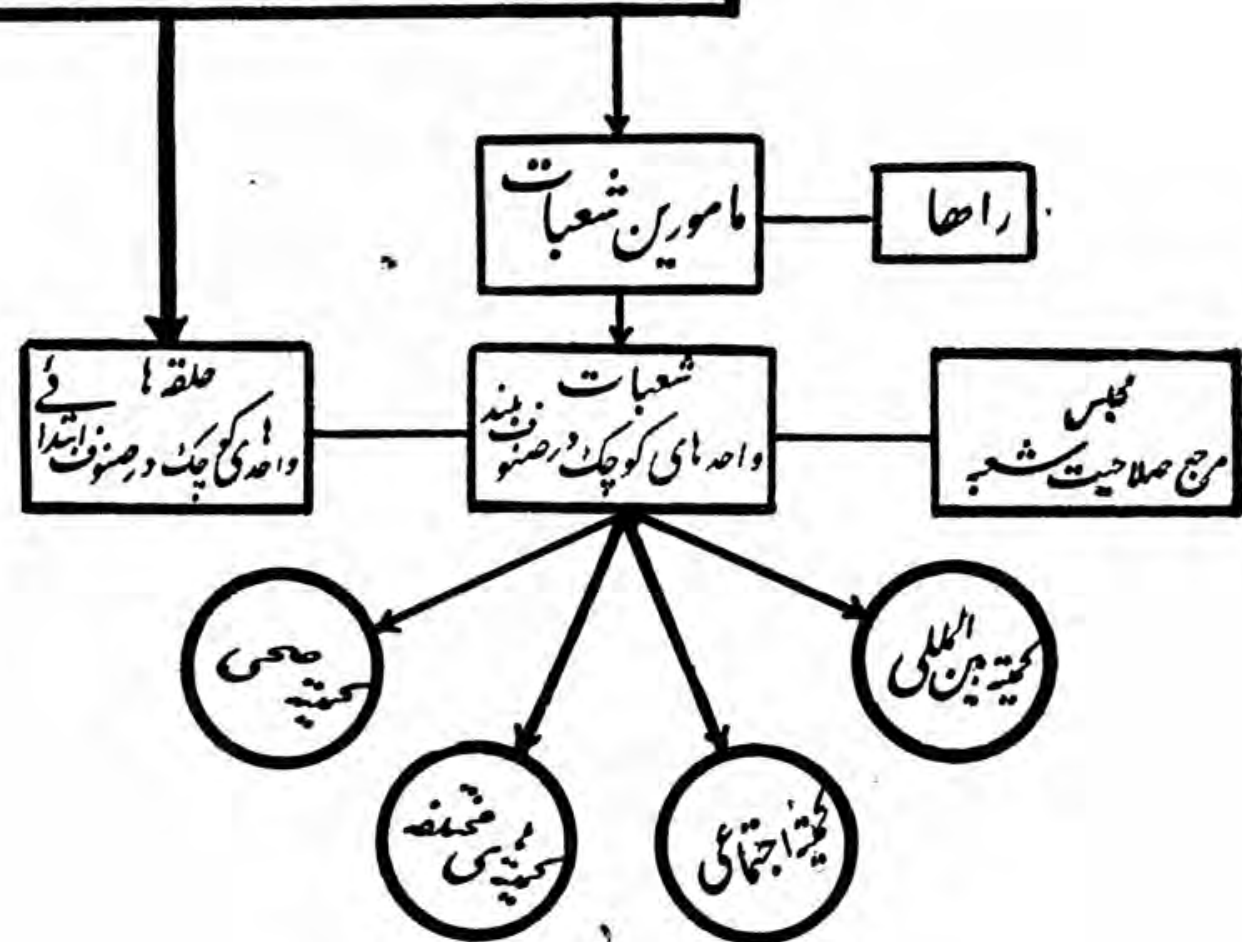


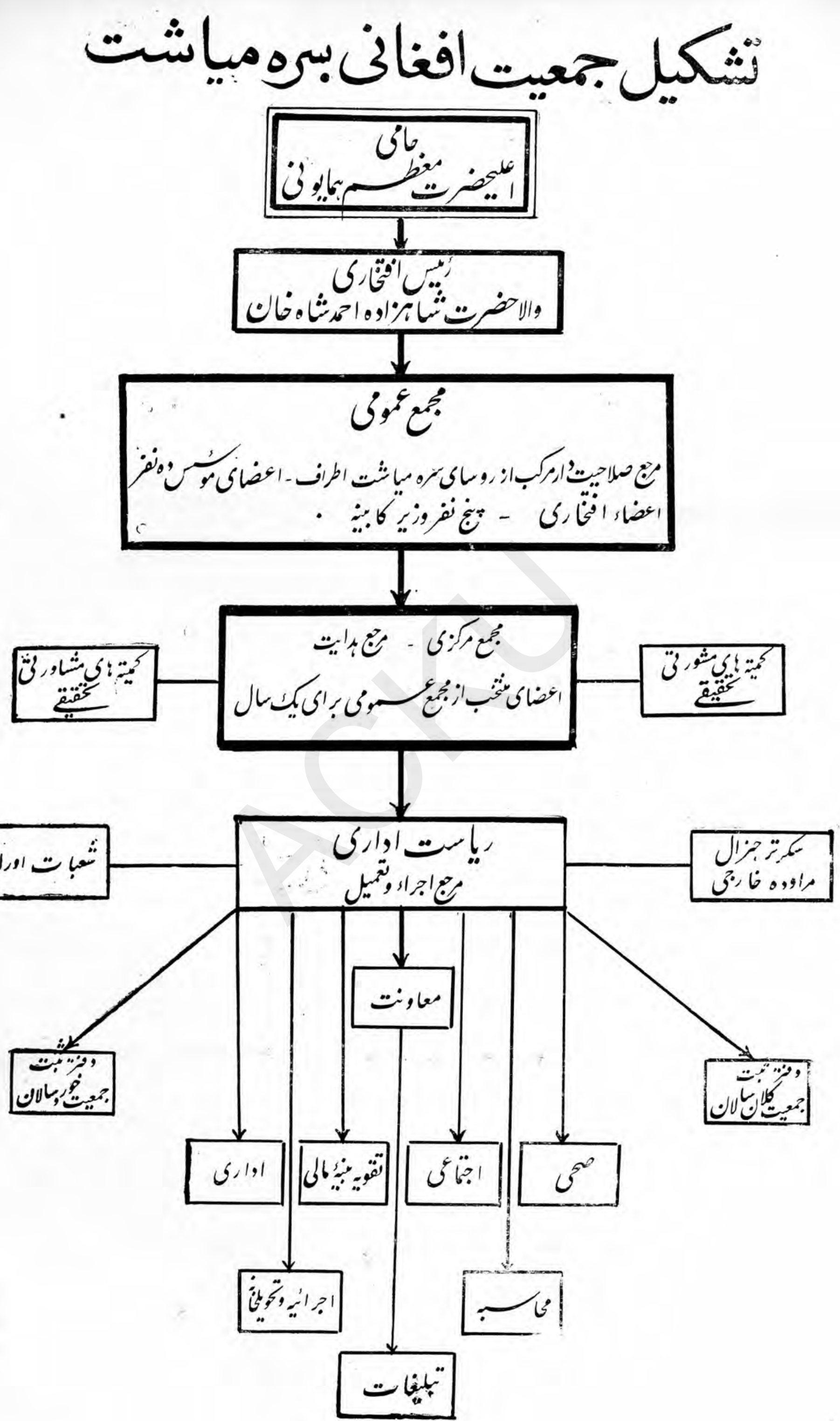




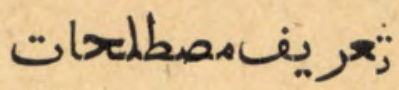

حركت - مراموتشكيلا ت آزاد و بيطرف مهلبب

سر• مبا شت :

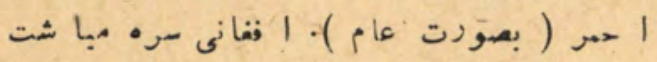

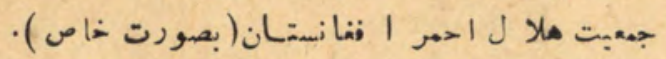

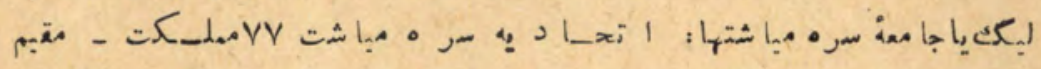

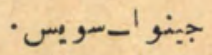

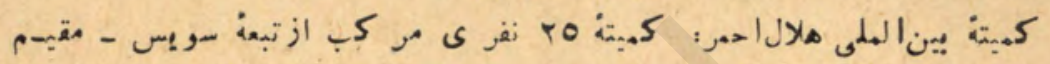

$$
\text { ج }
$$

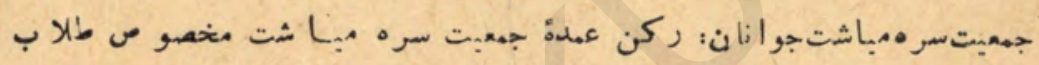

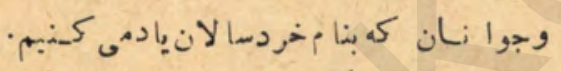

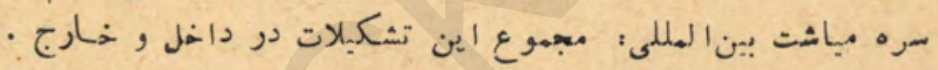

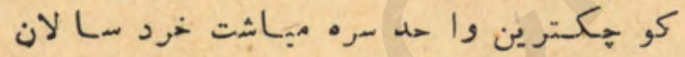

$:$ حal

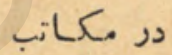

دستة بزرك سره مباشت خرد سالان دربكاتب.

: ش

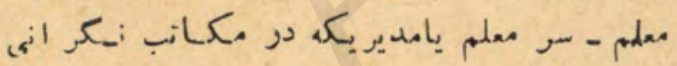

: Loids

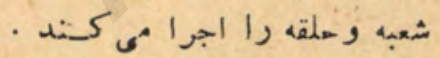

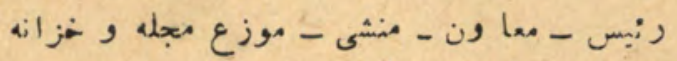

: مان مورين

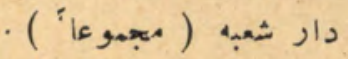

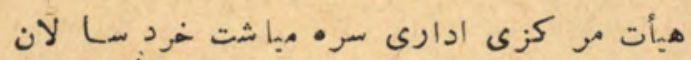

14.5 L $>$.

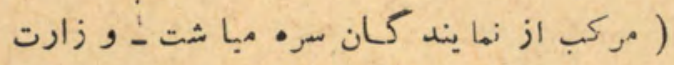

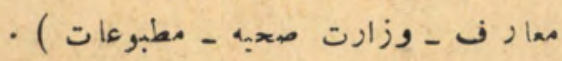

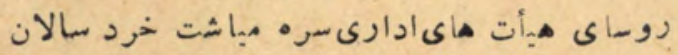

هبات مشاروتى :

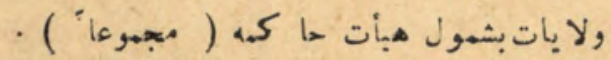




\section{GUIDE \\ TO}

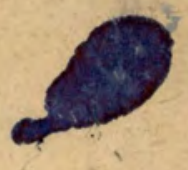

THE
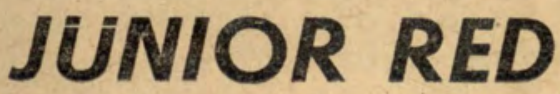

CRESCENT

BY

Ghulam Hazrat Koshan

Published by

Afghan

Red Crescent Society

- Government Printing House

Kabul, Afghanistan 